\title{
Article
}

\section{Mycosphere Notes 225-274: types and other specimens of some genera of Ascomycota}

Doilom $\mathbf{M}^{1,2,3}$, Hyde $\mathrm{KD}^{2,3,6}$, Phookamsak $\mathrm{R}^{1,2,3}$, Dai $\mathrm{DQ}^{4,}$, Tang $\mathrm{LZ}^{4,14}$, Hongsanan $\mathrm{S}^{5}$, Chomnunti $\mathrm{P}^{6}$, Boonmee $\mathrm{S}^{6}$, Dayarathne $\mathrm{MC}^{6}$, $\mathrm{Li} \mathrm{WJ}^{6}$, Thambugala $\mathrm{KM}^{6}$, Perera $\mathrm{RH}^{6}$, Daranagama $\mathrm{DA}^{6,13}$, Norphanphoun $\mathrm{C}^{6}$, Konta $\mathrm{S}^{6}$, Dong $\mathrm{W}^{6,7}$, Ertz $\mathrm{D}^{8,9}$, Phillips $\mathrm{AJL}^{10}$, McKenzie $\mathrm{EHC}^{11}$, Vinit $\mathrm{K}^{6,7}$, Ariyawansa $\mathrm{HA}^{12}$, Jones $\mathrm{EBG}^{7}$, Mortimer $\mathrm{PE}^{2}$, $\mathrm{Xu} \mathrm{JC}^{2,3}$, Promputtha $\mathrm{I}^{1}$

\footnotetext{
${ }^{1}$ Department of Biology, Faculty of Science, Chiang Mai University, Chiang Mai 50200, Thailand

${ }^{2}$ Key Laboratory for Plant Diversity and Biogeography of East Asia, Kunming Institute of Botany, Chinese Academy of Sciences, 132 Lanhei Road, Kunming 650201, China

${ }^{3}$ World Agro Forestry Centre, East and Central Asia, 132 Lanhei Road, Kunming 650201, Yunnan Province, People's Republic of China

${ }^{4}$ Center for Yunnan Plateau Biological Resources Protection and Utilization, College of Biological Resource and Food Engineering, Qujing Normal University, Qujing, Yunnan 655011, China

${ }^{5}$ Shenzhen Key Laboratory of Microbial Genetic Engineering, College of Life Sciences and Oceanography, Shenzhen University, Shenzhen 518060, China

${ }^{6}$ Center of Excellence in Fungal Research, Mae Fah Luang University, Chiang Rai 57100, Thailand

${ }^{7}$ Department of Entomology and Plant Pathology, Faculty of Agriculture, Chiang Mai University, Chiang Mai 50200, Thailand

${ }^{8}$ Department Research (BT), Botanic Garden Meise, Nieuwelaan 38, BE-1860 Meise, Belgium

${ }^{9}$ Direction Générale de l'Enseignement non obligatoire et de la Recherche scientifique, Fédération Wallonie-Bruxelles, Rue A. Lavallée 1, BE-1080 Bruxelles, Belgium

${ }^{10}$ Universidade de Lisboa, Faculdade de Ciências, Biosystems and Integrative Sciences Institute (BioISI), Campo Grande, 1749-016 Lisbon, Portugal

${ }^{11}$ Landcare Research Manaaki Whenua, Private Bag 92170, Auckland, New Zealand

12 Department of Plant Pathology and Microbiology, College of BioResources and Agriculture, National Taiwan University, No.1, Sec.4, Roosevelt Road, Taipei 106, Taiwan, ROC

${ }^{13}$ Department of Botany, University of Kelaniya, Kelaniya, Sri Lanka

${ }^{14}$ State Key Laboratory of Genetic Resources and Evolution, Kunming Institute of Zoology, Chinese Academy of Sciences, Kunming, Yunnan 650223, People's Republic of China
}

Doilom M, Hyde KD, Phookamsak R, Dai DQ, Tang LZ, Hongsanan S, Chomnunti P, Boonmee S, Dayarathne MC, Li WJ, Thambugala KM, Perera RH, Daranagama DA, Norphanphoun C, Konta S, Dong W, Ertz D, Phillips AJL, McKenzie EHC, Vinit K, Ariyawansa HA, Jones EBG, Mortimer PE, Xu JC, Promputtha I 2018 - Mycosphere Notes 225-274: types and other specimens of some genera of Ascomycota. Mycosphere 9(4), 647-754, Doi10.5943/mycosphere/9/4/3

\section{Abstract}

This is the fifth in a series, Mycosphere notes, wherein 50 notes are provided on types of genera and other specimens with descriptions and illustrations. This includes one genus in Arthoniomycetes, one genus in Eurotiomycetes, 38 genera in Dothideomycetes, six genera in Sordariomycetes, two genera in Ascomycota, families incertae sedis, one genus in Pezizomycotina, and one taxon, Angatia rondoniensis, is treated as a doubtful species. Pycnocarpon magnificum is classified in Asterinaceae. We reinstate Eopyrenula in Dacampiaceae on the basis of its 
morphological characters, which are similar to other members in this family. Eopyrenula leucoplaca is designated as a reference specimen. Fasciatispora arengae is described as a new species. The isotype specimen (GZU 000301526), which was formerly named as Thyridium concinnum is transferred to Platystomum based on morphology. Syrropeltis is placed in the family Parmulariaceae based on morphology. Rivilata and Vonarxella are excluded from Saccardiaceae, and treated in Phaeothecoidiellaceae and Schizothyriaceae, respectively. The family Saccardiaceae based on Saccardia quercina is maintained and includes Ascolectus, Cyanodiscus, Henningsiella, Phillipsiella, Pseudodiscus and Schenckiella. Johansoniaceae is introduced as a new family. We hope to motivate fresh collecting of type species included of taxa in genera incertae sedis, so that molecular data can be obtained to confirm their natural classification.

Key words - two new taxa - Asterinaceae - Astrosphaeriellaceae - Barbatosphaeriaceae Dacampiaceae - Davidiellaceae - Didymellaceae - Dothideomycetes - Didymosphaeriaceae Gloniaceae - Hysteriaceae - Johansoniaceae - Leptosphaeriaceae - Lindgomycetaceae Lophiostomataceae - Microtheliopsidaceae - Mytilinidiaceae - Myriangiales - Naetrocymbaceae - Parmulariaceae - Phaeothecoidiellaceae - Polycoccaceae - Roccellaceae - Saccardiaceae Schizothyriaceae - Sordariomycetes - Strangosporaceae - Testudinaceae - Venturiaceae Xylariales

\section{Table of contents}

The following list of taxa is a continuation from the fourth paper in the series Mycosphere notes (Hyde et al. 2018, 169-224), organized following the Outline of Ascomycetes (Wijayawardene et al. 2018) and the classification of some taxa is updated in this study.

Arthoniomycetes O.E. Erikss. \& Winka

Arthoniales Henssen ex D. Hawksw. \& O.E. Erikss.

Roccellaceae Chevall.

225. Mazosia phyllosema (Nyl.) Zahlbr., Cat. Lich. Univers. 2: 503 (1923) [1924]

Eurotiomycetes O.E. Erikss. \& Winka

Chaetothyriales M.E. Barr

Microtheliopsidaceae O.E. Erikss.

226. Microtheliopsis uleana Müll. Arg., Flora, Regensburg 73: 195 (1890)

Dothideomycetes O.E. Erikss. \& Winka

Asterinales M.E. Barr ex D. Hawksw. \& O.E. Erikss.

Asterinaceae Hansf.

227. Pycnocarpon magnificum (Syd., P. Syd. \& E.J. Butler) Theiss., Abh. K.K. Zool.Bot. Ges. Wien 7(3): 31 (1913)

Capnodiales Woron.

Cladosporiaceae Nann.

228. Cladosporium herbarum (Pers.) Link, Mag. Gesell. naturf. Freunde, Berlin 8: 37 (1816) [1815]

Johansoniaceae Doilom, Phookamsak \& K.D. Hyde, fam. nov.

229. Johansonia setosa (G. Winter) Sacc., Syll. fung. (Abellini) 8: 785 (1889)

Phaeothecoidiellaceae K.D. Hyde \& Hongsanan

230. Rivilata ius Kohlm., Volkm.-Kohlm. \& O.E. Erikss., Can. J. Bot. 76(3): 472 (1998) 
Schizothyriaceae Höhn. ex Trotter, Sacc., D. Sacc. \& Traverso [as 'Schizothyrieae']

231. Vonarxella dipterygis Bat., J.L. Bezerra \& Peres [as 'diptericis'], Riv. Patol. veg., Pavia, sér. 4 1(1-2): 62 (1965)

Gloniales Jayasiri \& K.D. Hyde

Gloniaceae E. Boehm, C.L. Schoch \& Spatafora

232. Glonium lineare (Fr.) De Not., G. bot. ital. 2(1.1): 594 (1846)

Hysteriales Lindau

Hysteriaceae Chevall.

233. Gloniopsis praelonga (Schwein.) Underw. \& Earle [as 'praelongum'], Bull. Alabama Agricultural Experiment Station 80: 196 (1897)

234. Hysterocarina paulistae H. Zogg, Ber. schweiz. bot. Ges. 59: 42 (1949)

235. Hysteroglonium ovatum (Cooke) Lindau, in Engler \& Prantl, Nat. Pflanzenfam., Teil. I (Leipzig) 1(1): 272 (1896)

236. Ostreichnion sassafras (Schwein.) M.E. Barr, Mycotaxon 3(1): 83 (1975)

Myriangiales, genus incertae sedis

237. Dictyonella erysiphoides (Rehm) Höhn. [as 'erisyphoides'], Sber. Akad. Wiss. Wien, Math.-naturw. Kl., Abt. 1 118: 369 [95 repr.] (1909)

Mytilinidiales E. Boehm, C.L. Schoch \& Spatafora

Mytilinidiaceae Kirschst.

238. Actidium hysterioides Fr., Observ. mycol. (Havniae) 2: 353 (1818)

239. Quasiconcha reticulata Barr \& Blackwell, Mycologia 72: 1224 (1980)

Pleosporales Luttrell ex M.E. Barr

Astrosphaeriellaceae Phook. \& K.D. Hyde

240. Mycopepon guianensis Boise, Syst. Ascom. 6(1): 168 (1987)

Dacampiaceae Körb.

241. Eopyrenula leucoplaca (Wallr.) R.C. Harris, Michigan Bot. 12(1): 19 (1973)

242. Pyrenidium actinellum Nyl., Flora, Regensburg 48: 210 (1865)

243. Pseudonitschkia parmotrematis Coppins \& S.Y. Kondr., Edinb. J. Bot. 52(2): 232 (1995)

Didymellaceae Gruyter, Aveskamp \& Verkley

244. Macroventuria anomochaeta Aa, Persoonia 6(3): 362 (1971)

245. Monascostroma innumerosum (Desm.) Höhn. [as 'innumerosa'], Annls mycol. 16(1/2): $160(1918)$

Didymosphaeriaceae Munk

246. Montagnula donacina (Niessl) Wanas., E.B.G. Jones \& K.D. Hyde, in Wanasinghe, Gareth Jones, Camporesi, Dissanayake, Kamolhan, Mortimer, Xu, Elsalam \& Hyde, Index Fungorum 319: 1 (2017)

Leptosphaeriaceae M.E. Barr

247. Chaetoplea dasylirii A.W. Ramaley [as 'dasylirionis'], Aliso 14(2): 151 (1995) 
Lindgomycetaceae K. Hiray., Kaz. Tanaka \& Shearer

248. Lindgomyces ingoldianus (Shearer \& K.D. Hyde) K. Hiray., Kaz. Tanaka \& Shearer, in Hirayama, Tanaka, Raja, Miller \& Shearer, Mycologia 102(3): 733 (2010)

Lophiostomataceae Sacc.

249. Platystomum concinnum (Petr.) Doilom \& K.D. Hyde, comb. Nov.

Roussoellaceae Jian K. Liu, Phookamsak, D.Q. Dai \& K.D. Hyde

250. Immotthia atroseptata (Piroz.) M.E. Barr, Mycotaxon 82: 383 (2002)

Testudinaceae Arx

251. Lepidosphaeria nicotiae Parg.-Leduc, Pubbl. Staz. Zool. Napoli, I 270: 2786 (1970)

252. Neotestudina rosatii Segretain \& Drestombes, C. r. hebd. Séane. Acad. Sci. Paris 253: 2579 (1961)

253. Ulospora bilgramii D. Hawksw., Malloch \& Sivan., Can. J. Bot. 57: 96 (1979)

Pleosporales, genus incertae sedis

254. Homostegia piggotii (Berk. \& Broome) P. Karst., Bidr. Känn. Finl. Nat. Folk 23: $222(1873)$

Venturiales Y. Zhang ter, C.L. Schoch \& K.D. Hyde

Venturiaceae E. Müll. \& Arx ex M.E. Barr

255. Venturia chlorospora (Ces.) P. Karst., Bidr. Känn. Finl. Nat. Folk 23: 189 (1873)

Trypetheliales Lücking, Aptroot \& Sipman

Polycoccaceae Ertz, Hafellner \& Diederich

256. Clypeococcum cladonema (Wedd.) D. Hawksw., Bot. J. Linn. Soc. 75(2): 197 (1977)

257. Polycoccum sauteri Körb., Parerga lichenol. (Breslau) 5: 470 (1865)

Dothideomycetes, families incertae sedis

Naetrocymbaceae Höhn. ex R.C. Harris

258. Jarxia thelenula (Müll. Arg.) D. Hawksw., Stud. Mycol. 31: 95 (1989)

259. Leptorhaphis epidermidis (Ach.) Th. Fr., Nova Acta R. Soc. Scient. upsal., Ser. 3 3: 373 (1861) [1860]

260. Tomasellia arthonioides (A. Massal.) A. Massal., Flora, Regensburg 39: 284 (1856)

Parmulariaceae E. Müll. \& Arx ex M.E. Barr

261. Syrropeltis xylopia Bat., J.L. Bezerra \& Matta, in Batista \& Bezerra, Portug. acta biol., Sér. B 7(4): 377 (1964)

Dothideomycetes, genera incertae sedis

262. Epibelonium gaeumannii E. Müll. [as 'gaeumanni'], Phytopath. Z. 47: 240 (1963)

263. Otthia spiraeae (Fuckel) Fuckel, Jb. nassau. Ver. Naturk. 23-24: 170 (1870) [186970]

264. Phycorella scytonematis Döbbeler, Sydowia 33: 33 (1980)

Sordariomycetes O.E. Erikss. \& Winka

Amphisphaeriales, genus incertae sedis

265. Fasciatispora arengae Konta \& K. D. Hyde, sp. nov. 
Diaporthomycetidae, family incertae sedis

Barbatosphaeriaceae H. Zhang, K.D. Hyde \& Maharachch.

266. Barbatosphaeria hippocrepida (Réblová) Réblová, Persoonia 35: 32 (2015)

Xylariales, genus incertae sedis

267. Diamantinia citrina A.N. Mill., Læssøe \& Huhndorf, Sydowia 55(1): 94 (2003)

\section{Sordariomycetes, genera incertae sedis}

268. Urupe guaduae Viégas, Bragantia 4(1-6): 125 (1944)

269. Phialemoniopsis ocularis (Gené \& Guarro) Perdomo, Dania García, Gené \& Guarro, Mycologia 105(2): 411 (2013)

270. Rhizophila marina K.D. Hyde \& E.B.G. Jones, Mycotaxon 34(2): 528 (1989)

\section{Ascomycota, families incertae sedis}

Saccardiaceae Höhn.

271. Saccardia quercina Cooke, Grevillea 7(no. 42): 49 (1878)

Strangosporaceae S. Stenroos, Miądl. \& Lutzoni

272. Strangospora moriformis (Ach.) Stein, in Cohn, Krypt.-Fl. Schlesien (Breslau) 2(2): 176 (1879)

\section{Pezizomycotina, genus incertae sedis}

273. Thelenidia monosporella Nyl., Flora, Regensburg 69: 463 (1886)

\section{Doubtful genus}

274. Angatia rondoniensis Bat., J.L. Bezerra \& Castr., Atas Inst. Micol. Univ. Recife 3: 65 (1966)

\section{Introduction}

The classification of fungi is of crucial importance as it improves our understanding of fungal relationships. A higher-level phylogenetic classification of the kingdom Fungi was proposed by Hibbett et al. (2007), while outlines of Ascomycota were compiled by Lumbsch \& Huhndorf (2007, 2010) and Wijayawardene et al. (2018). Hyde et al. (2013) provided comprehensive descriptions, illustrations and notes of families of Dothideomycetes with notes of the sexual and asexual morphs of their type genera. Liu et al. (2017) provided an updated classification for Dothideomycetes based on phylogenetic analyses and divergence times from an evolutionary clock. The family level classification of Sordariomycetes was carried out by Maharachchikumbura et al. (2016). Hongsanan et al. (2017a) provided an updated classification of accepted subclasses and orders of Sordariomycetes based on phylogenetic and molecular clock evidence. Lücking et al. (2016) presented a recent classification of lichenized fungi in the Ascomycota and Basidiomycota. An outline of discomycete families was offered by Ekanayaka et al. (2017).

Wijayawardene et al. (2018) provided a current classification of Ascomycota with generic placements, although over 230 genera were listed in Dothideomycetes as genera incertae sedis and 130 in Sordariomycetes as genera incertae sedis. Many of these genera are poorly known and their classification needs to be revisited. The names lack detailed descriptions and many also lack illustrations or their illustrations are basic and, therefore, type material of these species needs to be re-examined and suitably illustrated (Dayarathne et al. 2016).

This is the fifth contribution in a series of papers where we collaborate with mycologists to put together a set of notes of 50 taxa of fungi. Most of the taxa with notes herein, are poorly known, lack cultures and there is no sequence data in GenBank. Thus, we re-examined and provide descriptions, illustrations and notes from type specimens and other specimens. This basic data can be used as a foundation to facilitate their identification in future collections, and may result in fresh 
collections, epitypifications or designation of reference specimens, and generation of DNA sequence data. In this way the natural relationships of these taxa can be established.

\section{Materials \& Methods}

\section{Examination of herbarium material}

The type and other specimens were borrowed from the collections of Botanischer Garten und Botanisches Museum Berlin-Dahlem, Zentraleinrichtung der Freien Universität Berlin (B), The Natural History Museum (BM), US National Fungus Collections, USDA-ARS (BPI), Westerdijk Fungal Biodiversity Institute (CBS), Agriculture and Agri-Food Canada (DAOM), Farlow Reference Library and Herbarium of Cryptogamic Botany in Harvard University (FH), Conservatoire et Jardin botaniques de la Ville de Genève (G), Karl-Franzens-Universität Graz (GZU), University of Helsinki (H), Instituto Agronômico de Campinas (IAC), Illinois Natural History Survey, Illinois Department of Natural Resources (ILLS), University of North Carolina at Chapel Hill (IMS), Kew Royal Botanic Gardens (K \& IMI), Naturalis (L), Botanische Staatssammlung München (M), Mae Fah Luang University (MFLU), New York Botanical Garden (NY), Manaaki Whenua Landcare Research (PDD), Swedish Museum of Natural History (S), Universidade Federal de Pernambuco (URM) and Eidgenössische Technische Hochschule Zürich (ZT).

Fungal structures on the host substrates were observed with a stereo microscope (Motic SMZ168) and photographed with a ZEISS AxioCam ERc 5s attached to a Zeiss discovery v8 stereomicroscope (Carl Zeiss, Jena, Germany). Ascomata were first rehydrated in $5 \% \mathrm{KOH}$. Sections were cut by hand with a razor blade. Fine forceps were then used to remove sectioned ascomata and mounted in water. Cotton blue was added to water mounts to observe wall characteristics of fungal structure. Materials mounted in water were examined using a Nikon ECLIPSE 80i light microscope and images recorded with a Canon 550D digital camera. Photomicrographs were processed with Adobe Photoshop CS6 Extended version 10.0 (Adobe Systems, USA). Measurements were made using Tarosoft (R) Image Frame Work. Faces of fungi numbers and Index Fungorum numbers were obtained as detailed in Jayasiri et al. (2015) and Index Fungorum (2018).

\section{Results}

\section{Taxonomy}

We follow the outline of the Ascomycetes by Wijayawardene et al. (2018) for the arrangement of Ascomycota below.

Arthoniomycetes O.E. Erikss. \& Winka, Myconet 1(1): 4 (1997)

Arthoniales Henssen ex D. Hawksw. \& O.E. Erikss., Syst. Ascom. 5(1): 177 (1986)

Roccellaceae Chevall. [as 'Rocellaceae'], Fl. gén. env. Paris (Paris) 1: 604 (1826)

The family Roccellaceae belongs to the order Arthoniales, class Arthoniomycetes (Lücking et al. 2016, Wijayawardene et al. 2018) and represents a complex and diverse assemblage of species, including crustose to fruticose lichens, as well as lichenicolous fungi (Ertz et al. 2014a) and large conspicuous fruticose lichen-forming fungi (Tehler et al. 2007, 2010). Most species of Roccellaceae are common in subtropical coastal habitats (Tehler 1990, Follmann \& Werner 2003, Aptroot \& Sparrius 2008). The phylogenies in the family Roccellaceae have mainly been presented in the studies of Tehler et al. (2004, 2009), Tehler \& Irestedt (2013) and Ertz et al. (2014b, 2015b) who together provided a large-scale, phylogenetic revision of the family and added eight new genera. Currently, 40 genera are accepted in the family Roccellaceae (Lücking et al. 2016, Wijayawardene et al. 2018). Short notes on these genera were provided by Wijayawardene et al. (2017a). 
Mazosia A. Massal., Geneac. lich. (Verona): 9 (1854)

= Chiodecton subgen. Rotularia Vain., Ann. Acad. Sci. fenn., Ser. A 15(no. 6): 290 (1921)

= Gomphospora A. Massal., Ric. auton. lich. crost. (Verona): 40 (1852)

= Gymnographoidea Fink, in Hedrick, Mycologia 22(5): 249 (1930)

= Micrographina Fink, in Hedrick, Mycologia 22(5): 250 (1930)

= Opegrapha sect. Rotula Müll. Arg., Flora, Regensburg 66(22): 348 (1883)

= Rotula (Müll. Arg.) Müll. Arg., Lich. Epiph. Novi: 19 (1890)

= Rotularia (Vain.) Zahlbr., Cat. Lich. Univers. 2: 470 (1923) [1924]

Lichenized on leaves, branches and twigs, or lichenicolous. Thallus crustose, continuous or dispersed, ecorticate with thin layer of irregular hyphae of different thickness above algal layer, smooth to verrucose-rugose and/or pilose (Lücking 2008). Photobiont trentepohlioid. Sexual morph: Ascomata apothecioid, immersed-erumpent, solitary or gregarious, rounded, disc greyish black to black; margin zeorine, innermost part often white, same color as thallus (Lücking 2008). Excipulum formed by inclinate layer of parallel hyphae, dark brown to blackish brown, $\mathrm{K}+$ black, externally covered by layer of colorless to grey crystals ('crystallostratum') above which is thin, thallus layer dominated by photobiont and with thin layer of colorless hyphae above (Lücking 2008). Hypothecium composed of thin layer of periclinal hyphae (ascogenous hyphae) below and thicker layer of irregularly prosoplectenchymatous hyphae above, colorless to pale yellowish or greenish brown, I+ faintly blue then quickly orange-yellow, KI- (Lücking 2008). Epithecium indistinct but paraphyses prolong above asci and forming rather thick, epithecioid layer (Lücking 2008). Hymenium colorless, I+ yellow then quickly orange-red, KI+ for a long time blue, then aeruginous, and finally yellow (Lücking 2008). Hamathecium of numerous, hypha-like, branched, hyaline, septate, anastomosed paraphyses, embedded in a gelatinous matrix. Asci 8-spored, bitunicate, fissitunicate, clavate to oblong. Ascospores fusiform, transversely septate, hyaline, thick-walled. Asexual morph: (see Lücking 2008).

Type species - Mazosia rotula (Mont.) A. Massal.

Notes - Mazosia was established by Massalongo (1854) with M. rotula (Mont.) A. Massal. as the type species. Most Mazosia species are obligately foliicolous and occur abundantly on living leaves, some occurring on bark, and others on smooth substrates, such as paint or plastic (Sparrius 2004, Aptroot et al. 2014, Sakata et al. 2017). Aptroot et al. (2014) provided a key to all 13 of the species of Mazosia with 3-septate ascospores from both foliicolous and corticolous habits. Sakata et al. (2017) described two corticolous Mazosia species from Japan and also provided a key to the corticolous species. We described and illustrated a specimen of M. phyllosema (URM 38670) and found that ascospores are longer (25-39 versus 11-12 $\mu \mathrm{m}$ long) than in the description in Nylander (1873), and longer than M. phyllosema (15-25 $\mu \mathrm{m}$ long) in the key by Aptroot et al. (2014) and Lücking (2008). The specimen (URM 38670) is obviously different in ascospore dimensions from previous studies.

Mazosia phyllosema (Nyl.) Zahlbr., Cat. Lich. Univers. 2: 503 (1923) [1924]

Fig. 1

三Platygrapha phyllosema Nyl., Bull. Soc. linn. Normandie, sér. 2 7: 171 (1873)

Index Fungorum number: IF395118; Facesoffungi number: FoF04615

Lichenized on leaves. Thallus continuous, thin, smooth, pale greenish grey to pale green. Photobiont not observed. Sexual morph: Ascomata superficial, solitary or gregarious, circular, black, dome-like, scattered, flattened, globose. Excipulum not observed. Hypothecium not observed. Epithecium not observed. Hamathecium comprising numerous, 2-3.5 $\mu \mathrm{m}$ diam., branched, anastomosed, filiform, hypha-like, septate paraphyses, embedded in a gelatinous matrix. Asci 58$75 \times 12-18 \mu \mathrm{m}(\bar{x}=65 \times 15 \mu \mathrm{m}, \mathrm{n}=20)$, bitunicate, fissitunicate, 8 -spored, cylindrical-subclavate, sessile. Ascospores 25-39 $\times 5-7 \mu \mathrm{m}(\bar{x}=32 \times 6 \mu \mathrm{m}, \mathrm{n}=30)$, subfusiform, 3-septate, swollen at second celled, hyaline, tapering towards rounded apex, smooth-walled, slightly constricted at the septa. Asexual morph: Undetermined.

Material examined - BRAZIL, Perfil AR-4., Porto Velho, Rondônia, on leaves of Orbignya martiana Barb. Rodr. (Arecaceae), 1962, O. Fonseca (URM 38670). 


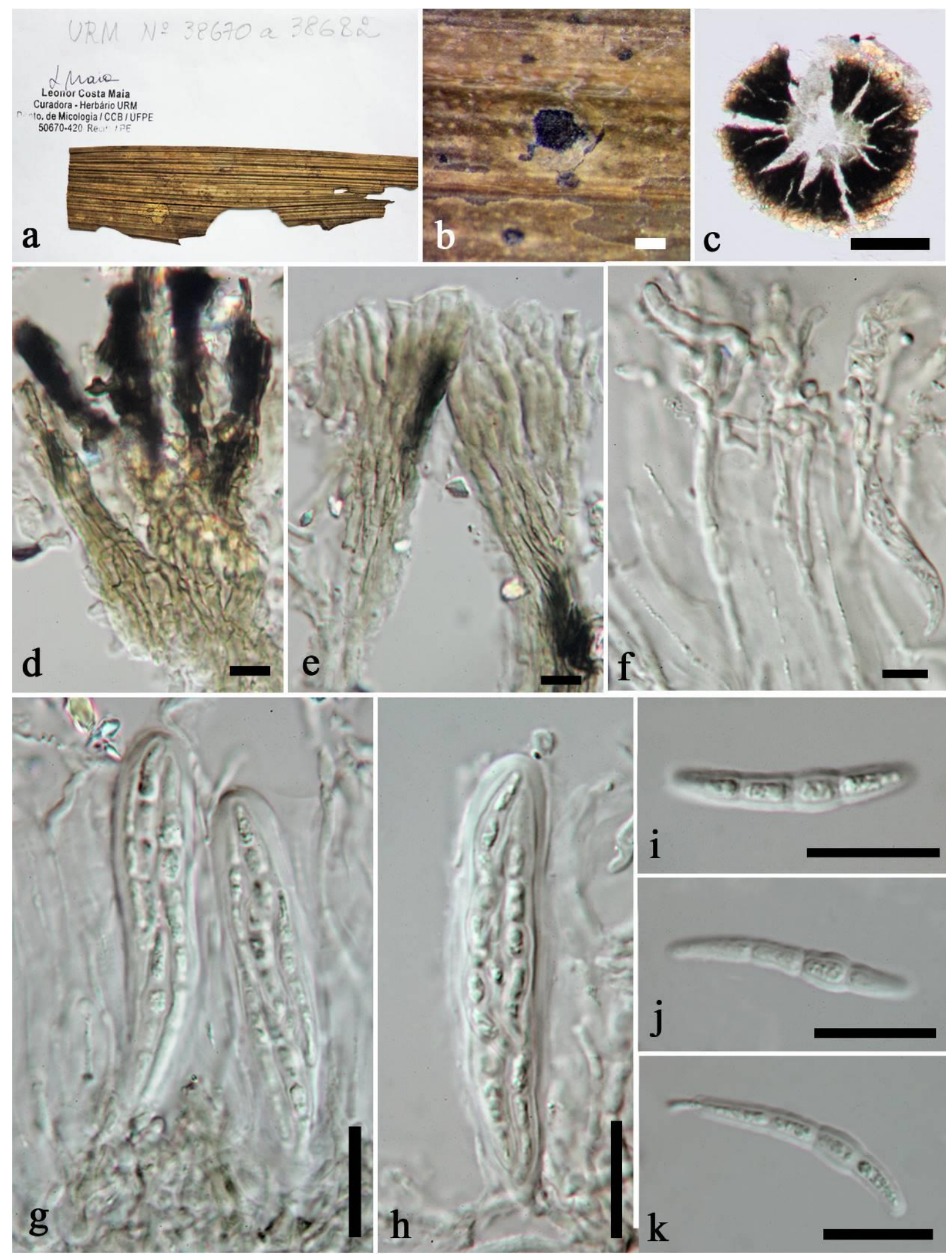

Figure 1 - Mazosia phyllosema (URM 38670). a Details of herbarium material and specimen. b Ascoma on host substrate. c-e Squash mounts of ascoma. f Pseudoparaphyses. g, h Asci. $\mathrm{i}-\mathrm{k}$ Ascospores. Scale bars: $\mathrm{b}=200 \mu \mathrm{m}, \mathrm{c}=100 \mu \mathrm{m}, \mathrm{d}-\mathrm{f}=5 \mu \mathrm{m}, \mathrm{g}-\mathrm{k}=20 \mu \mathrm{m}$.

Eurotiomycetes O.E. Erikss. \& Winka, Myconet 1(1): 6 (1997)

Chaetothyriales M.E. Barr, Mycotaxon 29: 502 (1987)

Microtheliopsidaceae O.E. Erikss.

Microtheliopsidaceae was introduced to accommodate the monotypic genus Microtheliopsis, which was typified by M. uleana (Müll. Arg.). Members of this family have been reported as 
foliicolous lichenized fungi (Lücking 2008, van den Broeck et al. 2014). They are widespread in tropical and cool temperate rainforests (Cannon \& Kirk 2007). Keys to Microtheliopsis species were provided by Van den Broeck et al. (2014). The genus presently has five species epithets, but one has been transferred to another genus (Index Fungorum 2018).

Microtheliopsis Müll. Arg., Flora, Regensburg 73: 195 (1890)

Epiphyllous, foliicolous on leaves and other understory plants or shrubs. Thallus formed on surface of leaves, composed of algal layer, thin, ecorticate, crustose, rounded to irregular at edge, smooth or thinly setose. Sexual morph: Ascomata perithecial, small, solitary, scattered, immersed in algal layer, easily visible from above, subglobose, rounded or slightly radiantly elongate, black to dark brown, edge dark brown, membranous, surrounded by septate, dark brown, irregular, branched hyphae, ostiolate. Peridium thin, composed of one layer of large brown cells of textura epidermoidea to angularis. Hamathecium gelatinous, lacking pseudoparaphyses. Asci 8-spored, bitunicate, clavate, base rounded, with an ocular chamber. Ascospores irregularly arranged in asci, fusiform, 1-3-septate or submuriform, smooth-walled, ends rounded. Asexual morph: Undetermined.

Type species - Microtheliopsis uleana Müll. Arg.

Notes - Microtheliopsis uleana is the type species of genus Microtheliopsis, which comprises four species (Lücking 2008, Van Den Broeck 2014). Microtheliopsis uleana differs from other species in Microtheliopsis by having ascospores with 3 septa. Microtheliopsis ramazaniana Van den Broeck, Lücking \& Ertz and M. uniseptata Herrera-Camp. \& Lücking have one-septate ascospores, and Microtheliopsis winkleri Lücking produces submuriform ascospores.

Microtheliopsis uleana Müll. Arg., Flora, Regensburg 73: 195 (1890)

Fig. 2

Index Fungorum number: IF395632; Facesoffungi number: FoF04616

Foliicolous on leaves. Thallus 4.5-7 mm long, 5-6 mm wide, formed on leaf surface, composed with one algal layer, thin, shell-like, shed easily, ecorticate, irregular at edge, green to yellowish brown, alga producing zoosporangia and gametangia, algal cells surrounded by hyphae of mycobiont, especially near ascomata. Sexual morph: Ascomata perithecial, 150-380 $\mu \mathrm{m}$ diam., small, solitary, scattered, immersed in algal layer, easily visible from above, subglobose, top rounded, black to dark brown, edge dark brown, membranous, surrounding by septate, dark brown, irregular, branched hyphae, ostiolate. Peridium 5-8 $\mu \mathrm{m}$ thick, composed of one layer of large brown cells of textura epidermoidea to angularis. Hamathecium gelatinous, lacking pseudoparaphyses. Asci $18-25 \times 7-16 \mu \mathrm{m}(\bar{x}=20.4 \times 8.6, \mathrm{n}=20), 8$-spored, bitunicate, clavate, base rounded, with an ocular chamber. Ascospores 10-13 $\times 4-5 \mu \mathrm{m}(\bar{x}=12.4 \times 4.6, \mathrm{n}=20)$, 3seriate, irregularly arranged in asci, fusiform, hyaline becoming pale greyish brown, 3-septate, smooth-walled, ends rounded. Asexual morph: Undetermined.

Material examined - COSTA RICA, Puntarenas Province, Reserva Biológica Carara, c. $15 \mathrm{~km}$ SSW of Orotina. Alt. m. 50 m. Co-ord.: $84^{\circ} 37^{\prime} \mathrm{W} ; 9^{\circ} 47^{\prime} \mathrm{N}$. Disturbed primary, c. $40 \mathrm{~m}$ tall forest, along trail near warden's house, foliicolous in undergrowth, 20 November 1988, H. Sipman \& P. Döbbeler (B 60 0178769).

Dothideomycetes O.E. Erikss. \& Winka, Myconet 1(1): 5 (1997)

In this part, nine orders, 21 families and 35 genera of Dothideomycetes, with three taxa of Dothideomycetes, genera incertae sedis were studied. The classification of Dothideomycetes follows Hyde et al. (2013) and Lui et al. (2017) and updated in Wijayawardene et al. (2018). Species descriptions with notes and illustrations are presented under the relevant genus.

Asterinales M.E. Barr ex D. Hawksw. \& O.E. Erikss., Syst. Ascom. 5(1): 177 (1986)

Asterinaceae Hansf., Mycol. Pap. 15: 188 (1946)

This family was studied by Hongsanan et al. (2014), however there is confusion surrounding what represents Asterinaceae sensu stricto and this has been discussed in Liu et al. (2017). 


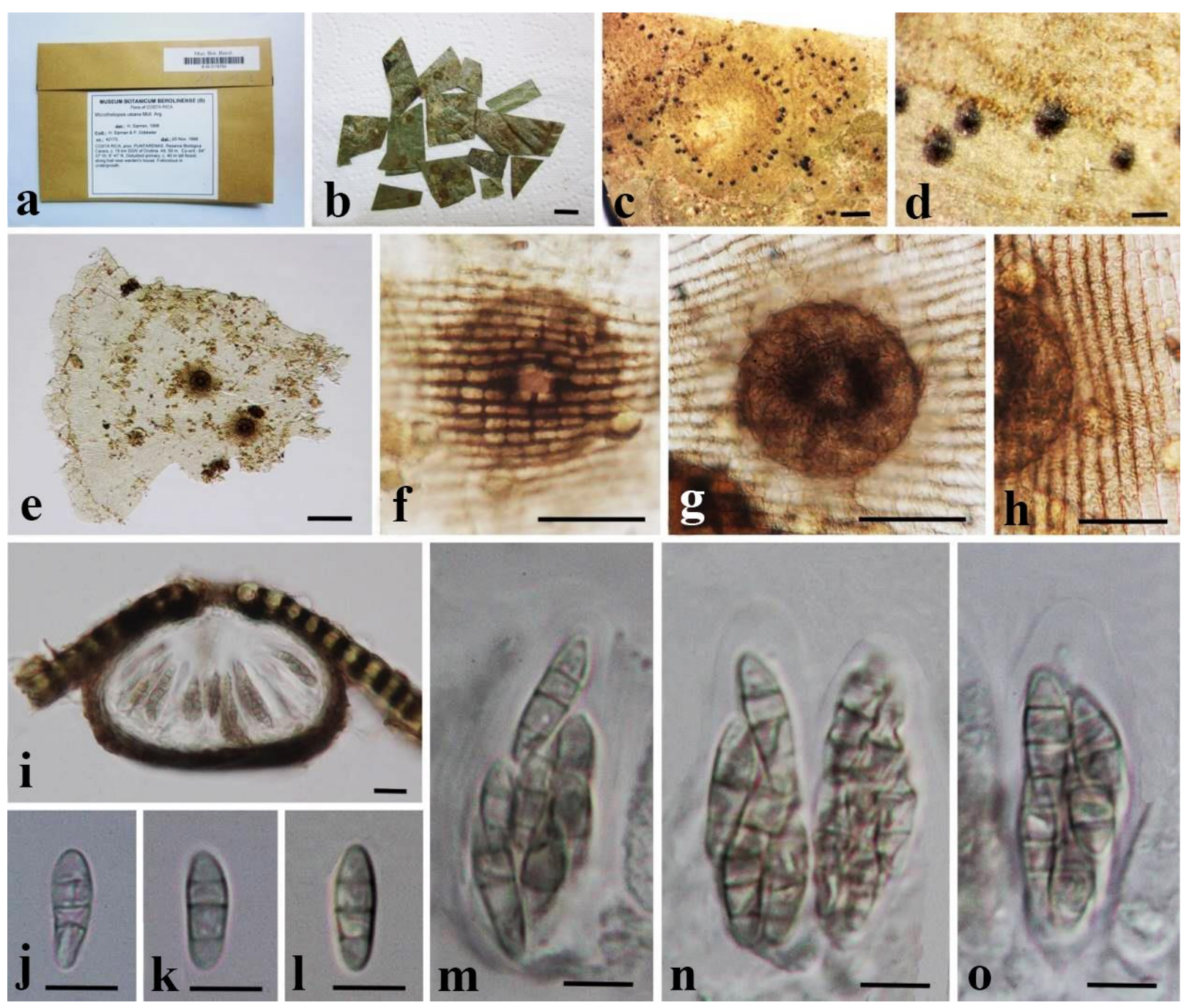

Figure 2 - Microtheliopsis uleana (B 60 0178769). a, b Herbarium label and specimen. c Thallus on leaf host. d Black to dark brown ascomata. e Shed thallus from host surface. f Brown ascoma immersed alga cells. g Globose ascoma. h Dark brown hyphae around ascoma. i Vertical section of ascoma. $\mathrm{j}-1$ Ascospores with 3-septa. $\mathrm{m}-\mathrm{o}$ Asci containing ascospores. Scale bars: $\mathrm{b}=20 \mathrm{~mm}$, $\mathrm{c}=1 \mathrm{~mm}, \mathrm{~d}, \mathrm{e}=200 \mu \mathrm{m}, \mathrm{f}-\mathrm{h}=50 \mu \mathrm{m}, \mathrm{i}=10 \mu \mathrm{m}, \mathrm{j}-\mathrm{o}=5 \mu \mathrm{m}$.

Pycnocarpon Theiss., Abh. K.K. Zool.-Bot. Ges. Wien 7(3): 31 (1913)

Epiphytes on surface of leaves, black, forming circular or irregular colonies on host surface. Superficial hyphae brown to black, branched, with appressoria, septate, scattered with thyriothecia. Sexual morph: Thyriothecia superficial, flattened, solitary, gregarious, black, circular or irregular, easily removed from the host surface. Asci 2-8-spored, bitunicate, fissitunicate, globose to subglobose, lacking a pedicel. Ascospores overlapping, brown, hyaline with sheath when immature, becoming brown when mature, upper cell wider than lower cell, 1-septate, strongly constricted at the septum. Asexual morph: Undetermined.

Type species - Pycnocarpon magnificum (Syd., P. Syd. \& E.J. Butler) Theiss.

Notes - Sydow et al. (1911) placed Asterina which included A. magnificum in Microthyriaceae. Subsequently, Theissen (1913a) introduced Pycnocarpon synonymizing A. magnificum under Pycnocarpon magnificum and placed the genus in Trichopeltinaceae. Lumbsch \& Huhndorf (2010) and Wijayawardene et al. (2018) accepted Pycnocarpon in Dothideomycetes genera incertae sedis. Pycnocarpon magnificum is characterized by superficial, web-like hypha, flattened thyriothecia opening by radiating star-like or longitudinal splits, saccate asci and conglobose ascospores, hyaline when young and becoming brown at maturity, 1-septate, strongly constricted at the septum, which is typical of members of Asterinaceae (Hongsanan et al. 2014). 
Thus, we place Pycnocarpon in the family Asterinaceae based on its morphology. In most aspects the taxon is typical of the genus Asterina according to the morphology described in Hyde et al. (2013) and Hongsanan et al. (2014), and Pycnocarpon magnificum is probably a species of this genus. However, we maintain it as a distinct genus for the time being, awaiting for molecular data that are needed to resolve the phylogenetic placement of Pycnocarpon and to determine if it is distinct from Asterina.

Pycnocarpon magnificum (Syd., P. Syd. \& E.J. Butler) Theiss., Abh. K.K. Zool.-Bot. Ges. Wien 7(3): 31 (1913)

Fig. 3

Index Fungorum number: IF180663; Facesoffungi number: FoF04617

Epiphytic on the surface of leaves, black, forming circular or irregular thallus on host surface. Superficial hyphae brown to black, branched, with appressoria, septate, with scattered thyriothecia and hyphopodia. Sexual morph: Thyriothecia 500-800 $\mu \mathrm{m}$ diam., superficial, flattened, solitary, gregarious, black, circular or irregular, easily removed from the host surface. Asci 55-95 × 50-75 $\mu \mathrm{m}(\bar{x}=70 \times 60 \mu \mathrm{m}, \mathrm{n}=20), 2-8$-spored, bitunicate, fissitunicate, globose to subglobose, lacking a pedicel. Ascospores $30-40 \times 20-25 \mu \mathrm{m}(\bar{x}=35 \times 22 \mu \mathrm{m}, \mathrm{n}=20)$, overlapping, brown, hyaline with sheath when immature, becoming brown when mature, upper cell wider than lower cell, oval to obovoid, 1-septate, strongly constricted at the septum. Asexual morph: Undetermined.

Material examined - MYANMAR, Moulmein, under surface of leaves of Terminalia sp., 7 January 1908, E.J. Butler (S-F46351, holotype).

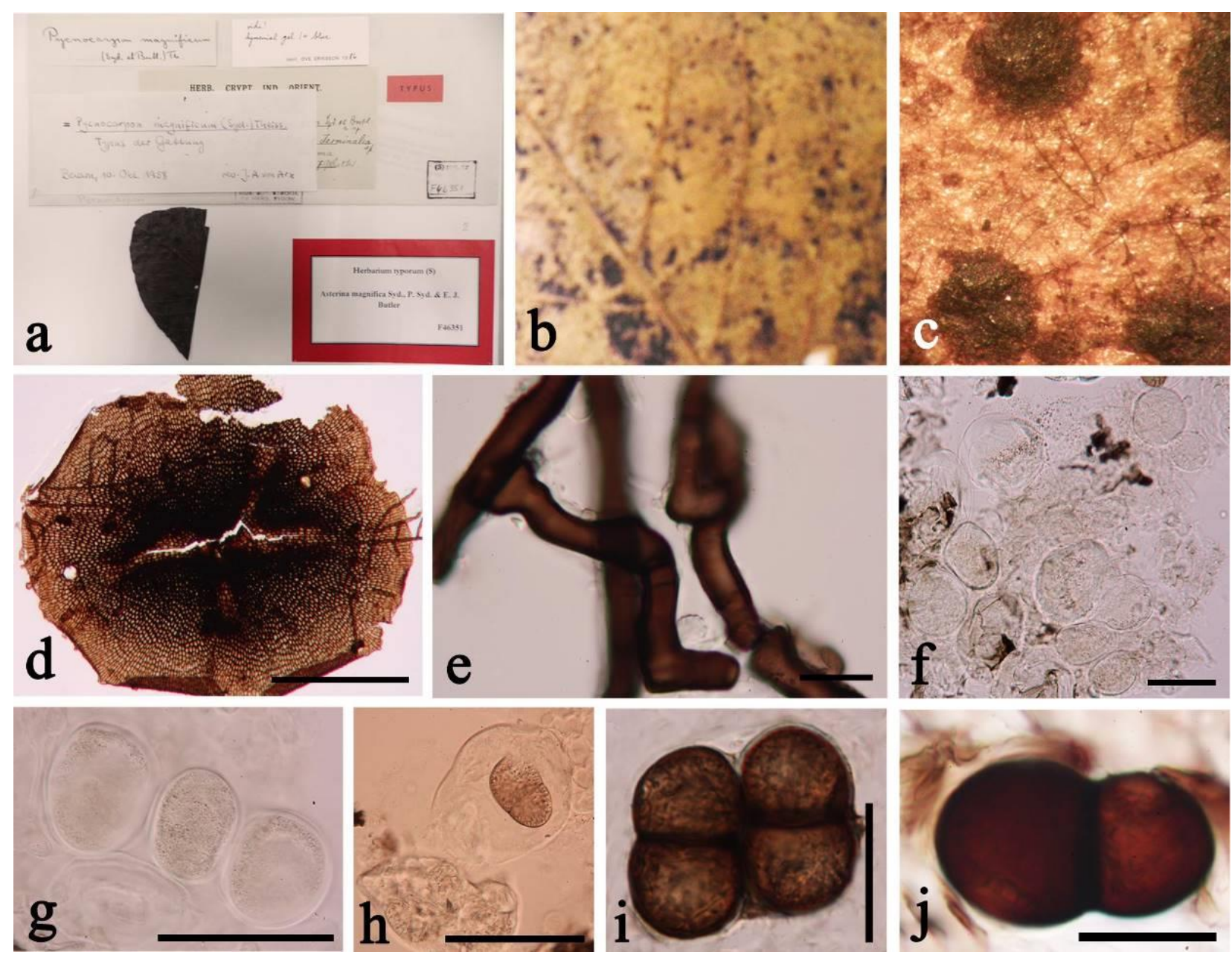

Figure 3 - Pycnocarpon magnificum (S-F46351, holotype), a Herbarium label and specimen. $\mathrm{b}$, c Thyriothecia on host. d Squash mount of thyriothecium. e Hyphopodia. $\mathrm{f}, \mathrm{g}$ Immature asci. $\mathrm{h}$ Mature broken ascus. i, j Ascospores. Scale bars: $\mathrm{d}=200 \mu \mathrm{m}, \mathrm{e},=20 \mu \mathrm{m}, \mathrm{f}, \mathrm{h}=50 \mu \mathrm{m}, \mathrm{g}=100$ $\mu \mathrm{m}, \mathrm{i}=30, \mathrm{j}=20 \mu \mathrm{m}$. 
Capnodiales Woron., Annls mycol. 23(1/2): 177 (1925)

Cladosporiaceae Nann., Repert. mic. uomo: 404 (1934)

The genus Cladosporium is the generic type of family Cladosporiaceae Nannizi. The Davidiella was introduced as sexual morph of Cladosporium s. str. (Braun et al. 2003), but later this genus was introduced in the family Davidiellaceae (Schoch et al. 2006). According to International Code of Nomenclature for algae, fungi and plants, Davidiella is synonymized under Cladosporium as the name Cladosporium has priority over Davidiella at generic rank and is also more commonly used in literature (Bensch et al. 2012). Eight genera were listed in Cladosporiaceae (Wijayawardene et al. 2018).

Cladosporium Link, Mag. Gesell. naturf. Freunde, Berlin 7: 37 (1816) [1815]

Endophytic, hyperparasitic, pathogenic and saprobic on animals, plants, humans and fungi. Asexual morph: (see Bensch et al. 2012). Sexual morph: Davidiella; Ascomata pseudothecial, gregarious or scattered on host, black, subglobose to globose, uni-loculate, immersed beneath stromata, superficial with a cellular black stroma. Peridium thick-walled, dark brown cells of textura globosa or angularis. Pseudoparaphyses frequently present in mature ascomata, hyaline, septate, subcylindrical. Asci 8-spored, bitunicate, clavate, pedicellate. Ascospores 4-5-seriate, hyaline, ellipsoid or ovoid, 1-septate, constricted at the septum, with broadly to narrowly rounded ends.

Type species - Cladosporium herbarum (Pers.) Link

Notes - The genus Cladosporium is one of the largest dematiaceous hyphomycetes (Bensch et al. 2012). Members of this genus characterized by a unique coronate structure of the conidiogenous loci and conidial hila, consisting of a central convex dome surrounded by a raised periclinal rim (David 1997). A monographic revision of the hyphomycete genus Cladosporium was provided in Bensch et al. (2012). Three major species complexes (C. cladosporioides, $C$. herbarum and $C$. sphaerospermum) were resolved based on morphology and DNA phylogeny (Bensch et al. 2015).

Davidiella was introduced by Braun et al. (2003) based on sexual morph connection by using phylogenetic study and these authors mention that all morphological characters of Davidiella are identical to Mycosphaerella, but are distinct in having Cladosporium asexual morphs. Aptroot (2006) transferred several additional species to Davidiella based on irregular cellular inclusions in their ascospores. Schoch et al. (2006) placed Davidiella in the family Davidiellaceae in the Capnodiales. Bensch et al. (2012) synonymized Davidiella under Cladosporium.

Cladosporium herbarum (Pers.) Link, Mag. Gesell. naturf. Freunde, Berlin 8: 37 (1816) [1815]

三Dematium herbarum Pers., Ann. Bot. (Usteri) 11: 32 (1794)

Figs 4, 5

Index Fungorum number: IF231458; Facesoffungi number: FoF04618

Pathogenic and saprobic on dry stalks of leaves. Sexual morph: Davidiella tassiana: Ascomata 113-140 $\mu \mathrm{m}$ diam., 85-115 $\mu \mathrm{m}$ high $(\bar{x}=129.5 \times 106 \mu \mathrm{m}, \mathrm{n}=5)$, pseudothecial, gregarious or scattered on host, black, subglobose to globose, uni-loculate, immersed beneath stromata, superficial with a cellular black stroma. Peridium $21-32 \mu \mathrm{m}$ wide $(\bar{x}=27 \mu \mathrm{m}, \mathrm{n}=10)$, consisting of 3-4 layers of dark brown cells of textura globosa or angularis. Pseudoparaphyses frequently present in mature ascomata, hyaline, septate, subcylindrical. Asci $64-80 \times 20-22 \mu \mathrm{m}(\bar{x}$ $=69 \times 21 \mu \mathrm{m}, \mathrm{n}=10), 8$-spored, bitunicate, clavate, short-pedicellate. Ascospores $28-38 \times 7.2-8.8$ $\mu \mathrm{m}(\bar{x}=34 \times 7.7 \mu \mathrm{m}, \mathrm{n}=20), 4-5$-seriate, hyaline, fusiform to oblong, 1-septate, constricted at the septum, with broadly to narrowly rounded ends. Asexual morph: mycelium superficial, unbranched, 1-5 $\mu \mathrm{m}$ wide, septate, sometimes constricted at septa, pale brown to brown, thick-walled. Conidiophores erect, straight to flexuous, unbranched, brown to dark brown, paler towards the apex, thick-walled. Conidiogenous cells conical to almost filiform or narrowly cylindrical with a single apical scar or conidiogenous loci. This type of scar has been called 'coronate' or described as 
'Cladosporium-type' (David, 1997). Conidia pale brown to brown when mature, 2-3 cells, ovoid to ellipsoid, guttulate to somewhat granular, usually only slightly attenuated towards base.

Material examined - ITALY, Trentino-Alto Adige, Bolazano, on dry stalks, June 1884, Rehm (S-F218065); USA, Colorado, Grand Mesa Mtn, on Carex geyeri Boott (Cyperaceae), 1 July 1930, R.W. Davidson (BPI 609770); USA, MACBRIDE Springs, Mt. Shasta, Siskiyou Co. alt. 5000 ft., Public Camp, on Carex fracta Boott (Cyperaceae), 7 April 1947, Cooke W.B.; Cooke Vivian G. (19289) (BPI 426946).

Johansoniaceae Doilom, Phookamsak \& K.D. Hyde, fam. nov.

Index Fungorum number: IF554793; Facesoffungi number: FoF04619

Epiphytic, saprobic, and associated with brown spots on leaves. Sexual morph: Mycelium superficial, septate, brown. Ascomata superficial, scattered, solitary, flattened, brown to black, pulvinate, uni-loculate, membranous, lacking ostioles, with or without hyphae at the base, sometimes with dots in hyphae at the central apex, with or without setae. Setae pale brown to brown, septate, surrounding ascomata, erect, straight to curved. Peridium with meandering arrangement, thin-walled at the base, with cells arranged in a textura angularis to textura globulosa. Hamathecium comprising septate, hypha-like, branched, anastomosing, pseudoparaphyses, intermingled among asci. Asci 8-spored, bitunicate, ellipsoid to subcylindrical or clavate, sessile to subsessile or with short furcate pedicel, thick-walled, with ocular chamber. Ascospores 2-3-seriate, hyaline, ovoid to ellipsoidal, 1-septate, apical cell wider than basal cell, with mucilaginous sheath. Asexual morph: Undetermined.

Family type - Johansonia Sacc.

Notes - The family Johansoniaceae is introduced to accommodate Johansonia and Orthobellus with Johansonia as the generic type of this family. Orthobellus was formerly placed in Schizothyriaceae (Silva et al. 1973, Wijayawardene et al. 2014), and was transferred to Dothideomycetes genera incertae sedis by Phookamsak et al. (2016). However, Orthobellus has morphological similarity to Johansonia in ascomata that are membranous, lacking ostioles, narrowly anastomosing pseudoparaphyses, thin-walled at the base and ascospores that are hyaline, ovoid to ellipsoidal, 1-septate, with an apical cell wider than basal cell. Thus, we place these two genera in Johansoniaceae.

Based on DNA sequence data of the nuclear ribosomal DNA (LSU) of $J$. chapadiensis, Crous et al. (2010) showed that Johansonia was a member of Dothideomycetes, Capnodiales, families incertae sedis, and closely related to Schizothyriaceae and Mycosphaerellaceae. More representative species and the type species, Johansonia setosa, need to be recollected for molecular study to resolve a natural classification. We tentatively place Johansonia to the new family Johansoniaceae based on morphology together with molecular data by Crous et al. (2010).

Genera in Johansoniaceae are similar to some members in Schizothyriaceae in having discoid, membranous ascomata, lacking ostioles, hyaline, didymosporous ascospores, but they differ by having uni-loculate ascomata, narrowly anastomosing pseudoparaphyses and a developed peridium at the base, mostly ellipsoid to subcylindrical or clavate asci. Schizothyriaceae members have mostly multi-loculate ascostromata, with each ascus forming in a locule in a network-like structure and have a poorly-developed peridium at the base and mostly subglobose to ovoid asci.

Johansonia Sacc., Syll. fung. (Abellini) 8: 785 (1889)

Saprobic on leaves, and associated with brown spots on leaves. Sexual morph: Ascomata superficial, on lower leaf surface, situated on a hyphal stroma, loose on the surface, scattered, solitary, pulvinate, dark brown to black, with brown setae. Setae pale brown to brown, separate, surrounding ascomata, erect, straight to curved, thick-walled and smooth-walled, with basal T-cell devoid of rhizoids, slightly constricted at the septa, tapering towards the apex, acutely to obtusely rounded, apical septum. Peridium comprising brown cells arranged in a textura angularis to textura globulosa. Hamathecium comprising, septate, hypha-like, branched, pseudoparaphyses, intermingled among asci. Asci 8-spored, bitunicate, subcylindrical to clavate, with short furcate 
pedicel, thick-walled, with an ocular chamber. Ascospores 2-3-seriate, hyaline, ovoid to ellipsoidal, septate, slightly constricted at the septum, slightly curved, thick-walled, apical cell wider than basal cell, slightly rounded at both ends. Asexual morph: Undetermined.
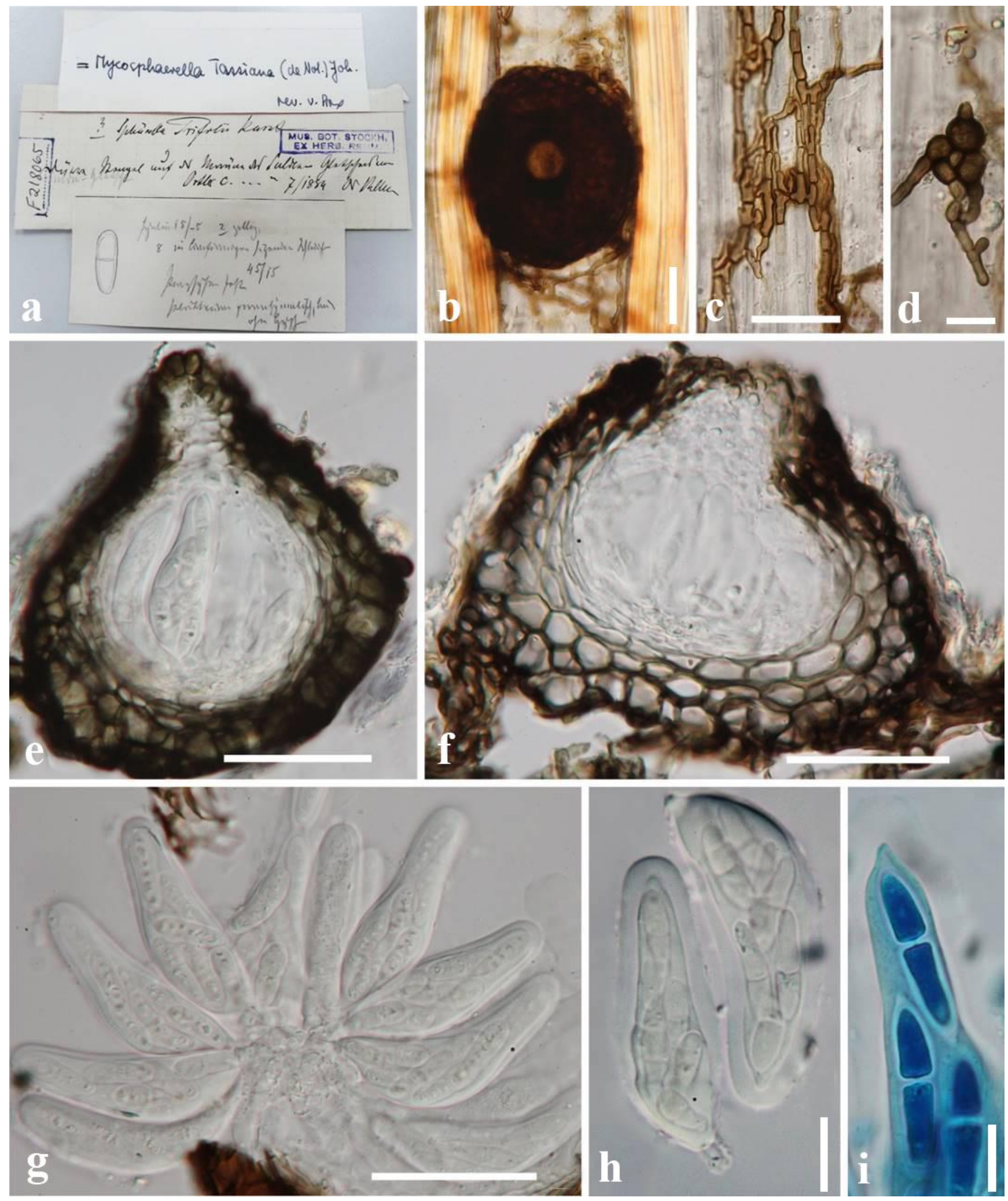

Figure 4 - Cladosporium herbarum (S-F218065, sexual morph of Davidiella tassiana). a Herbarium label. b Ascoma with ostiole. c, d Hyphae. e, f Vertical sections through the ascomata and peridium. g, $\mathrm{h}$ Asci. i Ascospores stained in lactophenol cotton blue. Scale bars: $\mathrm{b}=100 \mu \mathrm{m}$, $\mathrm{c}-\mathrm{f}=50 \mu \mathrm{m}, \mathrm{g}=20 \mu \mathrm{m}, \mathrm{h}-\mathrm{i}=10 \mu \mathrm{m}$. 

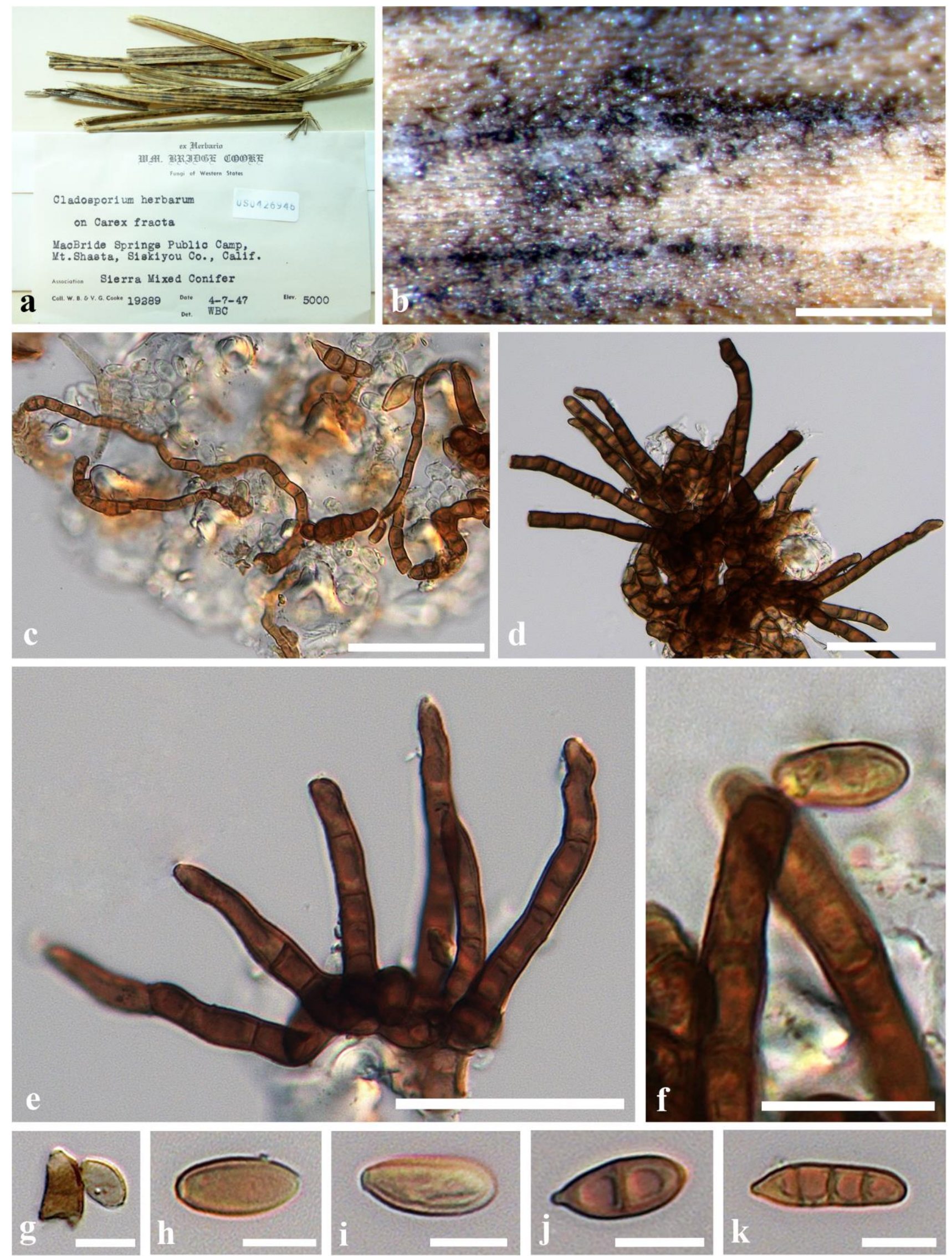

Figure 5 - Cladosporium herbarum (BPI 426946). a Herbarium label and specimen. b Appearance of black mycelium on host surface. c Hyphae. d, e Conidiophores. $\mathrm{f}$, g Conidiophores with conidia and conidiogenous cell. $\mathrm{h}, \mathrm{i}$ Immature conidia. j, $\mathrm{k}$ Mature conidia. Scale bars: $\mathrm{b}=200 \mu \mathrm{m}, \mathrm{c}, \mathrm{e}, \mathrm{f}=$ $50 \mu \mathrm{m}, \mathrm{d}, \mathrm{g}=20 \mu \mathrm{m}, \mathrm{h}-\mathrm{k}=10 \mu \mathrm{m}$. 
Type species - Johansonia setosa (G. Winter) Sacc.

Notes - Johansonia comprises 13 species (Index Fungorum 2018), with J. setosa as the type species (Wijayawardene et al. 2017a). Johansonia was formerly assigned to Schizothyriaceae by Müller \& von Arx (1962). In a later study, this genus was placed in Saccardiaceae (von Arx \& Müller 1975) and placed in Phillipsiellaceae in Loculoascomycetes (Barr 1993). Lumbsch \& Huhndorf (2007) and Wijayawardene et al. (2018) listed it in Saccardiaceae, Ascomycota, family incertae sedis. There are no DNA sequence data for the type species in GenBank (2018), although Crous et al. (2010) provided such data for J. chapadiensis. We examined the isotype of Johansonia setosa and place it in Johansoniaceae based on morphology and phylogenetic analysis of Crous et al. (2010).

Johansonia setosa (G. Winter) Sacc., Syll. fung. (Abellini) 8: 785 (1889)

Fig. 6

$\equiv$ Ravenelula setosa G. Winter, Revue mycol., Toulouse 7(no. 27): 208 (1885)

Index Fungorum number: IF150887; Facesoffungi number: FoF04620

Saprobic on leaves of Sapindaceae Juss. Sexual morph: Ascomata 50-85 $\mu \mathrm{m}$ high, up to 360 $\mu \mathrm{m}$ diam., superficial, on lower leaf surface, situated on a hyphal stroma, loosely on surface, scattered, solitary, pulvinate, dark brown to black, with brown setae. Setae pale brown to brown, separate, surrounding ascomata, erect, straight to curved, thick-walled, smooth, with basal T-cell devoid of rhizoids, slightly constricted at the septa, tapering towards the apex, acutely to obtusely rounded, 7-12-septate, 110-227 × 5-8 $\mu \mathrm{m} ; 3-6 \mu \mathrm{m}$ wide at apical septum. Peridium 13-22 $\mu \mathrm{m}$ diam., consisting of 3-6 layers of brown cells of textura angularis to textura globulosa. Hamathecium comprising 1.9-3 $\mu \mathrm{m}$ wide, septate, hypha-like, branched pseudoparaphyses, intermingled among asci. Asci 32-48 $\times 10-15 \mu \mathrm{m}(\bar{x}=39 \times 13 \mu \mathrm{m}, \mathrm{n}=30), 8$-spored, bitunicate, subcylindrical to clavate, with short furcate pedicel, with an ocular chamber. Ascospores 10-16 $\times$ 5-7 $\mu \mathrm{m}(\bar{x}=12 \times 6 \mu \mathrm{m}, \mathrm{n}=30), 2-3$-seriate, hyaline, ovoid to ellipsoidal, medially 1-septate, slightly constricted at the septum, slightly curved, thick-walled, apical cell wider than basal cell, slightly rounded at both ends, with mucilaginous sheath. Asexual morph: Undetermined.

Material examined - PARAGUAY, Guarapi, on leaves of Sapindaceae, A. Balansa (S-F5991, isotype).

Phaeothecoidiellaceae K.D. Hyde \& Hongsanan, Mycosphere 8(1): 140 (2017)

This family was introduced by Hongsanan et al. (2017b) to accommodate Chaetothyrina, Houjia and Phaeothecoidiella and is placed in the order Capnodiales. Zeng et al. (2018) added a fourth genus, Translucidithyrium. Chaetothyrina was introduced by Theissen (1913b) and is characterized by ascomata with setae, hyaline, 1-septate ascospores, and the absence of superficial hyphae (Reynolds \& Gilbert 2005). Houjia is hyphomycetous and characterized by brown, septate, branched hyphae, solitary, monoblastic conidiogenous cells, and euseptate conidia (Yang et al. 2010). Phaeothecoidiella is hyphomycetous and characterized by brown, regularly septate, branched hyphae with internal pigmented, phragmospore-like endoconidia (Yang et al. 2010, Zeng et al. 2018). Because of the similarities of Rivilata with Translucidithyrium, we place them in the family Phaeothecoidiellaceae pending molecular confirmation.

\section{Rivilata Kohlm., Volkm.-Kohlm. \& O.E. Erikss., Can. J. Bot. 76(3): 470 (1998)}

Saprobic on leaves. Sexual morph: Thyriothecia pulvinate, flattened or slightly convex on top, dark brown when wet, appearing black when dry, anchored with short hyaline hyphae in the epidermal cells of the host, hymenium covered by an epithecium, developing under the cuticle, which eventually peels off, becoming superficial, single or in small groups. Epithecium composed of short dark brown hyphoid cells; opening by irregular slits when moistened and exposing the hymenium. Hamathecium comprising pseudoparenchymatous tissue of hyaline stromatal cells surrounding the asci. Asci 8-spored, bitunicate, clavate, upper part ellipsoidal to obovate, short pedicellate, thick at the apex, dehiscence rostrate, without an apical apparatus, with oculus. Ascospores irregularly arranged in the ascus, ellipsoidal, uniseptate, slightly constricted at the 
septum, upper cell wider than the lower one, smooth-walled, hyaline, full of oil droplets. Asexual morph: Undetermined

Type species - Rivilata ius Kohlm., Volkm.-Kohlm. \& O.E. Erikss.

Notes - Kohlmeyer et al. (1998) introduced the genus Rivilata with $R$. ius as a type species. Rivilata was thought to be similar to Schizothyrium, but all species in Schizothyrium have epicuticular ascomata, whereas Rivilata has subcuticular ascomata (Kohlmeyer et al. 1998). The genus Rivilata resembles members of the Saccardiaceae (syn. Phillipsiellaceae). Lumbsch \& Huhndorf (2010) and Wijayawardene et al. (2018) placed Rivilata in Saccardiaceae. In this study we re-examined the holotype of Rivilata ius and place it in Phaeothecoidiellaceae based on its morphological similarity to Translucidithyrium.
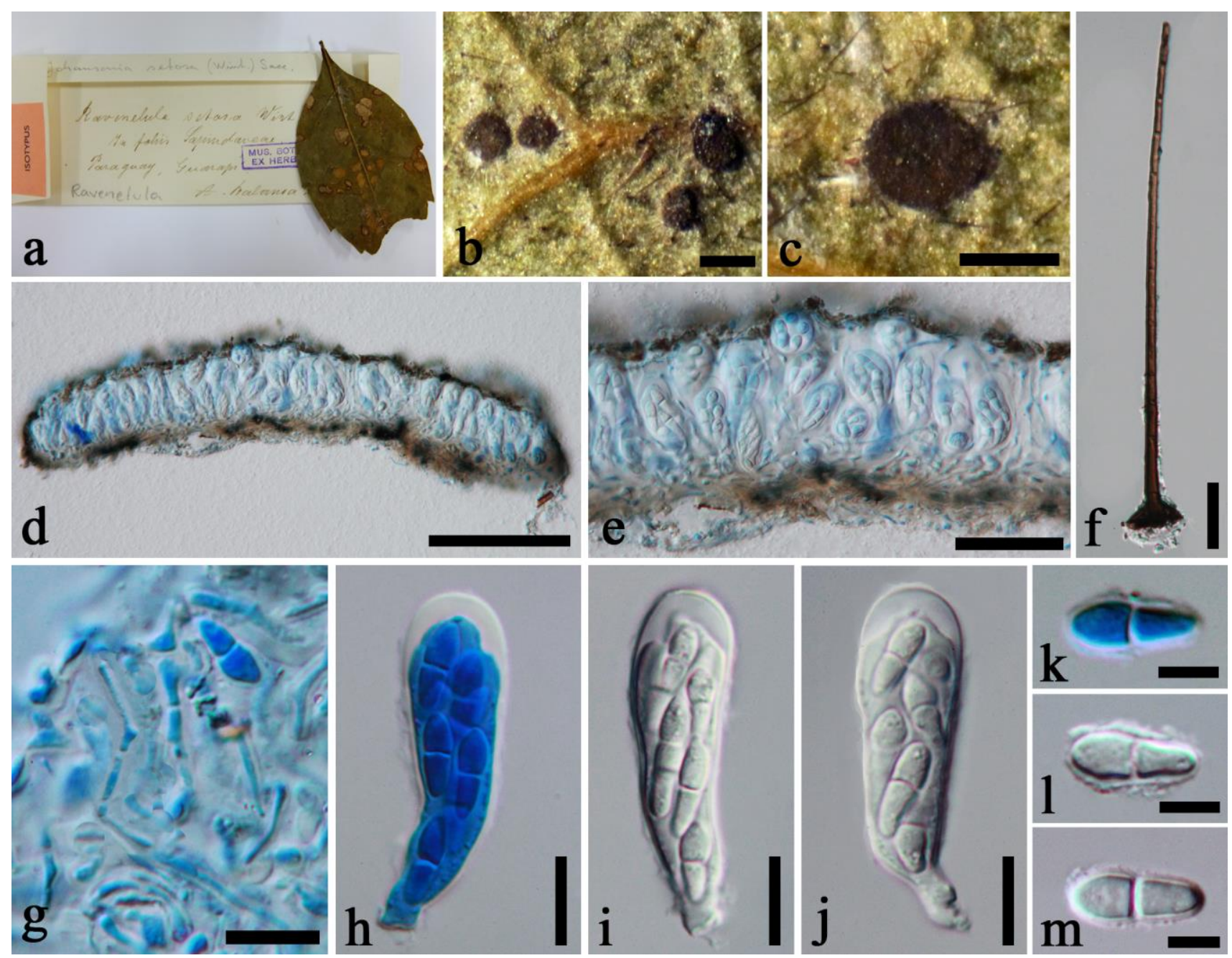

Figure 6 - Johansonia setosa (S-F5991, isotype). a Herbarium label and specimen. b Ascomata on leaf surface from above. c Close up of ascoma on leaf surface from above. d-e Vertical section through an ascoma. f Setae. g Pseudoparaphyses. $\mathrm{h}-\mathrm{j}$ Asci. $\mathrm{k}-\mathrm{m}$ Ascospores. Note: $\mathrm{d}, \mathrm{e}, \mathrm{g}, \mathrm{h}, \mathrm{k}$ stained in lactophenol cotton blue. Scale bars: $b, c=300 \mu \mathrm{m}, \mathrm{d}=100 \mu \mathrm{m}, \mathrm{e}=30 \mu \mathrm{m}, \mathrm{f}=20 \mu \mathrm{m}$, $\mathrm{g}-\mathrm{j}=10 \mu \mathrm{m}, \mathrm{k}-\mathrm{m}=5 \mu \mathrm{m}$.

Rivilata ius Kohlm., Volkm.-Kohlm. \& O.E. Erikss., Can. J. Bot. 76(3): 472 (1998)

Fig. 7

Index Fungorum number: IF447035; Facesoffungi number: FoF04621

Saprobic on leaves of Juncus roemerianus. Sexual morph: Thyriothecia 40-70 $\mu \mathrm{m}$ high $\times$ 95-145 $\mu \mathrm{m}$ diam. $(\bar{x}=56 \times 120 \mu \mathrm{m}, \mathrm{n}=10)$, superficial, solitary, scattered, flattened or slightly convex on top, dark brown when wet, appearing black when dry, basal peridium poorly developed. Epithecium composed of short dark brown hyphoid cells, brown to reddish brown. Hamathecium comprising 1-2 $\mu \mathrm{m}$ wide, intricata or pseudoparenchymatous tissue of hyaline stromatal cells 


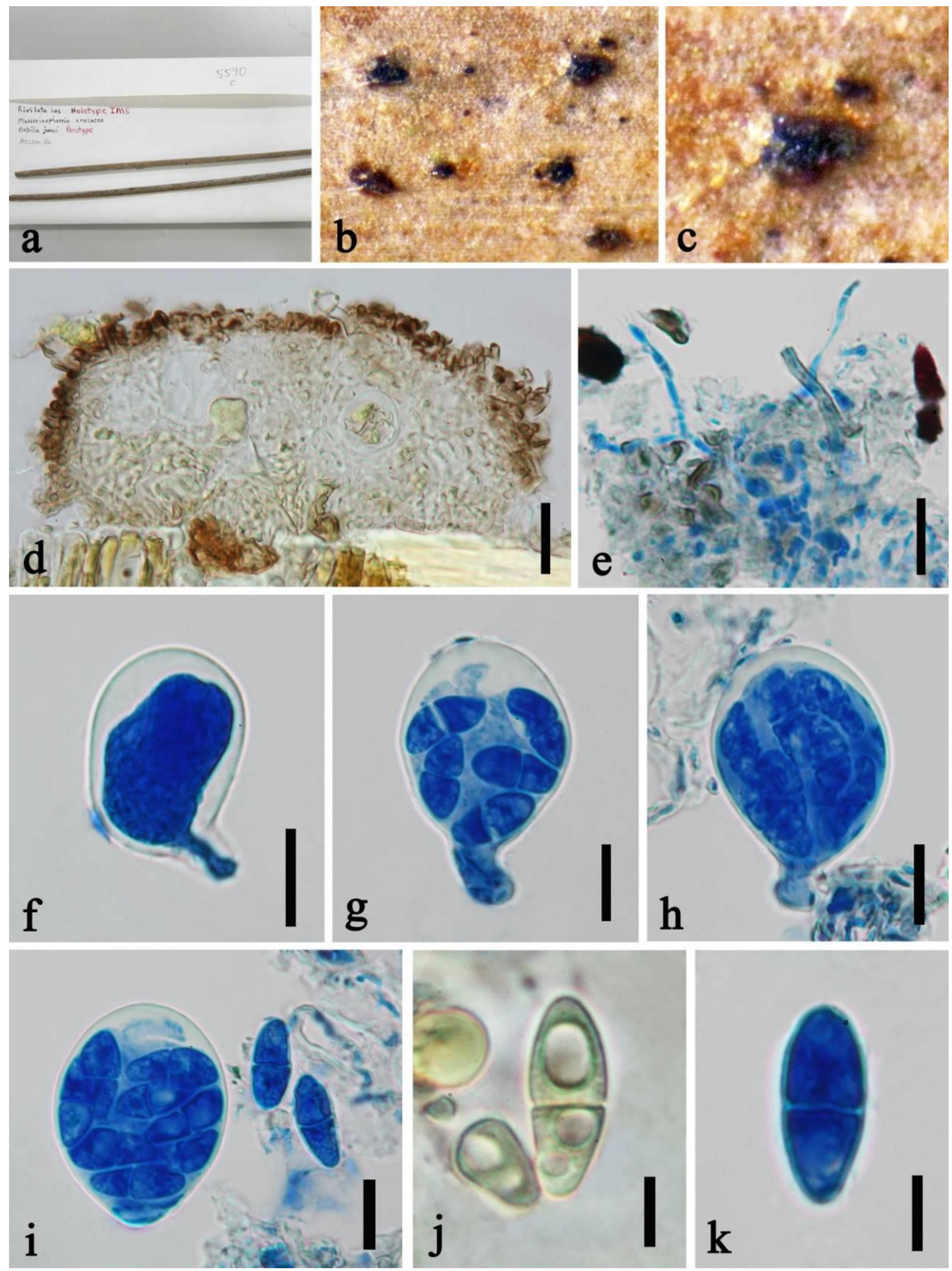

Figure 7 - Rivilata ius (J.K. 5590 (IMS), holotype). a Herbarium label and specimen. b Ascomata on substrate. c Close up of ascoma on substrate. d Vertical section through ascoma. e Pseudoparaphyses. f Immature asci. g, h Mature asci. i Asci and ascospores. j, k Ascospores. Note: $\mathrm{e}-\mathrm{i}, \mathrm{k}$ stained in lactophenol cotton blue. Scale bars: $\mathrm{d}=20 \mu \mathrm{m}, \mathrm{e}-\mathrm{i}=10 \mu \mathrm{m}, \mathrm{j}, \mathrm{k}=5 \mu \mathrm{m}$. 
surrounding the asci, septate. Asci 32-42 $\times 22-26 \mu \mathrm{m}(\bar{x}=37 \times 24 \mu \mathrm{m}, \mathrm{n}=20)$, 8-spored, bitunicate, globose to subglobose, short-pedicellate, apically rounded with indistinct ocular chamber. Ascospores 13-18 $\times 5-7.5 \mu \mathrm{m}(\bar{x}=16 \times 6.5 \mu \mathrm{m}, \mathrm{n}=20)$, crowded or irregularly arranged in the ascus, ellipsoid or obovoid, hyaline, smooth-walled, 1-septate, slightly constricted at the septum, upper cell wider than the lower cell, guttulate. Asexual morph: Undetermined.

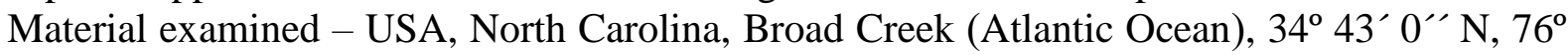
$55^{\prime} 7^{\prime \prime}$ W., on leaves of Juncus roemerianus Scheele (Juncaceae), 7 June 1996, J.J. Kohlmeyer, B. Volkman-Kohlmeyer (J.K. 5590 (IMS), holotype).

Schizothyriaceae Höhn. ex Trotter, Sacc., D. Sacc. \& Traverso [as 'Schizothyrieae'], in Saccardo, Syll. fung. (Abellini) 24(2): 1254 (1928)

Hyde et al. (2013) provided details of Schizothyriaceae. Phookamsak et al. (2016) resolved the genera in Schizothyriaceae by examining the type and other specimens from herbaria worldwide. Nine genera were listed under this family by Wijayawardene et al. (2018). In this study we determined that Vonarxella are probably similar to this family and thus we place it in Schizothyriaceae.

Vonarxella Bat., J.L. Bezerra \& Peres, Riv. Patol. veg., Pavia, sér. 4 1(1-2): 61 (1965).

Facesoffungi number: FoF04673

Epiphytic on the lower surface of leaves. Mycelium not observed. Sexual morph: Ascostromata superficial, solitary, black, flattened, circular, easily removed from the host surface, multi-loculate, hemispherical, lacking ostioles, upper wall composed of meandering cells, arranged and branching from the central to the outer rim. Peridium thin-walled, composed of dark brown to black pseudoparenchymatous cells, arranged in a textura angularis, comprising irregular meandering arrangement of dark brown, compact cells, poorly-developed at the base. Hamathecium comprising numerous, septate, hypha-like pseudoparaphyses, embedded in a gelatinous matrix. Asci 8-spored or more, bitunicate, fissitunicate, cylindro-clavate to clavate, with an ocular chamber, with or without pedicel, asci arising from the base of the ascomata. Ascospores overlapping 3-4seriate, hyaline, obovoid to ellipsoidal, 1-septate, apical cell wider and shorter than lower cell, lower cell narrow and tapering to rounded base. Asexual morph: Undetermined.

Type species - Vonarxella dipterygis Bat., J.L. Bezerra \& Peres

Notes -The genus Vonarxella (Saccardiaceae) has only one species, with $V$. dipterygis as the type species. This was found on leaves of Dipteryx alata in Brazil in 1965. Vonarxella is similar to Schizothyrium. It is possibly a member of Schizothyriaceae (Phookamsak et al. 2016) based on ascostromata that are flattened, multi-loculate, a peridium that comprises irregular meandering arrangement of dark brown, compact cells, poorly-developed at the base, and ascospores that are 1septate, slightly constricted at the septum, and wider in upper cell. Thus, we classify Vonarxella in the Schizothyriaceae.

Vonarxella dipterygis Bat., J.L. Bezerra \& Peres [as 'diptericis'], Riv. Patol. veg., Pavia, sér. 4 1(12): 62 (1965)

Index Fungorum number: IF340976; Facesoffungi number: FoF04622

Fig. 8

Epiphytic on the lower surface of leaves. Mycelium not observed. Sexual morph: Ascostromata superficial, solitary, black, flattened, circular, easily removed from the host surface, multi-loculate, hemispherical, lacking ostioles, upper wall composed of meandering cells, arranged and branching from the central to the outer rim. Peridium thin-walled, composed of dark brown to black pseudoparenchymatous cells, arranged in a textura angularis, comprising irregular meandering arrangement of dark brown, compact cells, poorly-developed at the base. Hamathecium comprising numerous, 1-2 $\mu \mathrm{m}$ wide, septate, hypha-like pseudoparaphyses, embedded in a gelatinous matrix. Asci 44-58 $\times 17-24 \mu \mathrm{m}(\bar{x}=50 \times 22 \mu \mathrm{m}, \mathrm{n}=15), 8$-spored or more, bitunicate, fissitunicate, cylindro-clavate to clavate, ocular chamber, with or without pedicel, thick-walled, asci arising from the base of the ascomata. Ascospores 11-15 $\times 3-5 \mu \mathrm{m}(\bar{x}=14 \times 4 \mu \mathrm{m}, \mathrm{n}=15)$, 
overlapping 3-4-seriate, hyaline, obovoid to ellipsoidal, 1-septate, slightly constricted at the septum, slightly curved, apical cell wider and shorter than lower cell, lower cell narrow and tapering to rounded base, smooth-walled, surrounded by a mucilaginous sheath. Asexual morph: Undetermined.

Material examined - BRAZIL, Paracatú, Minas Gerais, on leaves of Dipteryx alata Vogel (Leguminosae), 3 June 1960, E.P. Henringer (URM 19534, holotype).
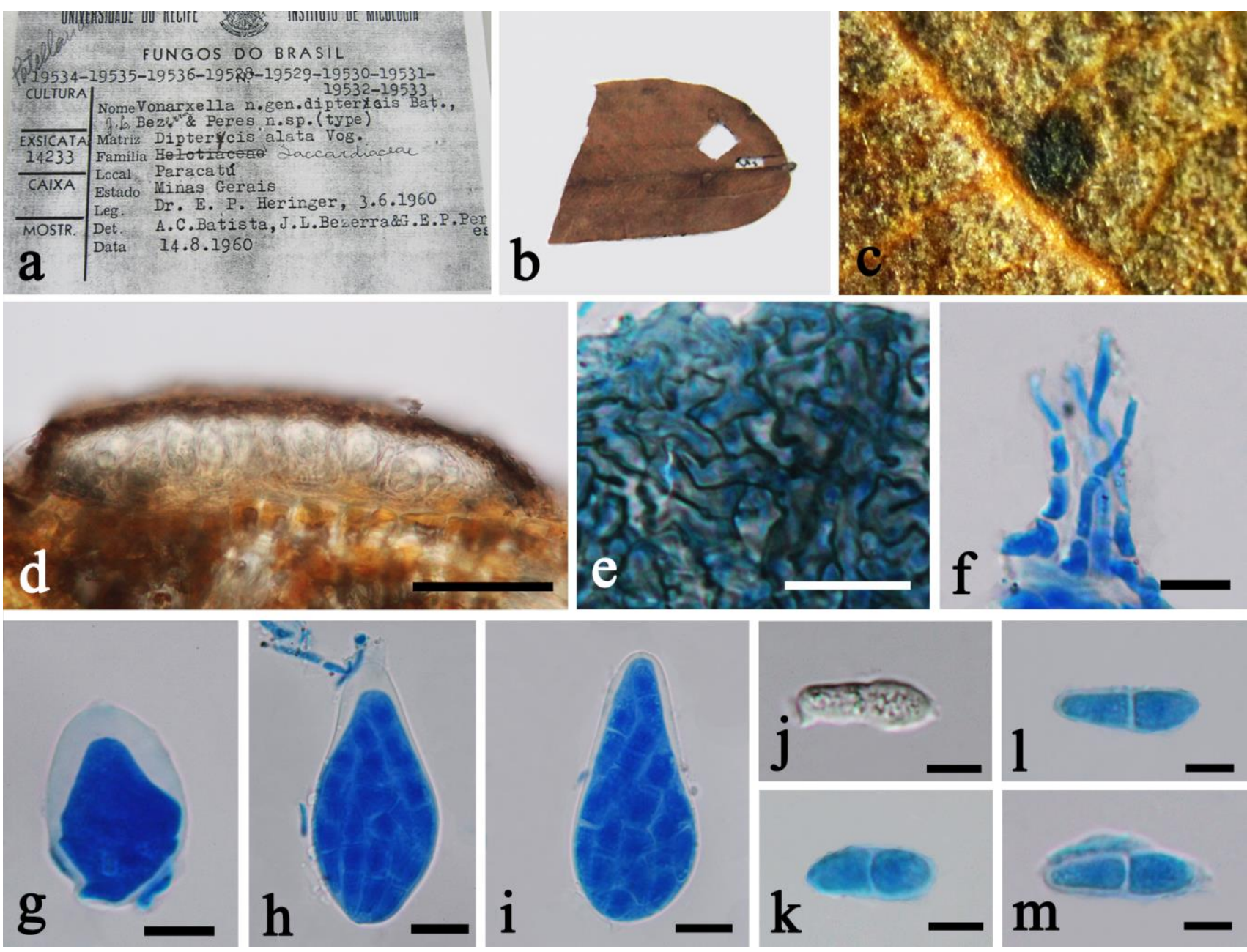

Figure 8 - Vonarxella dipterygis (URM 19534, holotype). a Herbarium label. b Specimen. c Ascostroma on host. d Section through ascostroma. e Peridium structure seen from above. f Pseudoparaphyses. $\mathrm{g}-\mathrm{i}$ Asci. $\mathrm{j}-\mathrm{m}$ Ascospores. Note: $\mathrm{e}-\mathrm{i}, \mathrm{k}-\mathrm{m}$ stained in lactophenol cotton blue. Scale bars: $\mathrm{d}=50 \mu \mathrm{m}, \mathrm{e}-\mathrm{i}=10 \mu \mathrm{m}, \mathrm{j}-\mathrm{m}=5 \mu \mathrm{m}$.

Gloniales Jayasiri \& K.D. Hyde, Mycosphere (In prep)

Gloniaceae E. Boehm, C.L. Schoch \& Spatafora, Mycol. Res. 113(4): 468 (2009)

Originally Gloniaceae was proposed as a sub-familial taxonomic rank under the family Hysteriaceae based on Hysterographium and Glonium Corda (1842). Boehm et al. (2009a) emended and restricted this sub-familial rank and elevated Gloniaceae to family rank based on a single genus (Glonium circumserpens EB 0331, EB 0332 and G. stellatum CBS 207.34). Gloniaceae was placed close to the Mytilinidiaceae in the multigene phylogenies of LSU, SSU, TEF1 and RPB2 (Boehm et al. 2009a). However, Boehm et al. (2009a) did not include Gloniaceae within the Mytilinidiales but considered Gloniaceae in Pleosporomycetidae incertae sedis, due to the highly divergent morphology associated with the genus Glonium. These include character states related to the hamathecium type or pseudothecial shape (persistent cellular pseudoparaphyses in the Gloniaceae versus narrow trabeculate pseudoparaphyses in the Mytilinidiaceae), and to the fruitbody (dichotomously branched in the Gloniaceae versus conchate in the Mytilinidiaceae) 
(Boehm et al. 2009b). Hysterographium was retained within the Hysteriaceae (Zogg 1962). Key to asexual states of Gloniaceae was provided in Hyde et al. (2013) with two genera, Cleistonium and Cenococcum. Later, Cleistonium was accepted as Ascomycota, genus incertae sedis (Wijayawardene et al. 2017a). Cenococcum has been recognized as a member of Gloniaceae based on five nuclear loci of SSU, LSU, TEF1, RPB1 and RPB2 (Spatafora et al. 2012). Three genera were recently listed in Gloniaceae (Wijayawardene et al. 2018). Jayasiri et al. (2018) placed Gloniaceae in the new order Gloniales.

\section{Glonium Muhl., Cat. Pl. Amer. Sept.: 101 (1813)}

Saxicolous, terricolous or lignicolous on bark, wood or soil. Sexual morph: Ascomata hysterothecia, carbonaceous to coriaceous, black, scattered, contiguous, semi-immersed to superficial, subiculum or without, with a longitudinal slit at the median, quadrilateral, not branching to dichotomously branching. Exciple composed of a textura angularis, comprising of two cell layers, outer layer comprising black to dark reddish, thick-walled cells, inner layer comprising hyaline, thin-walled cells. Hamathecium comprising hyaline, filiform, hypha-like, dense, septate pseudoparaphyses, embedded in a gelatinous matrix. Asci 8-spored, bitunicate, fissitunicate, subcylindrical to cylindro-clavate, apically rounded, with an ocular chamber, with a short furcate pedicel. Ascospores overlapping 1-2-seriate, hyaline, 1-septate, constricted at the transverse septa, upper cell wider than the lower cell, with a gelatinous sheath, smooth-walled. Asexual morph: asteromella-like

Type species - Glonium stellatum Muhl.

Notes - The genus Glonium was transferred from the Hysteriaceae to Gloniaceae, which is listed as family incertae sedis within the Pleosporomycetidae (Boehm et al. 2009b). Jayasiri et al. (2018) placed Glonium in the family Gloniaceae, order Gloniales. It is a genus of saprobic Dothideomycetes that produces darkly pigmented, carbonaceous, hysteriate apothecia, and has not been known as biotrophic (Spatafora et al. 2012). Glonium stellatum was established as type species by Mühlenberg (1813) (see description and illustration in Hyde et al. (2013)). The specimen of G. lineare labeled as Psiloglonium lineare (Fr.) Petr. is described below from S herbarium. It is not type material, but it is typical for the species. A brief description was provided in Fries (1823) as Hysterium lineare, and in Saccardo (1883) with descriptions as G. lineare.

Glonium lineare (Fr.) De Not., G. bot. ital. 2(1.1): 594 (1846)

$\equiv$ Hysterium lineare Fr., Syst. mycol. (Lundae) 2(2): 583 (1823)

Fig. 9

= Hysterium lineare Fr., Syst. mycol. (Lundae) 2(2): 583 (1823)

= Glonium lineare (Fr.) De Not., G. bot. ital. 2(1.1): 594 (1846) f. lineare

= Psiloglonium lineare (Fr.) Petr., Annls mycol. 21(3/4): 227 (1923)

= Hysterium lineare Fr., Syst. mycol. (Lundae) 2(2): 583 (1823) var. lineare

= Glonium lineare f. angustissimum De Not., G. bot. ital. 2(1.1): 594 (1846)

Index Fungorum number: IF140107; Facesoffungi number: FoF04623

Saprobic on dead wood. Sexual morph: Ascomata $240-320 \mu \mathrm{m}$ high $\times 255-535 \mu \mathrm{m}$ diam. $(\bar{x}$ $=265 \times 490 \mu \mathrm{m}, \mathrm{n}=15$ ), hysterothecia, carbonaceous to coriaceous, black, scattered, contiguous, semi-immersed to superficial, subiculum, with a longitudinal slit at the median, quadrilateral. Exciple 25-65 $\mu \mathrm{m}$ thick at the sides, composed of a textura angularis, comprising two cell layers, outer layer comprising black to dark reddish, thick-walled cells, inner layer comprising hyaline, thin-walled cells. Hamathecium comprising 0.9-1.5 $\mu \mathrm{m}$ wide, filiform, hypha-like, dense, septate pseudoparaphyses, embedded in a gelatinous matrix. Asci $65-98 \times 9.5-14 \mu \mathrm{m}(\bar{x}=81 \times 11 \mu \mathrm{m}, \mathrm{n}$ $=15), 8$-spored, bitunicate, fissitunicate, subcylindrical to cylindro-clavate, apically rounded, with an ocular chamber, with a short furcate pedicel. Ascospores $11-15.5 \times 5-7.5 \mu \mathrm{m}(\bar{x}=13 \times 6 \mu \mathrm{m}, \mathrm{n}$ = 30), overlapping 1-2-seriate, hyaline, 1-septate, constricted at the transverse septum, upper cell wider than the lower cell, with a gelatinous sheath, overlapping 1-2-seriate, smooth-walled. Asexual morph: Undetermined.

Material examined - Acer platanoides L. (Aceraceae), M.A. Lindblad (S-F221568). 


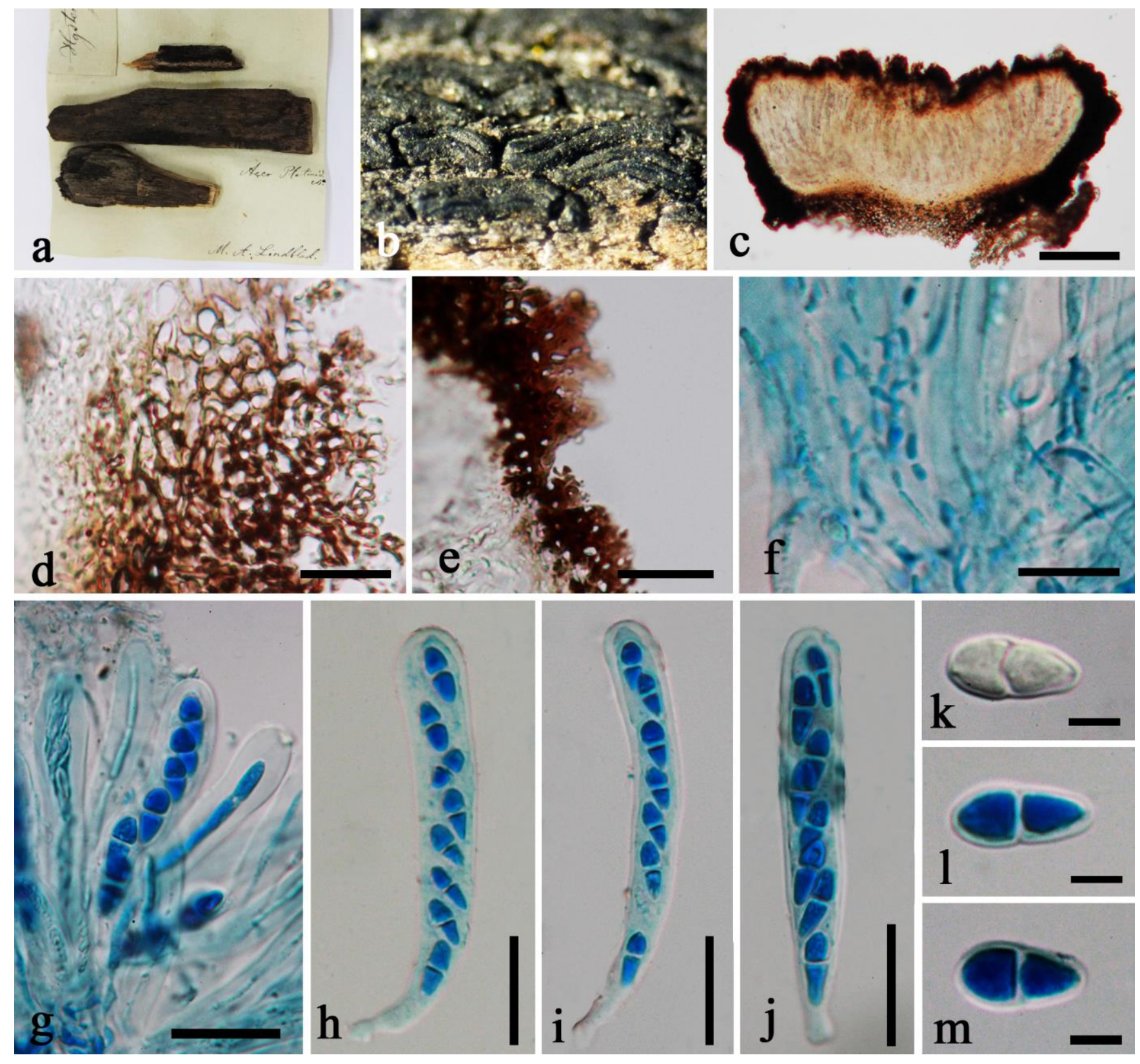

Figure 9 - Glonium lineare (S-F221568). a Herbarium label and specimen. b Ascomata on substrate. c Vertical section through ascoma. d, e Peridium. f Pseudoparaphyses. g Immature and mature asci. $\mathrm{h}-\mathrm{j}$ Asci. $\mathrm{k}-\mathrm{m}$ Ascospores. Note: $\mathrm{f}, \mathrm{g}-\mathrm{j}, \mathrm{l}, \mathrm{m}$ stained in lactophenol cotton blue. Scale bars: $\mathrm{c}=100 \mu \mathrm{m}, \mathrm{d}, \mathrm{e}, \mathrm{g}-\mathrm{j}=20 \mu \mathrm{m}, \mathrm{f}=10 \mu \mathrm{m}, \mathrm{k}-\mathrm{m}=5 \mu \mathrm{m}$.

Hysteriales Lindau, in Engler \& Prantl, Nat. Pflanzenfam., Teil. I (Leipzig) 1(1): 265 (1896)

Hysteriaceae Chevall. [as 'Hysterineae'], Fl. gén. env. Paris (Paris) 1: 432 (1826)

The family Hysteriaceae (Hysteriales) was established by Chevallier (1826). Members have a specialized ascomata termed the hysterothecium (Clements 1909). Typically, with a thick threelayered peridium, composed of small pseudoparenchymatous cells, the outer layer heavily encrusted with pigment and often longitudinally striated on the surface, the middle layer lighter in pigmentation and the inner layer distinctly thin-walled, pallid and compressed (Barr 1987b). Several authors have treated this family (Nannfeldt 1932, Gäumann 1949, Zogg 1962, von Arx \& Müller 1975, Kirk et al. 2001, Eriksson 2006, Boehm 2009, Lumbsch \& Huhndorf 2010). Boehm et al. (2009a, b) include the coelomycetous pycnidial states (e.g. Aposphaeria-like, Hysteropycnis) and dematiaceous hyphomycetous asexual morphs in the family (e.g. Coniosporium). Currently, the family Hysteriaceae consists of 14 genera (Wijayawardene et al. 2018). 
Gloniopsis De Not., G. bot. ital. 2(7-8): 12, 23 (1847)

Saprobic on dead wood. Sexual morph: hysterothecia, carbonaceous, black, scattered, superficial, longitudinal, slit at the median, erumpent to superficial on a brown felt-like subiculum, oval or subglobose. Peridium charcoal-like, carbonaceous, comprising several layers of brown to dark brown. Hamathecium comprising hypha-like, septate pseudoparaphyses, embedded in a gelatinous matrix. Asci 8-spored, bitunicate, cylindric-clavate, with a short furcate pedicel. Ascospores 2-seriate, muriform, hyaline or slightly reddish in age, obovoid, slightly constricted at the transverse septa, with a gelatinous sheath. Asexual morph: Undetermined.

Type species - Gloniopsis praelonga (Schwein.) Underw. \& Earle [as 'praelongum']

Notes - The history of genus Gloniopsis was given in Boehm et al. (2009a, b). It is characterized by hyaline to yellow dictyospores, curved, in outline obovoid, ends obtuse to sub- to acuminate, multi-septate, with one or more longitudinal septa, constricted at the first-formed septum, sometimes constricted at additional septa, gelatinous sheath (dissipates with age) (Boehm et al. 2009b). De Notaris (1847) originally did not designate a type for the genus Gloniopsis. Therefore, Clements \& Shear (1931) selected G. decipiens as the lectotype, following Höhnel (1918). Zogg (1962) considered G. decipiens a doubtful species and proposed G. praelonga as the type species and designated a specimen which he regarded as a specific synonym of G. decipiens, due to lack of identifiable material in the original lectotype. Although the genus Gloniopsis shows affinities to the genus Hysterographium, with a specific association between G. smilacis and $H$. mori, and another between $G$. praelonga and $H$. subrugosum, molecular data indicated that Gloniopsis is polyphyletic but not as broad as Hysterographium, indicating perhaps that pigmentation preceded the loss of pigmentation in this group of fungi. Based on morphology and molecular phylogenetic analyses Gloniopsis is placed in Hysteriaceae (Boehm et al. 2009b, Wijayawardene et al. 2014a, Thambugala et al. 2016).

Gloniopsis praelonga (Schwein.) Underw. \& Earle [as 'praelongum'], Bull. Alabama Agricultural Experiment Station 80: 196 (1897)

三 Hysterium praelongum Schwein., Trans. Am. phil. Soc., New Series 4(2): 244 (1832) [1834]

Index Fungorum number: IF102067; Facesoffungi number: FoF04624

Saprobic on dead wood. Sexual morph: Ascomata $165-240 \mu \mathrm{m}$ high $\times 165-300 \mu \mathrm{m}$ diam. $(\bar{x}$ $=210 \times 245 \mu \mathrm{m}, \mathrm{n}=20$ ), hysterothecia, carbonaceous, black, scattered, superficial, longitudinal slit at the center, erumpent to superficial on a brown felt-like subiculum, oval or subglobose. Peridium 40-80 $\mu \mathrm{m}$ thick at the sides, charcoal-like, carbonaceous, comprising several layers of brown to dark brown, pseudoparenchymatous cells. Hamathecium comprising $0.5-1.5 \mu \mathrm{m}$ wide, hypha-like, septate pseudoparaphyses, embedded in a gelatinous matrix. Asci $78-90 \times 14-18 \mu \mathrm{m}(\bar{x}=83 \times 16$ $\mu \mathrm{m}, \mathrm{n}=15), 8$-spored, bitunicate, cylindric-clavate, with a short furcate pedicel. Ascospores 16-21 $\times 8-11.5 \mu \mathrm{m}(\bar{x}=18.5 \times 9.5 \mu \mathrm{m}, \mathrm{n}=30), 2$-seriate, muriform, hyaline or slightly reddish in age, obovoid, with 5-7 transverse septa, 1-2(-4) longitudinal septa, slightly constricted at the transverse septa, with a gelatinous sheath. Asexual morph: Undetermined.

Material examined - USA, Florida, Winter Park, 12 January 1945, C.L. Shear (S-F53411).

Hysterocarina H. Zogg, Ber. schweiz. bot. Ges. 59: 42 (1949)

Saprobic on old wood of Eucalyptus sp. Sexual morph: Ascomata hysterothecial, coriaceous, hardly erumpent, dark brown to black, longitudinal to host surface, flat or slightly convex on top, gregarious, subglobose to globose, immersed to semi-immersed, with a central ostiole. Ostiole brown to back, periphysate. Peridium composed of cells of textura angularis. Hamathecium comprising numerous, filiform, hypha-like, septate pseudoparaphyses. Asci 8-spored, cylindrical, bitunicate, rounded apex, short to mostly long-pedicellate, arising from the ascoma base. Ascospores overlapping uniseriate, ellipsoidal, dark brown, muriform, smooth-walled, with mucilaginous sheath, constricted at the septa, thick-walled. Asexual morph: Undetermined.

Type species - Hysterocarina paulistae H. Zogg 

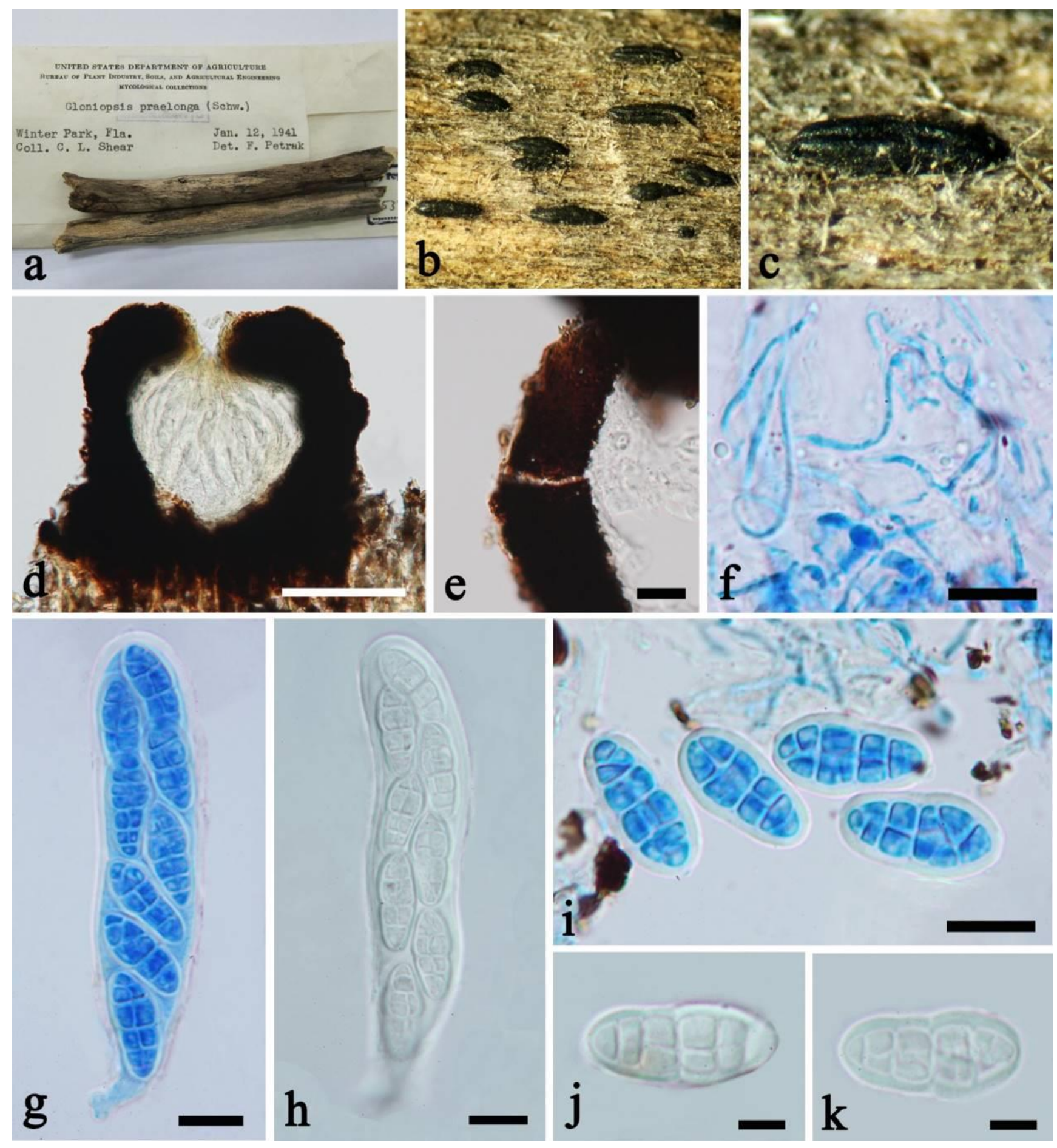

Figure 10 - Gloniopsis praelonga (S-F53411). a Herbarium label and specimen. b Ascomata on substrate. c Close up of ascoma on substrate. d Vertical section through ascoma. e Peridium. f Pseudoparaphyses. g-h Mature asci. i-k Ascospore. Note: f, g, i stained in lactophenol cotton blue. Scale bars: $\mathrm{d}=100 \mu \mathrm{m}, \mathrm{e}, \mathrm{i}=20 \mu \mathrm{m}, \mathrm{f}-\mathrm{h}=10 \mu \mathrm{m}, \mathrm{j}, \mathrm{k}=5 \mu \mathrm{m}$.

Notes - Zogg (1949) introduced the genus Hysterocarina with Hysterocarina paulistae $\mathrm{H}$. Zogg as the type species, which is currently the only species in this genus (Index Fungorum 2018). The type species was found on old wood of Eucalyptus sp. in Brazil. Hysterocarina was accepted in Hysteriaceae, Hysteriales, Dothideomycetes by Zogg (1962) and Boehm et al. (2009b) based on morphology. This placement in Hysteriaceae has been confirmed (Lumbsch \& Huhndorf 2010, Wijayawardene et al. 2014). The description and illustration of Hysterocarina paulistae (ZT Myc 1492, holotype) are provided here. There is no report of an asexual morph and no sequence data are 
available in NCBI database 2018 (http://www.ncbi.nlm.nih.gov/). Sampling of fresh specimens and molecular studies would help to confirm its placement.

Hysterocarina paulistae H. Zogg, Ber. schweiz. bot. Ges. 59: 42 (1949)

Fig. 11

Index Fungorum number: IF298858; Facesoffungi number: FoF04625

Saprobic on old wood of Eucalyptus sp. Sexual morph: Ascomata 260-340 $\mu \mathrm{m}$ high $\times 180$ $320 \mu \mathrm{m}$ diam. $(\bar{x}=290 \times 240 \mu \mathrm{m}, \mathrm{n}=10)$, hysterothecial, coriaceous, dark brown to black, longitudinal to host surface, flat or slightly convex on top, gregarious, subglobose to globose, immersed to semi-immersed, with a ostiole. Ostiole central, brown to back, periphysate. Peridium 30-60 $\mu \mathrm{m}$ thick at the sides, composed of cells of textura angularis cells, comprising two layers, outer layer black, thick-walled, inner layer comprising 3-5 cell layers, light brown, reddish brown to hyaline, thin-walled. Hamathecium comprising numerous, $1.5-2.5 \mu \mathrm{m}$ wide, filiform, hypha-like, septate, pseudoparaphyses. Asci 110-195 × 12-20 $\mu \mathrm{m}(\bar{x}=145 \times 15, \mathrm{n}=15), 8$-spored, bitunicate, cylindrical with rounded apex, short to mostly long-pedicellate, arising from the ascoma base. Ascospores $19-25 \times 8-11 \mu \mathrm{m}(\bar{x}=22 \times 9, \mathrm{n}=20)$ without sheath, $22-28 \times 10-15 \mu \mathrm{m}(\bar{x}=24 \times$ $13, \mathrm{n}=20$ ) with sheath, overlapping uniseriate, ellipsoidal, dark brown, multi-celled, smoothwalled, with 3-4 transverse and 1-3 vertical septa, constricted at the septa, thick-walled. Asexual morph: Undetermined.

Material examined - BRAZIL, Campinas, S. Paulo, Mato Dentro, on Eucalyptus sp. (Myrtaceae), 15 April 1947, H. Zogg (ZT Myc 1492, holotype).

Hysteroglonium Rehm ex Lindau, in Engler \& Prantl, Nat. Pflanzenfam., Teil. I (Leipzig) 1(1): 272 (1896)

Saprobic on wood. Sexual morph: Ascomata hysterothecia, superficial, longitudinal to host surface, straight, flat or convex on top, black, solitary, scattered, slightly shiny, semi-immersed, becoming superficial. Asci 8-spored, bitunicate, subcylindrical, apically rounded. Ascospores ellipsoid, rounded at both sides, hyaline, guttulate, aseptate, finally becoming pseudo-triseptate. Asexual morph: Undetermined.

Type species - Hysteroglonium ovatum (Cooke) Lindau

Notes -The genus Hysteroglonium was established with $H$. ovatum as the type species. The genus comprises two species epithets (Index Fungorum 2018). Cultures and sequences are unavailable (GenBank 2018) and fresh specimens and isotypes should be designated. Cooke (1883) described Hysterium ovatum (type) on old oak stumps as follows: Sexual morph; Ascomata superficial, longitudinal, straight. Asci are subcylindrical. Ascospores 15-18 $\times 8 \mu \mathrm{m}$, sublanceolatis, rounded at both sides, hyaline, guttulate, finally becoming pseudo-triseptate. We reexamined the syntype specimen K(M) 164027, but it was in poor condition. Thus, we were unable to find the hamathecium, asci or ascospores, only ascomata were present (Fig. 12). Asci and ascospores were redrawn in Fig. 13.

Hysteroglonium ovatum (Cooke) Lindau, in Engler \& Prantl, Nat. Pflanzenfam., Teil. I (Leipzig) 1(1): 272 (1896)

三 Hysterium ovatum Cooke, Grevillea 11(no. 59): 107 (1883)

Figs 12, 13

Index Fungorum number: IF431718; Facesoffungi number: FoF04626

Saprobic on wood. Sexual morph: Ascomata $69-157 \mu \mathrm{m}$ high $\times 135-280 \mu \mathrm{m}$ diam., $(\bar{x}=105$ $\times 180, \mathrm{n}=10$ ), hysterothecia, longitudinal to host surface, straight, flat or convex on top, black, solitary, scattered, slightly shiny, semi-immersed, becoming superficial. Peridium 35-65 $\mu \mathrm{m}$ thick at the sides, outer layer black, dark brown to reddish brown, inner layer hyaline, composed of textura angularis cells, hamathecium, asci and ascospores absent. Asexual morph: Undetermined.

Material examined - USA, South Carolina, on wood, H.W. Ravenel 2291 (ex herb. M.C. Cooke) (K(M) 164027, syntype). 

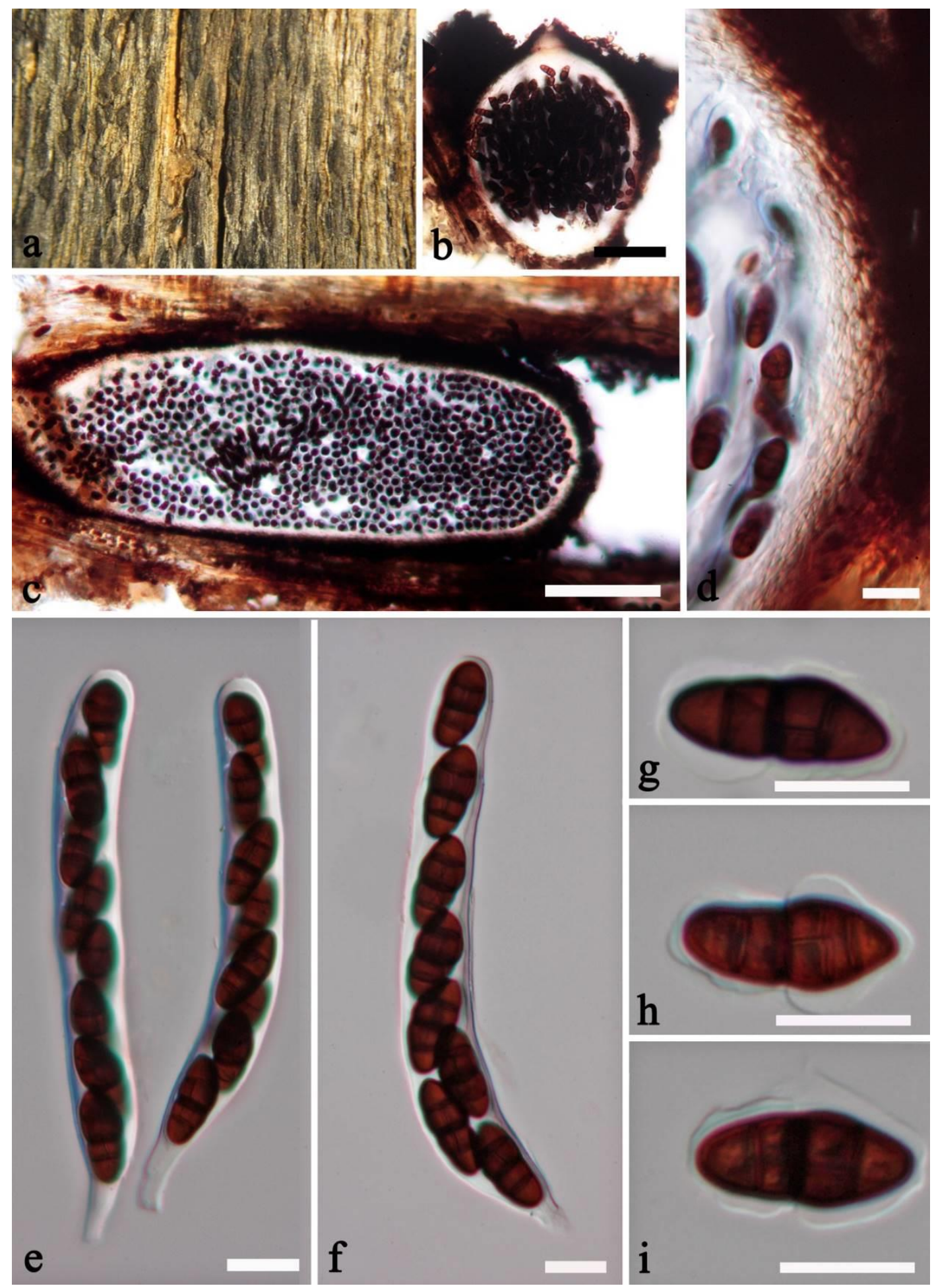

Figure 11 - Hysterocarina paulistae (ZT Myc 1492, holotype). a Ascomata on the host surface. b Vertical section through ascoma. c Longitudinal section through ascoma. d Peridium. e, f Asci with ascospores. $\mathrm{g}-\mathrm{i}$ Ascospores with sheath. Scale bars: $\mathrm{b}=300 \mu \mathrm{m}, \mathrm{c}=200 \mu \mathrm{m}, \mathrm{d}=30 \mu \mathrm{m}, \mathrm{e}, \mathrm{f}=$ $20 \mu \mathrm{m}, \mathrm{g}-\mathrm{i}=15 \mu \mathrm{m}$.

Ostreichnion Duby, Mém. Soc. Phys. Hist. nat. Genève 16(1): 33 (1861) [1862]

Saprobic on wood. Sexual morph: Ascomata hysterothecial, semi-immersed to superficial, bases attached to substrate, conchate to nearly dolabrate, black, fragile fruitbodies, not shining, rough with horizontal striation, occasionally triradiate, apex compressed along length, opening by long slit, subiculum, solitary to aggregated. Exciple composed of cells of textura intricata, charcoal-like, carbonaceous, dark brown to reddish brown. Hamathecium comprising numerous, 
filiform, hypha-like, septate, branched and anastomosing pseudoparaphyses, in a gelatinous matrix. Asci 8-spored, clavate to cylindrical, bitunicate, with thickened and rounded apex, short to mostly long-pedicellate, with an ocular chamber, arising from the ascoma base. Ascospores uniseriate, yellowish or pale brown to dark brown, broadly cylindrical to fusiform, occasionally ellipsoidal, tapering to rounded ends, obvious septum at median, thickened and dark, slightly constricted at septum, secondary septa cutting off end cells, tertiary septa intermediate and often one or two in end cells, transverse septa, longitudinal septa, with apical plug, wall surface somewhat roughened and irregular. Asexual morph: Undetermined.

Type species - Ostreichnion sassafras (Schwein.) M.E. Barr

= Ostreichnion americanum Duby, Mém. Soc. Phys. Hist. nat. Genève 16(1): 34 (1862)
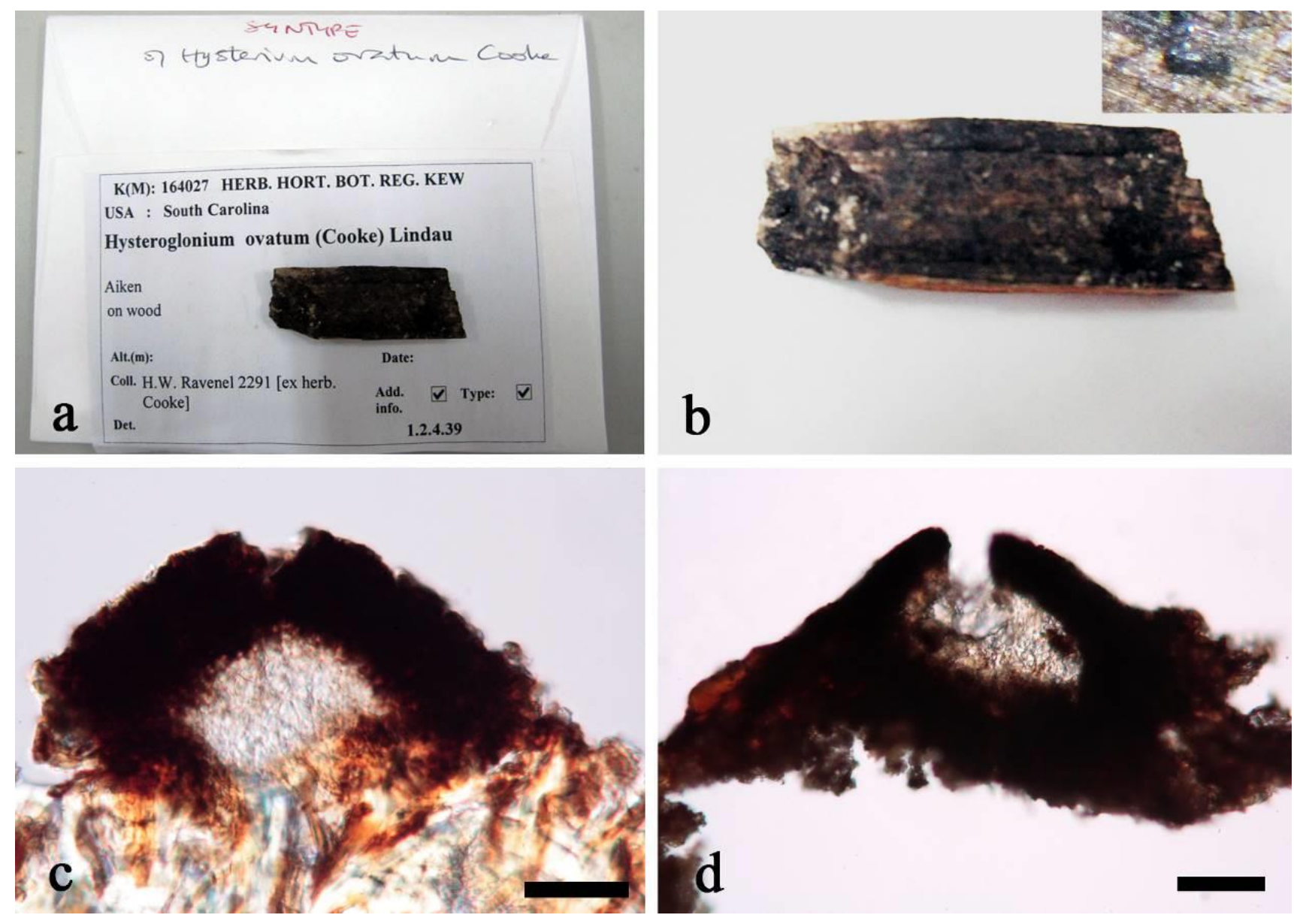

Figure 12 - Hysteroglonium ovatum (K(M) 164027, syntype). a Herbarium label and specimen. b Host and close up of ascoma on host. c, d Vertical sections through an ascomata. Scale bars: c, $d=50 \mu \mathrm{m}$.

Notes - The genus Ostreichnion was established by Duby (1862) for two species, $O$. americanum as type species and $O$. europaeum. Ostreichnion was studied by several authors (Saccardo 1883, Rehm 1886, Clements \& Shear 1931, Zogg 1962), and reappraised by Barr (1975). Ostreichnion americanum was later consigned to the earlier name O. sassafras (Barr 1975). Boehm et al. (2009b) transferred the genus Ostreichnion from Mytilinidiaceae (Barr 1975) to Hysteriaceae based on sequence data derived from O. curtisii (CBS 198.34) and O. sassafras (CBS 322.34), which were deposited by Lohman in 1934. Barr (1975) and Boehm et al. (2009b) included $O$. curtisii in the genus and provided a key to the species. Based on combined analysis of SSU, LSU, TEF1 and RPB2 by Boehm et al. (2009a, b) Ostreichnion curtisii was placed quite distant from $O$. sassafras and shared a subclade with Hysterium. Ascospores of $O$. curtisii differ from $O$. sassafras and $O$. nova-caesariense by having 1 septum below the middle while the other two species are 
dictyospores (Barr 1975). We speculate that Ostreichnion curtisii is likely to be the species in Hysterium that was earlier named as Hysterium curtisii by Duby (1862). Jayasiri et al. (2018) proposed Hysterium curtisii as current name for Ostreichnion curtisii. Fresh samples, epitypification and molecular studies are required to re-evaluate the classification of Ostreichnion species.

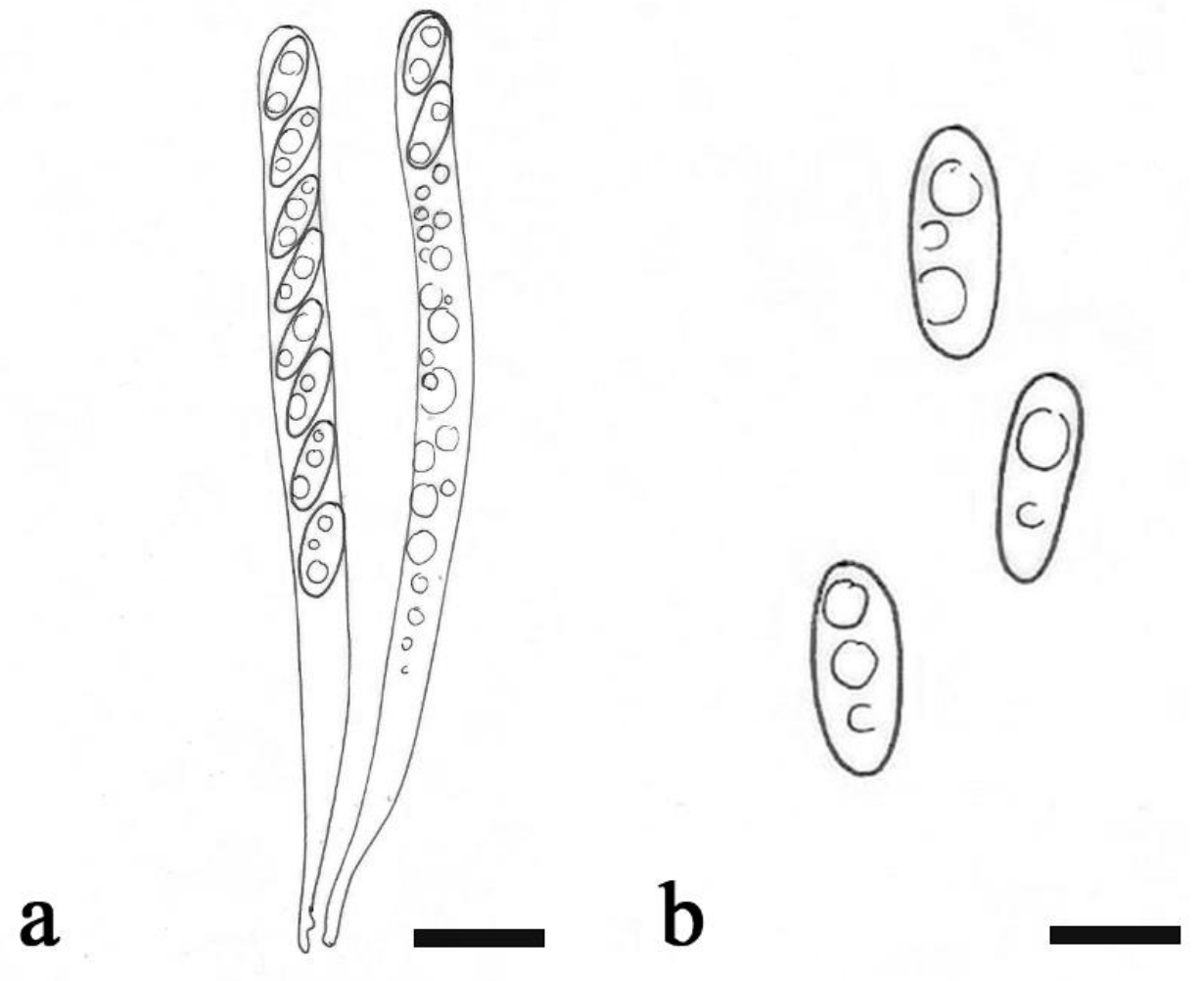

Figure 13 - Hysteroglonium ovatum (redrawn from picture in herbarium package (K(M) 164027, syntype). a Asci with ascospores. b Ascospores. Scale bars: $a=20 \mu \mathrm{m}, \mathrm{b}=10 \mu \mathrm{m}$.

Ostreichnion sassafras (Schwein.) M.E. Barr, Mycotaxon 3(1): 83 (1975)

三Lophium sassafras Schwein., Trans. Am. phil. Soc., New Series 4(2): 240 (1832) [1834]

$\equiv$ Mytilinidion sassafras (Schwein.) H. Zogg [as 'Mytilidion'], Beitr. Kryptfl. Schweiz 11(no. 3): 117 (1962)

= Ostreichnion americanum Duby, Mém. Soc. Phys. Hist. nat. Genève 16(1): 34 (1861) [1862]

= Ostreion americanum (Duby) Sacc., Syll. fung. (Abellini) 2: 765 (1883)

Index Fungorum number: IF319047; Facesoffungi number: FoF04627

Saprobic on wood. Sexual morph: Ascomata 690-970 $\mu \mathrm{m}$ high $\times 835-1140 \mu \mathrm{m}$ diam., hysterothecial, semi-immersed to superficial, bases attached to substrate, conchate to nearly dolabrate, black, not shining, rough with striation, horizontally striate, occasionally triradiate, apex compressed along length, opening by long slit, subiculum, solitary to aggregated. Exciple 210-330 $\mu \mathrm{m}$ thick at the sides, composed of textura intricate cells, charcoal-like, carbonaceous, dark brown to reddish brown. Hamathecium comprising 1.5-2.5 $\mu \mathrm{m}$ wide, filiform, hypha-like, septate, numerous, branched and anastomosing pseudoparaphyses, in a gelatinous matrix. Asci 300-360 $\times$ $37-50 \mu \mathrm{m}(\bar{x}=325 \times 44, \mathrm{n}=20), 8$-spored, bitunicate, clavate to cylindrical, with thickened and 
rounded apex, short to mostly long-pedicellate, with an ocular chamber, arising from the ascoma base. Ascospores $92-175 \times 28-50 \mu \mathrm{m}(\bar{x}=120 \times 36, \mathrm{n}=30)$, uniseriate, yellowish or pale brown to dark brown, broadly cylindrical to fusiform, occasionally ellipsoidal, tapering to rounded ends, obvious median septum, thickened and dark, slightly constricted at septum, secondary septa cutting off end cells, tertiary septa intermediate and often one or two in end cells, 1-7 and up to 27 transverse septa, 1-5 longitudinal septa, with apical plug, wall surface somewhat roughened and irregular. Asexual morph: Undetermined.

Material examined - USA, Florida, Ocala, 1897-1898, R. Thaxter, Reliquiae Farlowianae (NY 626).
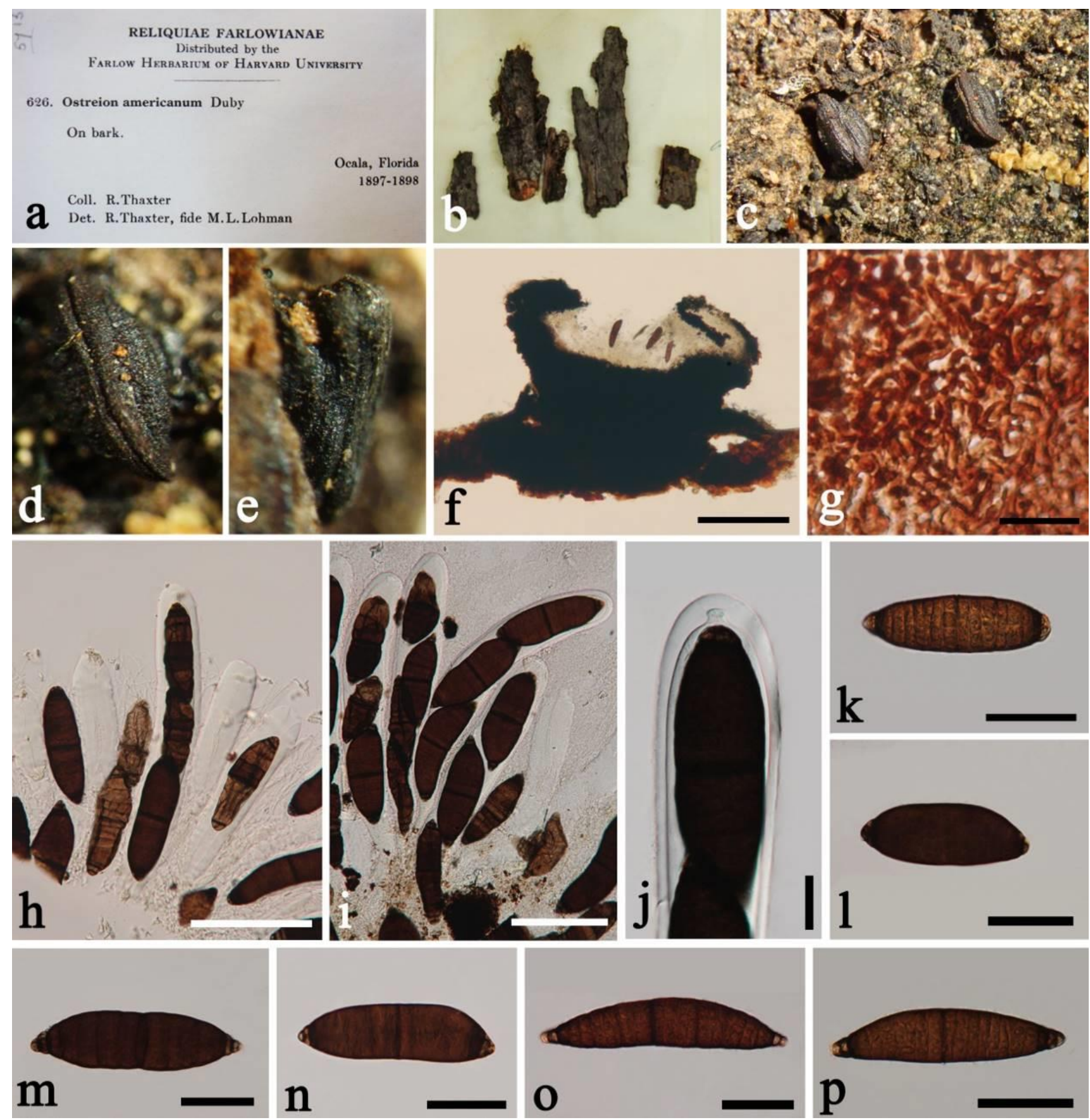

Figure 14 - Ostreichnion sassafras (NY 626). a Details of herbarium material. b Host substrate. c Ascomata on host (top view). d Close up of ascoma on host (top view). e Close up of ascoma on host (side view). f Vertical section through an ascoma. g Peridium. h, i Asci. j Ascus with an ocular chamber. $\mathrm{k}-\mathrm{p}$ Ascospores. Scale bars: $\mathrm{f}=300 \mu \mathrm{m}, \mathrm{g}=20 \mu \mathrm{m}, \mathrm{h}, \mathrm{i}=100 \mu \mathrm{m}, \mathrm{j}=20 \mu \mathrm{m}, \mathrm{k}-\mathrm{p}=50$ $\mu \mathrm{m}$. 

[95 repr.] (1909)

Epiphytic or saprobic on leaves. Sexual morph: Ascostromata superficial, brown to black, rough, scattered, solitary on lower surface of leaf, hemispherical, pulvinate, surrounded by brown mycelial network forming plectenchymatous tissue, subiculum, multi-loculate each with single ascus and without obvious separating wall layer. Asci 8-spored, bitunicate, globose to subglobose, short pedicellate, apically rounded, with indistinct ocular chamber. Ascospores crowded, muriform, ellipsoid to oblong, hyaline when immature, becoming brown at maturity, obtuse at both ends, slightly constricted at middle septum, smooth-walled. Asexual morph: Undetermined.

Type species - Dictyonella erysiphoides (Rehm) Höhn.

Notes - Dictyonella was established by Höhnel (1909a). The genus consists of seven species epithets (Index Fungorum 2018), with Dictyonella erysiphoides as the type species. Dictyonella has been subjected to few studies and there is no recent account. In this study we exclude Dictyonella from Saccardiaceae and place it in Myriangiales, genus incertae sedis based on morphology in which ascostromata are pulvinate, asci are irregularly arranged in one or more layers in locules and have minute pedicels and indistinct ocular chambers. Representative species, particularly the type species, need to be recollected for molecular study to clarify its natural classification.

Dictyonella erysiphoides (Rehm) Höhn. [as 'erisyphoides'], Sber. Akad. Wiss. Wien, Math.-naturw. Kl., Abt. 1 118: 369 [95 repr.] (1909)

三 Cookella erysiphoides Rehm, Hedwigia 40: 169 (1901)

Fig. 15

Index Fungorum number: IF163806; Facesoffungi number: FoF04628

Epiphytic on lower surface of leaves. Sexual morph: Ascostromata 60-145 $\mu \mathrm{m}$ high $\times 185$ $305 \mu \mathrm{m}$ diam. $(\bar{x}=105 \times 240 \mu \mathrm{m}, \mathrm{n}=15)$, superficial, black, rough, sub-carbonaceous, scattered, solitary on lower surface of leaf, hemispherical, pulvinate, surrounded by brown mycelial network forming plectenchymatous tissue, subiculum, ostiole not seen. Hamathecium lacking paraphyses. Asci 35-60 $\times 25-45 \mu \mathrm{m}(\bar{x}=52 \times 35 \mu \mathrm{m}, \mathrm{n}=15), 8$-spored, bitunicate, globose to subglobose, short pedicellate or apedicellate, apically rounded with indistinct ocular chamber. Ascospores 22$30 \times 8-12 \mu \mathrm{m}(\bar{x}=25 \times 10 \mu \mathrm{m}, \mathrm{n}=20)$, crowded, muriform, ellipsoid to oblong, hyaline when immature, becoming brown at maturity, obtuse at both ends, with 3-5 transverse septa and 4-7 longitudinal septa, slightly constricted at middle septum, smooth-walled. Asexual morph: Undetermined.

Material examined - BRAZIL, Rio de Janeiro, Tijuca, on Coccoloba sp. (Polygonaceae), November 1897, E. Ule (S-F12211, holotype).

Mytilinidiales E. Boehm, C.L. Schoch \& Spatafora, Mycol. Res. 113(4): 468 (2009)

Mytilinidiaceae Kirschst. [as 'Mytilidiaceae'], Verh. bot. Ver. Prov. Brandenb. 66: 28 (1924)

Possible synonyms:

Lophiaceae H. Zogg ex Arx \& E. Müll., Stud. Mycol. 9:60. 1975.

Mytilinidiaceae consists of ten genera (Wijayawardene et al. 2018). They are characterized by persistent, fragile, carbonaceous ascomata, which range from globoid to obovoid to strongly laterally compressed, erect oyster- or bivalve shell-shaped (conchate), or hatchet-shaped (dolabrate) structures, in some species forming a longitudinal keel or cristate apex (Barr 1990). Mytilinidiaceous fungi possess a thin-walled, prosenchymatous peridium enclosing a hamathecium of narrow trabeculate pseudoparaphyses, borne in a gel matrix, which are often sparse to lacking at maturity (Barr 1987b, 1990, Zogg 1962). Bitunicate asci are borne in a basal, rarely lateral orientation within the centrum, and contain eight, rarely four, ascospores, overlapping 1-2-seriate, or in 1 or 2 fascicles. Ascospores are diverse in the Mytilinidiaceae and range from scolecospores to didymospores, phragmospores or dictyospores, hyaline, soon turning yellow to dark brown, and generally showing bipolar symmetry in outline (Barr 1990). The history of Mytilinidiaceae was discussed in Boehm et al. (2009a, b) and Hyde et al. (2013). 
Actidium Fr., Observ. mycol. (Havniae) 1: 190 (1815)

Saprobic on dead wood. Sexual morph: Ascomata hysterothecia, carbonaceous, 2-4projections, not star-shaped to star-shaped or stellate, black, superficial, solitary or gregarious, thick-walled, distinctly navicular in outline, bearing a pronounced longitudinal slit, ellipsoid to greatly elongated. Peridium charcoal-like, carbonaceous, black, composed of small pseudoparenchymatous cells. Asci 8-spored, bitunicate, overlapping 1-2-seriate. Ascospores 1septate, small, thin-walled, smooth or delicately longitudinally striate, rounded at the apex. Asexual morph: Undetermined.

Type species - Actidium hysterioides Fr.

Notes - Actidium was introduced by Fries (1815) to accommodate A. hysterioides as the type species on decorticated wood of Pinus. The genus has 15 species epithets, but 13 species are listed under genus Actidium (Index Fungorum 2018). There are no sequence data of any Actidium species in NCBI database (2018). Re-collection, isolation and sequencing are required to define the phylogenetic placement, especially of the type species which has not been sequenced yet. The asexual morph has not been reported. We re-examined a specimen from S (F203614). However, although ascomata were present on the host surface, asci and ascospores could not be found (Fig. 16). Appearance of ascomata on host surface, asci and ascospores were redrawn in Fig. 17.
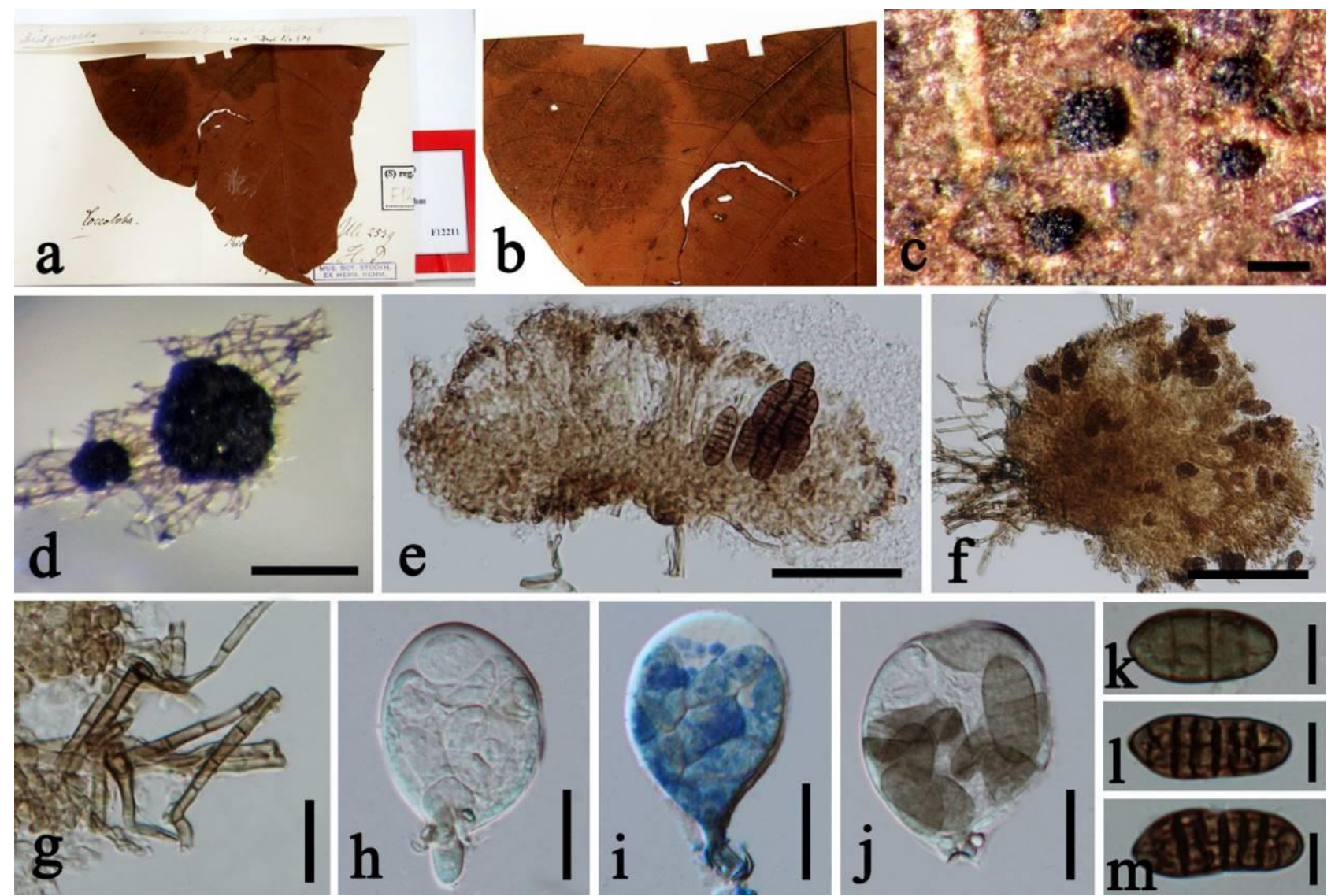

Figure 15 - Dictyonella erysiphoides (S-F12211, holotype). a Herbarium label and specimen. b Ascomata on host. c Close up of ascomata. d Ascomata with basal hypha. e Vertical section through ascoma. f Ascoma with hyphae. g Hyphae. $\mathrm{h}-\mathrm{j}$ Asci with ascospores. Note: $\mathrm{i}$ stained in lactophenol cotton blue. $\mathrm{k}-\mathrm{m}$ Ascospores. Scale bars: $\mathrm{c}, \mathrm{f}=100 \mu \mathrm{m}, \mathrm{d}=200 \mu \mathrm{m}, \mathrm{e}=50 \mu \mathrm{m}, \mathrm{g}-\mathrm{m}=$ $20 \mu \mathrm{m}$.

Actidium hysterioides Fr., Observ. mycol. (Havniae) 2: 353 (1818)

Figs 16, 17

Index Fungorum number: IF203642; Facesoffungi number: FoF04629

Saprobic on dead Picea excelsa. Sexual morph: Ascomata hysterothecia, carbonaceous, 2-4projections to star-shaped or stellate, black, superficial, solitary, or gregarious, thick-walled, 
distinctly navicular in outline, bearing a pronounced longitudinal slit, ellipsoid to greatly elongated. Peridium charcoal-like, carbonaceous, black. Hamathecium not observed. Asci 40-50(-55) $\times 5 \mu \mathrm{m}$ (Zogg 1960), 8-spored, bitunicate, numerous, cylindrical, with apex rounded, overlapping 1-2seriate. Ascospores are 11-14 × (1.5-)2-3 $\mu \mathrm{m}$ (Zogg 1960), 1-septate, small, light olive to reddish brown, thin-walled, smooth or delicately longitudinally striate, rounded at the apex. Asexual morph: Undetermined.

Material examined - SWEDEN, Stockholm, Södermanland, Suecia, Holmia, on Picea excels (L.) H. Karst. (Pinaceae), October 1908, J. Vleugel (S-F203614).
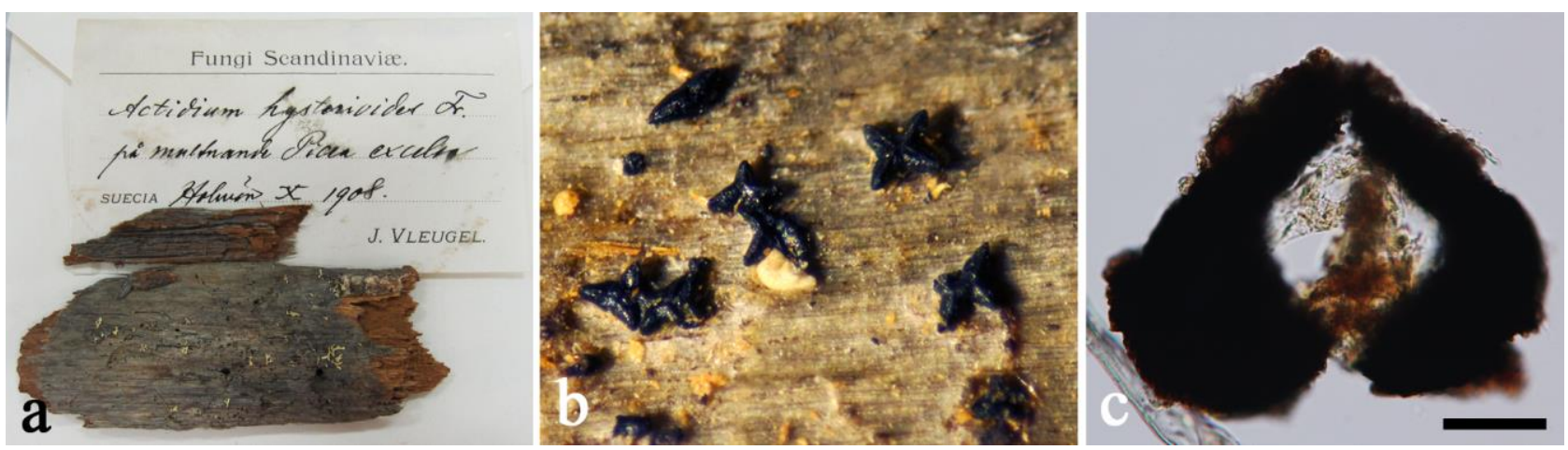

Figure 16 - Actidium hysterioides (S-F203614). a Herbarium label and specimen. b Ascomata on substrate. c Vertical section through ascoma with dry tissue in ascoma. Scale bars: $c=50 \mu \mathrm{m}$.

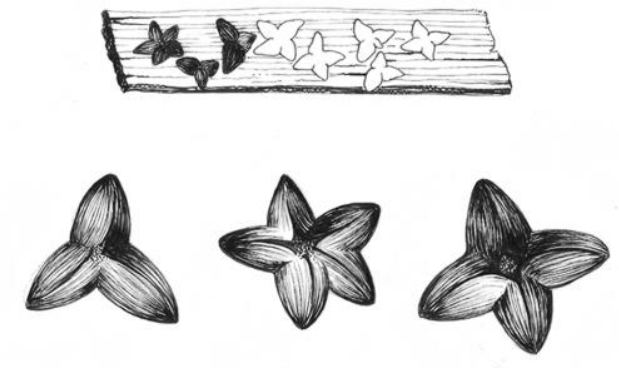

a
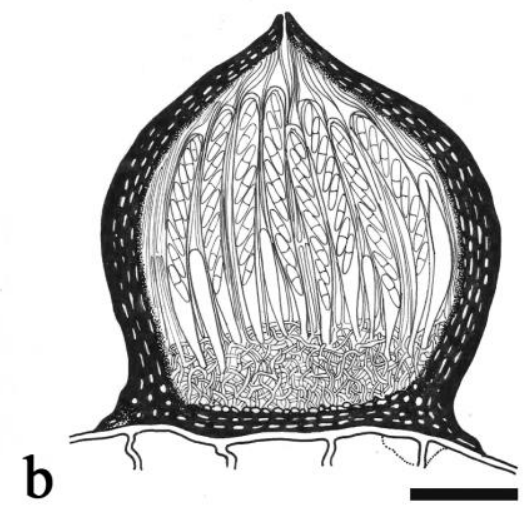

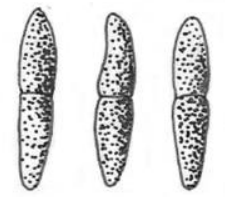

C

Figure 17 - Actidium hysterioides. a Appearance of ascomata on surface (a: redrawn from drawings of Wm. Phillips. Recd. 1906, which is the information in package of $\mathrm{K}$ specimen). b Ascoma with asci and ascospores. c Ascospores. (b, c: redrawn from Zogg 1960, Page 198, Fig. 2; and Page 202, Fig. 7(1), respectively). Scale bars: $b=20 \mu \mathrm{m}, \mathrm{c}=5 \mu \mathrm{m}$.

\section{Quasiconcha M.E. Barr \& M. Blackw., Mycologia 72(6): 1224 (1981) [1980]}

Saprobic on undigested seeds excreted in dung. Sexual morph: Ascomata superficial, carbonaceous, shiny, rough-walled, brittle, thin, bivalve shell-shaped, standing upright, elongated opening at apex, dark to reddish brown. Pseudoparaphyses not seen. Asci 8-spored, overlapping bitunicate, cylindrical and thin-walled at maturity with pedicel. Ascospores symmetric, septate, slightly constricted at the septum, broadly ellipsoid, with coarsely reticulate wall. Asexual morph: Chalara-like.

Type species - Quasiconcha reticulata M.E. Barr \& M. Blackw.

Notes - The genus Quasiconcha was established by Barr \& Blackwell (1980) and typified by Q. reticulata, and placed in Lophiaceae of the Melanommatales (Barr 1979) based on ascomata shape, thin peridium of parallel rows of cells and being saprobic on coniferous substrate. Blackwell 
\& Gilbertson (1985) revealed the asexual morph of Q. reticulata with chlamydospore and phialides forming conidia; the specimen being isolated from Arizona, USA fruiting on underground root of a dead Aleppo pine (Pinus halapensis Mill.) infected with the pine wood nematode and on root of a dead arbor vita (Thuja occidentalis L.). Boehm et al. (2009b) extracted DNA from the type, and multi genes analysis (LSU, SSU, TEF1 and RPB2) placed Quasiconcha in Mytilinidiaceae. Phylogenetic analyses show that Quasiconcha is closely related to Lophium which its fruit bodies closely resemble. However, Lophium mytilinum, produces filiform ascospores, while Quasiconcha reticulata produces reticulated didymospores.

Quasiconcha reticulata Barr \& Blackwell, Mycologia 72: 1224 (1980).

Fig. 18

Index Fungorum number: IF112608; Facesoffungi number: FoF04630

Saprobic on undigested seeds of Juniperus virginia excreted in dung of Bassariscus astatus (Lichtenstein). Sexual morph: Ascomata superficial, carbonaceous, shiny, rough-walled, brittle, thin, bivalve shell-shaped, standing upright, elongated opening at apex, dark to reddish brown, up to $520 \mu \mathrm{m}$ to $1 \mathrm{~mm}$ diameter, and $390-570 \mu \mathrm{m}$ high $(\bar{x}=760 \times 530 \mu \mathrm{m}, \mathrm{n}=5)$. Pseudoparaphyses not seen. Asci 41-47 $\mu \mathrm{m} \times 4.1-5.3 \mu \mathrm{m}$. diam. $(\bar{x}=44 \times 4.8 \mu \mathrm{m}, \mathrm{n}=5), 8$-spored, overlapping bitunicate, cylindrical and thin-walled at maturity with pedicel. Ascospores $5.6-7 \times 3.8-4.7 \mu \mathrm{m}(\bar{x}$ $=6.2 \times 4.2 \mu \mathrm{m}, \mathrm{n}=20$ ), brown, symmetric, 1-septate, slightly constricted at the septum, broadly ellipsoid, with coarsely reticulate wall. Asexual morph: Chalara-like

Material examined - USA, Texas, Austin, on undigested seeds of Juniperus virginia excreted in dung of Bassariscus astatus (Lichtenstein), Meredith Blackwell, 10 February 1967, Barr \& Blackwell (holotype).

Pleosporales Luttrell ex M.E. Barr, Prodr. Cl. Loculoasc. (Amherst): 67 (1987)

Astrosphaeriellaceae Phook. \& K.D. Hyde, in Phookamsak et al., Fungal Diversity: 10.1007/s13225-015-0352-7, [19] (2015)

This family was introduced in Phookamsak et al. (2015) and is typified by Astrosphaeriella Syd. \& P. Syd. with A. fusispora Syd. \& P. Syd. as the type species. The family is characterized by large, conical, carbonaceous ascostromata, bitunicate asci with narrowly cellular pseudoparaphyses and fusiform or obclavate, septate ascospores (Liu et al. 2011, Phookamsak et al. 2015). Recently, two genera Astrosphaeriella and Pteridiospora were accommodated in this family (Phookamsak et al. 2015, Hyde et al. 2018, Wanasinghe et al. 2018, Wijayawardene et al. 2018).

Mycopepon Boise, Syst. Ascom. 6(1): 168 (1987)

Index Fungorum number: IF25196; Facesoffungi number: FoF04631

Saprobic on decorticated wood. Sexual morph: Ascostromata solitary to gregarious, superficial, visible as black, carbonaceous, pumpkin-like in shape on the host surface, 3-5 locules, short stalked, an eccentric papillate with central ostiole. Locules globose to subglobose, sharing one ostiole. Peridium thick-walled, brittle, compose of several heavily pigmented, carbonaceous, scleroparenchymatous cells, arranged in a textura angularis to textura globulosa. Hamathecium comprising numerous, anastomosing, narrow trabeculate pseudoparaphyses, embedded in mucilaginous matrix. Asci 8-spored, bitunicate, clavate to cylindric-clavate, short-pedicellate, apically rounded, with ocular chamber. Ascospores overlapping, 1-3-seriate, brown to dark brown or reddish brown, paler at the end cells, fusiform, initially aseptate, becoming 3-septate at maturity. Asexual morph: Undetermined.

Type species - Mycopepon guianensis Boise

Notes - Boise (1994) re-examined a specimen of Pseudovalsa smithii Ellis \& Everh. (Smith 1893) and found that Mycopepon guianensis is conspecific with P. smithii. Therefore, Boise (1994) proposed a new combination of $P$. smithii under Mycopepon smithii and synonymized $M$. guianensis under M. smithii. Mycopepon was introduced as a monotypic genus by Boise (1987) to accommodate the type species $M$. guianensis, which was collected from decorticated wood in France. Mycopepon has an unusual character in forming a pumpkin-like, carbonaceous 
ascostromata with eccentric papilla, bitunicate asci with large, dark brown, septate ascospores, which is distinct from other ascomycetous taxa (Boise 1987). Boise (1987) accommodated the genus in Pleosporales and this was concurred by San Martín (1996). Kirk et al. (2008) listed the genus in Melanommataceae. Based on its unique morphological characters and phylogenetic analyses obtained from the strain of a putative species, $M$. smithii, the genus was recently accommodated in the Pleosporales genera incertae sedis (Bhattacharya et al. 2000, Pinnoi et al. 2007, Wang et al. 2007). Lumbsch \& Huhndorf (2007, 2010) and Wijayawardene et al. (2014, 2017) listed the genus in Dothideomycetes genera incertae sedis. Only four epithets are listed in Index Fungorum (2018).

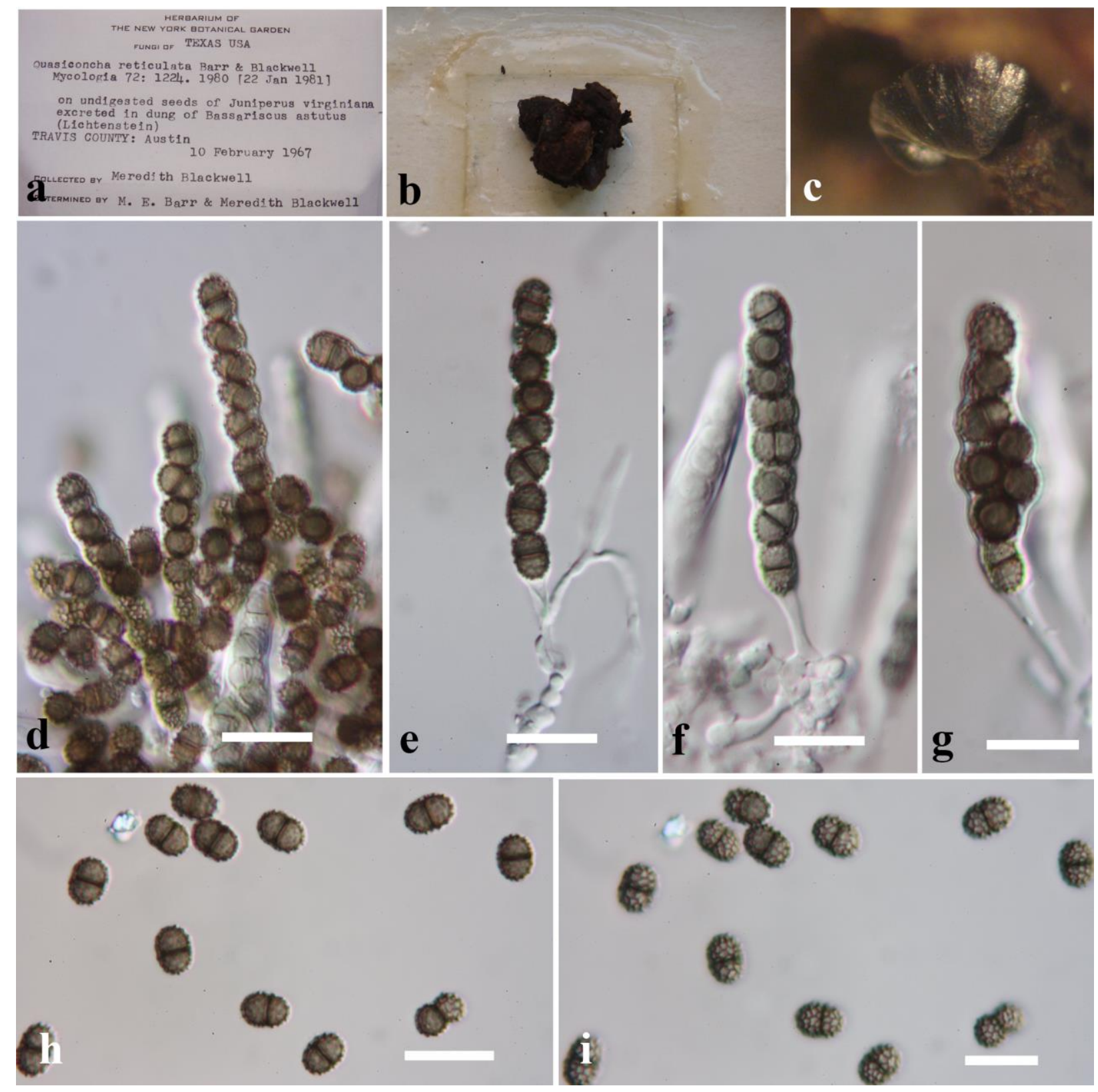

Figure 18 - Quasiconcha reticulata (holotype). a, b Herbarium label and specimen. c Appearance of mytiliniod ascoma on host surface. $\mathrm{d}-\mathrm{g}$ Asci with ascospores. $\mathrm{h}-\mathrm{i}$ Two-celled, brown, symmetric ascospores with coarsely reticulate wall. Scale bars: $\mathrm{d}-\mathrm{g}=10 \mu \mathrm{m}, \mathrm{h}, \mathrm{i}=5 \mu \mathrm{m}$.

In this study, the type specimen of Mycopepon guianensis was examined and illustrated and appears to be typical of Astrosphaeriellaceae. The asci and ascospores have the appearance of Astrosphaeriella species (Phookamsak et al. 2015). Although they are not important in defining 
orders (Liew et al. 2000), the trabeculate pseudoparaphyses are also typical of Astrosphaeriellaceae and provide evidence for inclusion in this family. Phylogenetic analyses of a combined LSU, SSU and TEF1 (data not shown) show that a representative strain, $M$. smithii (= M. guianensis) clustered within Astrosphaeriellaceae. Hence, we place the genus in the family Astrosphaeriellaceae until the generic type is epitypified and its phylogenetic affinity in the family is confirmed.

Mycopepon guianensis Boise, Syst. Ascom. 6(1): 168 (1987)

Fig. 19

Index Fungorum number: IF132140; Facesoffungi number: FoF04632

Current name: Mycopepon smithii (Ellis \& Everh.) Boise, Mycotaxon 52(1): 303 (1994)

Saprobic on decorticated wood. Sexual morph: Ascostromata 800-970 $\mu \mathrm{m}$ high, 900-1100 $\mu \mathrm{m}$ diam., solitary to gregarious, superficial, visible as black, carbonaceous, pumpkin-like in shape on the host surface, 3-5 locules, short-stalked, an eccentric papilla with central ostiole. Locules 360-660 $\mu \mathrm{m}$ high, 300-480 $\mu \mathrm{m}$ diam., globose to subglobose, sharing one ostiole. Peridium 45-70 $\mu \mathrm{m}$ wide, thick-walled, brittle, compose of several heavily pigmented, carbonaceous, scleroparenchymatous cells, arranged in a textura angularis to textura globulosa. Hamathecium comprising numerous, 0.8-2.7 $\mu \mathrm{m}$ wide, anastomosing, narrow trabeculate pseudoparaphyses, embedded in mucilaginous matrix. Asci $205-240 \times 28-38 \mu \mathrm{m}(\bar{x}=225.5 \times 32.4, \mathrm{n}=20)$, 8-spored, bitunicate, fissitunicate, clavate to cylindric-clavate, short-pedicellate, apically rounded with ocular chamber. Ascospores 58-75 $\times 13-17 \mu \mathrm{m}(\bar{x}=65.6 \times 14.5, \mathrm{n}=30)$, overlapping, $1-3$-seriate, fusiform, brown to dark brown or reddish brown, paler at the end cells, initially aseptate, becoming 3-septate at maturity, constricted at the central septum, slightly curved, rough-walled with small guttules when young, smooth-walled at maturity. Asexual morph: Undetermined.

Material examined: - FRANCE, French Guiana, ca. $15 \mathrm{~km} \mathrm{SW}$ of Saül, towards Mt. Galbao, 600-650 m., on decorticated wood, 18 January 1986, G.J. Samuels \& J. Boise 2991, (FH 00290591, Mycopepon guianensis, holotype).

Dacampiaceae Körb. [as 'Dacampieae'], Syst. lich. germ. (Breslau): 322 (1855)

The species in Dacampiaceae are lichenicolous, lichenized and saprobes (Hawksworth \& Diederich 1988, Lutzoni et al. 2004, Zhang et al. 2009b, Halici 2010, Hyde et al. 2013). Their characters are blackish, perithecioid ascomata, pseudoparenchymatous exciple, branched anastomosing pseudoparaphyses, bitunicate asci, and septate to muriform, usually brown ascospores (Hyde et al. 2013). Dacampiaceae was formerly placed in Dothideales (Eriksson \& Hawksworth 1986). Phylogenetic insights have resolved the Dacampiaceae in Pleosporales (Ertz et al. 2015a). Hyde et al. (2013) illustrated the type genus Dacampia and provided a key to genera of Dacampiaceae. The family Dacampiaceae comprises six genera (Wijayawardene et al. 2018).

Eopyrenula R.C. Harris, Michigan Bot. 12(1): 19 (1973)

Facultatively lichenized, inhabiting bark. Sexual morph: Ascomata perithecioid, semiimmersed to superficial, visible as dark spot, solitary, scattered, globose to subglobose, dark brown to black, ostiole central, with pore-like opening. Peridium thick-walled, comprising several layers of small, dark brown cells, arranged in a textura epidermoidea. Hamathecium composed of dense, narrowly cellular pseudoparaphyses, embedded in a gelatinous matrix. Asci 8-spored, bitunicate, cylindrical to cylindric-clavate, short-pedicellate, apically rounded, with well-developed ocular chamber. Ascospores overlapping 1-2-seriate, phragmosporous, brown to dark brown, paler at the end cells, ellipsoidal to fusiform, septate, constricted at the septa, mostly larger in the middle cells, smooth to rough-walled, with minute guttules. Asexual morph: Reported as coelomycetes, pycnidial, frequently accompanied by colourless, curved, filiform, simple microconidia and brown, 1- or more septate macroconidia (Harris 1973, Hyde et al. 2013).

Type species - Eopyrenula leucoplaca (Wallr.) R.C. Harris

Notes - Eopyrenula was introduced by Harris (1973) with E. leucoplaca as the type species. The genus has six species epithets (Index Fungorum 2018). Taxonomic classification of Eopyrenula has been changed by subsequent authors (Harris 1975, 1995, Barr 1976, 1979, 1983, Aptroot 1998, 
2012, Hyde et al. 2013, Jaklitsch et al. 2016, Lücking et al. 2016). The genus was treated in Pyrenulaceae (Eurotiomycetes) by Harris (1975), Aptroot (2012) and Jaklitsch et al. (2016). Subsequently, Eopyrenula was accepted in Dacampiaceae (Lumbsch \& Huhndorf 2010, Hyde at al. 2013, Wijayawardene et al. 2014, Ertz et al. 2015a). Recently, Eopyrenula was listed in Pezizomycotina genera incertae sedis by Lücking et al. (2016) and Wijayawardene et al. (2018), as most genera in Dacampiaceae are lichenicolous fungi. However, we accept Eopyrenula in Dacampiaceae on the basis of their morphology defined by uni-locular, perithecioid ascomata, branched and anastomosing pseudoparaphyses, elongate-clavate to short-cylindrical asci with shortpedicellate, 1-2-seriate, phragmosporous, brown to dark brown, fusiform ascospores. Moreover, Eopyrenula is morphologically similar to the type genus (Dacampia) of Dacampiaceae as presented in Hyde et al. (2013) but ascospores of Eopyrenula are phragmospores while Dacampia are muriform (but transverse septa may be missing when immature). No molecular data are available for Eopyrenula. Thus, we illustrate a representative specimen of E. leucoplaca. Cultures and fresh collections along with molecular data are required to confirm placement of the genus.

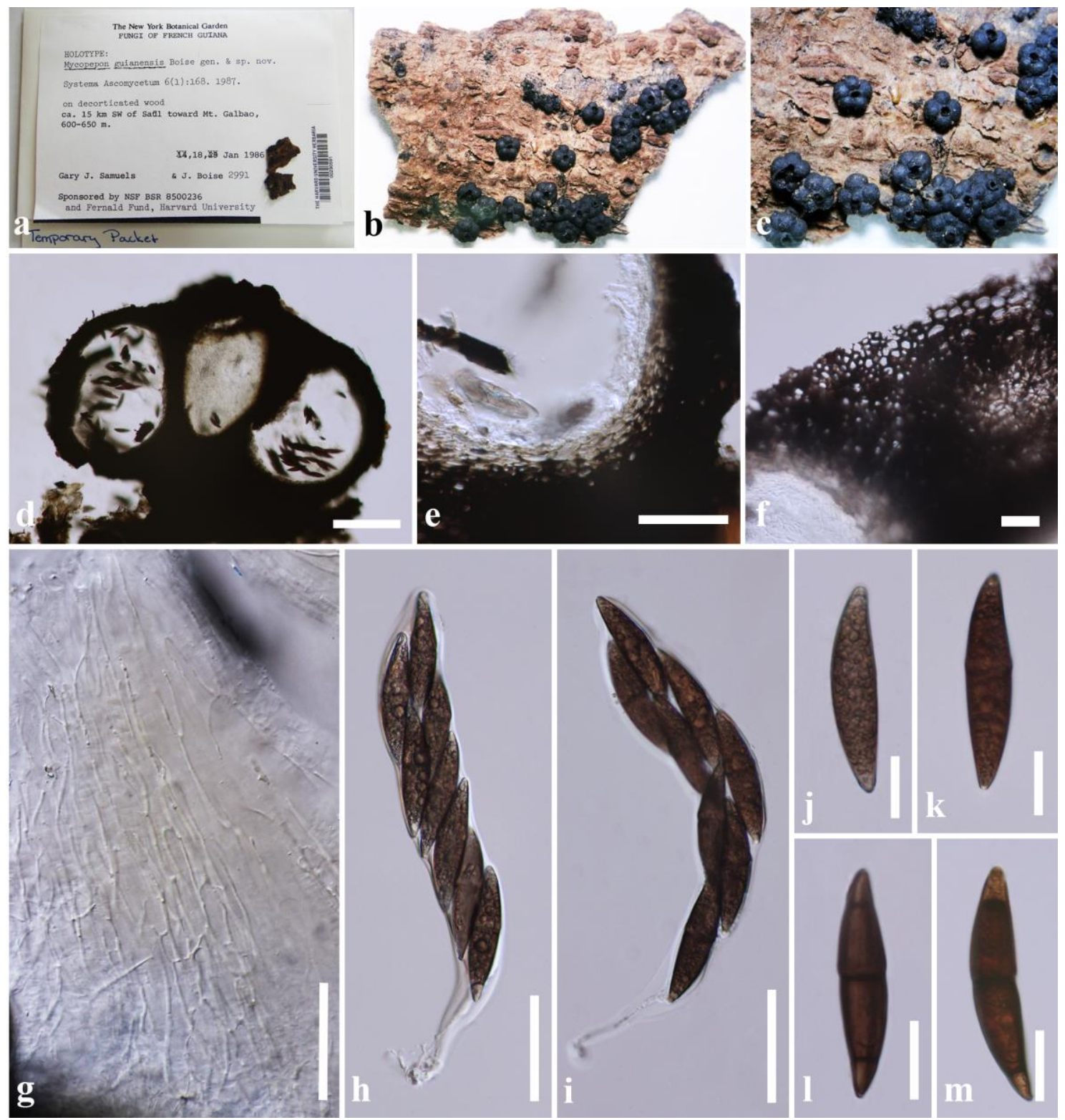

Figure 19 - Mycopepon guianensis (FH 00290591, holotype). a Herbarium label and specimen. $\mathrm{b}$, c Appearance of ascostromata on the host substrate. $\mathrm{d}$ Vertical section through ascostroma. e, f Peridium. g Trabeculate pseudoparaphyses. h, i Asci. j-m Ascospores. Scale bars: $d=200 \mu \mathrm{m}$, e, $\mathrm{g}-\mathrm{i}=50 \mu \mathrm{m}, \mathrm{f}, \mathrm{j}-\mathrm{m}=20 \mu \mathrm{m}$. 
The type specimen of Eopyrenula leucoplaca could not be located. However, Harris (1973) examined representative collections from various herbaria worldwide and provided a description and illustration of ascospores of E. leucoplaca when he introduced the genus Eopyrenula. In this study, we examined and illustrate a herbarium specimen from S (S-L16275). The species is a corticolous lichen on bark that was collected from Sweden. Based on a comparison of morphological characters provided by Harris (1973), the herbarium specimen is typical E. leucoplaca in having brown, paler at the end cells, ellipsoidal to fusiform, 5-6-septate ascospores. Hence, we designate this herbarium specimen as the reference specimen of E. leucoplaca. However, specimen S-L16275 has a slightly larger pseudothecia, asci and ascospores than the protologue.

Eopyrenula leucoplaca (Wallr.) R.C. Harris, Michigan Bot. 12(1): 19 (1973)

Fig. 20

三Verrucaria leucoplaca Wallr., Fl. crypt. Germ. (Norimbergae) 3: 299 (1831)

Index Fungorum number: IF341935; Facesoffungi number: FoF04633

Facultatively lichenized, inhabiting bark with a Trentepohlia photobiont (Harris 1973, Hyde et al. 2013). Sexual morph: Ascomata 200-300 $\mu \mathrm{m}$ high, 260-470 $\mu \mathrm{m}$ diam. [ca. $0.3 \mathrm{~mm}$ diam., Harris 1973], perithecioid, semi-immersed to superficial, visible as dark spot, solitary, scattered, globose to subglobose, dark brown to black, ostiole central, with pore-like opening. Peridium 30$55 \mu \mathrm{m}$ wide [60-90 $\mu \mathrm{m}$ wide, Harris 1973], thick-walled, comprising several layers of small, dark brown cells, arranged in a textura epidermoidea. Hamathecium 1-1.5 $\mu \mathrm{m}$ wide [ca. $1 \mu \mathrm{m}$ wide, Harris 1973], composed dense, anastomosed, slightly constricted at the septa, narrowly cellular pseudoparaphyses, embedded in a gelatinous matrix. Asci 109-170 × 13-21.5 $\mu \mathrm{m}(\bar{x}=140.6 \times 13.6$ $\mu \mathrm{m}, \mathrm{n}=20$ ) [90-100 $\times 10-12 \mu \mathrm{m}$, Harris 1973], 8-spored, bitunicate, cylindrical to cylindric-clavate, short-pedicellate, apically rounded, with well-developed ocular chamber. Ascospores 27-37 $\times 8-12$ $\mu \mathrm{m}(\bar{x}=33.7 \times 10.2 \mu \mathrm{m}, \mathrm{n}=30)$ [18-24 $\times 5-9 \mu \mathrm{m}$, Harris 1973], overlapping 1-2-seriate, brown to dark brown, paler at the end cells, ellipsoidal to fusiform, septate, constricted at the septa, mostly larger in the middle cells, smooth-walled, with minute guttules. Asexual morph: Undetermined.

Material examined - SWEDEN, Närke, Göhtlunda, Hamrarna, corticolous lichen on bark, 1864, O.G. Blomberg (L 16275, reference specimen designated here).

\section{Pyrenidium Nyl., Flora, Regensburg 48: 210 (1865)}

Lichenicolous, associated with various unrelated hosts. Sexual morph: Ascomata perithecioid, pseudothecia, immersed to semi-immersed on host thalli, visible as tiny and shiny black dot on the host surface, scattered, solitary or aggregated in gall-like malformations of the host thallus, dark brown to black, globose to subglobose, apapillate, ostiole central, with pore-like opening. Peridium thick-walled, composed of several layers of dark brown to reddish brown pseudoparenchymatous cells, arranged in textura angularis to textura prismatica. Hamathecium composed of dense, filiform, anastomosed, cellular pseudoparaphyses, embedded in a gelatinous matrix. Asci (2-)4-8spored, bitunicate, fissitunicate, cylindrical to cylindric-clavate, short-pedicellate, apically rounded with ocular chamber. Ascospores overlapping 1-2-seriate, pale brown in immature state, reddish brown to dark brown in mature state, paler at the end cells, oblong to ellipsoidal, or fusiform, rounded or obtuse at the apex, usually 3-septate, constricted at the septa, smooth-walled. Asexual morph: Reported as coelomycete, pycnidial, with hyaline, simple, short-oblong conidia (NavarroRosinés \& Roux 2007, Knudsen \& Kocourková 2010).

Type species - Pyrenidium actinellum Nyl.

Notes - The genus Pyrenidium was introduced by Nylander (1865), with P. actinellum as the type species. The generic type was found on Leptogium teretiusculum sensu lato in Kent, England by Admiral $\mathrm{T}$ Jones and is described as a subfruticose, cyanophilous lichen, with dark brown perithecioid ascomata, with a bluish green hue, 4-spored, subcylindrical asci and brown to dark brown, paler at the ends, ellipsoidal, 3-septate ascospores (Hawksworth 1983, Navarro-Rosinés \& Roux 2007, Knudsen \& Kocourková 2010). Species of Pyrenidium have a cosmopolitan distribution found on lichen thalli, occurring on various substrates such as bark, rocks, soil, 
bryophytes or living leaves (Hawksworth 1980, 1983, Matzer 1996, Navarro-Rosinés \& Roux 2007, Knudsen \& Kocourková 2010, Aptroot 2014). The history of Pyrenidium was discussed in Hawksworth (1983).
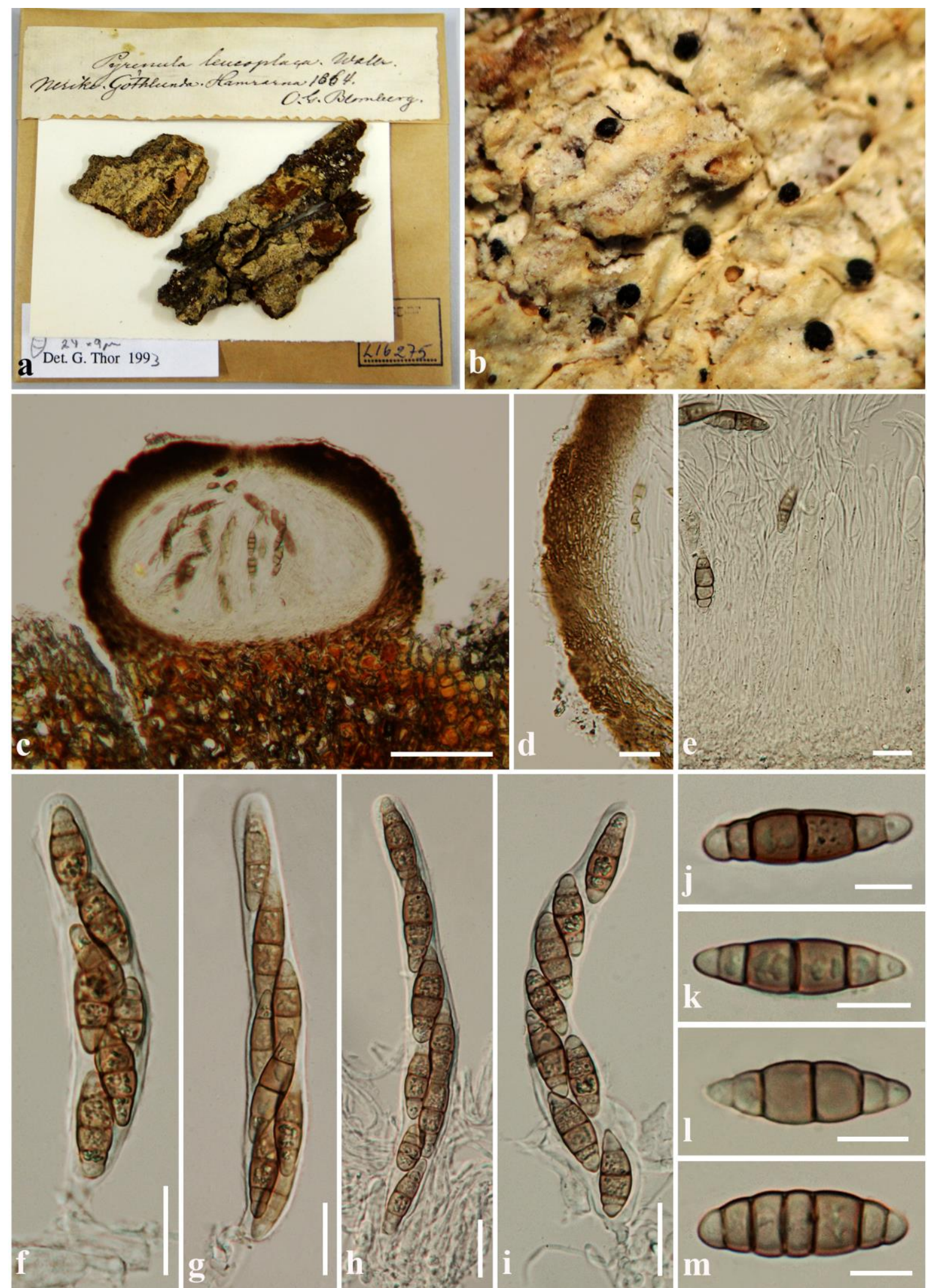

Figure 20 - Eopyrenula leucoplaca (L 16275, reference specimen). a Herbarium label and specimen. b Ascomata on host surface. c Vertical section through ascoma. d Peridium. e Pseudoparaphyses with ascospores. f-i Asci. j-m Ascospores. Scale bar: $c=100 \mu \mathrm{m}, \mathrm{d}-\mathrm{i}=20$ $\mu \mathrm{m}, \mathrm{j}-\mathrm{m}=10 \mu \mathrm{m}$. 
The genus includes eleven species (Index Fungorum 2018). Navarro-Rosinés \& Roux (2007) excluded Pyrenidium hyalosporum Alstrup, D. Hawksw. \& R. Sant. from Pyrenidium when they re-circumscribed this genus, as the species has hyaline ascospores. Based on morphological characters, Pyrenidium was accepted in the family Dacampiaceae (Lumbsch \& Huhndorf 2010, Hyde et al. 2013, Wijayawardene et al. 2014, 2018, Jaklitsch et al. 2016, Index Fungorum 2018). There are no sequence data available in GenBank (2018). Molecular data are needed to establish the accurate placement of this genus. Thus, the description and illustration of the lectotype specimen are provided herein. Pyrenidium is the type of the family Pyrenidiaceae Zahlbr., currently a synonym of Dacampiaceae, but molecular data are needed to verify if this synonymy is justified.

Pyrenidium actinellum Nyl., Flora, Regensburg 48: 210 (1865)

Fig. 21 Index Fungorum number: IF403001; Facesoffungi number: FoF04634

Lichenicolous on host thallus from various taxa. Sexual morph: Ascomata 130-188 $\mu \mathrm{m}$ high, 150-190 $\mu \mathrm{m}$ diam. [150-200 $\mu \mathrm{m}$ diam., Navarro-Rosinés \& Roux 2007], perithecioid, pseudothecia, immersed to semi-immersed on host thalli, visible as tiny and shiny black dot on the host surface, scattered, solitary or aggregated in gall-like malformations of the host thallus, dark brown to black, globose to subglobose, apapillate, ostiole central, with pore-like opening. Peridium 25-50 $\mu \mathrm{m}$ wide [30-40 $\mu \mathrm{m}$ wide, Navarro-Rosinés \& Roux 2007], thick-walled, composed of several layers of dark brown to reddish brown pseudoparenchymatous cells, arranged in textura angularis to textura prismatica, inner layers comprising hyaline cells. Hamathecium $1.5-2.5 \mu \mathrm{m}$ wide [1.5-2.5 $\mu \mathrm{m}$ wide, Navarro-Rosinés \& Roux 2007], composed of dense, filiform, anastomosed, cellular pseudoparaphyses, constricted at the septa, embedded in a gelatinous matrix. Asci $40-88 \times 11-18 \mu \mathrm{m}(\bar{x}=71.5 \times 13.5 \mu \mathrm{m}, \mathrm{n}=20)[60-90 \times 12-18 \mu \mathrm{m}$, Navarro-Rosinés \& Roux 2007], 4-spored, bitunicate, fissitunicate, subcylindrical, short-pedicellate, apically rounded with indistinct ocular chamber. Ascospores 19-27 $\times 7-9 \mu \mathrm{m}(\bar{x}=23.1 \times 8.3 \mu \mathrm{m}, \mathrm{n}=30)$ [20-25($30) \times 7-10 \mu \mathrm{m}$, Navarro-Rosinés \& Roux 2007], overlapping 1-2-seriate, pale brown in immature state, reddish brown to dark brown in mature state, paler at the end cells, oblong to ellipsoidal, or fusiform, rounded or obtuse at the apex, usually 3-septate, constricted at the septa, smooth-walled. Asexual morph: Undetermined.

Material examined - UNITED KINGDOM, England, Kent, Maidstone, Boxley Hill, on Leptogium teretiusculum (Collemataceae), 1865, T. Jones (H-NYL 41028, lectotype).

Pseudonitschkia Coppins \& S.Y. Kondr., Arch. Protistenk. 52(2): 232 (1995)

Lichenicolous, commensal on thallus of Parmotrema tinctorum. Sexual morph: Ascomata superficial, visible as black dots on host surface, globose to subglobose, cupulate when dry, dark brown to black, scattered, solitary, surface rough, cracked and rugulose, indistinct ostiolate. Peridium thick-walled, composed of several layers of dark brown to black, pseudoparenchymatous cells, with thickened cell walls, arranged in a textura angularis and textura epidermoidea. Hamathecium composed of dense, filamentous, branched, anastomosed, narrowly cellular pseudoparaphyses, constricted at the septa, embedded in a gelatinous matrix. Asci (4-)5-6-(8)spored, bitunicate, fissitunicate, broadly clavate to ampulliform with sessile to short-pedicellate, apically rounded with indistinct ocular chamber, thick-walled at the apex. Ascospores overlapping 2-3-seriate, fusiform, initially hyaline, becoming yellowish brown to olivaceous at maturity, mostly 1-septate, becoming 2(-3)-septate at maturity, the upper cell shorter and larger than the lower cell, not constricted at the septa, smooth-walled, with thin, distinctive mucilaginous sheath surrounding ascospores in immature state. Asexual morph: Undetermined.

Type species - Pseudonitschkia parmotrematis Coppins \& S.Y. Kondr.

Notes - Pseudonitschkia was introduced as a monotypic genus by Coppins \& Kondratyuk (1995) and is typified by $P$. parmotrematis. The genus was reported as a commensal lichenicolous fungus occurring mainly on Parmotrema tinctorum (Delise ex Nyl.) Hale in South America (Paraguay, Venezuela), South Africa, Malawi and Nepal (Coppins \& Kondratyuk 1995). 

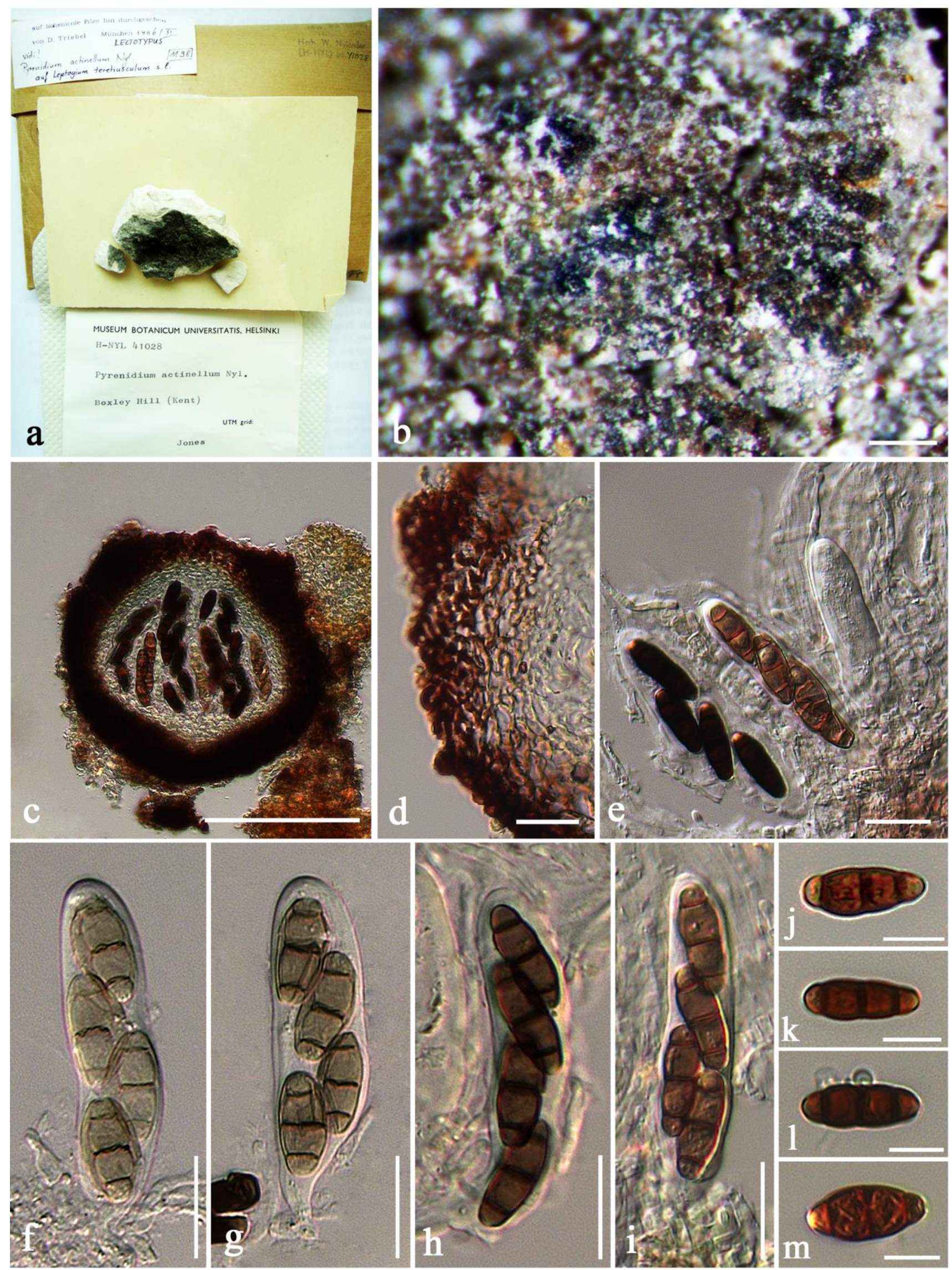

Figure 21 - Pyrenidium actinellum (H-NYL 41028, lectotype). a Herbarium label and specimen. b Ascomata on substrate. c Vertical section through ascoma. d Peridium. e Asci with pseudoparaphyses. $\mathrm{f}-\mathrm{i}$ Asci. $\mathrm{j}-\mathrm{m}$ Ascospores. Scale bars: $\mathrm{b}=1000 \mu \mathrm{m}, \mathrm{c}=100 \mu \mathrm{m}, \mathrm{d}-\mathrm{i}=20 \mu \mathrm{m}$, $\mathrm{j}-\mathrm{m}=10 \mu \mathrm{m}$. 
The genus was uniquely characterized by having rough-walled, blackish ascomata, with indistinct ostiolate, clavate to ampulliform asci and fusiform, hyaline to pale brown, 1-septate ascospores, with upper cell often wider than the lower cell (Coppins \& Kondratyuk 1995). Based on its distinctive morphological characters, Coppins \& Kondratyuk (1995) treated the genus in the Dothideales. Kirk et al. (2001) listed the genus in Dacampiaceae and this was accepted by subsequent authors (Hyde et al. 2013, Wijayawardene et al. 2014, 2017, 2018, Jaklitsch et al. 2016).

In this study, the type specimen of Pseudonitschkia parmotrematis was examined, described and illustrated. Pseudonitschkia is morphological distinct from other genera in Dacampiaceae in having colourless ascospores but resembles the genus Leptocucurthis (Aptroot \& van Iperen 1998). However, these two genera are different in many morphological aspects. There is no molecular data for P. parmotrematis in GenBank. Hence, we tentative place Pseudonitschkia in Dacampiaceae until the generic type is re-collected and molecular data is available to clarify its phylogenetic affinity.

Pseudonitschkia parmotrematis Coppins \& S.Y. Kondr., Edinb. J. Bot. 52(2): 232 (1995) Fig. 22 Index Fungorum number: IF413981; Facesoffungi number: FoF04635

Lichenicolous, commensal on thallus of Parmotrema tinctorum. Sexual morph: Ascomata 210-280 $\mu \mathrm{m}$ high, 220-270 $\mu \mathrm{m}$ diam. [(160-)200-340 $\mu \mathrm{m}$ diam., Coppins \& Kondratyuk 1995], superficial, visible as black dots on host surface, globose to subglobose, cupulate when dry, dark brown to black, scattered, solitary, surface rough, cracked and rugulose, indistinct ostiolate. Peridium 20-40 $\mu \mathrm{m}$ wide [19-34 $\mu \mathrm{m}$ wide, Coppins \& Kondratyuk 1995], composed of several layers of dark brown to black pseudoparenchymatous cells, with thickened walls, arranged in a textura angularis and textura epidermoidea. Hamathecium 1-2 $\mu \mathrm{m}$ wide [ca.0.7-1 $\mu \mathrm{m}$ wide, Coppins \& Kondratyuk 1995], composed of dense, filamentous, branched, anastomosed, narrowly cellular pseudoparaphyses, constricted at the septa, embedded in a gelatinous matrix. Asci 68-112 $\times$ 20-29.5 $\mu \mathrm{m}(\bar{x}=86.3 \times 23.6 \mu \mathrm{m}, \mathrm{n}=20)$ [95-100 $\times 21.5-29 \mu \mathrm{m}$, Coppins \& Kondratyuk 1995], 4-8-spored, bitunicate, fissitunicate, broadly clavate to ampulliform with sessile to shortpedicellate, apically rounded with indistinct ocular chamber, thick-walled at the apex. Ascospores $36-59 \times 7-9 \mu \mathrm{m}(\bar{x}=46.5 \times 7.8 \mu \mathrm{m}, \mathrm{n}=20)[(33.4-) 40-49(-63.3) \times 6.7-7.2(-8) \mu \mathrm{m}$, Coppins $\&$ Kondratyuk 1995], overlapping 2-3-seriate, fusiform, initially hyaline, becoming yellowish brown to olivaceous at maturity, mostly 1-septate, becoming 2(-3)-septate at maturity, the upper cell shorter and larger than the lower cell, not constricted at the septa, smooth-walled, with thin, distinctive mucilaginous sheath surrounding ascospores at immature state. Asexual morph: Undetermined.

Material examined -VENEZUELA, Guamitas, Parque Nacional, alt. $760 \mathrm{~m}$, on rock, on Parmotrema tinctorum, 29 December 1938, A.H.G. Alston 5836 (BM 000500107, holotype).

Didymellaceae Gruyter, Aveskamp \& Verkley, Mycol. Res. 113(4): 516 (2009)

The family Didymellaceae was introduced by De Gruyter et al. (2009) to accommodate Didymella exigua (Niessl) Sacc., together with some Phoma sections and related asexual morph genera that grouped together in the family. Several genera were added to the family based on morphological characteristics and phylogenetic relationships (De Gruyter et al. 2009, Aveskamp et al. 2010, Chen et al. 2015, Ariyawansa et al. 2015, Wijayawardene et al. 2016, Thambugala et al. 2017, Jayasiri et al. 2017). In this study we include Allophoma, Ascochyta, Boeremia, Briansuttonomyces, Calophoma, Didymella, Epicoccum, Heterophoma, Leptosphaerulina, Macroventuria, Monascostroma, Neoascochyta, Neodidymelliopsis, Neomicrosphaeropsis, Nothophoma, Paraboeremia, Phoma, Phomatodes, Stagonosporopsis, Xenodidymella in Didymellaceae following Hyde et al. (2013), Wijayawardene et al. (2017) and based on their morphology. The genus Didymellocamarosporium was discussed in Chen et al. (2017). Heracleicola was synonymized under Ascochyta (Chen et al. 2017). Several genera still need to be clarified with phylogenetic analysis (Chen et al. 2017). 


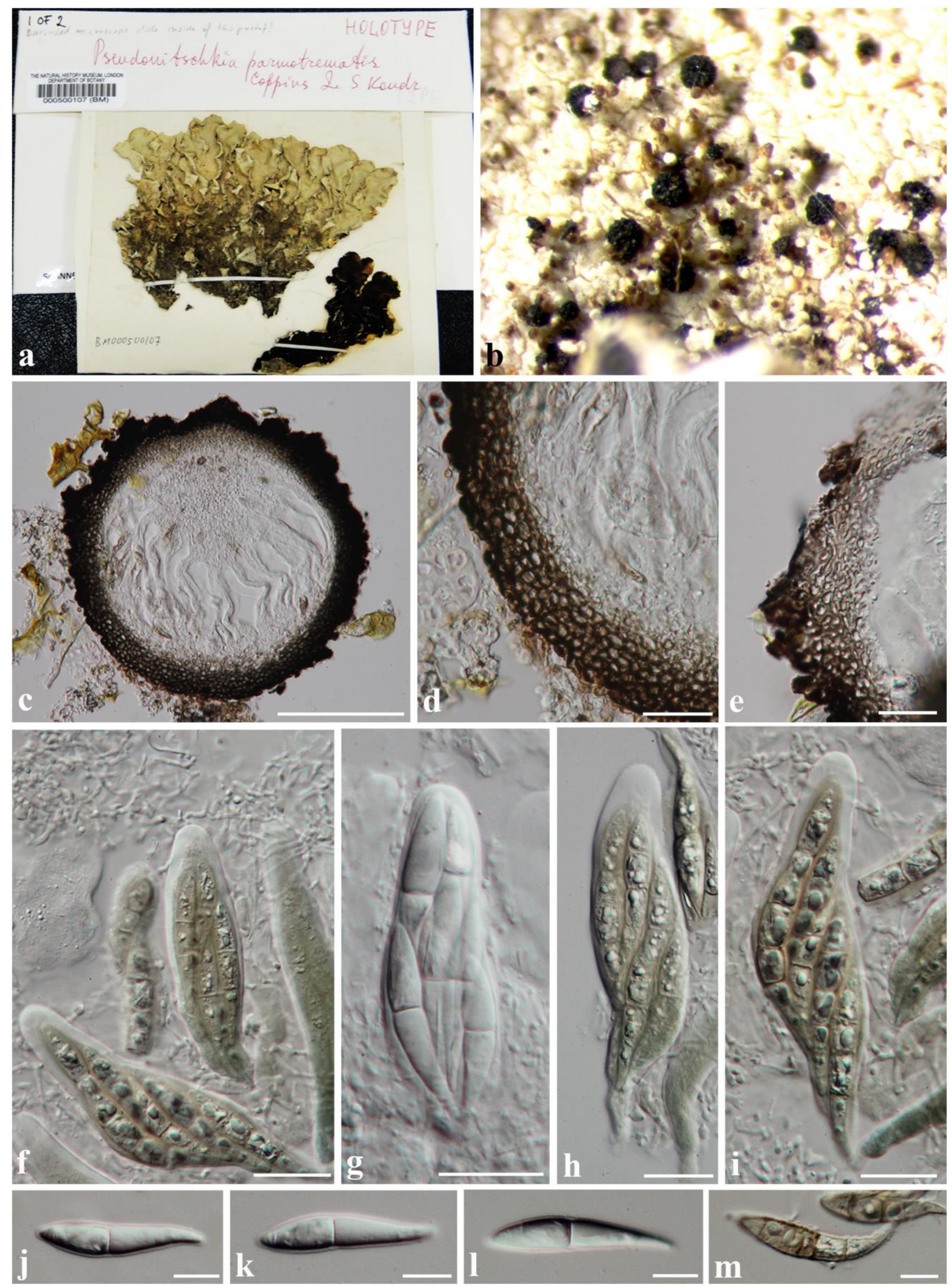

Figure 22 - Pseudonitschkia parmotrematis (BM 000500107, holotype). a Herbarium label and specimen. b Ascomata on host surface. c Vertical section through ascoma. d, e Peridium. f Asci with pseudoparaphyses. g Immature ascus. h, i Mature asci. j-1 Immature ascospores. m. Mature ascospores. Scale bars: $c=100 \mu \mathrm{m}, \mathrm{d}-\mathrm{i}=20 \mu \mathrm{m}, \mathrm{j}-\mathrm{m}=10 \mu \mathrm{m}$. 
Macroventuria Aa, Persoonia 6(3): 359 (1971)

Saprobic on dead leaves and decayed canvas. Sexual morph: perithecia, immersed to semiimmersed, dark to black, globose to subglobose, with pale brown setae on the top of ascomata, Ostiole cylindrical, central opening, with setae, pore-like, periphysate. Setae septate, pale brown to hyaline, superficial, simple, erect, straight to slightly flexuous, tapering towards rounded apex. Peridium composed several layers of pale brown to reddish brown cells of textura angularis, inner layers of wall with light-coloured cells. Hamathecium not observed. Asci 8-spored, bitunicate, clavate, short-pedicellate. Ascospores 2-3-seriate, hyaline, ovoid to ellipsoidal, 1-septate, asymmetrical, constricted at the septum, apical cell wider and shorter than the slightly tapering basal cell, smooth-walled. Asexual morph: Undetermined.

Type species - Macroventuria anomochaeta Aa

Notes - Macroventuria was introduced by Van der Aa (1971) with Macroventuria anomochaeta as the type species and with an additional species, Macroventuria wentii. Macroventuria resembles Venturia by its setose pycnidia, but differs in the restricted number of relatively large asci, the ascospore morphology being highly comparable to that of Didymella (Van der Aa 1971). The traditional placement of Macroventuria was in Venturiaceae, as ascospores are two-celled, nearly hyaline, somewhat large, differing from Leptosphaerulina (Van der Aa 1971). Subsequently, Macroventuria was accommodated in Pseudosphaeriaceae by Barr (1982) and then in Pleosporaceae by Eriksson \& Hawksworth (1986) and Kodsueb et al. (2006a). Aveskamp et al. (2010) circumscribed the boundaries of

Didymellaceae, and confirmed that two strains of Macroventuria anomochaeta (CBS 525.71; type and CBS 502.72; isolate in this study) were best placed in Didymellaceae using phylogenetic studies. We examined specimen (CBS H-14194) which is not the type but it appears to be collected by the same person who collected the type.

Macroventuria anomochaeta Aa, Persoonia 6(3): 362 (1971)

Fig. 23

Index Fungorum number: IF317111; Facesoffungi number: FoF04636

Saprobic on decayed canvas and Medicago sativa. Sexual morph: Ascomata 70-150 $\mu \mathrm{m}$ high $\times 75-130 \mu \mathrm{m}$ diam. $(\bar{x}=105 \times 108 \mu \mathrm{m}, \mathrm{n}=15)$, perithecia, immersed to semi-immersed, dark to black, subglobose, with pale brown setae on the top, ostiolate. Ostiole up to $50 \mu \mathrm{m}$ long, 30-40 $\mu \mathrm{m}$ wide, cylindrical, central opening, with setae, pore-like, periphysate. Setae up to $60 \mu \mathrm{m}$ long, 2-4 $\mu \mathrm{m}$ wide, septate, pale brown to hyaline, superficial, simple, erect, straight to slightly flexuous, tapering towards rounded apex. Peridium 30-50 $\mu \mathrm{m}$ thick at the sides, composed several layers of pale brown to reddish brown cells of textura angularis, inner 2-3 layers of wall with light-coloured cells. Hamathecium not observed. Asci 59-85 $\times 20-27 \mu \mathrm{m}(\bar{x}=73 \times 24 \mu \mathrm{m}, \mathrm{n}=20)$, 8-spored, bitunicate, clavate, short-pedicellate. Ascospores 21-26 $\times 7-11 \mu \mathrm{m}(\bar{x}=23 \times 9 \mu \mathrm{m}, \mathrm{n}=30)$, 2-3seriate, hyaline, ovoid to ellipsoidal, 1-septate, asymmetrical, constricted at the septum, apical cell wider and shorter than the slightly tapering basal cell, smooth-walled. Asexual morph: Undetermined.

Material examined - SOUTH AFRICA, on Medicago sativa L. (Leguminosae), 1 June 1972, H. Van der Aa (CBS H-14194).

Monascostroma Höhn., Annls mycol. 16(1/2): 160 (1918)

Saprobic on dead stem and bark. Sexual morph: Ascomata solitary to aggregated, scattered, black, immersed, globose or subglobose, papillate, apex with papilla and with a pore-like, central ostiole. Peridium thick, composed of cells of textura angularis, thin-walled. Hamathecium comprising septate, hypha-like pseudoparaphyses. Asci 8 -spored, bitunicate, fissitunicate, oblong to ellipsoidal, without pedicel, apically rounded with an indistinct ocular chamber. Ascospores irregular arranged in ascus or crowded, fusoid with narrowly rounded ends, 1-septate, initially hyaline, becoming pale brown at maturity, deeply constricted at the median septum, upper cell often broader than lower one, with numerous small guttules, surrounded with sheath, verruculose. Asexual morph: Undetermined. 
Type species - Monascostroma innumerosum (Desm.) Höhn.

Notes - Monascostroma was introduced by Höhnel (1918) for a single species $M$. innumerosum (= Hendersonia innumerosa Desm.). The genus was classified in Pleosporaceae (Eriksson \& Hawksworth 1998, Kodsueb et al. 2006a). Subsequently, it was accepted in Didymellaceae based on a putative strain of Monascostroma innumerosum (CBS 345.50), which formed a robust clade in family Didymellaceae (Zhang et al. 2009a, 2012, Schoch et al. 2009, Hyde et al. 2013, Knapp et al. 2015). Chen et al. (2017) revisited Didymellaceae and did not recognize Monascostroma in the family Didymellaceae. The placement of this genus still needs to be clarified with molecular data. In this study, we accept the genus Monascostroma in the Didymellaceae, based on smaller ascomata, lack of periphyses, a thin-walled peridium and 2-celled ascospores.
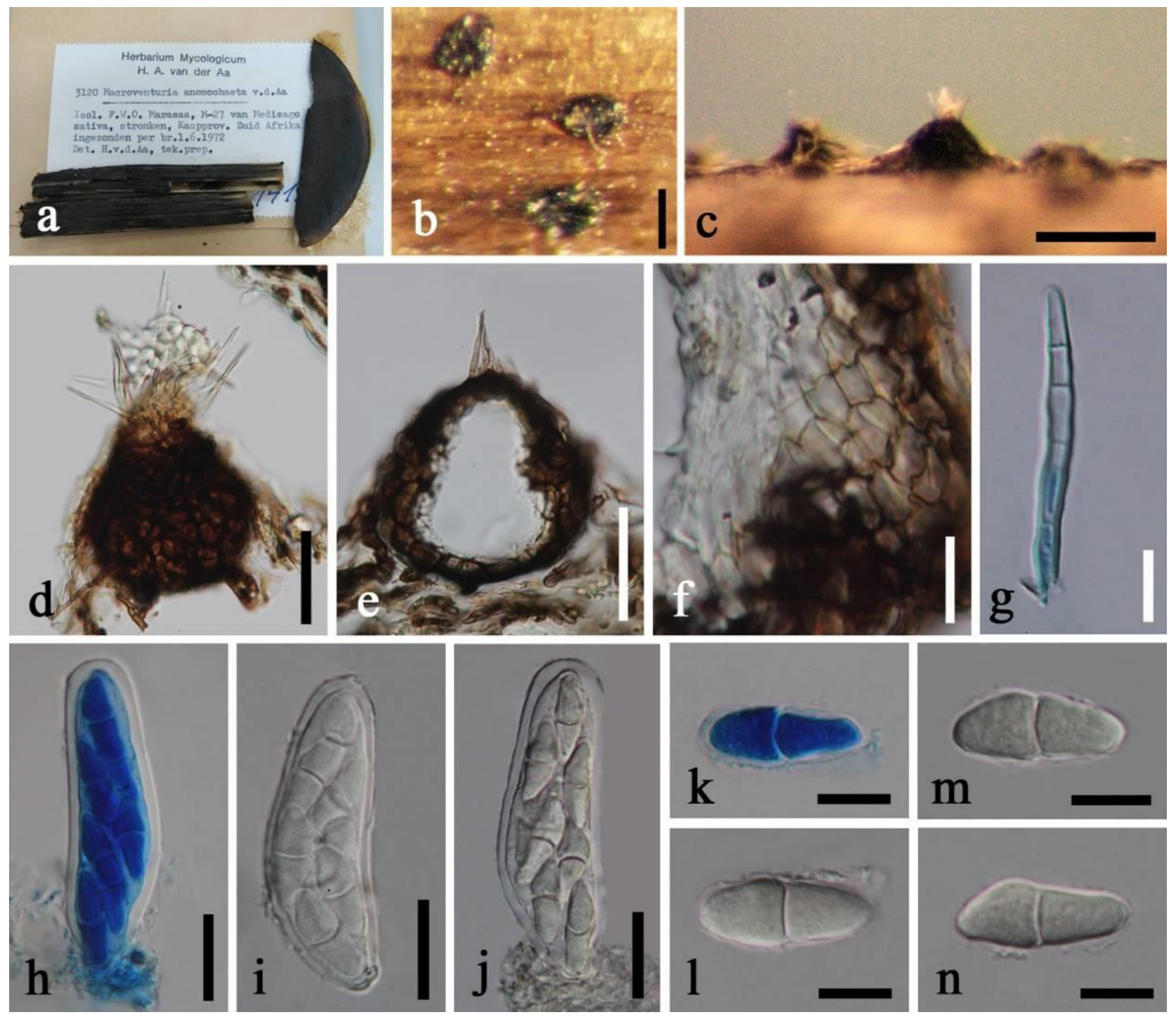

Figure 23 - Macroventuria anomochaeta (CBS H-14194). a Herbarium label and specimen. b Ascomata on host (top view). c Ascomata on host (side view). d Exterior ascoma with seta and oozing ascospores. e Section through ascoma with seta. f Peridium. g Setae. $h-i$ Asci. $\mathrm{k}-\mathrm{n}$ Ascospores. Note: $\mathrm{g}, \mathrm{h}, \mathrm{k}$ stained in lactophenol cotton blue. Scale bars: $\mathrm{b}=100 \mu \mathrm{m}, \mathrm{c}=200$ $\mu \mathrm{m}, \mathrm{d}, \mathrm{e}=50 \mu \mathrm{m}, \mathrm{f}, \mathrm{g}, \mathrm{k}-\mathrm{n}=10 \mu \mathrm{m}, \mathrm{h}-\mathrm{j}=20 \mu \mathrm{m}$.

Monascostroma innumerosum (Desm.) Höhn. [as 'innumerosa'], Annls mycol. 16(1/2): 160 (1918)

Fig. 24

三 Hendersonia innumerosa Desm., Annls Sci. Nat., Bot., sér. 3 16: 10 [repr.] (1851)

Index Fungorum number: IF144501; Facesoffungi number: FoF04637 
Saprobic on dead stem. Sexual morph: Ascomata 50-85 $\mu \mathrm{m}$ high $\times 60-105 \mu \mathrm{m}$ diam. $(\bar{x}=68$ $\times 90 \mu \mathrm{m}, \mathrm{n}=15$ ), solitary to aggregated, scattered, black, immersed, globose or subglobose, papillate, apex with papilla and with a pore-like, central ostiole. Peridium 13-20 $\mu \mathrm{m}$ thick, composed of cells of textura angularis cells, comprising two layers, outer layer; dark brown to reddish brown, thick-walled, inner layer comprising 3-5 cell layers, pale brown to hyaline, thinwalled. Hamathecium comprising 1.5-3 $\mu \mathrm{m}$ wide, septate, hypha-like pseudoparaphyses. Asci 40$70 \mu \mathrm{m} \times 23-34 \mu \mathrm{m}(\bar{x}=52 \times 28 \mu \mathrm{m}, \mathrm{n}=20), 8$-spored, bitunicate, fissitunicate, oblong to ellipsoidal, without pedicel, apically rounded with an indistinct ocular chamber. Ascospores 20-30 $\mu \mathrm{m} \times 7-11 \mu \mathrm{m}(\bar{x}=25 \times 9 \mu \mathrm{m}, \mathrm{n}=30)$, irregularly arranged in the ascus or crowded, fusoid with narrowly rounded ends, 1-septate, initially hyaline, becoming pale brown at maturity, deeply constricted at the median septum, upper cell often broader than lower one, with numerous small guttules, surrounded with gelatinous sheath, verruculose. Asexual morph: Undetermined.

Material examined - NETHERLANDS, Utrecht, Niederlande, Bilthoven, on Juncus conglomeratus (Juncaceae), 12 April 1950, J.A. von Arx (S-F234926).

\section{Didymosphaeriaceae Munk, Dansk bot. Ark. 15(no. 2): 128 (1953)}

Didymosphaeriaceae was introduced by Munk (1953) with Didymosphaeria as the generic type. They are characterized by brown, thick-walled, 1-septate ascospores, trabeculate pseudoparaphyses, which anastomose mostly above the asci in a gelatinous matrix (Aptroot 1995a, Hyde et al. 2013, Ariyawansa et al. 2014a, b, Wanasinghe et al. 2018). The species in this family are saprobes, endophytes and pathogens associated with numerous plant substrates (Hyde et al. 2013, Ariyawansa et al. 2014a, b, Liu et al. 2015, Tennakoon et al. 2016, Wanasinghe et al. 2016b). Ariyawansa et al. (2014b) revised the family and synonymized Montagnulaceae to Didymosphaeriaceae, which is the oldest name and has priority. Currently 26 genera are accepted in Didymosphaeriaceae (Wanasinghe et al. 2018, Wijayawardene et al. 2018).

Montagnula Berl., Icon. fung. (Abellini) 2: 68. 1896.

Saprobic on various flowering plants. Sexual morph: Ascostromata forming clypeus, visible and raised, solitary, large, black, longitudinal dome-shaped on the host surface. Ascomata immersed in the clypeus, uni- to bi-loculate, globose to subglobose, dark brown to black, clustered, ostiole central, with minute papillate. Peridium thick-walled, with unequal thickness, slightly thin at the base, thickest towards the apex, composed of several layers of dark brown to black, isodiametric, pseudoparenchymatous cells, integrated with host tissue, arranged in a textura angularis to textura prismatica. Hamathecium composed of dense, filamentous, broadly cellular pseudoparaphyses, indistinctly septate, anastomosing above the asci, embedded in a hyaline gelatinous matrix. Asci 8-spored, bitunicate, fissitunicate, cylindric-clavate, long-pedicellate, apically rounded with an ocular chamber. Ascospores overlapping, 1-2-seriate, hyaline to light brown when young, reddish brown to deep brown when mature, fusiform, 1-septate, constricted at the septum, mostly upper cell shorter and larger than lower cell, smooth-walled, with guttules, minutely echinulate. Asexual morph: Reported as hyphomycetes, irregularly branched conidiophores, bearing intercalary phialides, with simple, elongate conidia (Aptroot 1995b).

Type species - Montagnula infernalis (Niessl) Berl.

Notes -The genus Munkovalsaria was introduced by Aptroot (1995b) with two species Munkovalsaria rubra and $M$. donacina as the type species. Morphology of $M$. donacina differs from $M$. rubra by the simple ascocarp, black culture and no cresol production while $M$. rubra has a compound ascocarp, red culture, producing m-cresol (Aptroot 1995b). Aptroot (1995a, b) treated many species of Didymosphaeria as synonyms of Munkovalsaria. Later, M. appendiculata was introduced with 1-septate ascospores bearing long hyaline appendages (Aptroot 2004). Pitt et al. (2014) provided sequence data for $M$. donacina, which was collected from grapevines and desert ash in Australia. Munkovalsaria was subsequently treated as a synonym of Montagnula based on morphology and phylogenetic analysis of combined LSU, SSU and ITS sequence data of $M$. donacina HVVV01 and $M$. appendiculata CBS 109027 (type) which allied to the genus 
Montagnula (Wanasinghe et al. 2016b). Previously, three species of Munkovalsaria were introduced but recently these species have been synonymized (Index Fungorum 2018). Munkovalsaria donacina was listed under Montagnula donacina (Niessl) Wanas., E.B.G. Jones \& K.D. Hyde (Wanasinghe et al. 2016b). Munkovalsaria rubra was synonymized as Myrmaecium rubrum (Aptroot, Aa \& Petrini) Jaklitsch \& Voglmayr (2015). Munkovalsaria appendiculata was transferred to Montagnula appendiculata (Aptroot) Wanas., E.B.G. Jones \& K.D. Hyde (Wanasinghe et al. 2016b).

In this study, we examined the herbarium specimen from BPI, which was collected on Pseudosasa japonica from France and the specimen was determined by Aptroot (1995b) as Munkovalsaria donacina. Based on morphological identification, this specimen (BPI 749298) is typical Montagnula donacina. Hence, this specimen is verified herein as $M$. donacina following Wanasinghe et al. (2016b).
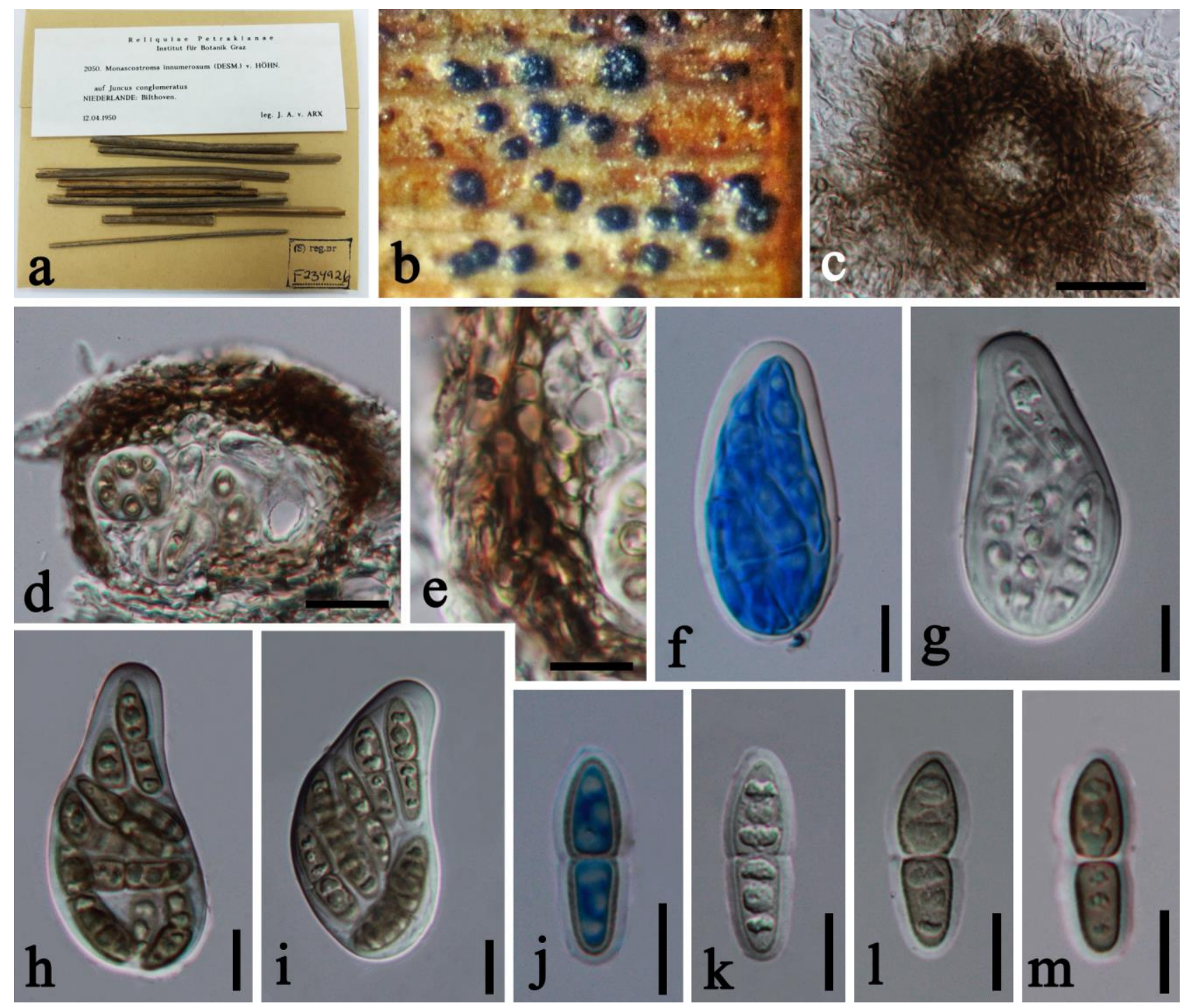

Figure 24 - Monascostroma innumerosum (S-F234926). a Herbarium label and specimen. b Ascomata on host (top view). c Squash mount of ascoma. d Vertical section through an ascoma. e Peridium. $\mathrm{f}-\mathrm{i}$ Asci. $\mathrm{j}-\mathrm{m}$ Ascospores. Note: $\mathrm{f}, \mathrm{j}$ stained in lactophenol cotton blue. Scale bars: $\mathrm{c}=$ $30 \mu \mathrm{m}, \mathrm{d}=20 \mu \mathrm{m}, \mathrm{e}-\mathrm{m}=10 \mu \mathrm{m}$.

Montagnula donacina (Niessl) Wanas., E.B.G. Jones \& K.D. Hyde, in Wanasinghe, Gareth Jones, Camporesi, Dissanayake, Kamolhan, Mortimer, Xu, Elsalam \& Hyde, Index Fungorum 319: 1 (2017)

Fig. 25

$\equiv$ Microthelia donacina Niessl, in Thümen, Inst. Coimbra 28: no. 536 (1879) 
EMunkovalsaria donacina (Niessl) Aptroot, Nova Hedwigia 60: 346 (1995)

$\equiv$ Didymosphaeria donacina (Niessl) Sacc., Syll. fung. (Abellini) 1: 715 (1882)

三Didymosphaerella donacina (Niessl) Cooke, Grevillea 18: 29 (1889)

Index Fungorum number: IF552762; Facesoffungi number: FoF04638

Saprobic on various flowering plants. Sexual morph: Ascostromata 1000-1800 $\mu \mathrm{m}$ diam., forming clypeus, visible and raised, solitary, large, black, longitudinal dome-shaped on the host surface. Ascomata 260-530 $\mu \mathrm{m}$ high, 400-570 $\mu \mathrm{m}$ diam., immersed in the clypeus, uni- to biloculate, globose to subglobose, dark brown to black, clustered, ostiole central, with minute papilla. Peridium 10-30 $\mu \mathrm{m}$ wide, thick-walled, with unequal thickness, slightly thinner at base, thicker towards apex, composed of several layers of dark brown to black, isodiametric, pseudoparenchymatous cells, integrated with host tissue, arranged in a textura angularis to textura prismatica. Hamathecium 1.5-2.5 $\mu \mathrm{m}$ wide, composed of dense, filamentous, broadly cellular pseudoparaphyses, indistinctly septate, anastomosing above the asci, embedded in a hyaline gelatinous matrix. Asci (87-)90-130(-150) $\times 11-12(-13)(-14)(-15) \mu \mathrm{m}(\bar{x}=112.3 \times 12.3 \mu \mathrm{m}, \mathrm{n}=$ 20), 8-spored, bitunicate, fissitunicate, cylindric-clavate, long-pedicellate, apically rounded with an ocular chamber. Ascospores 13-20 ×5-7.5 $\mu \mathrm{m}(\bar{x}=16.5 \times 6 \mu \mathrm{m}, \mathrm{n}=20)$, overlapping, 1-2seriate, hyaline to light brown when young, reddish brown to deep brown when mature, fusiform, 1-septate, constricted at the septum, upper cell usually shorter and larger than lower cell, smoothwalled, with guttules, minutely echinulate. Asexual morph: Reported as hyphomycetes, irregularly branched conidiophores, bearing intercalary phialides, with simple, elongate conidia (Aptroot 1995b).

Material examined - FRANCE, Lac de Leon 40180 Landes, on Pseudosasa japonica (Steud.) Makino (Poaceae), 6 February 1994, F. Candoussau 5396-1 (BPI 749298).

\section{Leptosphaeriaceae M.E. Barr, Mycotaxon 29: 503 (1987)}

The family Leptosphaeriaceae was established by Barr (1987a) and is typified by Leptosphaeria having conical or globose ascomata, narrow asci and coelomycetous asexual morphs in the order Pleosporales. Leptosphaeriaceae is similar to Phaeosphaeriaceae but differs by its peridium structure, hosts and asexual morphs (Câmara et al. 2002, Kirk et al. 2008, Zhang et al. 2012, Hyde et al. 2013, Phookamsak et al. 2014, Dayarathne et al. 2015). The family has a cosmopolitan distribution but is particularly prominent in temperate regions (Cannon \& Kirk 2007). Species in this family are endophytes, saprobes or grow as necrotrophs on the stems or leaves of various host plants and include economically important plant pathogens (Rouxel \& Balesdent 2005, De Gruyter et al. 2013, Hyde et al. 2013). Comprehensive descriptions and illustrations for members in Leptosphaeriaceae including a well-resolved backbone tree were provided in Ariyawansa et al. (2015). Additional new taxa in this family have been introduced by Ariyawansa et al. (2015), Dayarathne et al. (2015), Hyde et al. (2016), and Wanasinghe et al. (2016a).

Chaetoplea (Sacc.) Clem., in Clements \& Shear, Gen. fung., Edn 2 (Minneapolis): 275 (1931)

इPyrenophora subgen. Chaetoplea Sacc., Syll. fung. (Abellini) 2: 279 (1883)

Saprobic on dead leaves. Sexual morph: Chaetoplea dasylirii (see Ramaley 1995). Asexual morph: Parahendersonia dasylirii; Conidiomata solitary or scattered, black, convex to flattened on the top, immersed to erumpent through the outer layer of the host tissue to near superficial, conidiomata open via a slit, with a small papilla, narrow clypeus. Conidiomata walls comprising several layers with cells of textura angularis, the outer layers composed of brown to black, thickwalled cells, lighter towards the inner layers of hyaline cells, brown hyphae emerge from the wall into substrate. Conidiogenous cells proliferation enteroblastic, phialidic, cylindrical, terminal, with slight tapering towards apex. Macroconidia not observed. Microconidia fusoid to ellipsoidal, hyaline, smooth-walled, thin-walled, aseptate, rounded apex.

Type species - Chaetoplea calvescens (Fr. ex Desm.) Clem.

Notes - We examined the holotype specimen of Parahendersonia dasylirii, which was reported as the coelomycete asexual morph of Chaetoplea dasylirionis (Ramaley 1995). 
Parahendersonia was introduced by Ramaley (1995) with Parahendersonia dasylirii as the type species. The genus comprises two species epithets (Index Fungorum 2018). Ramaley (1995) accommodated $P$. dasylirii as the coelomycete asexual morph of Chaetoplea dasylirionis based on conidiomata and ascomata that were co-occurring on the host. Moreover, colonies in cultures from either conidia or asci had identical appearance and those from both sources produced Parahendersonia conidia. Parahendersonia was tentatively accommodated in Phaeosphaeriaceae (Barr 1987a, Hyde et al. 2011, 2013). Recently, the genus was placed in Leptosphaeriaceae (Wijayawardene et al. 2018).

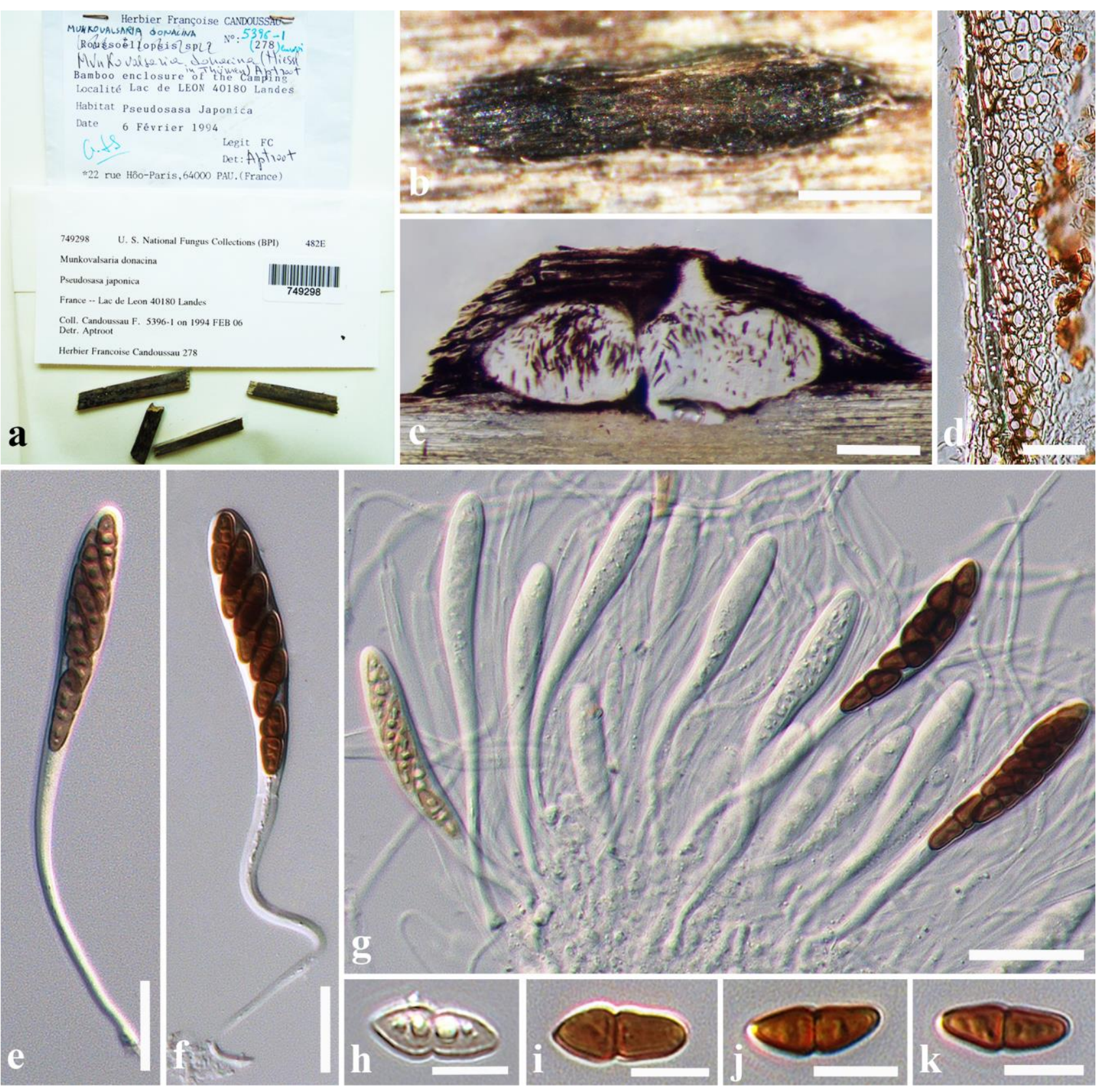

Figure 25 - Montagnula donacina (BPI 749298). a Herbarium label and specimen. b Ascostroma on the host surface. c Vertical section through ascostroma. d Peridium. e, f Asci. g Asci embedded in pseudoparaphyses. $\mathrm{h}$ Immature ascospore. $\mathrm{i}-\mathrm{k}$ Ascospores. Scale bar: $\mathrm{b}=500 \mu \mathrm{m}$, $\mathrm{c}=200 \mu \mathrm{m}, \mathrm{d}-\mathrm{g}=20 \mu \mathrm{m}, \mathrm{h}-\mathrm{k}=10 \mu \mathrm{m}$.

Chaetoplea dasylirii A.W. Ramaley [as 'dasylirionis'], Aliso 14(2): 151 (1995)

Fig. 26

Index Fungorum number: IF414790; Facesoffungi number: FoF04639 
Saprobic on dead leaves. Sexual morph: Chaetoplea dasylirii (see Ramaley 1995). Asexual morph: Parahendersonia dasylirii; Conidiomata 320-360 $\mu \mathrm{m}$ high $\times 350-400 \mu \mathrm{m}$ diam., solitary or scattered, black, convex to flattened on the top, immersed to erumpent through the outer layer of the host tissue to near superficial, conidiomata open via a slit, with a small papilla, narrow clypeus. Conidiomata walls comprising several layers with cells of textura angularis, the outer layers composed of brown to black, thick-walled cells, lighter towards the inner layers of hyaline cells, brown hyphae emerge from the wall into substrate. Conidiogenous cells proliferation enteroblastic, phialidic, cylindrical, terminal, with slight tapering towards apex. Macroconidia not observed. Microconidia 4-8 $\times 2-3 \mu \mathrm{m}(\bar{x}=6 \times 2.5, \mathrm{n}=30)$, fusoid to ellipsoidal, hyaline, smooth-walled, thin-walled, aseptate, rounded apex.

Material examined - USA, Texas, Big Ben National Park, Brewster Co., on dead leaves of Dasylirion leiophyllum Engelm. ex Trel. (Asparagaceae), 9 May 1994, A. Ramaley (BPI 802795, holotype of Parahendersonia dasylirii).

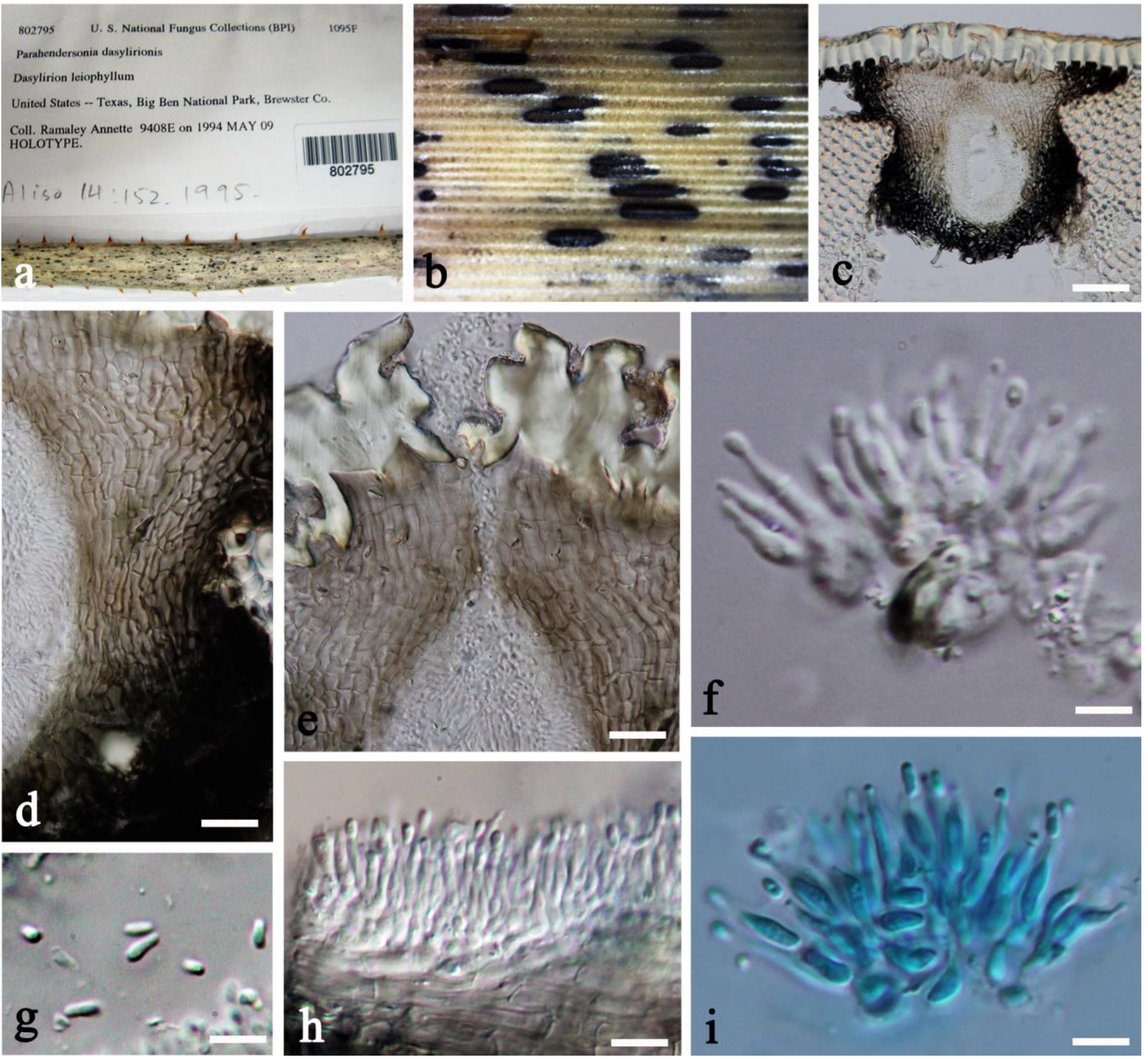

Figure 26 - Chaetoplea dasylirii (BPI 802795, holotype of Parahendersonia dasylirii). a Herbarium material. b Conidiomata on host substrate. c Vertical section of conidioma. d Conidiomata wall. e Close up of ostiole. $\mathrm{f}, \mathrm{h}$, i Conidiogenous cells with conidia. g Conidia. Scale bars: $\mathrm{c}=100 \mu \mathrm{m}, \mathrm{d}, \mathrm{e}=50 \mu \mathrm{m}, \mathrm{f}, \mathrm{h}, \mathrm{i}=10 \mu \mathrm{m}, \mathrm{g}=5 \mu \mathrm{m}$. 
Lindgomycetaceae K. Hiray., Kaz. Tanaka \& Shearer, in Hirayama, Tanaka, Raja, Miller \& Shearer, Mycologia 102(3): 733 (2010)

Lindgomycetaceae is a freshwater ascomycete family that belongs in Pleosporales, Dothideomycetes. Species have been isolated from decaying or decorticated stems or twigs of submerged woody plants in freshwater habitats, such as lakes, ponds, rivers, and irrigation canals, and associated with IgG4-related sclerosing disease of a human foot (Hyde 1993, Shearer et al. 2009, Abdel-Aziz \& Abdel-Wahab 2010, Hirayama et al. 2010, Raja et al. 2011, 2013, Tsang et al. 2014). The family is characterized by subglobose to globose ascomata, fissitunicate, cylindrical to clavate asci, fusiform to cylindrical, uni- to multiseptate, hyaline to brown ascospores, usually covered with an entire sheath and/or bipolar mucilaginous appendages (Hirayama et al. 2010). Lindgomyces was proposed as type genus on the basis of morphological and molecular data (Hirayama et al. 2010). The family currently includes five genera, Arundellina Wanas. et al., Clohesyomyces K.D. Hyde, Hongkongmyces Tsang et al., Lindgomyces K. Hiray. et al., and Lolia Abdel-Aziz \& Abdel-Wahab (Wijayawardene et al. 2018).

Lindgomyces K. Hiray., Kaz. Tanaka \& Shearer, in Hirayama, Tanaka, Raja, Miller \& Shearer, Mycologia 102(3): 733 (2010)

Saprobic on submerged, decorticated woody debris. Sexual morph: Ascomata solitary, scattered, immersed to erumpent, black, subglobose, thick-walled, ostiolate, papillate. Beak conspicuous, central, with periphyses. Peridium outer layer composed of thick-walled, dark brown to brown, small cells, forming clypeus-like structure, inner layer composed of thin-walled, hyaline, large cells of textura angularis. Asci 8-spored, bitunicate, fissitunicate, cylindrical to clavate, slightly curved or straight, rounded at the apex, short-pedicellate, smooth, thick-walled, with an ocular chamber. Ascospores fusiform, hyaline becoming brown, pointed at both ends, straight to slightly curved, septate, not constricted at the septa, smooth-walled, guttulate, with a thick gelatinous sheath. Asexual morph: Undetermined.

Type species - Lindgomyces ingoldianus (Shearer \& K.D. Hyde) K. Hiray., Kaz. Tanaka \& Shearer

Notes - Lindgomyces ingoldianus is the type species of genus Lindgomyces (Shearer et al. 2009) Shearer \& Hyde (1997) originally described this species based on a submerged specimen, and placed it in Massarina, but Shearer et al. (2009) placed the species in Lindgomycetaceae Hirayama et al. (2010) formally introduced a new family Lindgomycetaceae and new genus Lindgomyces based on the morphological data and phylogenetic analysis. Lindgomyces ingoldianus is morphologically similar to L. rotundatus but differs from the latter by the large ascospores with pointed ends (Hirayama et al. 2010).

Lindgomyces ingoldianus (Shearer \& K.D. Hyde) K. Hirayama, Kaz. Tanaka \& Shearer Fig. 27

三 Massarina ingoldiana Shearer \& K.D. Hyde, Mycologia 89(1): 114 (1997)

Index Fungorum number: IF515189; Facesoffungi number: FoF04640

Saprobic on submerged, decorticated woody debris. Sexual morph: Ascomata 200-300 $\mu \mathrm{m}$ high, 200-450 $\mu \mathrm{m}$ diam., solitary, scattered, immersed to erumpent, black, subglobose, thickwalled, ostiolate, papillate. Beak conspicuous, central, 60-80 $\mu \mathrm{m}$ long, 90-120 $\mu \mathrm{m}$ wide, with periphyses. Peridium 20-45 $\mu \mathrm{m}$ wide, outer layer composed of thick-walled, dark brown to brown, small cells, forming clypeus-like structure, inner layer composed of thin-walled, hyaline, large cells of textura angularis, $10-15 \times 3-5 \mu \mathrm{m}$. Asci $100-200 \times 20-35 \mu \mathrm{m}(\bar{x}=190 \times 28.6, \mathrm{n}=20)$, 8spored, bitunicate, fissitunicate, cylindrical to clavate, slightly curved or straight, rounded at the apex, short-pedicellate, smooth, thick-walled, with an ocular chamber. Ascospores 40-65 × 9-15 $\mu \mathrm{m}(\bar{x}=54.6 \times 10.4, \mathrm{n}=20), 2-4$-seriate, fusiform, hyaline becoming brown, pointed at both ends, straight to slightly curved, 1-3-septate, not constricted at the septa, smooth-walled, guttulate, with a thick gelatinous sheath. Asexual morph: Undetermined. 
Material examined - USA, Wisconsin, Adams County, Lemonweir River, on submerged, decorticated woody debris, 31 July 1992, C.A. Shearer \& J.L. Crane A-39-1 (ILLS 52289, holotype).

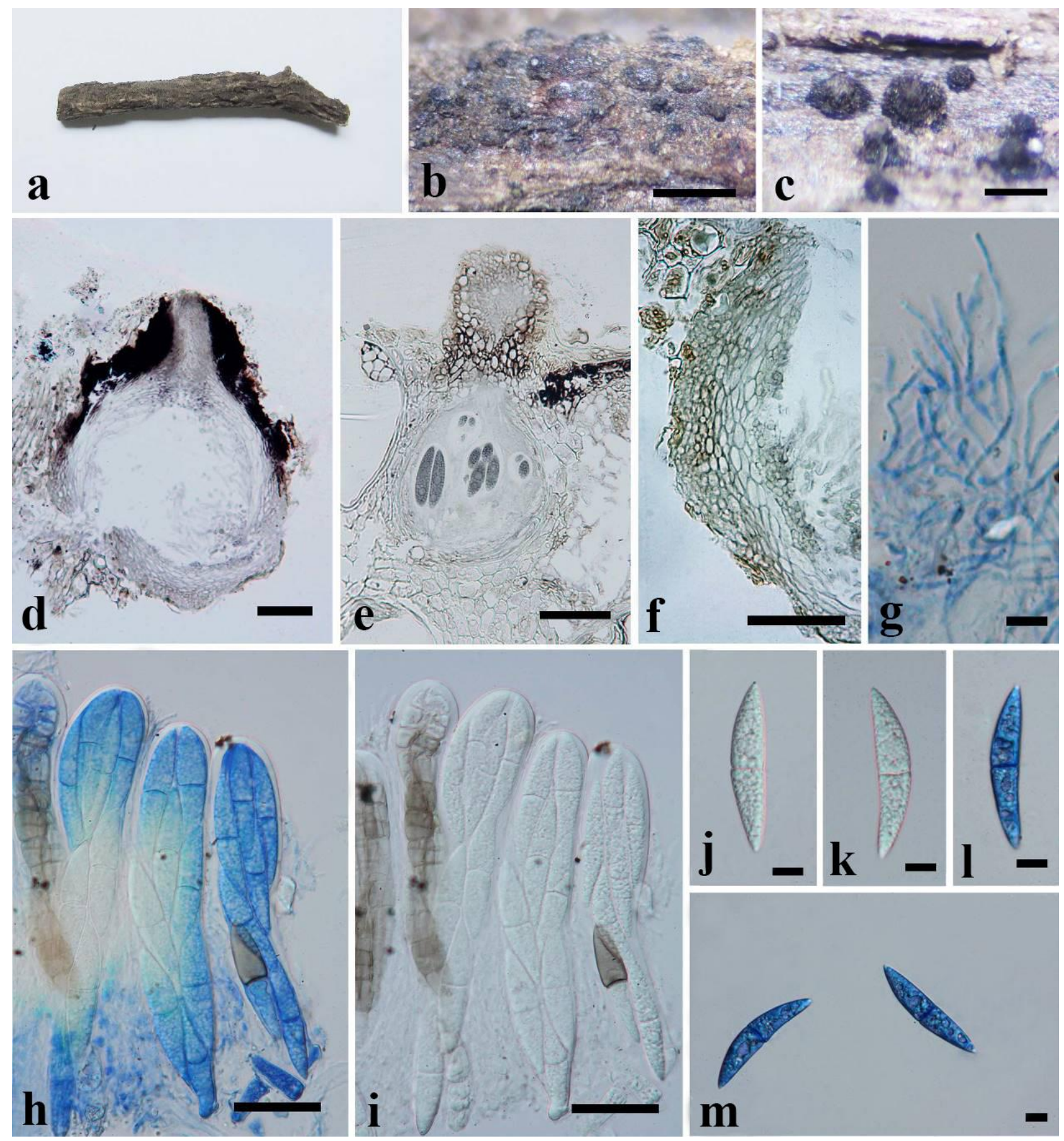

Figure 27 - Lindgomyces ingoldianus (ILLS 52289, holotype). a Herbarium specimen. b, c Appearance of black ascomata on host surface. d, e Vertical sections of ascomata. f Peridium. g Pseudoparaphyses. h, i Asci. j-m Ascospores. Note: g, h, l, m stained in lactophenol cotton blue. Scale bars: $b=1 \mathrm{~mm}, \mathrm{c}=500 \mu \mathrm{m}, \mathrm{d}, \mathrm{e}=100 \mu \mathrm{m}, \mathrm{f}, \mathrm{g}=50 \mu \mathrm{m}, \mathrm{h}, \mathrm{i}=30 \mu \mathrm{m}, \mathrm{j}-\mathrm{m}=10 \mu \mathrm{m}$.

Lophiostomataceae Sacc. [as 'Lophiostomaceae'], Syll. fung. (Abellini) 2: 672 (1883)

The family Lophiostomataceae is characterized by immersed to erumpent, carbonaceous to coriaceous ascomata, with rounded or slit-like ostiolar opening on a laterally compressed papilla, crest-like apex, cylindrical to clavate asci and hyaline to dark brown, 1-multi-septate, or muriform 
ascospores (Hyde et al. 2013, Thambugala et al. 2015). The species of Lophiostomataceae are saprobic on twigs or bark of numerous woody and herbaceous plants in terrestrial and aquatic environments (Hyde et al. 2002, Tanaka \& Harada 2003, Crous et al. 2013, Ariyawansa et al. 2015, Lui et al. 2015, Tibpromma et al. 2017). The family was revised by Thambugala et al. (2015) with a backbone tree to the family. Eighteen genera were accepted by Wijayawardene et al. (2018). In this study we transfer Thyridium concinnum (Thyridiaceae, Sordariomycetes) to Platystomum concinnum (Lophiostomataceae, Dothideomycetes) based on morphology.

Platystomum Trevis., Bull. Soc. R. Bot. Belg. 16: 16 (1877)

Type species - Platystomum compressum (Pers.) Trevis.

Saprobic on dead stem. Sexual morph: Ascomata black, solitary, gregarious or confluent, immersed to semi-immersed, globose to ellipsoidal or pyriform, unilocular, glabrous, papillate, ostiolate. Ostiole well-developed long neck, usually with widely porate, crest-like papilla, gradually narrowed upward, obtuse apex, brown to black, thick-walled. Peridium composed of brown to hyaline, thick-walled cells of textura angularis. Hamathecium comprising cellular, septate, unbranched, interlaced pseudoparaphyses. Asci bitunicate, fissitunicate, cylindrical to clavate, rounded above, narrow below, pedicellate, straight or slightly curved, with an ocular chamber. Ascospores light yellow when young, brown to dark olive when mature, fusiform to oblong, elongated ellipsoidal, oblong ovate, muriform, constricted at all septa, smooth-walled, rounded at both ends, thick-walled. Asexual morph: undetermined.

Notes - Platystomum was introduced by Trevisan (1877) to accommodate six species; $P$. angustatum, $P$. compressum (the generic type), $P$. fraudulentum, $P$. gregarium, $P$. hygrophilum and $P$. ramorum. The genus is characterized by coriaceous to carbonaceous, dark brown to black ascomata, slit or slot-like ostiole, with or without a crest, cellular pseudoparaphyses, fissitunicate, cylindric-clavate asci, with an ocular chamber, ellipsoidal to fusiform, muriform ascospores (Hyde et al. 2013, Thambugala et al. 2015). Platystomum morphologically resembles Lophiostoma but it has muriform ascospores, while Lophiostoma has phragmospores (Tanaka \& Harada 2003). Several studies have discussed their relationship (Holm \& Holm 1988, Barr 1990, Mugambi \& Huhndorf 2009, Hyde et al. 2013, Thambugala et al. 2015). In this study we observed the isotype specimen (GZU 000301526) of Thyridium concinnum. Its morphology is most similar to Platystomum, differing from Thyridium by ascomata with a crest-like ostiole and fissitunicate asci with an ocular chamber features lacking in Thyridium. Thus, we provide a new combination for Platystomum concinnum based on morphological comparison.

Platystomum concinnum (Petr.), Doilom \& K.D. Hyde, comb. nov.

Fig. 28

三Thyridium concinnum Petr., Sydowia 3(1-6): 303 (1949)

Index Fungorum number: IF554796; Facesoffungi number: FoF04641

Saprobic on dead stem of Polygonum sp. (Polygonaceae). Sexual morph: Ascomata $222 \times$ $500 \mu \mathrm{m}$ diam., 306-706 $\mu \mathrm{m}$ high, black, solitary, gregarious or confluent, immersed to semiimmersed, globose to ellipsoidal or pyriform, unilocular, glabrous, papillate, ostiolate. Ostiole 139$145 \mu \mathrm{m}$ long, 60-139 $\mu \mathrm{m}$ wide, with well-developed long neck, usually with widely porate, crestlike papilla, gradually narrowed upward, obtuse apex, brown to black, thick-walled. Peridium 15$28 \mu \mathrm{m}$ wide, composed of brown to hyaline, thick-walled cells of textura angularis. Hamathecium comprising 1-3 $\mu \mathrm{m}$ wide, cellular, dense, septate, unbranched, interlaced pseudoparaphyses. Asci 88-182 × 11-18 $\mu \mathrm{m}(\bar{x}=129 \times 14, \mathrm{n}=20), 2-8$-spored, bitunicate, fissitunicate, cylindrical to clavate, rounded above, narrow below, mostly long-pedicellate, straight or slightly curved, with an ocular chamber. Ascospores 16.7-39 $\times 5.8-12.6 \mu \mathrm{m}(\bar{x}=23.6 \times 8.6, \mathrm{n}=20)$, uniseriate or overlapping seriate, light yellow when young, brown to dark olive when mature, fusiform to oblong, elongated ellipsoidal, oblong ovate, 7-10 transverse and several longitudinal to oblique septa, constricted at all septa, smooth, rounded at both ends, thick-walled. Asexual morph: undetermined. 
Material examined - IRAN, Shahrud-Bustan, mons Shahvar, Nokarman, 36 '32 'N/ $54^{\circ} 22^{\prime}$ E, 3300 m, on dead stem of Polygonum sp. (Polygonaceae), 23-24 July 1948, K.H. Rechinger (GZU 000301526, isotype of Thyridium concinnum).

Roussoellaceae Jian K. Liu, Phook., D.Q. Dai \& K.D. Hyde, in Liu et al., Phytotaxa 181(1): 7 (2014)

The family Roussoellaceae was introduced by Liu et al. (2014) and is typified by Roussoella Sacc. with $R$. nitidula Sacc. \& Paol. as the type species (Wijayawardene et al. 2017a). The family is characterized by semi-immersed to immersed, solitary or gregarious, clypeate ascostromata, long cylindrical to clavate bitunicate asci with or without obvious fissitunicate dehiscence, and brown, 2celled ornamented ascospores (Liu et al. 2014). The asexual morphs of Roussoellaceae are linked to Cytoplea, Melanconiopsis and Neomelanconium (Liu et al. 2014). Seven genera are accommodated in this family (Wijayawardene et al. 2018). Roussoellaceae was treated as a synonym of Thyridariaceae (Jaklitsch \& Voglmayr 2016). However, Tibpromma et al. (2017) accepted Roussoellaceae as a well resolved family in Pleosporales and this is followed in Liu et al. (2017) and Wijayawardene et al. (2018).

Immotthia M.E. Barr, Mycotaxon 29: 504 (1987)

Hyperparasitic on stromata of Hypoxylon sp. on Fraxinus, Salix, Acer, other hardwoods, and on apothecia of Pestalopezia rhododendri on leaves of Rhododendron maximum. Sexual morph: Ascostromata effuse, dark, numerous, superficial ascomata. Ascomata black, densely aggregated in large groups or loosely scattered, superficial subglobose to obpyriform, or inequilateral, uniloculate, glabrous, slightly rough, ostiole, central, with pore-like opening. Peridium comprising hyaline to pale brown cells, arranged in a textura prismatica to textura angularis. Hamathecium comprising trabeculate cellular pseudoparaphyses, distinctly septate, embedded in a hyaline gelatinous matrix. Asci 8-spored, bitunicate, fissitunicate, cylindrical, short-pedicellate, furcate pedicel, apically rounded. Ascospores overlapping 1-seriate, ellipsoidal to fusiform, brown to reddish brown, 1-septate, slightly constricted at the septum, round ends, rough-walled, echinulate. Asexual morph: coelomycetous asexual morphs with 1- or 2-celled conidia, like Chaetophoma, Coniothyrium and Pyrenochaeta (Jaklitsch et al. 2002, Akulov \& Hayova 2016, Hyde et al. 2017).

Type species - Immotthia hypoxylon (Ellis \& Everh.) M.E. Barr

Notes - Barr (1987c) assigned the genus Immotthia, which is typified by Immotthia hypoxylon (Ellis \& Everh.) M.E. Barr (三 Amphisphaeria hypoxylon Ellis \& Everh.), to Dacampiaceae (Dacampieae). Species are characterized by obpyriform to globose ascomata, usually gregarious on hypostroma, trabeculate pseudoparaphyses (sensu Liew et al. 2000), bitunicate asci, and fusoid, pigmented, 1-septate ascospores. Jaklitsch et al. (2002) synonymized $I$. hypoxylon under I. atrograna based on priority. Hyde et al. (2017) examined the type species of Immotthia hypoxylon (type of Amphisphaeria hypoxylon) and tentatively placed it in Roussoellaceae, based on the similar morphology of Immotthia and Roussoella. Both genera have brown, fusiform to ellipsoidal, 2-celled ascospores, cylindrical asci and a coelomycetous asexual morph with brown conidia, although Immotthia differs as its ascomata are borne on a basal ascostromata.

Barr (2002) published a new combination, Immotthia atroseptata (Piroz.) M.E. Barr, based on the description and illustration of Didymosphaeria atroseptata by Pirozynski (1973), and placed it in the Teichosporaceae. We re-examined the holotype specimen of Immotthia atroseptata (三 Didymosphaeria atroseptata) and place it in Roussoellaceae following Hyde et al. (2017). Type specimens of Immotthia species including fresh collections have been examined and placed in various families viz. Dacampiaceae, Teichosporaceae and Roussoellaceae (Jaklitsch et al. 2002, Zhang et al. 2012, Akulov \& Hayova 2016, Hyde at al. 2017). Molecular data is needed to clarify the natural placement of Immotthia. 

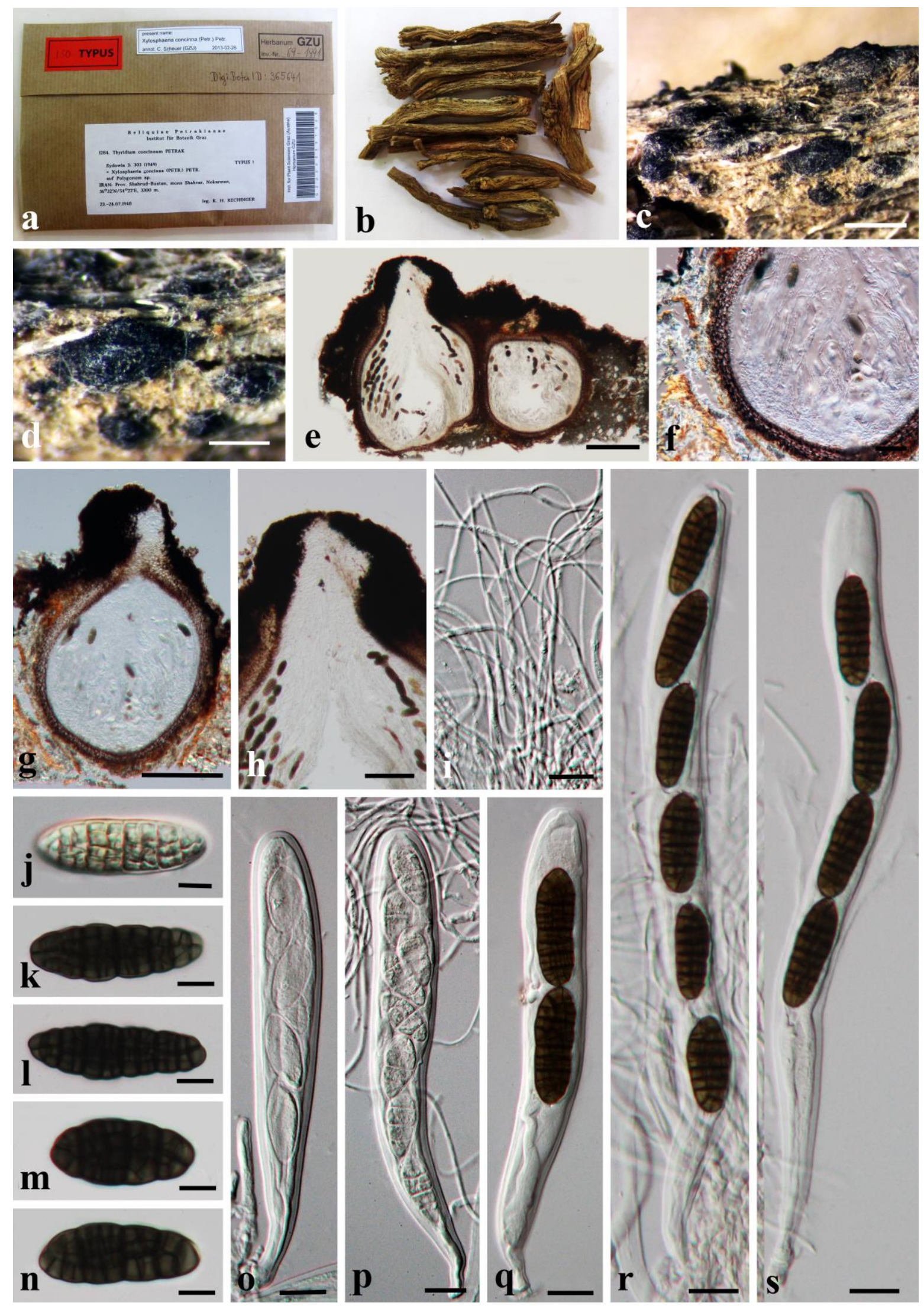

Figure 28 - Platystomum concinnum (GZU 000301526, isotype of Thyridium concinnum). a Herbarium label. b Herbarium specimen. c, d Appearance of black ascomata on the host. $\mathrm{e}, \mathrm{g}$ Vertical sections of ascomata with asci inside. $\mathrm{f}$ Peridium. h Ostiole. i Psedoparaphyses. $\mathrm{j}-\mathrm{n}$ Ascospores. o-s Asci. Scale bars: $\mathrm{c}=1000 \mu \mathrm{m}, \mathrm{d}=500 \mu \mathrm{m}, \mathrm{e}, \mathrm{g}=100 \mu \mathrm{m}, \mathrm{f}=20 \mu \mathrm{m}, \mathrm{h}=50$ $\mu \mathrm{m}, \mathrm{i}, \mathrm{o}-\mathrm{s}=10 \mu \mathrm{m}, \mathrm{j}-\mathrm{n}=5 \mu \mathrm{m}$. 
Hyperparasitic on apothecia of Pestalopezia rhododendri on fallen leaves of Rhododendron maximum. Sexual morph: Ascomata 190-350 $\mu \mathrm{m}$ high $\times 170-250 \mu \mathrm{m}$ diam. $(\bar{x}=240 \times 195 \mu \mathrm{m}, \mathrm{n}$ $=10$ ), a pseudothecium, black, simple or aggregated, immersed to erumpent or superficial, globose to obpyriform, with inconspicuous ostiole. Peridium 35-50 $\mu \mathrm{m}$ thick at the sides, composed of cells of textura angularis, comprising two layers, outer layer reddish brown to pale brown, thick-walled, inner layer comprising 3-5 cell layers, light brown to hyaline, thin-walled. Hamathecium comprising trabeculate, hypha-like pseudoparaphyses. Asci $62-95 \times 8-11 \mu \mathrm{m}(\bar{x}=70 \times 10 \mu \mathrm{m}, \mathrm{n}=$ 15 ), 8-spored, bitunicate, hyaline, cylindrical, apically rounded with an ocular chamber, with a short furcate pedicel. Ascospores 13-17.5 $\times 4.5-6 \mu \mathrm{m}(\bar{x}=15 \times 5 \mu \mathrm{m}, \mathrm{n}=25)$, overlapping 1-2seriate, ellipsoid to fusiform, brown to reddish brown, 1-septate with conspicuous brown median septum, constricted at the septum, asymmetrical with upper cell slightly wider than lower cell, apiculate, smooth-walled. Asexual morph: Undetermined.

Material examined - USA, North Carolina, behind N. C. Dept. Agr. Nursery Inspection Station, one mile west of Linville, Avery Co., on apothecia of Pestalopezia rhododendri on leaves of Rhododendron maximum L. (Ericaceae), 21 March 1972, Neli Lapp (DAOM 139001, holotype of Didymosphaeria atroseptata).

Testudinaceae Arx, Persoonia 6(3): 366 (1971)

The family Testudinaceae was introduced by von Arx (1971) and formerly comprised Argynna, Lepidosphaeria, Neotestudina, Pseudophaeotrichum and Testudina (type genus). Their characteristics are "astomatous ascomata with a dark peridium, which is often made up of plates, with bitunicate asci, and dark 2-celled ascospores, about $10 \mu \mathrm{m}$ long" (von Arx 1971). Hawksworth (1979) accepted nine genera and provided a key to the genera. Ulospora was later introduced in Testudinaceae (Hawksworth 1979). Argynna was transferred to the family Argynnaceae by Shearer \& Crane (1980). Lumbsch \& Huhndorf (2010) listed four genera in the family. Hyde et al. (2013) accepted five genera in a key to genera of this family. Angustospora was subsequently established in Testudinaceae ( $\mathrm{Li}$ et al. 2016). Wijayawardene et al. (2018) accept seven genera. The results of DNA sequence-based phylogenies of some genera in Testudinaceae were presented in Kruys et al. (2006), Schoch et al. (2009), Suetrong et al. (2009), Zhang et al. (2009b), but they were based on mostly unverified cultures. A synopsis of genera in Testudinaceae was provided in Wanasinghe et al. (2017). The taxonomic placement should be confirmed with verified cultures.

Lepidosphaeria Parg.-Leduc, C. r. hebd. Séanc. Acad. Sci., Paris, Sér. D 270: 2786 (1970)

Saprobic isolated from soil. Sexual morph: Ascomata cleistothecial, black, simple or aggregated, immersed to erumpent or superficial, globose to subglobose. Hamathecium comprising numerous branched, filiform, hypha-like, septate, pseudoparaphyses, embedded in a gelatinous matrix. Asci 8-spored, bitunicate, hyaline, elongate-clavate, with a long pedicel, thick-walled, apically rounded, lacking an evident ocular chamber. Ascospores overlapping 2-3-seriate, ornamented, finely echinulate, oblong, tuberculate, 2-celled, brown to pale brown, septate, darker near the septum, constricted at the septum, minute granules, verrucose, guttulate, with obtuse to rounded ends. Asexual morph: Undetermined.

Type species - Lepidosphaeria nicotiae Parg.-Leduc

Notes - The monotypic Lepidosphaeria was established by Parguey-Leduc (1970) with Lepidosphaeria nicotiae as the type species. Lepidosphaeria nicotiae is and known only from sand (Hawksworth 1979). Characteristics are small ascospores that lack furrows, darker near the septum, and have minute granulate ornamentation (Hawksworth 1979). The genus was accommodated in Testudinaceae following DNA sequence-based phylogenies by Schoch et al. (2009), Zhang et al. (2009b) and Wanasinghe et al. (2017). 

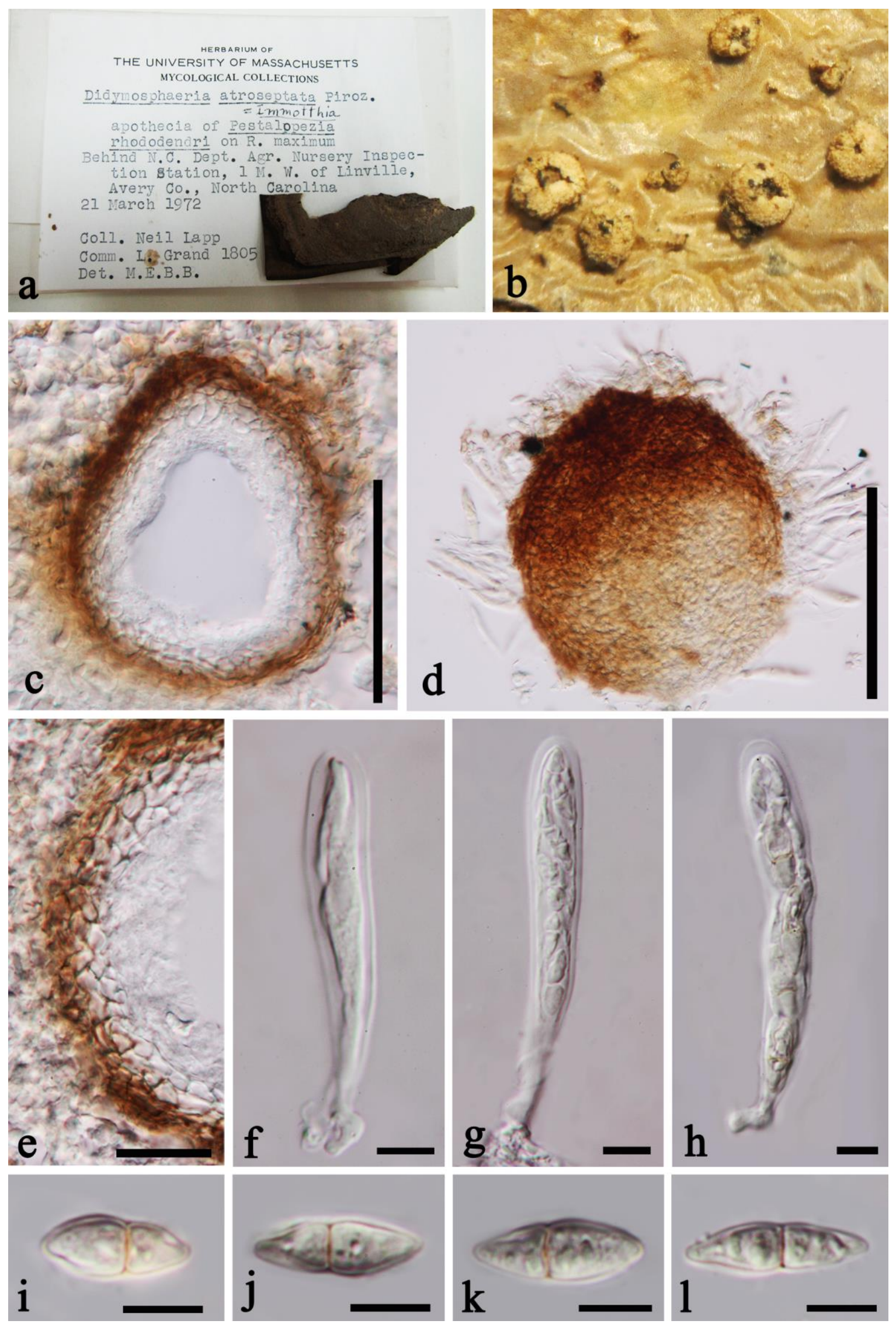

Figure 29 - Immotthia atroseptata (DAOM 139001, holotype of Didymosphaeria atroseptata). a Herbarium label and specimen. b Ascomata on apothecia of Pestalopezia rhododendri. c Vertical section through ascoma. d Exterior of ascoma with asci. e Peridium. f Immature ascus. g, h Asci. i-1 Ascospores. Scale bars: c, $d=50 \mu \mathrm{m}, \mathrm{e}=20 \mu \mathrm{m}, \mathrm{f}-1=5 \mu \mathrm{m}$. 
Saprobic isolated from soil. Sexual morph: Ascomata 345-490 $\mu \mathrm{m}$ high $\times 375-613 \mu \mathrm{m}$ diam. $(\bar{x}=385 \times 505 \mu \mathrm{m}, \mathrm{n}=10)$, cleistothecial, black, simple or aggregated, immersed to erumpent or superficial, globose to subglobose. Peridium dark, subdivided into plates. Hamathecium comprising numerous 1.5-3.5 $\mu \mathrm{m}$ diam., branched, filiform, hyphal-like, septate pseudoparaphyses, embedded in a gelatinous matrix. Asci 50-79×9.5-15 $\mu \mathrm{m}(\bar{x}=63 \times 12 \mu \mathrm{m}, \mathrm{n}=20), 8$-spored, bitunicate, hyaline, elongate-clavate, apically rounded, pedicellate, with a long stalk, thick-walled, lacking an evident ocular chamber. Ascospores 8-10 $\times$ 4.5-7 $\mu \mathrm{m}(\bar{x}=9 \times 6 \mu \mathrm{m}, \mathrm{n}=30), 2$-3-seriate, ornamented, finely echinulate, oblong, tuberculate, brown to pale brown, 1-septate, darker near the septum, constricted at the septum, minute granules, verrucose, guttulate, with obtuse to rounded ends. Asexual morph: Undetermined.

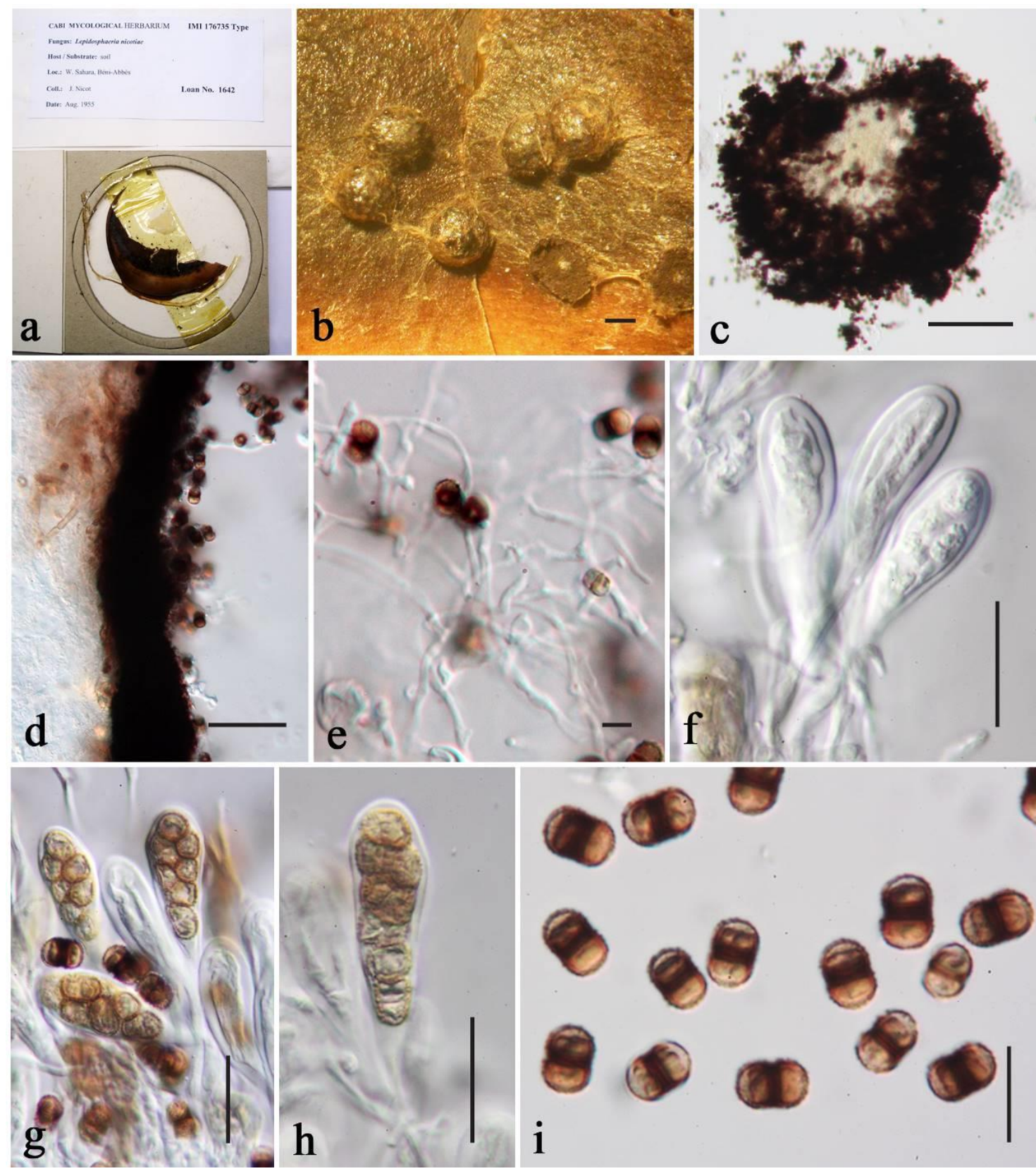

Figure 30 - Lepidosphaeria nicotiae (IMI 176735, holotype). a Herbarium label and habit on dry culture. b Appearance of ascomata on dry culture. c Vertical section of ascoma. d Peridium. e Pseudoparaphyses and ascospores. f Immature asci. g, h Mature asci. i Ascospores. Scale bars: $\mathrm{b}, \mathrm{c}=200 \mu \mathrm{m}, \mathrm{d}=50 \mu \mathrm{m}, \mathrm{e}=5 \mu \mathrm{m}, \mathrm{f}-\mathrm{h}=20 \mu \mathrm{m}, \mathrm{i}=10 \mu \mathrm{m}$. 
Material examined - AFRICA, Northern Africa, Western Sahara, Béni-Abbés, from sandy soil, August 1955, J. Nicot (IMI 176735, holotype).

Neotestudina Segretain \& Drestombes, C. r. hebd. Séanc. Acad. Sci. Paris 253: 2579 (1961)

Saprobic isolated from soil. Sexual morph: Ascomata cleistothecial, black, simple or aggregated, scattered, immersed to erumpent or superficial, globose to subglobose. Hamathecium comprising numerous, branched, filiform, hyaline, hyphal-like, septate pseudoparaphyses, embedded in a gelatinous matrix. Asci 8-spored, bitunicate, obovate or nearly sphaerical, apically rounded, pedicellate, thick-walled. Ascospores 1-seriate or crowded, ornamented, glabrous, ellipsoid, brown to pale brown, 1-septate, not darker near the septum, with rounded ends, smoothwalled. Asexual morph: Undetermined.

Type species - Neotestudina rosatii Segretain \& Destombes

Notes - Segretain \& Destombes (1961) introduced the genus Neotestudina based on Neotestudina rosatii as the type species. Neotestudina is characterized by ascomata that are superficial, cleistothecioid, black 100 to $200 \mu \mathrm{m}$ diam. and globose, which split from an opening. The peridium is smooth, multilayered, and pseudoparenchymatous. Asci are 4- or 8-spored, bitunicate, broadly ellipsoidal, and cylindrical or oblong, forming laterally on ascogenous hyphae. Pseudoparaphyses are sparse and trabeculate. Ascospores are dark brown, ellipsoid, 1-septate, with a small germ pore at each end, uniseriate or crowded in the asci (Howard 1983, 2002, Hawksworth 1979, Barr 1990, Hyde et al. 2013). However, we could not clearly see a germ pore at each end of ascospores from the type specimen. The genus has three species epithets (Index Fungorum 2018). Neotestudina rosatii has a wide distribution in many countries including Australia, Cameroun, Guinea, India and Nigeria (Hawksworth 1979). It is recorded as a human pathogen (Hawksworth et al. 1988, Pilsczek \& Augenbraun 2007, Taylor 2015). A DNA based phylogeny showed that Neotestudina rosatii (CBS 690.82) resides in Testudinaceae (Kruys et al. 2006, Suetrong et al. 2009, Wanasinghe et al. 2017).

Neotestudina rosatii Segretain \& Drestombes, C. r. hebd. Séane. Acad. Sci. Paris 253: 2579 (1961)

三 Zopfia rosatii (Segretain \& Destombes) D. Hawksw. \& C. Booth, Mycol. Pap. 135: 27

= Pseudodelitschia coriandri J.N. Kapoor, Bahl \& S.P. Lal [as 'corianderi'], Kavaka 3: 127 (1976)

= Pseudophaeotrichum sudanense Arx, E. Müll. \& C. Stoll, Nova Hedwigia 17: 84 (1969)

Index Fungorum number: IF335143; Facesoffungi number: FoF04644

Pathogenic and saprobic on humans and soil, respectively. Sexual morph: Ascomata cleistothecial, black, simple or aggregated, scattered, immersed to erumpent or superficial, globose. Peridium outer layers thick-walled, black to reddish, composed of textura angularis cells, inner layers thin-walled, pale brown to hyaline, composed of prismatica cells. Ascospores 9-12 $\times 6-9$ $\mu \mathrm{m}(\bar{x}=10.5 \times 7 \mu \mathrm{m}, \mathrm{n}=30), 1$-seriate or crowded, glabrous, ellipsoid, brown, 1-septate, with rounded to obtuse ends, smooth-walled. Asexual morph: Undetermined.

Material examined - SUDAN, Wad Madani, from soil, 14 November 1966, A. Riggenbach (IMI 173129, holotype = ex-isotype of Pseudophaeotrichum sudanense).

Ulospora D. Hawksw., Malloch \& Sivan., in Hawksworth, Can. J. Bot. 57(2): 96 (1979)

Saprobic on dead leaves. Sexual morph: Ascomata cleistothecial, black, simple, scattered, erumpent to superficial, globose to subglobose, carbonaceous, pseudoparenchymatous, without ostiole. Peridium composed of textura angularis cells comprising two layers, outer layer comprising black, thick-walled cells, inner layer comprising hyaline, thin-walled cells. Hamathecium numerous branched, filiform, hyphal-like, septate pseudoparaphyses, embedded in a gelatinous matrix. Asci 8-spored, bitunicate, hyaline, ovoid to pyriform, apically rounded, pedicellate, thick-walled. Ascospores glabrous, ellipsoid, brown to dark brown, septate, 1-septate, 
constricted at the septum, with rounded ends, guttulate, with germ-slits, smooth-walled. Asexual morph: Undetermined.

Type species - Ulospora bilgramii (D. Hawksw., C. Booth \& Morgan-Jones) D. Hawksw., Malloch \& Sivan.

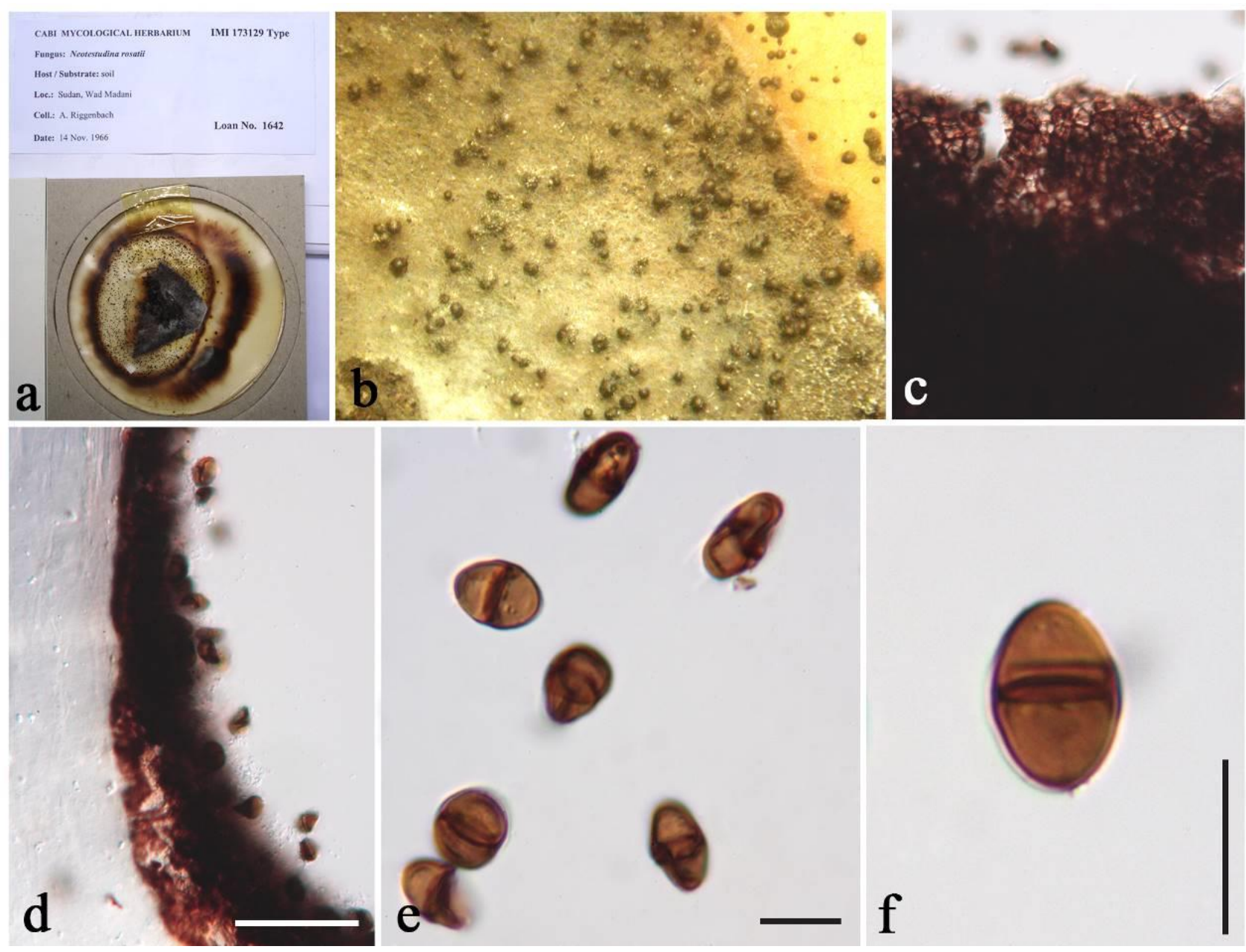

Figure 31 - Neotestudina rosatii (IMI 173129, holotype). a Herbarium label and habit on dry culture. $b$ Appearance of ascomata on dry culture. c, $d$ Peridium. e, f Ascospores. Scale bars: $d=40$ $\mu \mathrm{m}, \mathrm{e}, \mathrm{f}=10 \mu \mathrm{m}$.

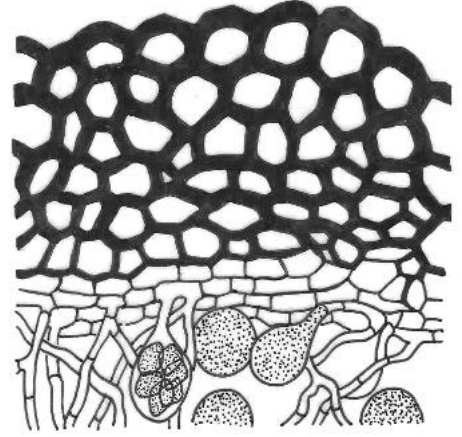

a

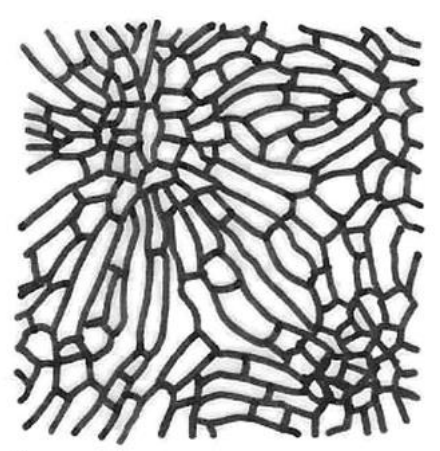

b
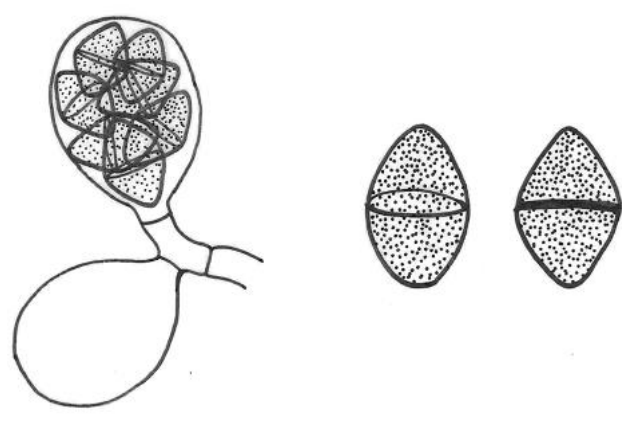

d

Figure 32 - Neotestudina rosatii (redrawn from Howard 2002, Page 460, Fig. 109). a Cortical, subcortical, and ascogenous tissues. b Surface view of the peridium. c Asci with ascospores. $\mathrm{d}$ Ascospores. Scale bars: $\mathrm{a}=30 \mu \mathrm{m}, \mathrm{b}=40 \mu \mathrm{m}, \mathrm{c}=10 \mu \mathrm{m}, \mathrm{d}=5 \mu \mathrm{m}$. 
Notes - Ulospora was introduced with Ulospora bilgramii (三 Zopfia bilgramii D. Hawksw., C. Booth \& Morgan-Jones) as the type species in Testudinaceae by Hawksworth (1979). The type species was originally described from Cassia simea. It is characterized by ascomata that are subglobose, black, non-ostiolate, carbonaceous, and pseudoparenchymatous. Asci are ovoid to pyriform, bitunicate, evanescent, and irregularly arranged. Ascospores are 1-septate, brown, smooth-walled, with three to six (most commonly five) longitudinal fissures (Hawksworth 1979). Mugambi \& Huhndorf (2009), Suetrong et al. (2009), Hyde et al. (2003) and Wanasinghe et al. (2017) grouped an unverified culture of U. bilgramii (CBS 101364) in Testudinaceae based on phylogenetic analysis. Lumbsch \& Huhndorf $(2007,2010)$ and Wijayawardene et al. (2018) listed Ulospora in Testudinaceae.

Ulospora bilgramii (D. Hawksw., C. Booth \& Morgan-Jones) D. Hawksw., Malloch \& Sivan., Can. J. Bot. 57(2): 96 (1979)

Fig. 33

三Zopfia bilgramii D. Hawksw., C. Booth \& Morgan-Jones, Mycol. Pap. 135: 10 (1974)

Index Fungorum number: IF325237; Facesoffungi number: FoF04645

Saprobic on dead leaves of Cassia simea. Sexual morph: Ascomata 120-175 $\mu \mathrm{m}$ high $\times 135$ $230 \mu \mathrm{m}$ diam. $(\bar{x}=145 \times 175 \mu \mathrm{m}, \mathrm{n}=10)$, cleistothecial, black, simple, scattered, erumpent to superficial, globose to subglobose, carbonaceous, pseudoparenchymatous, without ostiole. Peridium 25-50 $\mu \mathrm{m}$ thick, composed of textura angularis cells comprising two layers, outer layer comprising black, thick-walled cells, inner layer comprising hyaline, thin-walled cells. Hamathecium comprising numerous, branched, filiform, hypha-like, septate pseudoparaphyses, embedded in a gelatinous matrix. Ascospores 11-16 $\times 5-9 \mu \mathrm{m}(\bar{x}=13.5 \times 7 \mu \mathrm{m}, \mathrm{n}=30)$, glabrous, ellipsoid, brown to dark brown, 1-septate, constricted at the septum, with rounded ends, guttulate, with germ-slits, smooth-walled. Asexual morph: Undetermined.

Material examined - INDIA, Jodhpur, on Cassia simea Oliv. (Leguminosae), 27 September 1966, K.S. Bilgrami (IMI 120811, holotype).

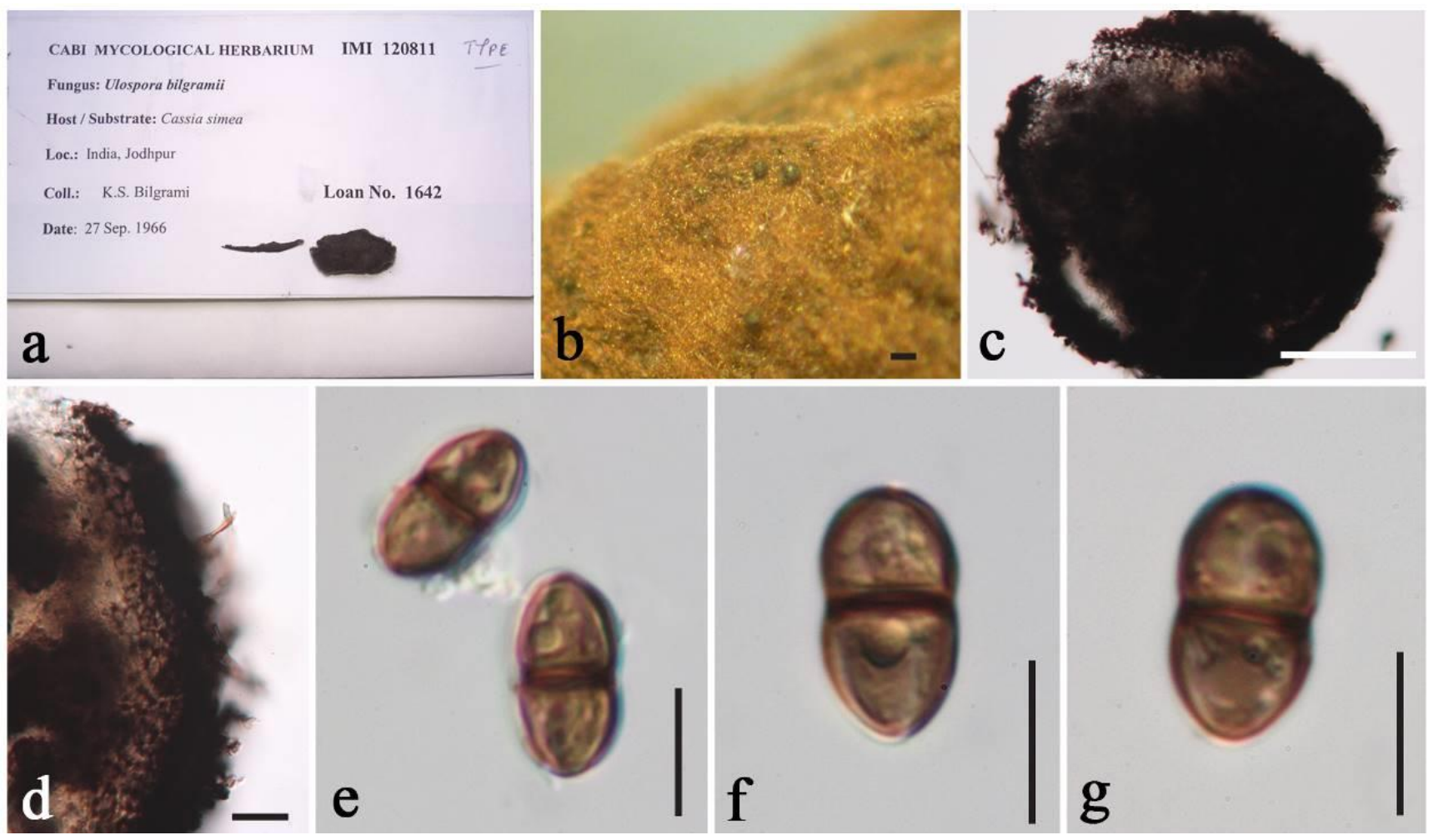

Figure 33 - Ulospora bilgramii (IMI 120811, holotype). a Herbarium label and specimen. $\mathrm{b}$ Appearance of ascomata on host surface. c Vertical section of ascoma. d Peridium. e-g Ascospores. Scale bars: $\mathrm{b}=200 \mu \mathrm{m}, \mathrm{c}=100 \mu \mathrm{m}, \mathrm{d}=20 \mu \mathrm{m}, \mathrm{e}-\mathrm{g}=20 \mu \mathrm{m}$. 


\section{Pleosporales, genus incertae sedis}

Homostegia Fuckel, Jb. nassau. Ver. Naturk. 23-24: 223 (1870) [1869-70]

Lichenicolous. Sexual morph: Ascomata perithecial, carbonaceous, fragile, black, solitary, scattered, or in small groups, grey inside, orbicular to irregular. Ostioles on the stroma surface minute, papillate. Asci 8-spored, oblong to clavate, pedicellate. Ascospores 1-3-septate to multiseptate, sometimes muriform, septa, obovoid to ellipsoid, blunt or curved at the ends. Asexual morph: Undetermined.

Type species - Homostegia adusta Fuckel, $\equiv H$. piggottii (Berk. \& Broome) P. Karst.

Notes - Fuckel (1870) introduced Homostegia with H. adusta as type species. The genus was classified in Dothideomycetes, genera incertae sedis (Wijayawardene et al. 2018). Unfortunately, we did not study type specimen of Homostegia adusta, a species now considered, because of priority as a synonym of $\mathrm{H}$. piggotii. Homostegia piggotii (lectotype) is described herein. We classify Homostegia in Pleosporales, genera incertae sedis and its family placement remains undetermined. Fresh collections, particular of the type species are required to confirm their natural classification.

Homostegia piggotii (Berk. \& Broome) P. Karst., Bidr. Känn. Finl. Nat. Folk 23: 222 (1873)

$\equiv$ Dothidea piggotii Berk. \& Broome, Ann. Mag. nat. Hist., Ser. 2 9: 385 (1852)

Fig. 34

Index Fungorum number: IF150886; Facesoffungi number: FoF04649

Lichenicolous on thallus of Parmelia spp. Sexual morph: Ascomata black, solitary, scattered, or in small groups, discoid, irregular to rounded, easily removed from the substrate, multiloculate, wall black to brownish red, roughened, dehiscence via an irregular slit appearing on upper part of the wall. Locules globose to subglobose, forming a single layer within ascostromata. Peridium one layered, composed of highly pigmented cells of textura angularis, reddish brown. Hamathecium dense with cellular, hyaline, septate pseudoparaphyses. Asci 55-64 $\times 16-20 \mu \mathrm{m}(\bar{x}=61 \times 17, \mathrm{n}=$ 20), 8-spored, bitunicate, fissitunicate dehiscence not observed, obovoid to broadly cylindrical, with short, broad, hamate-shaped pedicel. Ascospores $18-22 \times 7-10 \mu \mathrm{m}(\bar{x}=20 \times 9, \mathrm{n}=20)$, partially overlapping, fusiform to ellipsoid to broadly ellipsoid, brown to reddish brown, 3 transverse septa, constricted at septa, slightly curved, smooth-walled. Asexual morph: Undetermined.

Material examined - UK, Caernarvonshire, on thallus of Parmelia omphalodes (L.) Ach. (Parmeliaceae), 1849, anon. (ex herb. H. Piggot) (K(M) 176033, lectotype of Dothidea piggotii).

Venturiales Y. Zhang ter, C.L. Schoch \& K.D. Hyde, in Zhang, Crous, Schoch, Bahkali, Guo \& Hyde, Fungal Diversity 51(1): 251 (2011)

Venturiaceae E. Müll. \& Arx ex M.E. Barr, Mycologia 71(5): 947 (1979)

Venturiaceae has been formerly placed in the order Pleosporales based on its "Pleospora type of centrum and bitunicate asci" (Barr 1968, 1979). However, phylogenic studies did not support Venturiaceae in Pleosporales (Kodsueb et al. 2006b, Kruys et al. 2006, Winton et al. 2007). Zhang et al. (2011) introduced Venturiales which also includes the family Sympoventuriaceae. The members of Venturiaceae are saprobes, parasites and pathogens on living or dead plants (Scholtysik et al. 2013, Ibrahim 2014, Ibrahim et al. 2016, Zhang et al. 2016). Twelve genera are accommodated in the Venturiaceae (Wijayawardene et al. 2018).

Venturia E. Müll. \& Arx ex M.E. Barr 1979, Mycologia 71: 947 (1979)

Parasitic or saprobic on dicotyledonous leaves. Sexual morph: Ascomata pseudothecia, black, solitary, scattered, small, initially immersed, becoming erumpent, globose, with setae on top, ostiole papillate. Setae arising from the top of ascomata, black to dark brown, erect to flexuous, unbranched, septate, swollen at the base, smooth. Peridium composed of cells of textura angularis, comprising two layers, outer layer; dark brown, thick-walled cells, inner layer comprising 2-3 cell layers, light brown to hyaline. Hamathecium of hyaline, septate, hyphae-like pseudoparaphyses. Asci 8-spored, bitunicate, fissitunicate, oblong to obclavate, thick-walled, knob-like pedicel or 
pedicel lacking, apically rounded with indistinct ocular chamber. Ascospores ellipsoid, olivaceous, thin-walled, 1-septate, initially hyaline, becoming pale brown, upper cell shorter and wider than lower cell, slightly constricted at septum, smooth-walled, verrucose. Asexual morph: hyphomycetous (Wijayawardene et al. 2017a, Shen et al. 2016).

Type species - Venturia inaequalis (Cooke) G. Winter

$\equiv$ Sphaerella inaequalis Cooke 1866

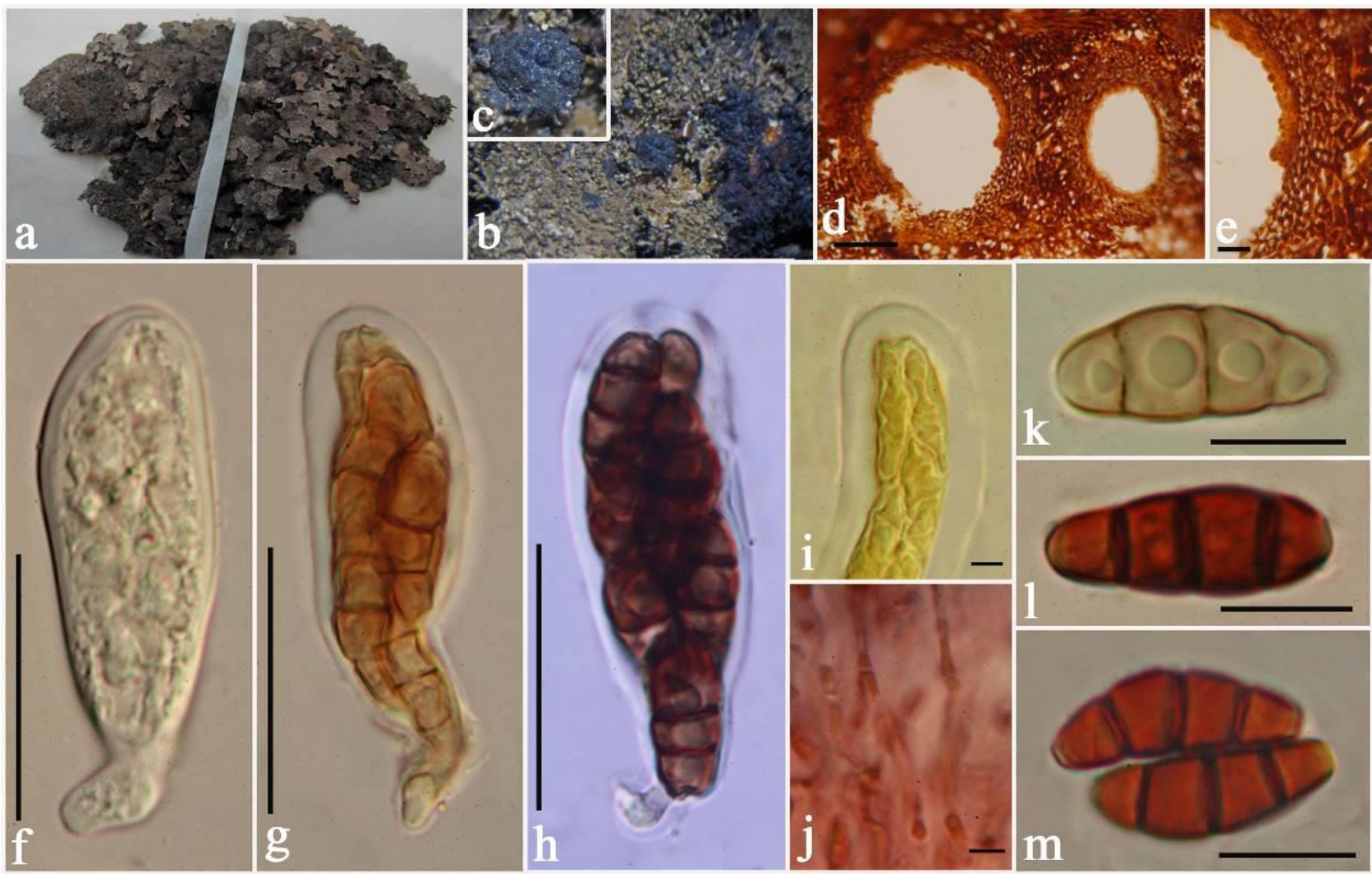

Figure 34 - Homostegia piggotii (K(M) 176033, lectotype of Dothidea piggotii). a Host substrate. b Ascomata on host substrate. c Close up of ascoma. d Section of ascomata. e Close up of the peridium. $\mathrm{f}-\mathrm{h}$ Asci. i Asci stained in Melzer's reagent. $\mathrm{j}$ Pseudoparaphyses stained in Congo red. $\mathrm{k}-\mathrm{m}$ Ascospores with 3-septa. Scale bars: $\mathrm{d}=100 \mu \mathrm{m}, \mathrm{e}=30 \mu \mathrm{m}, \mathrm{f}-\mathrm{h}=30 \mu \mathrm{m}, \mathrm{i}=10 \mu \mathrm{m}, \mathrm{j}=5$, $\mathrm{k}-\mathrm{m}=10 \mu \mathrm{m}$.

Notes - Venturia was described by De Notaris (1844) to accommodate $V$. rosea and $V$. dianthi but no type species was designated. Later, many species of Venturia were introduced. Saccardo (1882) amended the description of Venturia, and excluded both $V$. rosea and $V$. dianthi, and designated $V$. inaequalis (Cooke) G. Winter as the neotype species. Species of Venturia are widely distributed in various plant families such as Caprifoliaceae and Oleaceae (Ibrahim et al. 2016, Zhang et al. 2016). They can be saprobes, parasites, endophytes or pathogens (Scholtysik et al. 2013, Ibrahim 2014). Venturia inaequalis causes apple scab (Vaillancourt \& Hartman 2000, Ward 2012), while V. pyrina causes pear scab (Sokolova et al. 2014). The sexual morph of Venturia is commonly formed on overwintered litter, while the asexual morph can appear soon after leaf fall, or in the case of pathogens have already formed in leaf spots during the vegetation period (Ibrahim et al. 2016). The sexual morph are pseudothecia immersed in the host tissue and becoming erumpent. Many species have setae around the ostiole (Sivanesan 1977, 1984).

Venturia chlorospora (Ces.) P. Karst., Bidr. Känn. Finl. Nat. Folk 23: 189 (1873)

Fig. 35

三Sphaeria chlorospora Ces., Erb. critt. Ital., Ser. 1, fasc. 2: no. 296 (1859)

Index Fungorum number: IF199040; Facesoffungi number: FoF04646 
Parasitic or saprobic on dicotyledonous leaves. Sexual morph: Ascomata 60-115 $\mu \mathrm{m}$ high $\times$ 65-105 $\mu \mathrm{m}$ diam. $(\bar{x}=90 \times 97 \mu \mathrm{m}, \mathrm{n}=15)$, pseudothecia, black, solitary, scattered, initially immersed, becoming erumpent, globose, with setae on top, ostiole papillate. Setae up to $120 \mu \mathrm{m}$ long, 5-11 $\mu \mathrm{m}$ wide at the base, $0.4-2 \mu \mathrm{m}$ wide at the apex, arising from the top of ascomata, black to dark brown, erect to flexuous, unbranched, septate, swollen at the base, smooth. Peridium composed of textura angularis cells, comprising two layers, outer layer dark brown, thick-walled cells, inner layer; comprising 2-3 cell layers, light brown to hyaline. Hamathecium of $1-2.5 \mu \mathrm{m}$ wide, hyaline, septate, hyphae-like pseudoparaphyses. Asci 42-66 × 12-16 $\mu \mathrm{m}(\bar{x}=54 \times 14 \mu \mathrm{m}, \mathrm{n}$ $=20$ ), 8-spored, bitunicate, fissitunicate, oblong to obclavate, thick-walled, knob-like pedicel or pedicel lacking, apically rounded with indistinct ocular chamber. Ascospores $12-16 \times 5-7 \mu \mathrm{m}(\bar{x}=$ $13 \times 6, n=20$ ), ellipsoid, olivaceous, thin-walled, 1-septate, initially hyaline, becoming pale brown, upper cell shorter and wider than lower cell, slightly constricted at septum, smooth-walled, verrucose. Asexual morph: Undetermined.

Material examined - GERMANY, on leaves of Salix sp., 25 May 2011, René Jarling.

Trypetheliales Lücking, Aptroot \& Sipman, in Aptroot, Lücking, Sipman, Umaña \& Chaves, Biblthca Lichenol. 97: 13 (2008)

Polycoccaceae Ertz, Hafellner \& Diederich, in Ertz, Diederich, Lawrey, Berger, Freebury, Coppins, Gardiennet \& Hafellner, Fungal Diversity 74: 82 (2015)

Ertz et al. (2015a) introduced the family Polycoccaceae to accommodate two genera, Clypeococcum and Polycoccum in Trypetheliales based upon morphological and molecular data. Polycoccum is designated as the type genus (Ertz et al. 2015a). Clypeococcum and Polycoccum were previously listed in Dacampiaceae (Lumbsch \& Huhndorf 2010, Hyde at al. 2013, Wijayawardene et al. 2014). Polycoccaceae species are lichenicolous fungi (Hafellner 2015, Ertz et al. 2015a). They are characterized by "ascomata perithecioid, subglobose to obpyriform, solitary or in group, united by a clypeus or enclosed in galls, immersed, dark brown to black, ostiolate, with pore-like opening, thick peridial walls, arranged in a textura angularis; hamathecium anastomosed, hyphal filaments, trabeculate pseudoparaphyses with hymenial gel I+ blue to violet or unchanged; asci 2-8-spored, bitunicate, fissitunicate, cylindrical to subclavate and ascospores brown to dark brown, ellipsoid, 1-septate, smooth or delicately verruculose" (Ertz et al. 2015a). Phylogenetic analyses of LSU sequence data showed that Polycoccaceae formed a sister lineage with Trypetheliaceae in Trypetheliales, Dothideomycetes but other members of Polycoccum s. lat. were placed outside Polycoccaceae and allied together in the Pleosporales (Ertz et al. 2015a).

\section{Clypeococcum D. Hawksw., J. Linn. Soc., Bot. 75: 196 (1977)}

Lichenicolous. Sexual morph: Pseudothecia immersed to semi-immersed under a black clypeus, visible as rounded or patch-like spots on the lichen thallus, clustered, rarely scattered, globose to subglobose, or ovoid, dark brown to black, ostiole central, discrete to gaping, with porelike opening. Peridium thin-walled, composed of 1-3 layers of brown to dark brown, pseudoparenchymatous cells, arranged in a textura angularis. Hamathecium composed of dense, filiform, branched, distinct septate, anastomosed, pseudoparaphyses, embedded in a hyaline gelatinous matrix. Asci 8-spored, bitunicate, ovoid to subcylindrical, usually short-pedicellate, apically rounded and thickened, with rounded ocular chamber. Ascospores overlapping 1-3-seriate, hyaline when young, becoming brown to dark brown when mature, ellipsoidal to fusiform, with rounded apex, 1-septate, constricted at septum, rough-walled, minutely verruculose. Asexual morph: Undetermined.

Type species - Clypeococcum cladonema (Wedd.) D. Hawksw.

Notes - Clypeococcum was introduced as a monotypic genus by Hawksworth (1977) to accommodate Lecidea cladonema Wedd., which was reported as a parasite on Parmelia delisei (Duby) Nyl. by Weddell (1874). There are 13 epithets listed in this genus (Index Fungorum 2018). Clypeococcum can be distinguished from Polycoccum Saut. ex Körb. based on its pseudothecial walls comprising textura intricata which are thickened around the ostiole and its pseudothecia 
forming as groups united by a common clypeus (Hawksworth 1977, Hawksworth \& Diederich 1988, Ertz et al. 2015a, Etayo 2017). Polycoccum forms clearly pseudothecial walls and its pseudothecia often forms on the host thallus, with a tendency to induce galls (Hawksworth 1977, Hawksworth \& Diederich 1988, Ertz et al. 2015a, Etayo 2017). Based on morphological characters, the genus was placed in the Pleosporaceae (Pleosporales) by Hawksworth (1977). However, it has been transferred to Dacampiaceae and accepted by subsequent authors (Lumbsch \& Huhndorf 2010, Hyde et al. 2013, Wijayawardene et al. 2014, 2018, Pirogov 2015, Jaklitsch et al. 2016). Ertz et al. (2015a) sequenced two representative species Clypeococcum placopsiiphilum and $C$. psoromatis and treated Clypeococcum in a new family Polycoccaceae (Trypetheliales, Dothideomycetes) based on molecular phylogeny using nuLSU sequences. However, phylogenetic affinity of Clypeococcum still needs to be confirmed by the sequencing of its type species (Ertz et al. 2015a).

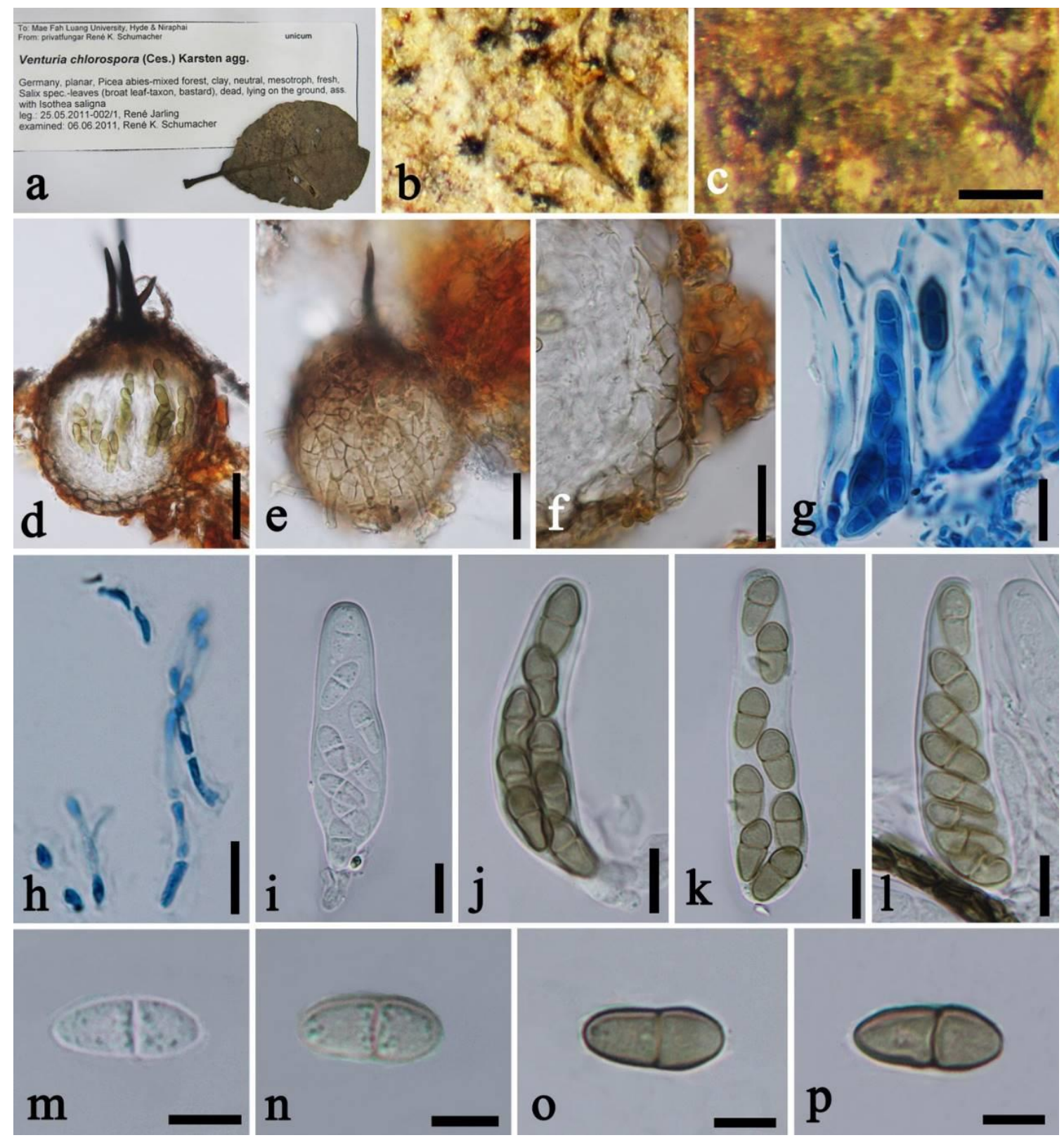

Figure 35 - Venturia chlorospora. a Material label and specimen. b Ascomata on substrate. c Close up of ascomata on substrate. $d$ Vertical section through ascoma with seta. e Exterior of ascoma with setae. f Peridium. g Asci with pseudoparaphyses. h Pseudoparaphyses. i Immature ascus. j-1 Mature asci. m Immature ascospore. $\mathrm{n}-\mathrm{p}$ Ascospores. Note: $\mathrm{g}$, $\mathrm{h}$ stained in lactophenol cotton blue. Scale bars: $\mathrm{c}=100 \mu \mathrm{m}, \mathrm{d}, \mathrm{e}=30 \mu \mathrm{m}, \mathrm{f}=10 \mu \mathrm{m}, \mathrm{g}-1=10 \mu \mathrm{m}, \mathrm{m}-\mathrm{p}=5 \mu \mathrm{m}$. 
The type species, Clypeococcum cladonema can be distinguished from other Clypeococcum species by having smaller ascospores, 8 -spored asci and forming pseudothecia immersed in patchlike clypeus. The species was reported as a parasite causing little damage on the thallus of Parmelia delisei, Cetrelia olivetorum (Ach.) Culb. \& C. Culb and Xanthoparmelia pulla (Ach.) O. Blanco et al. (Hawksworth 1977, Pirogov 2015, Etayo 2017). Hawksworth (1977) examined the type specimen of $C$. cladonema from PC and mentioned that the species has hyphal-like pseudothecial walls (textura intricata) but becoming pseudoparenchymatous at maturity, with subcylindrical, short-pedicellate asci. However, we examined the isotype of $C$. cladonema from $\mathrm{S}$ and found that the species forms pseudothecial walls in a textura angularis, pseudoparenchymatous cells, with subcylindrical to ovoid asci.

Clypeococcum cladonema (Wedd.) D. Hawksw., Bot. J. Linn. Soc. $75(2): 197$ (1977)

Fig. 36

三Lecidea cladonema Wedd., Bull. Soc. bot. Fr. 21: 345 (1874)

Index Fungorum number: IF311399; Facesoffungi number: FoF04647

Lichenicolous on Parmelia delisei. Sexual morph: Pseudothecia 80-120 $\mu \mathrm{m}$ high, 80-120 $\mu \mathrm{m}$ diam. [60-150 $\mu \mathrm{m}$ diam., Hawksworth 1977], immersed under the clypeus [1.5 mm diam., Hawksworth 1977], visible as rounded or patch-like black spots on the lichen thallus, clustered, rarely scattered, globose to subglobose, or ovoid, dark brown to black, ostiole central, discrete to gaping, with pore-like opening. Peridium 8-25 $\mu \mathrm{m}$ wide [15-25 $\mu \mathrm{m}$ wide, Hawksworth 1977], thin-walled, composed of 1-3 layers of brown to dark brown, pseudoparenchymatous cells, arranged in a textura angularis. Hamathecium 1-2 $\mu \mathrm{m}$ wide [2.5-3.5 $\mu \mathrm{m}$ wide, Hawksworth 1977], composed of dense, filiform, branched, distinctly septate, anastomosed pseudoparaphyses, embedded in a hyaline gelatinous matrix. Asci 30-40 × 8-16 $\mu \mathrm{m}[60-70 \times 10-14$, Hawksworth 1977], 8-spored, bitunicate, ovoid to subcylindrical, usually short-pedicellate, apically rounded and thickened, with rounded ocular chamber. Ascospores $(12-) 15-17 \times(4-) 6-8 \mu \mathrm{m}(\bar{x}=15.2 \times 6.8, \mathrm{n}$ $=10)[(13.5-) 14-16(-18) \times(5.5-) 6-7(-7.5) \mu \mathrm{m}$, Hawksworth 1977], overlapping 1-3-seriate, hyaline when young, becoming brown to dark brown when mature, ellipsoidal to fusiform, with rounded apex, 1-septate, constricted at septum, rough-walled, minutely verruculose. Asexual morph: Undetermined.

Material examined - FRANCE, Languedoc-Rousillon, Hérault, Rochers volcanique Agde, parasite on Parmelia delisei, 1907 (S-F9606, isotype of Lecidea cladonema).

Polycoccum Saut. ex Körb., Parerga lichenol. (Breslau) 5: 470 (1865)

Lichenicolous on various hosts. Sexual morph: Ascomata perithecioid, immersed to semiimmersed, visible as raised, black, shiny spot, enclosed in galls on host thallus, globose to subglobose, dark brown to black, scattered, gregarious in a gall. Ostiole apapillate. Peridium thinto thick-walled, composed of several layers of small to large polyhedral, dark brown to black, pseudoparenchymatous cells, arranged in textura angularis to textura epidermoidea. Hamathecium composed of dense, curly filamentous, richly branched, anastomosed, cellular pseudoparaphyses. Asci 8-spored, bitunicate, subcylindrical to cylindric-clavate, short-pedicellate, apically rounded, with ocular chamber. Ascospores 1-2-seriate, brown to dark brown, obovoid, 1-septate, constricted at septum, mostly upper cell larger than lower cell, smooth-walled. Asexual morph: Reported as coelomycete, forming pycnidia, with simple, oblong to elliptic, smooth-walled conidia (Zhurbenko 2010, Ertz et al. 2015a).

Type species - Polycoccum trypethelioides (Th. Fr.) R. Sant.

Notes - The genus Polycoccum was introduced by Körber (1865) for the single species, $P$. sauteri Körber as the type species (now a synonym of $P$. trypethelioides). The genus was regarded as a synonym of Didymosphaeria Fuckel by Saccardo (1882). However, Polycoccum is differentiated from Didymosphaeria by ascomatal structure and the generic name of Polycoccum was reinstated by Santesson (1960) and (Hawksworth \& Diederich 1988). Polycoccum includes lichenicolous fungi on diverse hosts (Ertz et al. 2015a). Vězda (1969) provided a key to 10 Polycoccum species. Subsequently, Hawksworth \& Diederich (1988) provided a key to Polycoccum 
with 23 accepted species, while 29 epithets were excluded. Additional keys were also provided by Atienza et al. (2003) and Gardiennet (2012). Lawrey \& Diederich (2015) accepted 57 species. New species were introduced regularly in the last decade (Brackel \& Berger 2010, Zhurbenko \& Dillman 2010, Halici et al. 2013, Hafellner 2015). Polycoccum was referred to Pleosporaceae by Eriksson \& Hawksworth (1986). Subsequently, the genus was referred to Dacampiaceae based on morphology (Hawksworth \& Diederich 1988). Ertz et al. (2015a) placed Polycoccum in Polycoccaceae on the basis of morphological and molecular data. Polycoccum is polyphyletic based on nuLSU sequence data in Ertz et al. (2015a). Their result showed that the members of Polycoccum s. lat. were included in the Pleosporales and closely related to lichenicolous Phomalike species in family Phaeosphaeriaceae, while five isolates of Polycoccum s. str. nested together with Clypeococcum in Polycoccaceae. Thus, we give the descriptions and illustrations of type species herein as the foundation to facilitate identification. Our morphological observations were in accordance with the original description.
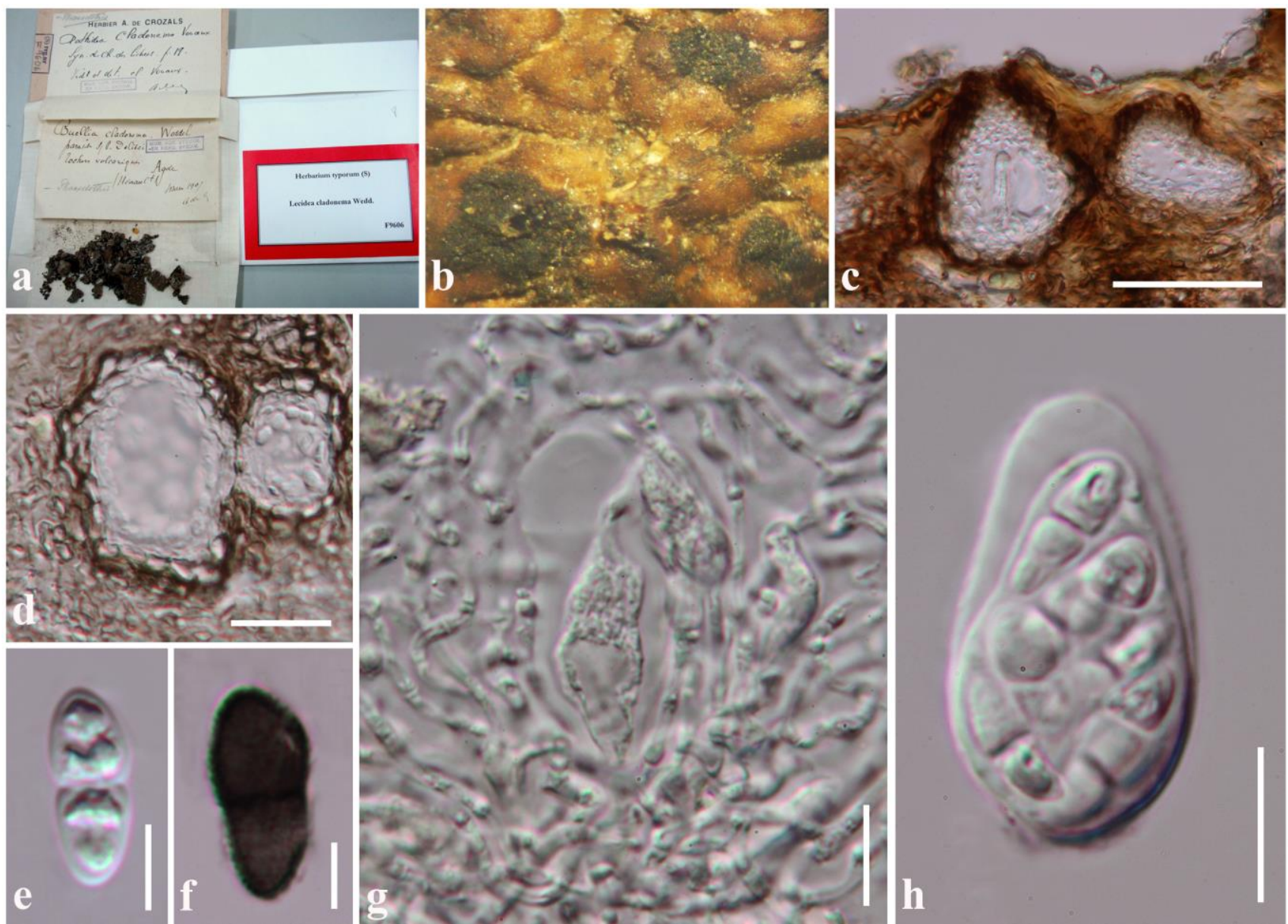

Figure 36 - Clypeococcum cladonema (S-F9606, isotype of Lecidea cladonema). a Herbarium label and specimen. b Dark clypeus visible as patch-like on the thallus surface. c Vertical section through ascoma immersed in the clypeus. d Section through peridium. e Immature ascospore. f Mature ascospore. $g$ Immature ascus embedded in pseudoparaphyses. $\mathrm{h}$ Ascus. Scale bars: $\mathrm{c}=50$ $\mu \mathrm{m}, \mathrm{d}=20 \mu \mathrm{m}, \mathrm{e}, \mathrm{f}=5 \mu \mathrm{m}, \mathrm{g}, \mathrm{h}=10 \mu \mathrm{m}$.

Polycoccum trypethelioides (Th. Fr.) R. Sant., Svensk bot. Tidskr. 54(4): 505 (1960)

Fig. 37

三Diatrype trypethelioides Th. Fr., Nova Acta R. Soc. Scient. upsal., Ser. 3 2(1): 317 (1858)

$\equiv$ Polycoccum sauteri Körb., Parerga lichenol. (Breslau) 5: 470 (1865)

Index Fungorum number: IF207058; Facesoffungi number: FoF04648 

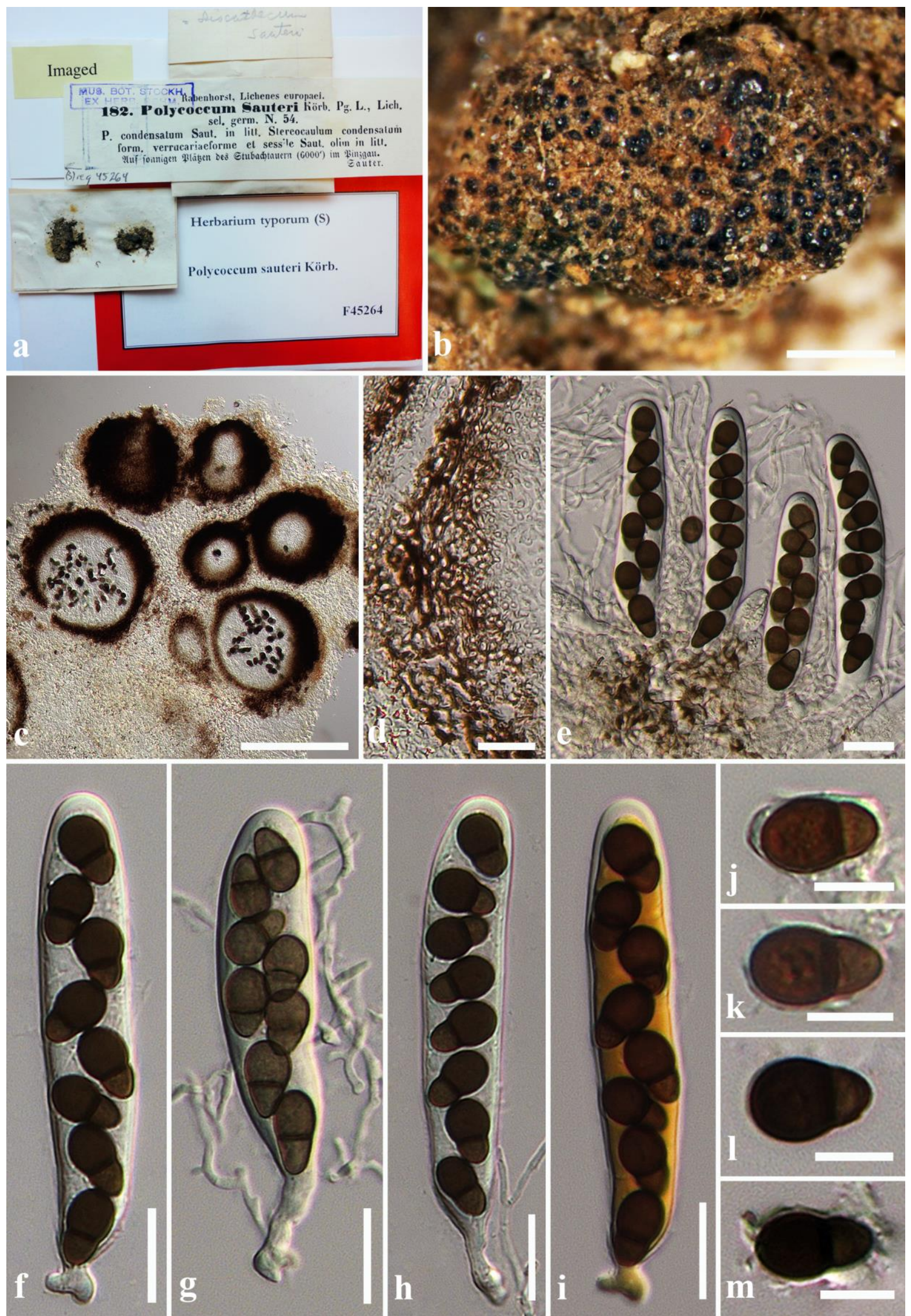

Figure 37 - Polycoccum trypethelioides (S-F45264, holotype of Polycoccum sauteri). a Herbarium label and specimen. b Ascomata immersed in the host thallus. c Section through ascomata. d Peridium. e Asci with pseudoparaphyses. f-h Asci. i Ascus stained in Melzer's reagent. $\mathrm{j}-\mathrm{m}$ Ascospores. Scale bars: $\mathrm{b}=1000 \mu \mathrm{m}, \mathrm{c}=200 \mu \mathrm{m}, \mathrm{d}-\mathrm{i}=20 \mu \mathrm{m}, \mathrm{j}-\mathrm{m}=10 \mu \mathrm{m}$. 
Lichenicolous fungi, occurring on Stereocaulon condensatum Hoffm. Sexual morph: Ascomata 150-280 $\mu \mathrm{m}$ high, 140-250 $\mu \mathrm{m}$ diam., perithecioid, immersed to semi-immersed, visible as raised, black, shiny spot, enclosed in galls on host thallus, globose to subglobose, dark brown to black, scattered, gregarious in galls, ostiolate, apapillate. Peridium 8-35 $\mu \mathrm{m}$ wide, thin- to thickwalled, composed of several layers of pseudoparenchymatous cells, inner layers comprising several cell layers of small, dark brown, thick-walled, polyhedral cells, arranged in a textura angularis, outer layers comprising several cell layers of flattened, dark brown, thick-walled cells, arranged in a textura angularis to textura epidermoidea. Hamathecium 1-3 $\mu \mathrm{m}$ wide, composed of dense, filamentous, richly branched, anastomosed, pseudoparaphyses. Asci 87-140 × 17-26 $\mu \mathrm{m}(\bar{x}=110$ $\times 19.4, \mathrm{n}=20$ ), 8 -spored, bitunicate, subcylindrical to cylindric-clavate, short-pedicellate, apically rounded, with indistinct ocular chamber. Ascospores 13-17 $\times 7-10 \mu \mathrm{m}(\bar{x}=14.7 \times 9.1, \mathrm{n}=30)$, overlapping 1-2-seriate, brown to dark brown, obovoid, 1-septate, constricted at septum, mostly upper cell usually larger than lower cell, smooth-walled. Asexual morph: Undetermined.

Material examined - AUSTRIA, Salzburg, on sunny slopes of the Stubachauern (6000') in Binzgau, on Stereocaulon condensatum, Sauter no. 182 (S-F45264, holotype of Polycoccum sauteri).

\section{Dothideomycetes, families incertae sedis}

Naetrocymbaceae Höhn. ex R.C. Harris, More Florida Lichens, Incl. 10 Cent Tour Pyrenol. (New York): 59 (1995)

This family (as Naetrocymbeen) was originally described by Höhnel (1909b). However, this description was illegitimate as it was not in Latin or in accordance with ICBN rules (Harris 1995), but this taxon continued to be recognized to varying degrees through the 1990's. Batista \& Ciferri (1963) treated the genus Naetrocymbe as part of Capnodiaceae, while Luttrell (1973) regarded Naetrocymbe as questionable and of uncertain taxonomic position. In contrast, Barr (1979) and Eriksson (1981) informally recognized Naetrocymbaceae as a distinct family, albeit, with different circumscriptions. Harris (1995) later validated the family name and included four genera: Jarxia, Leptorhaphis, Naetrocymbe, and Tomasellia. This circumscription is also currently recognized by Lumbsch \& Huhndorf (2010) and Wijayawardene et al. (2018).

Jarxia D. Hawksw., Stud. Mycol. 31: 93 (1989)

Saprobic on dead plant. Sexual morph: Ascomata perithecial, small, solitary, scattered, immersed becoming erumpent, finally superficial, globose to subglobose, top rounded, black to dark brown, membranous, surrounding by septate, dark brown, irregular, branched hyphae, about 3 $\mu \mathrm{m}$ wide, with a short, central ostiole. Peridium thick, composed of one layer of hyaline to brown cells of textura angularis. Hamathecium of gelatinous, hyaline, septate, cellular pseudoparaphyses. Asci 8-spored, bitunicate, clavate, with an ocular chamber. Ascospores elongate-ellipsoid, 1-septate, smooth-walled, upper cell larger but lower cell longer, occasionally guttulate, constricted at the septum, gelatinous sheath not observed. Asexual morph: Undetermined.

Type species - Jarxia thelenula (Müll. Arg.) D. Hawksw.

Notes - Jarxia D. Hawksw comprises two non lichen-forming species. The holotype of Jarxia thelenula was observed on twigs of Gochnatia buchii (Urb.) Jimenez collected in Cuba, however, we examined the syntype on an unidentified plant from same country, which has the same morphology as the holotype (Hawksworth 1989). Jarxia differs from Naetrocymbe, Leptorhaphis and Tomasellia in its superficial ascomata. Naetrocymbe forms clavate to obovoid asci, which separate it from other genera in Naetrocymbaceae. Both Leptorhaphis and Tomasellia have immersed, subglobose and dark brown ascomata and 8-spored, ellipsoid and apically rounded asci with an ocular chamber. However, Leptorhaphis forms fusiform ascospores, which differentiate it from the ellipsoid ascospores of Tomasellia (Hawksworth 1989).

Jarxia thelenula (Müll. Arg.) D. Hawksw., Stud. Mycol. 31: 95 (1989)

Fig. 38

三 Microthelia thelenula Müll. Arg., Bot. Jb. 6: 416 (1885) 
EVerrucaria thelenula Nyl., Flora, Regensburg 59: 364 (1876)

= Kirschsteiniella ciferriana Petr., Annls mycol. 30(3/4): 191 (1932)

Index Fungorum number: IF135893; Facesoffungi number: FoF04650
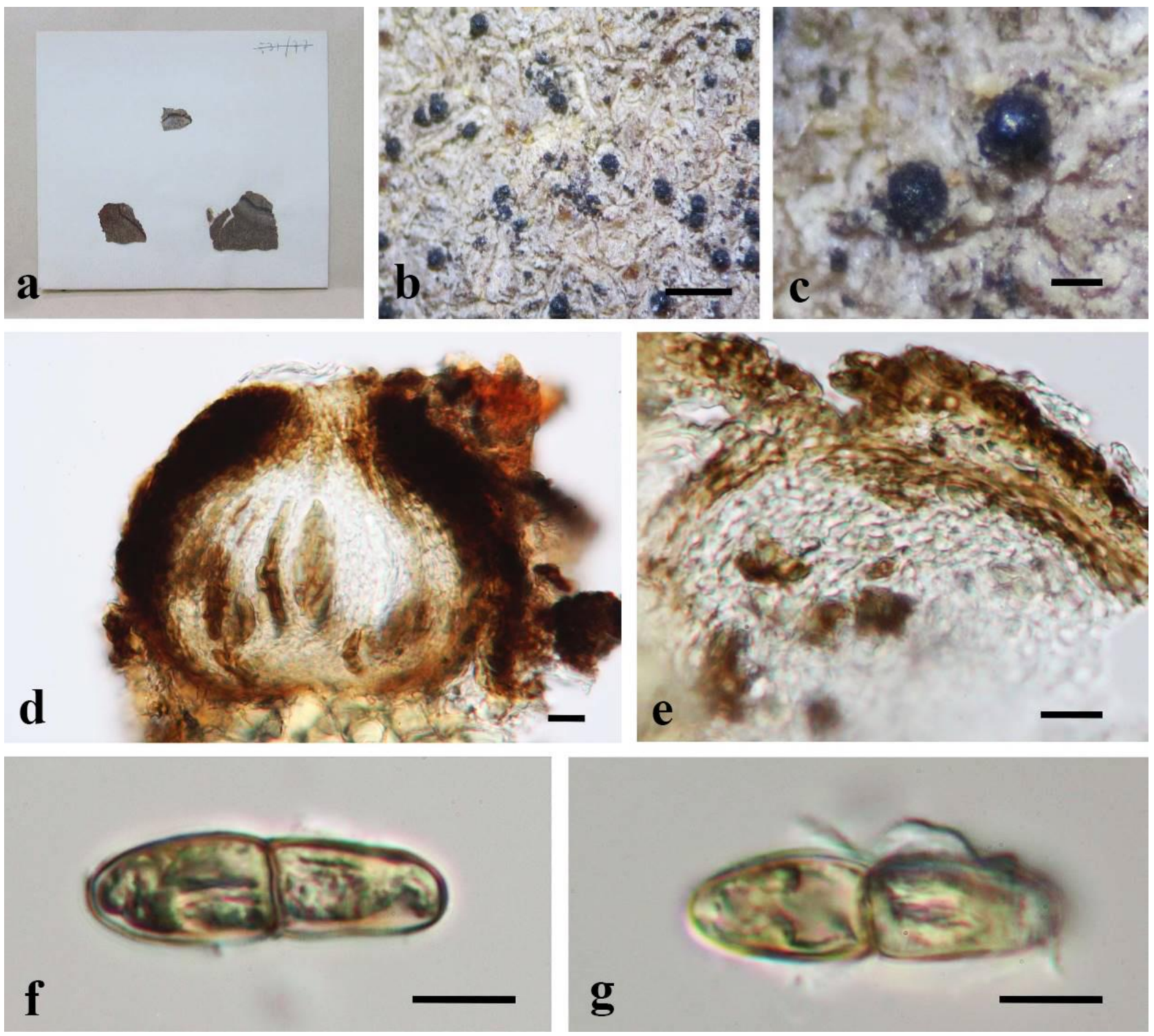

Figure 38 - Jarxia thelenula ( $\mathrm{G}$ 00111325, holotype of Microthelia thelenula). a Herbarium specimen. b, c Appearance of black ascomata on host surface. d Vertical section of ascoma with asci. e Peridium. f, g Ascospores. Scale bars: $b=5 \mathrm{~mm}, \mathrm{c}=100 \mu \mathrm{m}, \mathrm{d}-\mathrm{g}=10 \mu \mathrm{m}$.

Saprobic on dead unidentified plant. Sexual morph: Ascomata perithecial, 100-145 $\mu \mathrm{m}$ diam., 80-100 $\mu \mathrm{m}$ high, small, solitary, scattered, immersed becoming erumpent, finally superficial, globose to subglobose, top rounded, black to dark brown, membranous, surrounding by septate, dark brown, irregular, branched hyphae, about $3 \mu \mathrm{m}$ wide, with a short, central ostiole. Peridium thick, 10-15 $\mu \mathrm{m}$ thick, composed of one layer of hyaline to brown cells of textura angularis. Hamathecium of gelatinous, hyaline, septate, cellular pseudoparaphyses. Asci 45-85 $\times$ 13-17 $\mu \mathrm{m}(\bar{x}=50.4 \times 15.6, \mathrm{n}=20), 8$-spored, bitunicate, clavate, with an ocular chamber. Ascospores $23-26 \times 5.5-8 \mu \mathrm{m}(\bar{x}=25.4 \times 6.3, \mathrm{n}=20), 2$-seriate to irregularly arranged in asci, elongate-ellipsoid, brown to dark brown, 1-septate, smooth-walled, upper cell bigger but lower cell longer, occasionally guttulate, constricted at the septum, gelatinous sheath not observed. Asexual morph: Undetermined. 
Material examined - CUBA, on dead unidentified plant, 1866, C. Wright (G 00111325, Verrucaria thelenula, holotype of Microthelia thelenula).

Leptorhaphis Körb., Syst. lich. germ. (Breslau): 371 (1855)

Lichenicolous, saprobic on dead plant. Thallus not observable. Sexual morph: Ascomata perithecial, small, solitary, scattered, immersed becoming erumpent, finally superficial, globose to subglobose, top rounded, black to dark brown, membranous, ostiole not observed. Peridium thick, composed of one layer of hyaline to brown cells of textura angularis. Hamathecium gelatinous, hyaline, septate, cellular and anastomosing pseudoparaphyses. Asci 8-spored, bitunicate, clavate, with an ocular chamber. Ascospores fusiform, hyaline, 1-septate, guttulate, smooth-walled, not constricted at the septum, gelatinous sheath not observed. Asexual morph: Undetermined.

Type species - Leptorhaphis epidermidis (Ach.) Th. Fr.

Notes - The genus Leptorhaphis was revised by Aguirre-Hudson \& Hawksworth (1987) and Aguirre-Hudson (1991) and eventually restricted to 12 species occurring in temperate-boreal regions of the Northern Hemisphere. These typically occur on bark and exhibit a high level of host specificity (Aguirre-Hudson 1991, 2009, Aguirre-Hudson et al. 2002). Additional species have since been described including L. opunticola, occurring on Opuntia in the Balearic Islands of Spain (Aguirre-Hudson \& Fiol 1993) and the lichenicolous L. haematommatum from New Zealand (Kalb et al. 1995), extending both the range and ecology of this genus. Leptorhaphis has typically been considered saprotrophic and non-lichen-forming (Vainio 1921, Swinscow 1965, Harris 1973, Aguirre \& Hawksworth 1987, Harris 1995), however, some species have been observed to form loose associations with algae (Swinscow 1965, Aguirre-Hudson 1991, 2009, Aguirre-Hudson \& Fiol 1993, Aguirre-Hudson et al. 2002), and one species is lichenicolous (Kalb et al. 1995). Harris (1995) has treated Leptorhaphis as part of Naetrocymbaceae, a placement Aguirre-Hudson et al. (2002) accepted. However, Harris (1995) noted that Leptorhaphis differed from the remaining Naetrocymbaceae genera in its hamathecium, ascus and presence of macroconidia. Consequently, it is unclear if this genus will be retained in Naetrocymbaceae and molecular data are needed.

In Index Fungorum (2018) the type species of Leptorhaphis is L. oxyspora, however, based on priority its correct name is L. epidermidisi. Aguirre-Hudson (1991) revised Leptorhaphis and examined a specimen in $\mathrm{H}$ named as Verrucaria oxyspora and determined it to be the holotype of $V$. oxyspora. We observed this specimen and designate it as the syntype of $L$. epidermidis.

Leptorhaphis epidermidis (Ach.) Th. Fr., Nova Acta R. Soc. Scient. upsal., Ser. 3 3: 373 (1861) [1860]

三Lichen epidermidis Ach. [as 'epidermis'], Lich. suec. prodr. (Linköping): 16 (1799) [1798]

= Leptorhaphis oxyspora (Nyl.) Körb., Syst. lich. germ. (Breslau): 371 (1855)

= Verrucaria oxyspora Nyl., Bot. Notiser: 179 (1852)

Index Fungorum number: IF393549; Facesoffungi number: FoF04651

Saprobic on dead unidentified plant. Thallus not observable. Sexual morph: Ascomata perithecial, 100-170 $\mu \mathrm{m}$ diam., 80-150 $\mu \mathrm{m}$ high, small, solitary, scattered, immersed becoming erumpent, finally superficial, globose to subglobose, top rounded, black to dark brown, membranous, ostiole not observed. Peridium 15-20 $\mu \mathrm{m}$ thick, composed of one layer of hyaline to brown cells of textura angularis. Hamathecium gelatinous, hyaline, septate, cellular and anastomosing pseudoparaphyses. Asci 40-55 × 10-15 $\mu \mathrm{m}(\bar{x}=58.7 \times 12.6, \mathrm{n}=20)$, 8-spored, bitunicate, clavate, with an ocular chamber. Ascospores 20-30 $\times 1.5-3 \mu \mathrm{m}(\bar{x}=25.4 \times 6.3, \mathrm{n}=20)$, 2-3-seriate, fusiform, hyaline, 1-septate, guttulate, smooth-walled, not constricted at the septum, gelatinous sheath not observed. Asexual morph: Undetermined.

Material examined - On dead unidentified plant, W. Nylander (H 7503, syntype).

Tomasellia A. Massal., Flora, Regensburg 39: 283 (1856)

Saprobic on smooth bark of trees and shrubs. Sexual morph: Ascostromata solitary to gregarious, immersed becoming erumpent, finally superficial, irregular, black to dark brown, 
membranous, multilocules. Locules immersed in ascomata, globose to subglobose, usually with flat base, each locule with a short, central ostiole. Peridium thin, composed of one layer of hyaline to brown cells of textura angularis to epidermoidea. Hamathecium gelatinous, comprising hyaline, septate, cellular pseudoparaphyses. Asci 8-spored, bitunicate, broad clavate to elongate-subglobose, with an ocular chamber, and occasionally with a short-pedicel. Ascospores elongate-ellipsoid, hyaline, 1-septate, smooth-walled, upper cell larger but lower cell longer, constricted at the septum, gelatinous sheath not observed. Asexual morph: Undetermined.

Type species - Tomasellia arthonioides (A. Massal.) A. Massal.
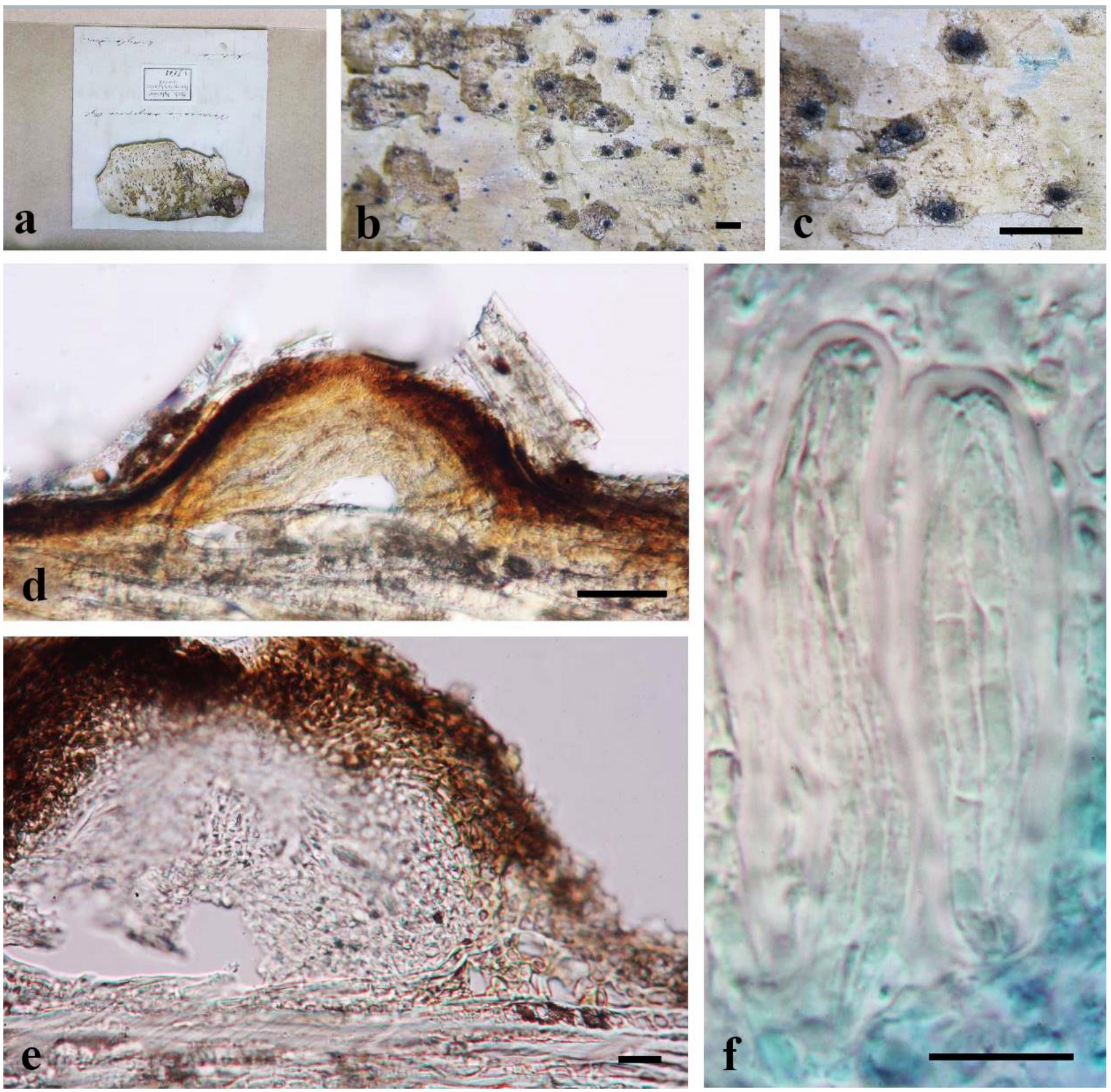

(

Figure 39 - Leptorhaphis epidermidis (H 7503, syntype). a Herbarium label and specimen. b, c Appearance of black ascomata on host surface. d Vertical section of ascoma. e Peridium. $\mathrm{f}, \mathrm{g}$ Asci with immature ascospores. Scale bars: $\mathrm{b}, \mathrm{c}=5 \mathrm{~mm}, \mathrm{~d}=100 \mu \mathrm{m}, \mathrm{e}, \mathrm{f}=10 \mu \mathrm{m}$.

Notes - Tomasellia has often been discussed with reference to Mycoporum; both form compound ascomata containing several locules, each producing their own ostiole (Harris 1995). The delimitation of these two genera has remained controversial. Harris (1995) transferred most species of Tomasellia to Mycoporum (Mycoporaceae) and suggested retaining five non-lichen- 
forming species in the genus Tomasellia. He distinguished these two genera based on ascus, ascospore, conidial and hamathecial characters. The generic delimitations of Harris (1995) have been accepted by some (Sanderson \& Coppins 2009a, b), while others (Aptroot 2002a, b) continue to employ a different circumscription of these genera. Tomasellia arthonioides is the type specie of Tomasellia, introduced by Massalongo (1856). Tomasellia arthonioides is characterized by its black ascomata contents and multi-locules. Such character is similar to those of Mycoporum (Harris 1995). However, they are separable by asci and ascospores features.

Tomasellia arthonioides (A. Massal.) A. Massal., Flora, Regensburg 39: 284 (1856) Fig. 40

三Arthopyrenia arthonioides A. Massal., Ric. auton. lich. crost. (Verona): 169 (1852)

Index Fungorum number: IF1124738; Facesoffungi number: FoF04652

Saprobic on the bark of Fraxinus ornus. Thallus not observable. Sexual morph: Ascostromata 0.4-1.3 mm long, $0.2-0.65 \mathrm{~mm}$ wide, $100-200 \mu \mathrm{m}$ high, solitary to gregarious, immersed becoming erumpent, finally superficial, irregular, black to dark brown, membranous, with 1-4 locules. Locules 100-200 × 130-150 $\mu \mathrm{m}$, immersed in ascomata, globose to subglobose, usually with flat base, each locule with a short, central ostiole. Peridium 3-5 $\mu \mathrm{m}$ thick, composed of one layer of hyaline to brown cells of textura angularis to epidermoidea. Hamathecium gelatinous, comprising hyaline, septate, cellular pseudoparaphyses, $2-3 \mu \mathrm{m}$ wide. Asci 40-48 $\times 10-17 \mu \mathrm{m}(\bar{x}$ $=45.4 \times 13.6, \mathrm{n}=20), 8$-spored, bitunicate, broad clavate to elongate-subglobose, with an ocular chamber, and occasionally with a short-pedicel. Ascospores $10-15 \times 3-4.5 \mu \mathrm{m}(\bar{x}=13.4 \times 3.8, \mathrm{n}=$ 20), 2-3-seriate to irregularly arranged in asci, elongate-ellipsoid, hyaline, 1-septate, smoothwalled, upper cell larger but lower cell longer, constricted at the septum, gelatinous sheath not observed. Asexual morph: Undetermined.

Material examined - ITALY, Trentino-Alto Adige Province, on the bark of Fraxinus ornus L. (Oleaceae), J. Milde (S-F217044).

Parmulariaceae E. Müll. \& Arx ex M.E. Barr, Mycologia 71(5): 944 (1979)

Members of Parmulariaceae are obligate biotrophic, plant-parasitic fungi which develop on the surface of living plants (Guatimosim et al. 2015, Tian et al. 2016). Many studies have described and illustrated the genera in Parmulariaceae (Inácio et al. 2012, Hyde et al. 2013, Guatimosim et al. 2014, Tian et al. 2016). A key to genera of Parmulariaceae was provided in Hyde et al. (2013). Guatimosim et al. (2015) provided molecular phylogenetic studies of the Parmulariaceae. We transfer Syrropeltis to Parmulariaceae based on its morphology.

Syrropeltis Bat., J.L. Bezerra \& Matta, in Batista \& Bezerra, Portug. acta biol., Sér. B 7(4): 376 (1964)

Epiphytes on surface of leaves appearing as large black spots. Superficial mycelium absent. Sexual morph: Ascostromata superficial on surface of host, solitary, circular, flattened, swollen and cracked around the center, black. Locules central ostiole, walled cells arranged radially when viewed in squash mounts. Hamathecium hyaline, aseptate, embedded in a gelatinous matrix. Peridium very thin, comprising dark brown to black cells of textura angularis,. Asci 8-spored, bitunicate, cylindrical to obovoid, with an ocular chamber, short and round pedicel. Ascospores 2seriate, 1-septate, oval to ellipsoid, upper cell broader than lower cell, slightly constricted and darker at the septum, smooth-walled, hyaline when immature, pale brown at maturity. Asexual morph: Undetermined.

Type species - Syrropeltis xylopia Bat., J.L. Bezerra \& Matta

Notes - Syrropeltis was introduced in Batista \& Bezerra (1964), and it is a monotypic genus. MycoBank (2018) listed Syrropeltis in Dothideales, but the genus was listed as genera incertae sedis in Dothideomycetes by Wijayawardene et al. (2014, 2018) and Index Fungorum (2018). Stromata appear as a black circle on surface of leaves. No sequence data is available for Syrropeltis xylopia. We place Syrropeltis within Parmulariaceae based on its large and black ascostromata on 
host substrate and 1-septate ascospores that are ovoid with upper cell broader and longer, slightly constricted and pale brown to brown at the septum.
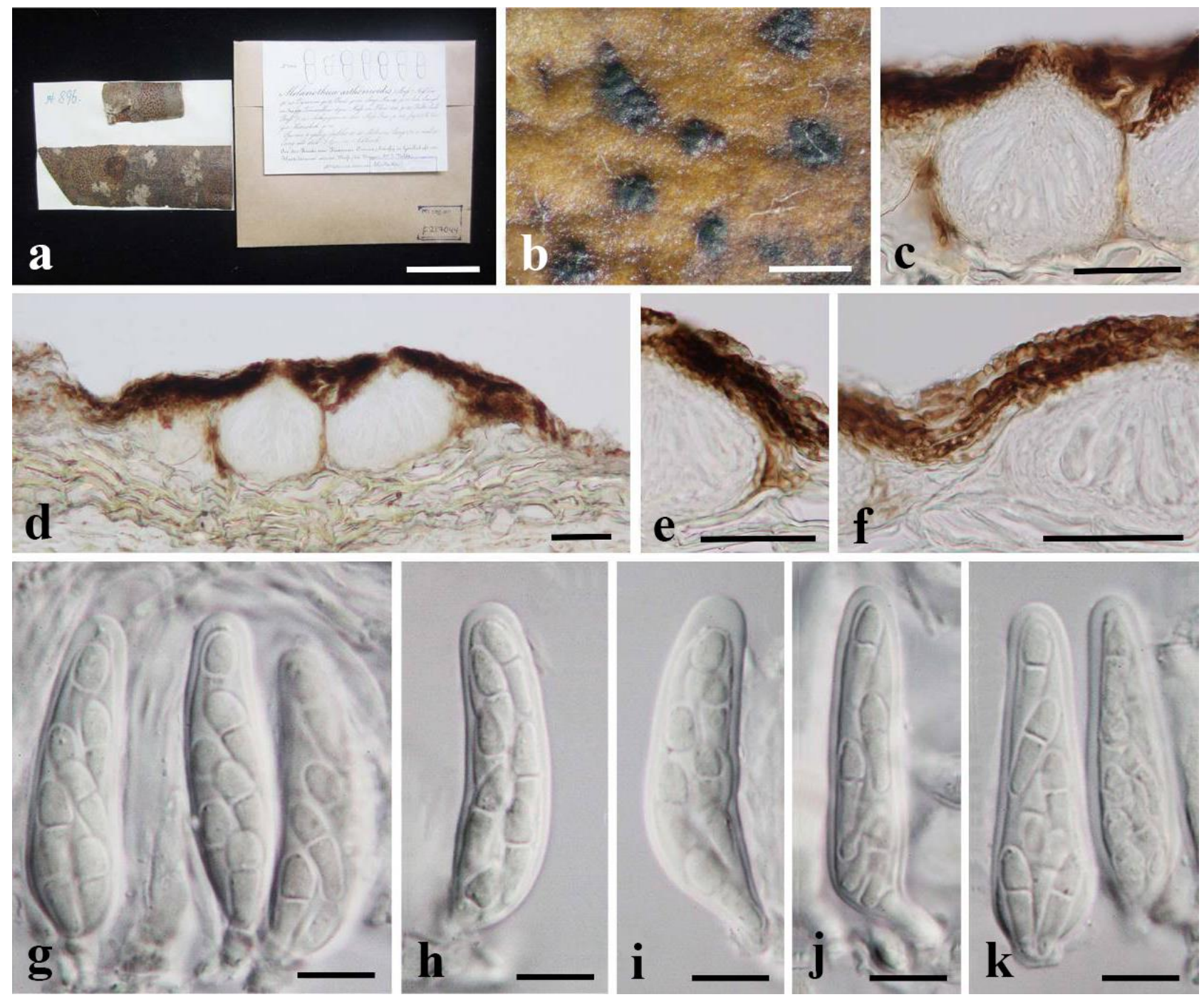

Figure 40 - Tomasellia arthonioides (S-F217044). a Herbarium label and specimen. b Black stromata on the host. c, d Vertical section of an ascostroma. e, f Peridium. g-k Asci with ascospores. Scale bars: $\mathrm{a}=50 \mathrm{~mm}, \mathrm{~b}=500 \mu \mathrm{m}, \mathrm{c}-\mathrm{f}=50 \mu \mathrm{m}, \mathrm{g}-\mathrm{k}=10 \mu \mathrm{m}$.

Syrropeltis xylopia Bat., J.L. Bezerra \& Matta, in Batista \& Bezerra, Portug. acta biol., Sér. B 7(4): 377 (1964)

Fig. 41

Index Fungorum number: IF311399; Facesoffungi number: FoF04653

Epiphytes on surface of leaves appearing as large black spots. Superficial mycelium absent. Sexual morph: Ascostromata up to $2000 \mu \mathrm{m}$ diam., superficial on surface of host, solitary, circular, flattened, swollen and cracked around the center, black. Locules up to $120 \mu \mathrm{m}$, with central ostiole, cells arranged radially when viewed in squash mounts. Hamathecium $1 \mu \mathrm{m}$, hyaline, aseptate, embedded in a gelatinous matrix. Peridium very thin, comprising dark brown to black cells of textura angularis. Asci 30-36 $\times 8-10 \mu \mathrm{m},(\bar{x}=33 \times 9 \mu \mathrm{m}, \mathrm{n}=10)$, 8-spored, bitunicate, cylindrical to obovoid, with an ocular chamber, with short and round pedicel. Ascospores $8-10 \times$ 3-4 $\mu \mathrm{m}(\bar{x}=9 \times 3.5 \mu \mathrm{m}, \mathrm{n}=20)$, 2-seriate, 1-septate, oval to ellipsoid, upper cell broader than lower cell, slightly constricted and darker at the septum, smooth-walled, hyaline when immature, pale brown at maturity. Asexual morph: Undetermined.

Material examined - BRAZIL, Bahia, Ituberà, on leaves of Xylopia emarginata Mart. (Annonaceae), 21 August 1961, E.A. Matta \& R. Pereira (URM 39757, holotype). 


\section{Dothideomycetes, genera incertae sedis}

We examined the type specimens of Epibelonium gaeumannii, Otthia spiraeae and Phycorella scytonematis. All of these are of uncertain taxonomic placement as they are not typical of any existing families of Dothideomycetes.
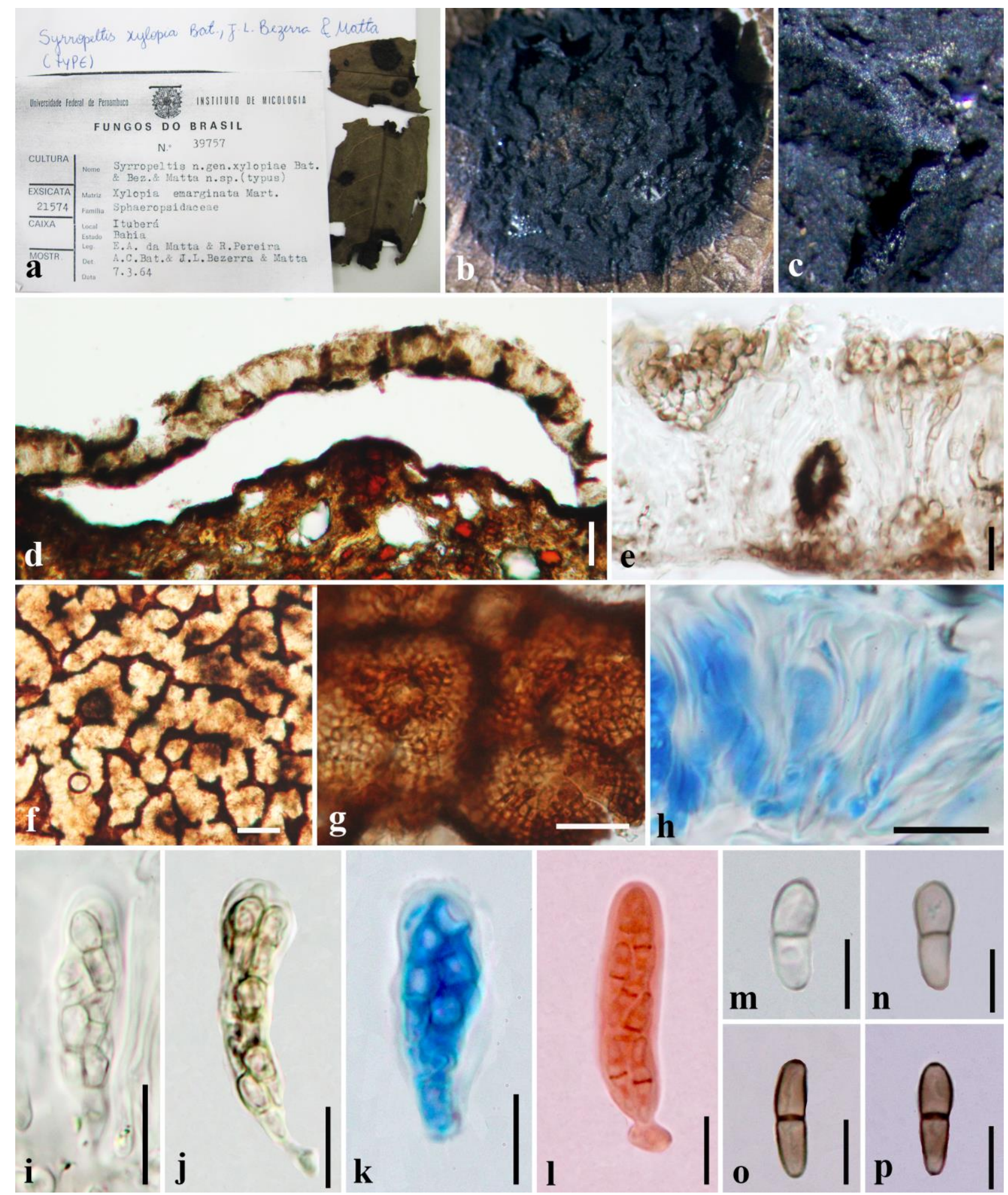

Figure 41 - Syrropeltis xylopia (URM 39757, holotype). a Herbarium label and specimen. b, c Ascostromata on substrate. d, e Vertical section through ascostromata. f Ascostromata when viewed in squash mounts. g Peridium structure seen from above. $\mathrm{h}$ Asci embedded in pseudoparaphyses. $\mathrm{i}$ Ascus. $\mathrm{j}$ Ascus in Melzer's reagent. $\mathrm{k}$ Ascus in lactophenol cotton blue reagent. 1 Ascus in Congo red reagent. $\mathrm{m}, \mathrm{n}$ Immature ascospores. o, p Mature ascospores. Scale bars: $\mathrm{d}, \mathrm{f}, \mathrm{g}=50 \mu \mathrm{m}, \mathrm{e}, \mathrm{h}=$ $10 \mu \mathrm{m}, \mathrm{i}-\mathrm{l}=10 \mu \mathrm{m}, \mathrm{m}-\mathrm{p}=5 \mu \mathrm{m}$. 
Epibelonium E. Müll., Phytopath. Z. 47: 240 (1963)

Epiphytic on dead leaves of Quercus ilex. Sexual morph: Apothecia superficial, stalked, globose, reddish brown to dark brown, becoming black, scattered, solitary on upper surface of leaves, quadrilateral. Exciple angularis, brown to reddish brown. Asci 4-spored, bitunicate, clavate, cylindro-clavate, hyaline, apically rounded, with an ocular chamber, short-pedicellate. Hamathecium comprising numerous, filiform, 1.3-3.5 $\mu \mathrm{m}$ wide, hyaline, septate, hypha-like, straight or flexuous pseudoparaphyses, swollen and rounded at the base. Ascospores ellipsoid, hyaline, with transverse septa only, slightly constricted at the septa, smooth-walled. Asexual morph: Undetermined.

Type species - Epibelonium gaeumannii E. Müll.

Notes - Epibelonium was introduced by Müller (1963) as a genus in Schizothyriaceae with Epibelonium gaeumannii as the type species. Subsequently, the genus has been transferred to Saccardiaceae based on the ascomata that are apothecia-like, small, and borne on superficial mycelium (von Arx \& Müller 1975). The genus is monotypic according to Index Fungorum (2018).

The major morphological characters of this genus are cupulate, stipitate apothecia and cylindric-clavate asci, with an ocular chamber. These characters do not match with the family limitation for Saccardiaceae. We suggest the genus may belong to Patellariaceae, but we place it in Dothideomycetes genera, incertae sedis. Fresh specimens with asexual morph link and sequence data are required to provide exact placement for this genus.

Epibelonium gaeumannii E. Müll. [as 'gaeumanni'], Phytopath. Z. 47: 240 (1963)

Fig. 42

Index Fungorum number: IF330639; Facesoffungi number: FoF04654

Epiphytic on dead leaves of Quercus ilex. Sexual morph: Apothecia 150-230 × 75-100 $\mu \mathrm{m}$ (Müller 1963), superficial, cupulate, globose, reddish brown to dark brown becoming black, scattered, solitary on upper surface of leaves, quadrilateral. Exciple angularis, brown to reddish brown. Hamathecium 1-2.5 $\mu \mathrm{m}$ wide at the middle, $1.3-3.5 \mu \mathrm{m}$ wide at the base, 3-6-septate, filiform, swollen and rounded at the base, apices swollen glued together with gelatinized material to form pseudoepithecim, hyaline, septate, hypha-like, numerous, straight or flexuous. Asci 37-55 $\times$ 8-12 $\mu \mathrm{m}(\bar{x}=45 \times 10 \mu \mathrm{m}, \mathrm{n}=20), 4$-spored, bitunicate, clavate, cylindro-clavate, hyaline, apically rounded, with an ocular chamber, short-pedicellate. Ascospores 9-13 $\times 3-5 \mu \mathrm{m}(\bar{x}=11 \times 4 \mu \mathrm{m}, \mathrm{n}=$ 20), ellipsoid, hyaline, 1-3-septate, slightly constricted at the septa, smooth-walled. Asexual morph: Undetermined.

Material examined - FRANCE, Dept. Vaucluse, Mountain Ventoux, North side, on the road about 1000 m, on dead leaves of Quercus ilex L. (Fagaceae), 23 May 1962, E. Müller (ZT Myc 4388 , holotype).

Otthia Nitschke ex Fuckel, Jb. nassau. Ver. Naturk. 23-24: 169 (1870) [1869-70]

Saprobic on dry twigs of Spiraea. Sexual morph: Ascostromata pseudothecia, immersed, or erumpent through bark fissures, gregarious to densely crowded, dark to black, short-stalked, globose or subglobose, with or without an ostiole. Ostiole central, short, slightly sunken, inconspicuous at the surface, reddish brown to dark brown. Peridium composed of cells of textura angularis. Hamathecium comprising numerous, filiform, hyaline, septate, hypha-like pseudoparaphyses. Asci 8-spored, bitunicate, cylindrical, with rounded apex, short-pedicellate, arising from the ascoma base. Ascospores overlapping, initially hyaline, ellipsoid, becoming dark brown, ovoid to broadly ellipsoidal, 1-septate, slightly constricted at the septum, smooth-walled. Asexual morph: Undetermined.

Type species - Otthia spiraeae (Fuckel) Fuckel

Notes - Otthia was placed in the Cucurbitariaceae, Pleosporales (Winter 1885, Barr 1979). Phillips et al. (2005) examined O. spiraeae (IMI 63581b) and confirmed that morphology of this specimen did not match that of Otthia but had greater affinity to Botryosphaeria; they therefore applied the name Botryosphaeria sarmentorum based on morphological and phylogenetical studies. This species is now regarded as Dothiorella sarmentorum (IMI 63581b) (Phillips et al. 2013). 
Phillips et al. (2005) also examined O. spiraeae (K 104853, Fuckel, Fungi Rhenani No. 975). We examined the holotype specimen of Cucurbitaria spiraeae Fuckel (F88441) and found that it to be similar to K 104853 as described in Phillips et al. (2005). It has cylindrical, bitunicate asci with thin endotunica, 1-seriate, brown, 1-septate, oval ascospores with both ends rounded, and narrow, infrequently septate pseudoparaphyses. Kirk et al. (2008) listed Otthia in Botryosphaeriaceae while Lumbsch \& Huhndorf (2010) and Wijayawardene et al. (2018) placed it in Dothideomycetes genera incertae sedis. $\mathrm{Hu}$ (2010) described and identified isolate HKUCC10896 as O. spiraeae with illustrations and placed this isolate in Botryosphaeriaceae on the basis of sequences data from both LSU and SSU, which clustered it with other Botryosphaeriaceae species.
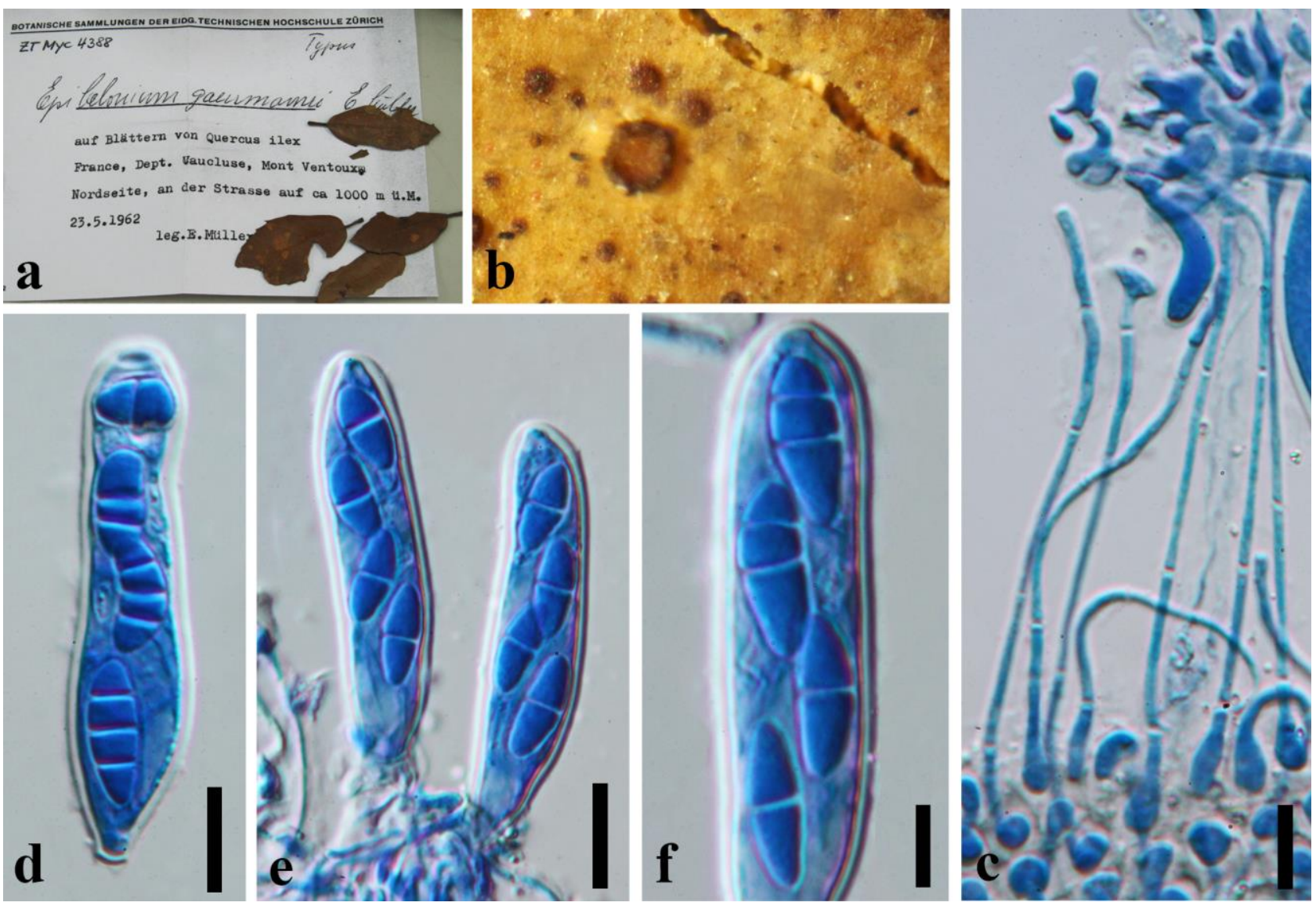

Figure 42 - Epibelonium gaeumannii (ZT Myc 4388, holotype). a Material label and specimen. b Apothecia on leaf. c Pseudoparaphyses. d-f Asci with ascospores. Note: c-f stained in lactophenol cotton blue. Scale bars: $\mathrm{c}=20 \mu \mathrm{m}, \mathrm{d}, \mathrm{e}=10 \mu \mathrm{m}, \mathrm{f}=5 \mu \mathrm{m}$.

However, Otthia, as typified by $O$. spiraeae, is morphologically distinct from Botryosphaeria in having asci that are cylindrical with a thin endotunica, while in Botryosphaeria the asci are clavate with a thick endotunica. Pseudoparaphyses in Otthia are narrow and sinuous, infrequently septate and not constricted at the septa, as compared to the broader, frequently septate ones in Botryosphaeria (Phillips et al. 2005). Otthia is characterized by globose to subglobose ascomata, cylindrical asci, and 1-septate ascospores, constricted at septum, mostly wider above septum, ellipsoidal with rounded ends. Otthia somewhat resembles Cucurbitaria in Cucurbitariaceae (Doilom et al. 2013) in having ascomata that are immersed to erumpent through bark fissures on host substrates and cylindrical asci, but it differs in ascomata lacking a basal pseudostroma as seen in Cucurbitaria. Furthermore, ascospores in Otthia are 1-septate, while in Cucurbitaria ascospores are muriform. Otthia is similar to genera placed in Didymosphaeriaceae, however, we place it in Dothideomycetes, genera incertae sedis pending studies with molecular data. 
Otthia spiraeae (Fuckel) Fuckel, Jb. nassau. Ver. Naturk. 23-24: 170 (1870) [1869-70]

Fig. 43

$\equiv$ Cucurbitaria spiraearum Fuckel, Fungi rhenani exsic., fasc. 10: no. 975 (1864)

Index Fungorum number: IF166179; Facesoffungi number: FoF04655

Saprobic on dry twigs of Spiraea opulifoliae. Sexual morph: Ascostromata (180-)305-330(440) $\mu \mathrm{m}$ high $\times(260-) 355-420(-500) \mu \mathrm{m}$ diam. $(\bar{x}=290 \times 360 \mu \mathrm{m}, \mathrm{n}=30)$, pseudothecia, immersed, or erumpent through bark fissures, gregarious to densely crowded, dark to black, globose or subglobose, with or without an ostiole. Ostiole 180-300 $\mu \mathrm{m}$ high, 170-210 $\mu \mathrm{m}$ wide, central, short, slightly sunken, inconspicuous at the surface, reddish brown to dark brown. Peridium 55-105 $\mu \mathrm{m}$ thick at the sides, composed of cells of textura angularis, comprising two layers, outer
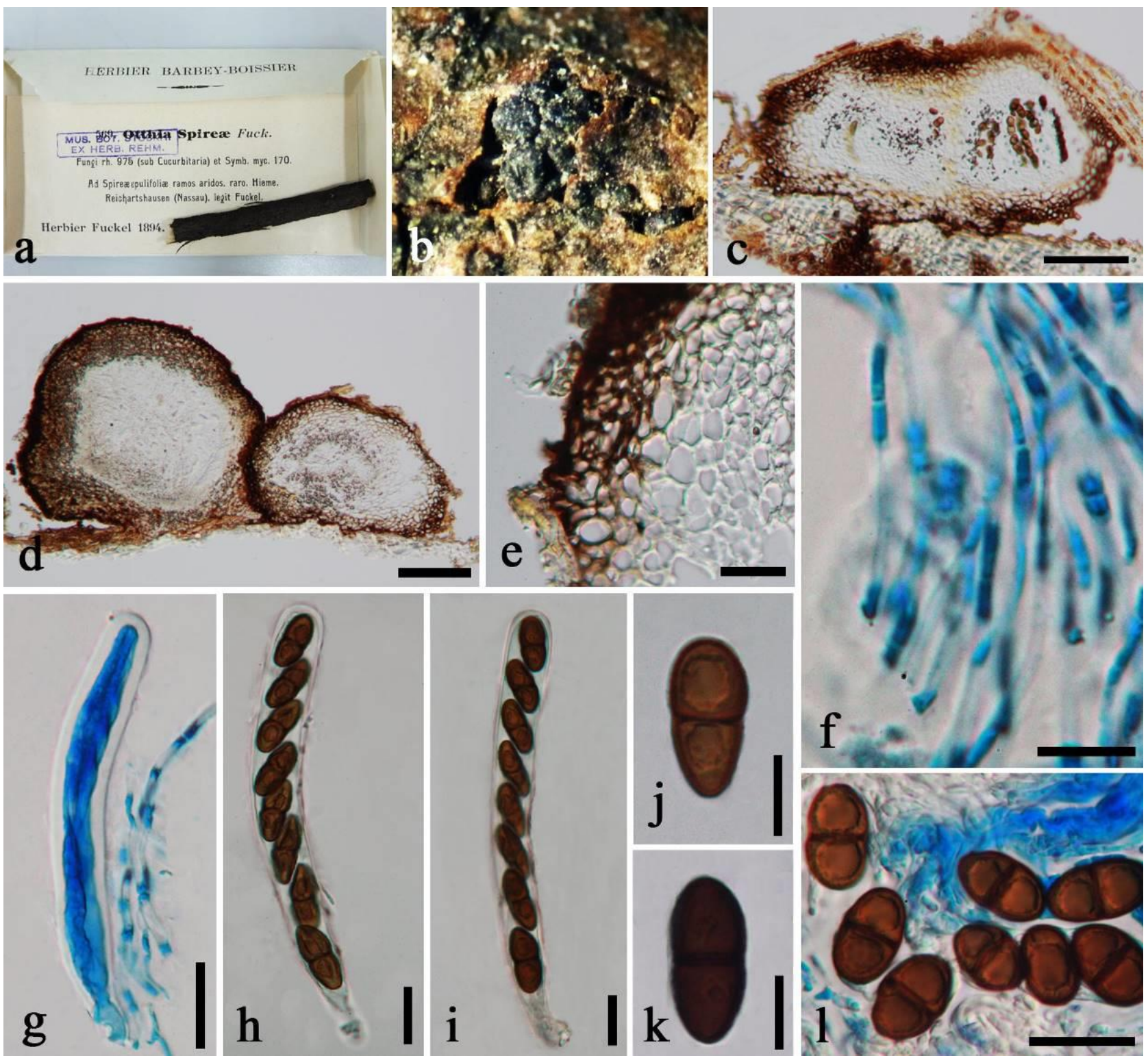

Figure 43 - Otthia spiraeae (S-F88441, holotype). a Material label and specimen. b Ascostromata on host. c, d Vertical section through ascostromata. e Peridium. f Pseudoparaphyses. g-i Asci. $\mathrm{j}-1$ Ascospores. Note: $\mathrm{f}, \mathrm{g}, 1$ stained in lactophenol cotton blue. Scale bars: $\mathrm{c}, \mathrm{d}=100 \mu \mathrm{m}, \mathrm{e}, \mathrm{g}-\mathrm{i}, \mathrm{l}=$ $20 \mu \mathrm{m}, \mathrm{f}, \mathrm{j}, \mathrm{k}=10 \mu \mathrm{m}$.

layer black, thick-walled, inner layer comprising 5-8 cell layers, light brown, reddish brown to hyaline, walled cells of textura angularis. Hamathecium comprising numerous, 2.5-4 $\mu \mathrm{m}$ wide, filiform, hyaline, septate, hypha-like, pseudoparaphyses. Asci $(140-) 160-170(-175) \times(15-) 17-$ $19(-20) \mu \mathrm{m}(\bar{x}=160 \times 17 \mu \mathrm{m}, \mathrm{n}=30), 8$-spored, bitunicate, cylindrical, rounded apex, short- 
pedicellate, arising from the ascoma base. Ascospores $(15-) 20-21(-24) \times 10-15 \mu \mathrm{m}(\bar{x}=20 \times 12$ $\mu \mathrm{m}, \mathrm{n}=30$ ), overlapping 1-seriate, initially hyaline, becoming dark brown, ellipsoid, ovoid to broadly ellipsoidal, 1-septate, slightly constricted at the septum, smooth-walled, guttulate. Asexual morph: Undetermined.

Material examined - GERMANY, Hessen, Reichartshausen (Nassau), on dry twigs of Spiraea opulifolia L. (Rosaceae), collection date unknown, Fuckel (S-F88441, holotype).

Phycorella Döbbeler, Sydowia 33: 33 (1980)

Biotrophic on Scytonema, infects single cells by haustoria. Sexual morph: Ascomata solitary or scattered among or sitting on algal filaments, sphaerical or slightly longer than wide, colorless. Peridium comprised of nearly isodiametric or slightly irregular cells. Ostiole not prominent. Paraphyses absent. Asci 8-spored to few, ellipsoidal to cylindrical, bitunicate, with a broadly rounded end and a short, broad pedicel. Ascospores overlapping irregularly arranged, ellipsoidal, hyaline, 2-celled, and smooth-walled. Hyphae colorless, branched, irregularly extending between the filaments of the alga. Appressoria roundish in outline, sitting sideways or stalked, rarely intercalary, not always distinct from the mycelium. Haustoria globose, usually individually inside the host cells. Asexual morph: Undetermined.

Type species - Phycorella scytonematis Döbbeler

Notes - The monotypic genus Phycorella was established by Döbbeler (1980) in Dothideales with $P$. scytonematis as the type species. Lumbsch \& Huhndorf (2010) accommodated Phycorella in Dothideomycetes, genera incertae sedis. Unfortunately, the taxonomic position of $P$. scytonematis remains unresolved as no sequence data is available.

Phycorella scytonematis Döbbeler, Sydowia 33: 33 (1980)

Fig. 44

Index Fungorum number: IF116011; Facesoffungi number: FoF04656

Biotrophic on Scytonema, infects single cells of Scytonema by haustoria. Sexual morph: Ascomata solitary or scattered among or sitting on algal filaments, sphaerical or slightly longer than wide, colorless. Peridium 3-6 $\mu \mathrm{m}$ thick, comprised of nearly isodiametric or slightly irregular cells. Ostiole not prominent. Paraphyses absent. Asci 8-spored to few, ellipsoidal to cylindrical, bitunicate, with a broadly rounded end and a short, broad pedicel. Ascospores overlapping irregularly arranged, ellipsoidal, hyaline, 2-celled, smooth-walled. Hyphae colorless, branched, irregularly extending between the filaments of the alga. Appressoria roundish in outline, sitting sideways or stalked, rarely intercalary, not always distinct from the mycelium. Haustoria globose, usually individually inside the host cells. Asexual morph: Undetermined.

Material examined - AUSTRALIA, Sydney, on Scytonema sp. (Cyanophyceae), collected before 1877 by an unknown niece KAYSER'S name (M- holotype).

Sordariomycetes O.E. Erikss. \& Winka, Myconet 1(1): 10 (1997)

Amphisphaeriales, genera incertae sedis

Fasciatispora K.D. Hyde, Trans. Mycol. Soc. Japan 32(2): 265 (1991)

Saprobic on dead leaflet, frond and leaves. Sexual morph: Ascomata immersed to semiimmersed beneath a thin stroma, black, raised, solitary, in cross section globose, subglobose, irregular, with central ostiole. Peridium outwardly comprising thick-walled, compressed, dark brown cells of textura angularis. Paraphyses hyaline, filamentous, cylindrical, septate, branched. Asci 8-spored, unitunicate, cylindrical, short-pedicellate, apically rounded, with a $\mathrm{J}+$, subapical ring. Ascospores unicellular, hyaline, olivaceous-brown to brown when mature, young ascospores fusiform becoming reniform to ellipsoidal at maturity, guttulate, smooth-walled, with a central pallid band, surrounded by a thick mucilaginous sheath. Asexual morph: Undetermined.

Type species - Fasciatispora nypae K.D. Hyde

Notes - Hyde (1991) introduced Fasciatispora and typified by $F$. nypae K.D. Hyde. We introduce a new species, Fasciatispora arengae based on morphology and place it within subclass Xylariomycetidae, families incertae sedis. 


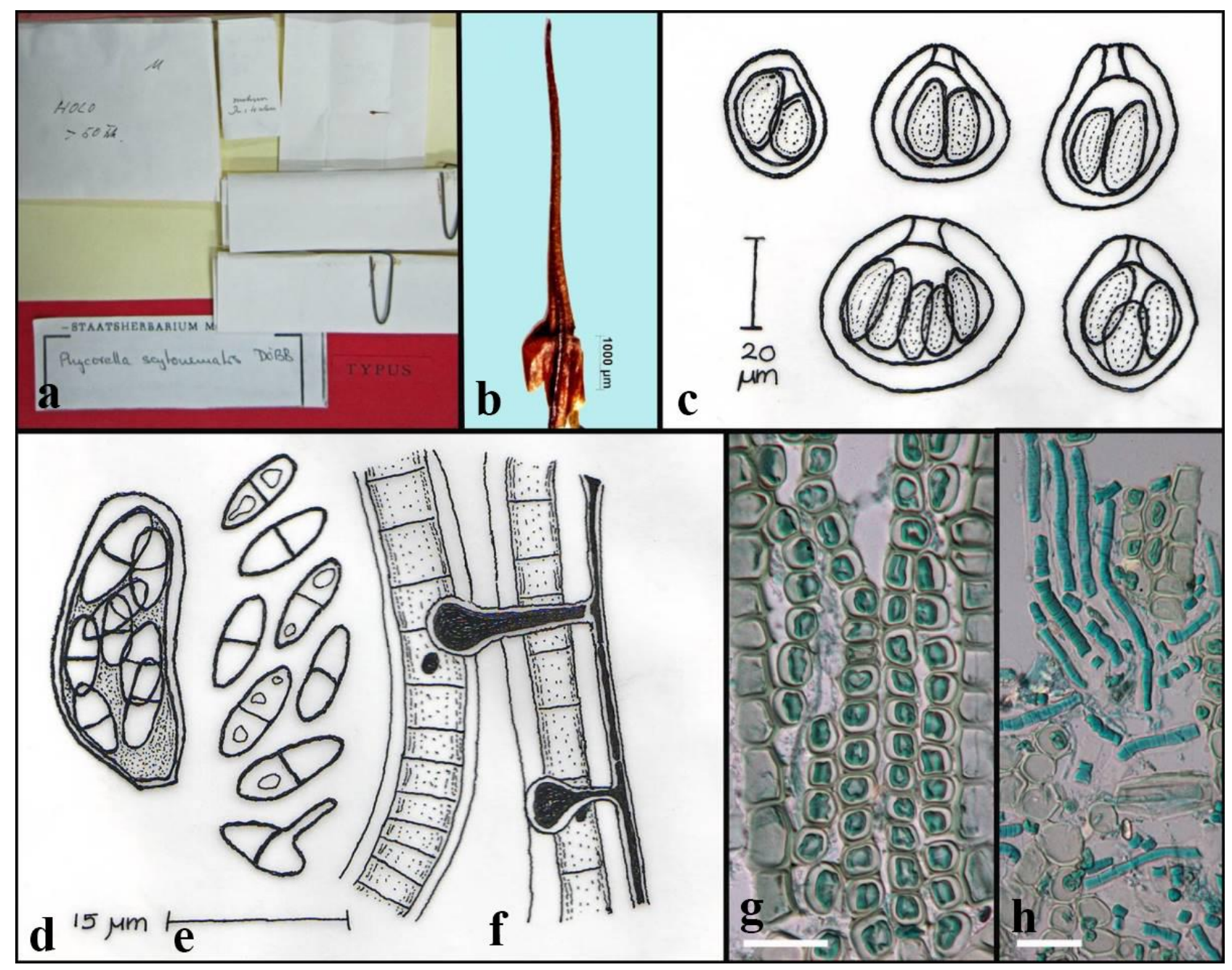

Figure 44 - Phycorella scytonematis (M- holotype). a, b Herbarium label and specimen. c Vertical section of ascomata. d Ascus with 8-ascospores. e Ascospores. $\mathrm{f}-\mathrm{h}$ Infected Scytonema filaments and the haustoria inside the host cells. (c-f redrawn from the original type species drawing, Döbbeler (1980)). Scale bars: $b=1000 \mu \mathrm{m}, \mathrm{c}=20 \mu \mathrm{m}, \mathrm{d}-\mathrm{f}=15 \mu \mathrm{m}, \mathrm{g}, \mathrm{h}=25 \mu \mathrm{m}$.

Fasciatispora arengae Konta \& K. D. Hyde, sp. nov.

Fig. 45

Index Fungorum number: IF554299; Facesoffungi number: FoF04373

Etymology: refers to the host genus name (Arenga)

Saprobic on dead leaflet of Arenga pinnata. Sexual morph: Ascomata 147-333 $\mu$ m diam. $\times$ 142-135 high $\mu \mathrm{m}(\bar{x}=240 \times 171 \mu \mathrm{m}, \mathrm{n}=10)$, semi-immersed, visible as black, raised, solitary, in cross section globose, subglobose, lenticular, irregular, with central ostiole. Ostiole 42-60 $\mu \mathrm{m}$ diam. at the base $\times 34-52 \mu \mathrm{m}$ high $(\bar{x}=52 \times 44 \mu \mathrm{m}, \mathrm{n}=5)$. Peridium 20-25 $\mu \mathrm{m}$ diam. $(\bar{x}=23$ $\mu \mathrm{m}, \mathrm{n}=10$ ), outwardly comprising thick-walled, compressed, dark brown cells of textura angularis. Paraphyses $1.8-3 \mu \mathrm{m}$ diam. $(\bar{x}=2.4 \mu \mathrm{m}, \mathrm{n}=10)$, hyaline, filamentous, cylindrical, septate, branched. Asci 80-130 × 8-11 $\mu \mathrm{m}(\bar{x}=117 \times 9 \mu \mathrm{m}, \mathrm{n}=20), 8$-spored, unitunicate, cylindrical, short-pedicellate, apically rounded, with a $\mathrm{J}+$, subapical ring. Ascospores 12-16 $\times 6-8$ $\mu \mathrm{m}(\bar{x}=14 \times 7 \mu \mathrm{m}, \mathrm{n}=20)$, uniseriate, hyaline, brown when mature, young ascospore fusiform becoming ellipsoidal at maturity, unicellular, guttulate, smooth-walled, with a central pallid band, surrounded by a thick mucilaginous sheath, lacking germ slit. Asexual morph: Undetermined.

Material examined - THAILAND, Phang-nga Province, on dead leaflet of Arenga pinnata (Wurmb) Merr. (Arecaceae), 5 December 2014, S. Konta, PHR07g (MFLU 15-0301, holotype).

Notes - Fasciatispora arengae is similar to species in genus Fasciatispora in having uniseriate, cylindrical asci, with a $\mathbf{J}+$, subapical ring and unicellular ascospores with a central pallid band, but is distinct in its semi-immersed ascomata and ascospore dimensions. Ascospore 

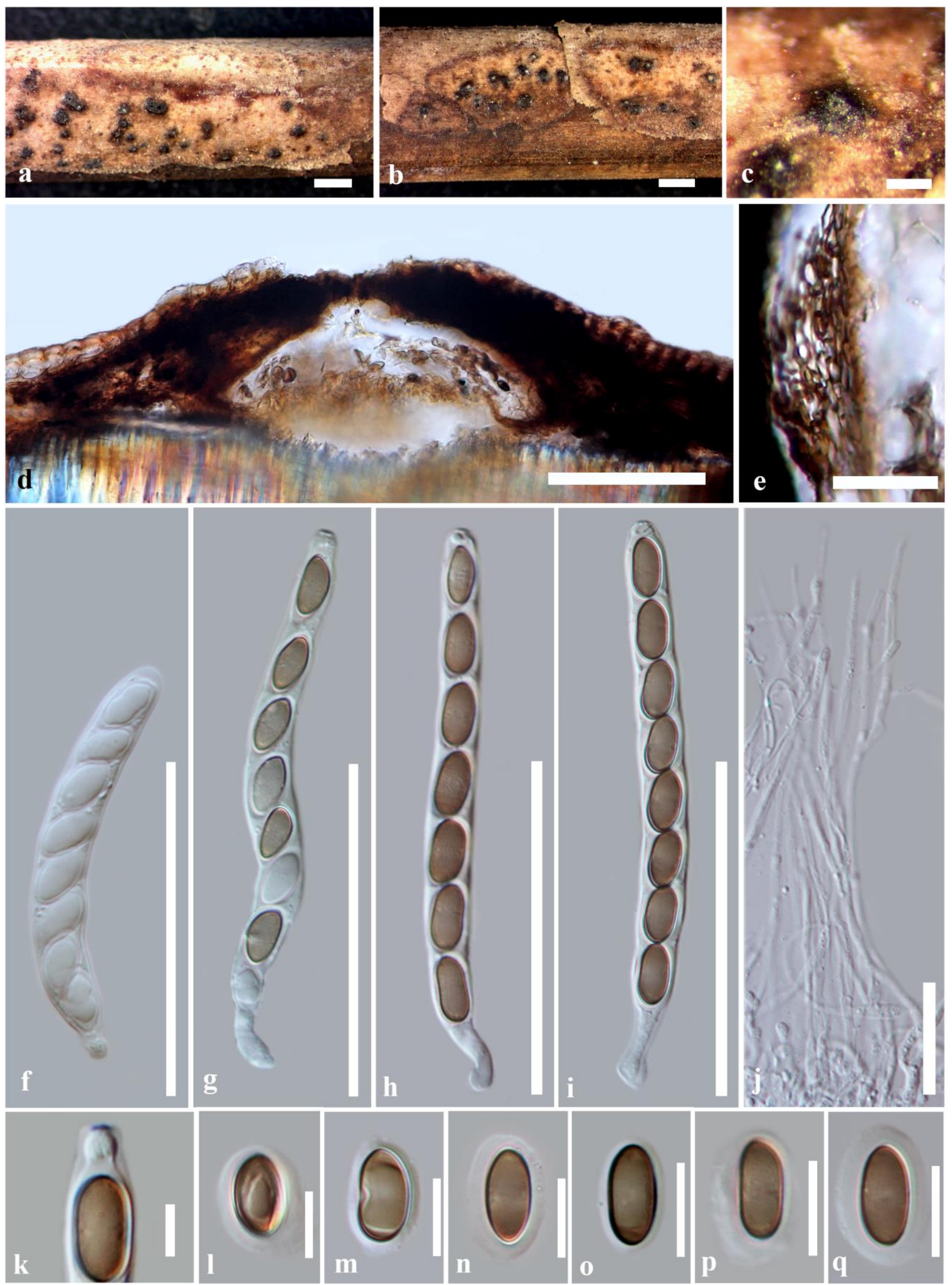

Figure 45 - Fasciatispora arengae (MFLU 15-0301, holotype). a, b Appearance of ascomata on host substrate. c Close up of ascomata. d Vertical section of ascoma. e Peridium. $f-i$ Asci. $j$ Paraphyses. $\mathrm{k} \mathrm{J}+$ reaction with Melzer's reagent in apical ring. $1-\mathrm{q}$ Ascospores. Scale bars: $\mathrm{a}, \mathrm{b}=$ $1000 \mu \mathrm{m}, \mathrm{c}=200 \mu \mathrm{m}, \mathrm{d}=100 \mu \mathrm{m}, \mathrm{e}, \mathrm{j}=20 \mu \mathrm{m}, \mathrm{f}-\mathrm{i}=50 \mu \mathrm{m}, \mathrm{k}-\mathrm{q}=10 \mu \mathrm{m}$. 
dimensions of $F$. arengae $(12-16 \times 6-8 \mu \mathrm{m})$ are slightly similar to $F$. nypae $(11.6-17 \times 5.6-7.1$ $\mu \mathrm{m})$, but $F$. arengae is collected from dead leaflet of Arenga pinnata, while $F$. nypae is reported as a marine inhabitant (Hyde 1991). Fasciatispora arengae has larger ascospores than F. calami (12$13 \times 5-6 \mu \mathrm{m})$ and $F$. lignicola $(8.4-14.9 \times 3.9-7.5 \mu \mathrm{m})$.

\section{Diaporthomycetidae, family incertae sedis}

Barbatosphaeriaceae H. Zhang, K.D. Hyde \& Maharachch.

The family Barbatosphaeriaceae, in Diaporthomycetidae, families incertae sedis was introduced to accommodate three genera Barbatosphaeria, Xylomelasma and Ceratostomella (Zhang et al. 2017). Those genera were previously maintained in Sordariomycetidae, genera incertae sedis (Maharachchikumbura et al. 2016). The family is typified by genus Barbatosphaeria Réblová. Members of the family are characterized by dark, long-necked, astromatic ascomata, which are mostly surrounded by sparse mycelium or pubescence, clavate or cylindrical-clavate asci arising from ascogenous hyphae and mostly with ellipsoidal ascospores (Réblová 2007, Zhang et al. 2017).

\section{Barbatosphaeria Réblová, Mycologia 99(5): 727 (2008) [2007]}

Saprobic on decayed wood, branches and bark. Sexual morph: Ascomata non-stromatic, arranged in circular groups, slightly flattened, globose to subglobose, dark brown to black. Neck forming laterally, cylindrical, slightly flexuous, rounded-truncate at the apex. Peridium outer layer with dark brown to black, inner layer hyaline, thin-walled, compost of textura prismatica. Paraphyses septate, slightly constricted at the septa, tapering towards the tip, wider near the base, longer than the asci. Asci 8-spored, unitunicate, cylindrical-clavate. Ascospores 1-septate, ellipsoidal, hyaline, smooth-walled. Asexual morph: Ramichloridium-like and Sporothrix-like (Réblová 2007).

Type species - Barbatosphaeria barbirostris (Dufour) Réblová

Notes - The genus Barbatosphaeria was described for Calosphaeria barbirostris occurring on decayed wood beneath the periderm (Réblová 2007). There are eight species described based on molecular data (Réblová 2007, Réblová \& Stepanek 2009, Réblová et al. 2015). This genus was accommodated in Sordariomycetes incertae sedis based on SSU sequences (Réblová 2007), and later by multigene phylogenetic analysis of the SSU, LSU and RPB2 sequences (Réblová et al. 2015). Ascomata are astromatic perithecia with a long neck, and ascospores usually group in the middle of the sporiferous part of ascus, forming an empty apex. The asexual morph of Barbatosphaeria is Ramichloridium-like and Sporothrix-like.

Barbatosphaeria hippocrepida (Réblová) Réblová, Persoonia 35: 32 (2015)

Fig. 46

$\equiv$ Tectonidula hippocrepida Réblová, Mycol. Res. 113(9): 998 (2009)

Index Fungorum number: IF810130; Facesoffungi number: FoF04658

Saprobic on decayed wood of branch of Nothofagus sp. Sexual morph: Ascomata 326-500 $\mu \mathrm{m}$ high, $\times 370-550 \mu \mathrm{m}$ diam., growing on decayed wood beneath the peridium, astromatic, arrange in circular groups of 5-11, slightly flattened, globose to subglobose, dark brown to black. Neck 310-870 $\mu \mathrm{m}$ long, 100-115 $\mu \mathrm{m}$ wide, forming laterally, cylindrical, slightly flexuous, rounded to truncate at the apex. Peridium 30-50 $\mu \mathrm{m}$ wide, 3-layered, external layer with dark brown to black, opaque cells, middle layer composed of 10-15 cells of brown polyhedral textura prismatica or textura globulosa, inner layer composed of 3-5 cells of hyaline, thin-walled, elongated textura prismatica. Paraphyses $2.2-5.3 \mu \mathrm{m}$ wide, septate, slightly constricted at the septa, tapering towards the apex, wider near the base, longer than the asci. Asci $17-20 \times 3-5 \mu \mathrm{m}(\bar{x}$ $=18 \times 4 \mu \mathrm{m})$, unitunicate, cylindrical-clavate, with truncate apex, short stipe, mature asci with a septum near the bottom. Ascospores 2.8-4.6 $\times 0.65-0.83 \mu \mathrm{m}(\bar{x}=3 \times 0.7 \mu \mathrm{m})$ diam., 1-celled, Uto horseshoe-shaped or 3/4 circular, allantoid, aseptate, hyaline, smooth-walled, arranged as a group in the middle of the ascus. Asexual morph: Sporothrix-like (Réblová et al. 2015). 


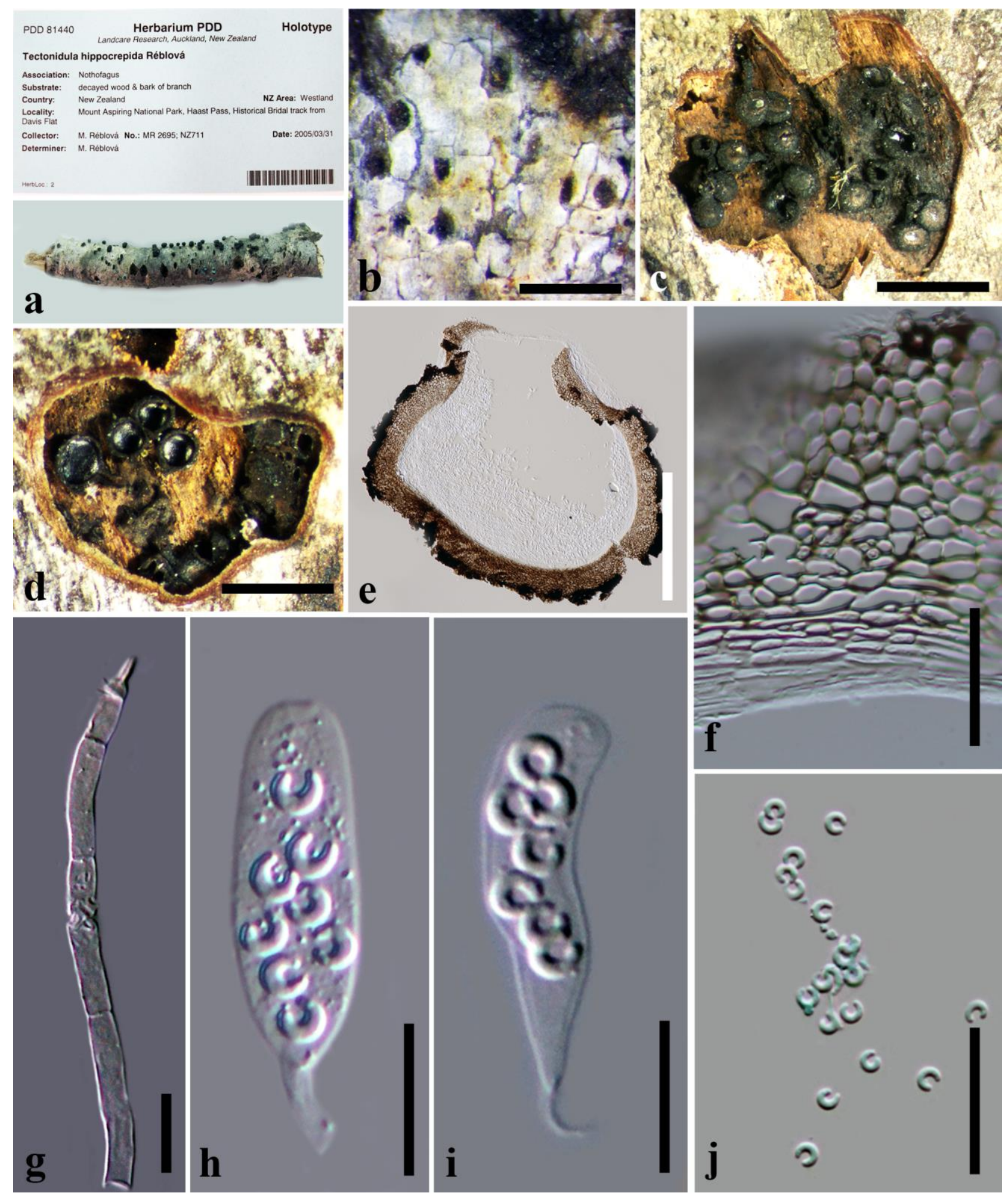

Figure 46 - Barbatosphaeria hippocrepida (PDD 81440, holotype). a Herbarium label and specimen. $b$ Perithecial necks protruding in the cortex. c, $d$ Perithecia growing on wood beneath the cortex; cortex peeled off with a razor blade. e Longitudinal section of peridium. $f$ Longitudinal section of perithecial wall. g Paraphyses. h, i Asci. j Ascospores in lactophenol cotton blue. Scale bars: $\mathrm{b}=500 \mu \mathrm{m}, \mathrm{c}, \mathrm{d}=2 \mathrm{~mm}, \mathrm{e}=100 \mu \mathrm{m}, \mathrm{f}=20 \mu \mathrm{m}, \mathrm{g}-\mathrm{i}=10 \mu \mathrm{m}, \mathrm{j}=20 \mu \mathrm{m}$.

Material examined - NEW ZEALAND, Westland, Mount Aspiring National Park, Haast Pass, Historical Bridal Track, decayed wood of branch of Nothofagus sp., 31 March 2005, M. Réblová NZ 711 (PDD 81440, holotype). 


\section{Xylariales, genera incertae sedis}

Xylariales is one of the largest orders in Sordariomycetes (subclass Xylariomycetidae) and is characterized by perithecial ascomycetes with unitunicate asci (Maharachchikumbura et al. 2015). Maharachchikumbura et al. (2016) accepted 24 genera in Xylariales, genera incertae sedis. A recent update by Wijayawardene et al. (2018) listed 44 genera in Xylariales, genera incertae sedis. Several genera previously included in Xylariales, genera incertae sedis have been treated in different families by various authors (Maharachchikumbura et al. 2015, 2016, Senanayake et al. 2015, Daranagama et al. 2018, Wijayawardene et al. 2018). Daranagama et al. (2018) revised the families Graphostromataceae, Hypoxylaceae, Lopadostomataceae and Xylariaceae in Xylariales.

Diamantinia A.N. Mill., Læssøe \& Huhndorf, Sydowia 55(1): 94 (2003)

Saprobic on decaying decorticated wood and corticated branches on the ground in dry deciduous shrubby vegetation. Sexual morph: Stromata turbinate, uni-loculate, superficial, surface minutely roughened, black. Paraphyses filiform, hyaline, septate. Ascomata uniperitheciate, globose, with yellow outer lining, superficial. Asci 8-spored, cylindrical, unitunicate, apical ring discoid, with flaring margins, amyloid. Ascospores upper cell swollen, ellipsoid, conical at apex, truncate at base, becoming pale brown then finally broadly fusiform, hyaline, initially 1-celled, becoming 2-celled, upper cell swollen, brown with a narrow, longitudinal germ slit, lower dwarf cell consisting of a small, conical, hyaline pedicel or appendage.

Type species - Diamantinia citrina A.N. Mill., Læssøe \& Huhndorf

Notes - Miller et al. (2003) introduced this monotypic genus and suggested that Diamantinia citrina belonged in the Lasiosphaeriaceae based on the filiform paraphyses and apiosporous ascospores, which are reminiscent to those of Strattonia Cif. emend. Lundq. However, phylogenetic analysis based on LSU data suggested its placement in the Xylariales. The genus exhibits an amyloid apical ring and ascospores with germ slits, which are characteristic of Xylariaceae. However, Diamantinia citrina differs from other Xylariaceae members by the shape of the paraphyses (cylindrical vs. tapering), apical ascus ring, ascospores and peridial anatomy (Miller et al. 2003). Miller et al. (2003) mentioned that the genus did not cluster with other members of Xylariaceae and hence, we prefer to keep the genus in Xylariales incertae sedis.

Diamantinia citrina A.N. Mill., Læssøe \& Huhndorf, Sydowia 55(1): 94 (2003)

Fig. 47

Index Fungorum number: IF291381; Facesoffungi number: FoF04659

Saprobic on decaying decorticated wood and corticated branches on the ground in dry deciduous shrubby vegetation. Sexual morph: Stromata 190-210 $\mu \mathrm{m}$ diam. at base, 380-600 $\mu \mathrm{m}$ diam. at apex, 450-820 $\mu \mathrm{m}$ high, turbinate, uni-loculate, superficial, surface minutely roughened, black. Paraphyses 1.5-2 $\mu \mathrm{m}$ wide, filiform, hyaline, septate. Ascomata uniperitheciate, globose, with yellow outer lining, superficial. Asci 100-145 × 7-9.5 $\mu \mathrm{m}, 8$-spored, cylindrical, unitunicate, apical ring discoid, with flaring margins, amyloid. Ascospores 12.5-15.5 $\times 4.5-6 \mu \mathrm{m}$, upper cell swollen, ellipsoid, 9.5-12.5 $\times 4.5-6 \mu \mathrm{m}$, conical at apex, truncate at base, becoming pale brown then finally broadly fusiform, initially 1-celled, becoming 2-celled by the formation of a septum, upper cell swollen, brown with a narrow, longitudinal germ slit, lower dwarf cell consisting of a small, conical, hyaline pedicel or appendage.

Material examined - BRAZIL, Bahia, Chapada Diamantina, Mcpo. Rio de Contas, lower slopes of Pico das Almas, ca. $15 \mathrm{~km} \mathrm{NW}$ of Rio de Contas on road to Brumadinho, dry rocky vegetation, on decayed corticated branches, 27 October 1994, S.M. Huhndorf, W.R. Buck \& R.C. Harris, (BUCK 26886, NY, F, isotype).

\section{Sordariomycetes, genera incertae sedis}

The genera Urupe, Phialemoniopsis and Rhizophila are treated as genera incertae sedis in Sordariomycetes. Descriptions and illustrations are provided below to further facilitate identification. DNA sequence data are required to establish a natural classification. 
Urupe Viégas, Bragantia 4(1-6): 125 (1944)

Epiphytes on surface of leaves. Mycelium intercellular, septate, hyaline to pale brown. Sexual morph: Ascostromata solitary or clustered on the surface of host. Locules globose, brown, reddish, ostiole not observed. Peridium thick, comprising layer of textura angularis cells, outer layer darker brown. Hamathecium aparaphysate. Asci 8-spored, unitunicate, clavate to broadly cylindrical, thinwalled, with short and round pedicel. Ascospores fusiform, 1-septate, not constricted at the septum, hyaline, narrowed ends, upper cell slightly broader than lower cell, guttulate, but smooth-walled when in Melzer's reagent. Asexual morph: Undetermined.

Type species - Urupe guaduae Viégas

Notes - Urupe was introduced by Viégas (1944), and it is a monotypic genus. Urupe is characterized by intercellular hyphae, branched, septate, reddish ascomata, 8-spored, clavate asci, lacks paraphyses, and has 3-septate, hyaline ascospores. Hongsanan et al. (2015) treated the genus as doubtful genus in Sordariomycetes based on morphology illustrated by Viégas (1944). Hongsanan et al. (2015) were unable to examine the type specimen of Urupe guaduae. However, they excluded this species from Meliolales because of its hyaline ascospores and non-hyphopodiate hyphae as described by Viégas (1944). We examined the type specimen and found that it has larger ascostromata (up to $300 \mu \mathrm{m}$ ), and 1-septate ascospores, while the original description reported smaller ascostromata (100-120 $\mu \mathrm{m}$ diam., Viégas 1944), with 3-septate ascospores. Based on our observations, the ascospores appear to be 2 or 3 -septate when in the ascus because they overlap with one another. Based on the morphological characters of Urupe guaduae from both the original description and our study, we agree that this species should be excluded from Meliolales. The taxon may have similarities with Phyllachorales, however we placed it as a genus incertae sedis in Sordariomycetes until it can be sequenced.

Urupe guaduae Viégas, Bragantia 4(1-6): 125 (1944)

Fig. 48

Index Fungorum number: IF291870; Facesoffungi number: FoF04659

Epiphytes on surface of leaves. Mycelium intercellular, septate, hyaline to pale brown. Sexual morph: Ascostromata up to $300 \mu \mathrm{m}$ diam., solitary or clustered on the surface of host. Locules 150-240 $\mu \mathrm{m}$, globose, brown, reddish, ostiole not observed. Peridium 32-45 $\mu \mathrm{m}(\bar{x}=40 \mu \mathrm{m}, \mathrm{n}=$ 5), comprising layer of textura angularis cells, outer layer darker brown. Hamathecium aparaphysate. Asci $64-78 \times 13-18 \mu \mathrm{m}(\bar{x}=74 \times 15 \mu \mathrm{m}, \mathrm{n}=10), 8$-spored, unitunicate, clavate to broadly cylindrical, thin-walled, with short and round pedicel. Ascospores $31-35 \times 3-5 \mu \mathrm{m}(\bar{x}=$ $34 \times 4 \mu \mathrm{m}, \mathrm{n}=10$ ), fusiform, 1-septate, not constricted at the septum, hyaline, narrowed ends, upper cell slightly broader than lower cell, guttulate, but smooth-walled when in Melzer's reagent. Asexual morph: Undetermined.

Material examined - BRAZIL, Morro do Aipim, Blumenau, État de Santa Catarina, on living leaves of Guadua sp., 28 October 1935, Nina Raeder 1289 (IAC, holotype).

Phialemoniopsis Perdomo, Dania García, Gené, Cano \& Guarro, Mycologia 105(2): 408 (2013)

Endophytic on stem of plant and pathogenic on humans. Sexual morph: Undetermined. Asexual morph: Conidiomata pycnidium-like, globose to subglobose, dark brown to black. Conidiophores branched, aseptate, hyaline. Conidiogenous cells monophialidic, discrete, terminal or lateral, cylindrical to flask-shaped, straight to slightly flexuose, or intercalary with a cylindrical lateral projection. Conidia ellipsoidal to slightly allantoid, slightly curved, hyaline.

Type species - Phialemoniopsis ocularis (Gené \& Guarro) Perdomo, Dania García, Gené \& Guarro

Notes - The genus Phialemoniopsis was proposed to accommodate the opportunistic taxon Phialemonium curvatum, Sarcopodium oculorum and two new species, Phialemoniopsis cornearis and Phialemoniopsis pluriloculosa (Perdomo et al. 2013). The taxonomy of Phialemoniopsis has not been completely resolved, however, we place the genus in Sordariomycetes genera incertae sedis agreeing with Perdomo et al. (2013) and Wijayawardene et al. (2018). The genus currently comprises six species (Wijayawardene et al. 2017a). 

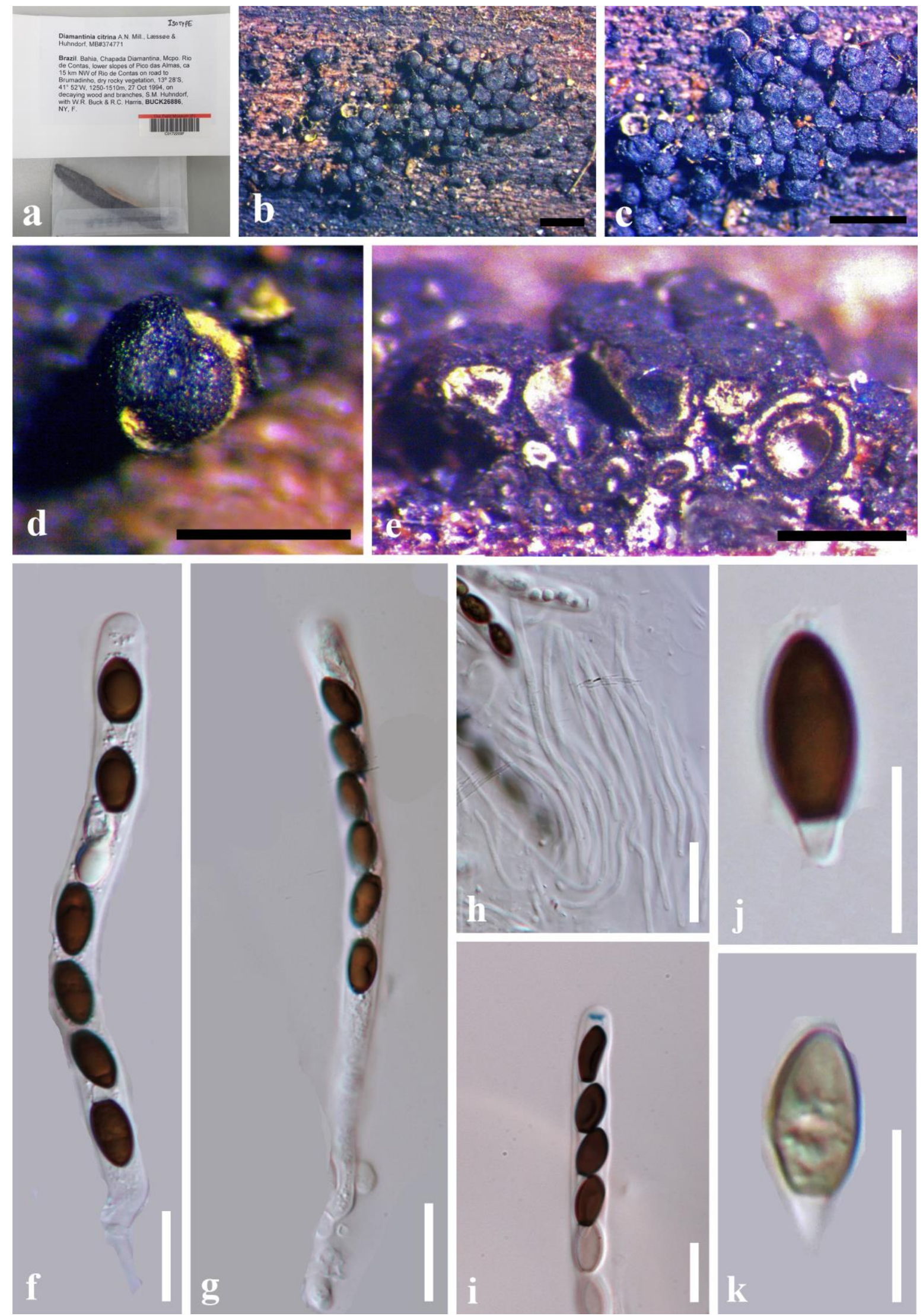

Figure 47 - Diamantinia citrina (BUCK 26886, isotype). a Details of herbarium and specimen. $\mathrm{b}$, c Stromata on wood. d Stroma with yellow pigments. e Cross section of stromata showing perithecia encased in stromatal tissue. f, g Mature asci. h Paraphyses. i Ascus with apical ring bluing in Melzer's reagent. j, k Ascospores. Scale bars b, $c=1000 \mu \mathrm{m}, \mathrm{d}, \mathrm{e}=500 \mu \mathrm{m}, \mathrm{f}-\mathrm{i}=10 \mu \mathrm{m}$, $\mathrm{j}, \mathrm{k}=15 \mu \mathrm{m}$. 


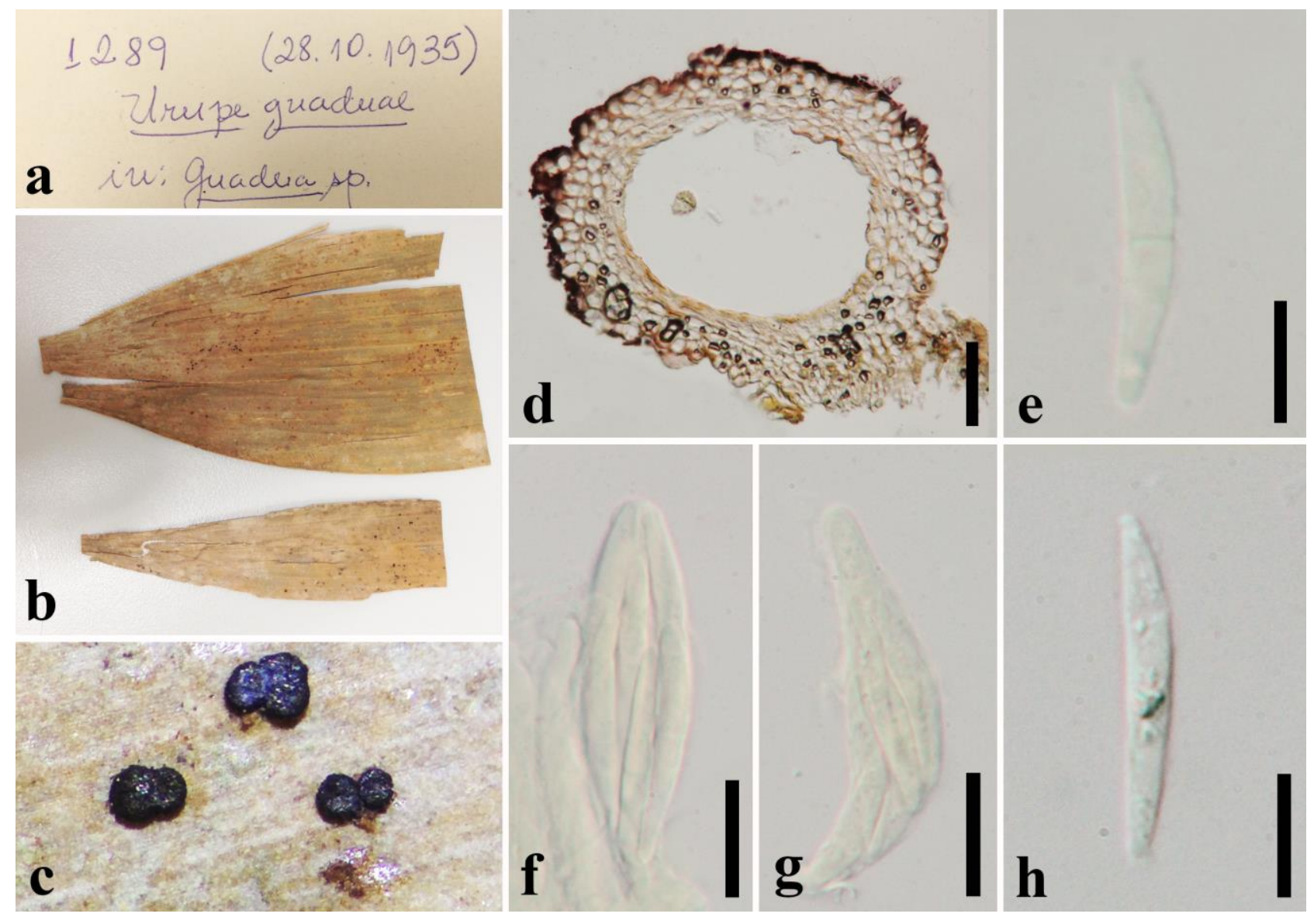

Figure 48 - Urupe guaduae (IAC, holotype). a, b Herbarium label and specimen. c Ascostromata on surface of plant. d Section through ascostroma. e Ascospore in Melzer's reagent. $f$, g Asci in Melzer's reagent. h Ascospore. Scale bars: $d=50 \mu \mathrm{m}, \mathrm{e}, \mathrm{h}=10 \mu \mathrm{m}, \mathrm{f}, \mathrm{g}=20 \mu \mathrm{m}$.

Phialemoniopsis ocularis (Gené \& Guarro) Perdomo, Dania García, Gené \& Guarro, Mycologia 105(2): 411 (2013)

三 Sarcopodium oculorum Gené \& Guarro, in Guarro, Höfling-Lima, Gené, De Freitas, Godoy, Zorat-Yu, Zaror \& Fischman (2002)

Index Fungorum number: IF563877; Facesoffungi number: FoF04661

Pathogenic on humans. Sexual morph: Undetermined. Asexual morph: Conidiomata 200-450 $\times 100-580 \mu \mathrm{m}(\bar{x}=370 \times 340 \mu \mathrm{m}, \mathrm{n}=5)$, pycnidium-like, globose to subglobose, dark brown to black. Conidiophores $2-18 \times 1-2 \mu \mathrm{m}(\bar{x}=10 \times 1.5 \mu \mathrm{m}, \mathrm{n}=20)$, branched, aseptate, hyaline. Conidiogenous cells monophialidic, discrete, terminal or lateral, cylindrical to flask-shaped, straight to slightly flexuose, or intercalary with a cylindrical lateral projection. Conidia 3-4 $\times 1-1.5$ $\mu \mathrm{m}(\bar{x}=3 \times 1 \mu \mathrm{m}, \mathrm{n}=20)$, ellipsoidal to slightly allantoid, slightly curved, hyaline.

Material examined - BRAZIL, São Paulo, from cornea of Homo sapiens, 2000, O. Fischman (IMI 387421, holotype).

Rhizophila K.D. Hyde \& E.B.G. Jones, Mycotaxon 34(2): 527 (1989)

Saprobic on dead wood. Sexual morph: Ascomata immersed, subglobose to ellipsoidal, solitary or gregarious, dark brown to black ostiolate, papillate, periphysate. Periphyses aseptate, hyaline. Peridium outer layer composed of irregular hyphae, dark brown to black, inner layer composed of elongated cells which fuse with the paraphyses-like structures, light brown to brown; paraphyses-like structures comprising irregular shaped cells, septate. Asci 8-spored, clavate, pedunculate, unitunicate, thin-walled with an indistinct apical thickening, slightly truncate, without an apical ring. Ascospores ellipsoidal to fusiform, 1-celled, hyaline to brown. Asexual morph: Undetermined. 
Type species - Rhizophila marina K.D. Hyde \& E.B.G. Jones

Notes - The genus Rhizophila is characterized by relatively large, periphysate, ascomata with paraphyses-like structures, yellowish brown to brown, 1-celled ascospores and clavate, unitunicate asci. This genus was introduced by Hyde \& Jones (1989) and is typified by $R$. marina which was isolated from prop roots and branches of Rhizophora mucronata. Hyde \& Jones (1989) stated that it has affinities to the family Phyllachoraceae but is distinct by thick-walled ascomata and asci lacking apical rings. Rhizophila marina has been reported from various locations including Seychelles, Brunei, Thailand, North Sumatra, Andaman and Nicobar Island and India (Hyde 1989, Sarma et al. 2001). The genus lacks molecular data in GenBank and its phylogenetic placement is uncertain, hence, the genus is placed in Sordariomycetes incertae sedis (Maharachchikumbura et al. 2016, Wijayawardene et al. 2018).

Rhizophila marina K.D. Hyde \& E.B.G. Jones, Mycotaxon 34(2): 528 (1989)

Fig. 50

Index Fungorum number: IF135911; Facesoffungi number: FoF04662

Saprobic on dead wood. Sexual morph: Ascomata 350-700 $\times 400-840 \mu \mathrm{m}$ immersed, subglobose to ellipsoidal, solitary or gregarious, dark brown to black ostiolate, papillate, periphysate. Periphyses 3-10 $\mu \mathrm{m}$ wide, aseptate, hyaline. Peridium 30-145 $\mu \mathrm{m}$ thick, 2-layered, outer layer composed of irregular hyphae, dark brown to black, inner layer composed of elongated cells which fuse with the paraphyses-like structures, light brown to brown; paraphyses-like structures comprising irregular-shaped cells, septate. Asci 8-spored, 2-3-seriate, clavate, pedicellate, unitunicate, thin-walled with an indistinct apical thickening, slightly truncate, without an apical ring. Ascospores $25-38 \times 10-14 \mu \mathrm{m}(\bar{x}=32.5 \times 12 \mu \mathrm{m}, \mathrm{n}=10)$, ellipsoidal to fusiform, 1-celled, hyaline to brown. Asexual morph: Undetermined.

Material examined - SEYCHELLES, from Rhizophora sp. (Rhizophoraceae), December 1984, K.D. Hyde (IMI 325411, holotype).

\section{Ascomycota, families incertae sedis}

Saccardiaceae Höhn., Sber. Akad. Wiss. Wien, Math.-naturw. Kl., Abt. 1 118: 369 [95 repr.] (1909)

\section{Facesoffungi number: FoF04663}

Saprobic on leaves. Sexual morph: Ascomata superficial on host tissue, globose to subglobose, initially pale yellow, becoming brown to dark brown, loose, fleshy and soft, solitary or gregarious, ostiole not seen. Peridium very thin-walled, composed of pale yellow to brown cells. Hamathecium lacking. Asci 8-spored, bitunicate, globose to ovoid or saccate, sessile or with pedicel. Ascospores 2-3-seriate, hyaline, oblong to ellipsoidal, with obtuse to rounded ends, muriform. Asexual morph: Undetermined.

Notes - The families Phaeothecoidiellaceae, Saccardiaceae and Schizothyriaceae are a poorly understood assemblage of genera, which mostly lack sequence data. The types of Saccardiaceae and Schizothyriaceae need to be recollected to establish their phylogenetic relationships with other ascomata groups. We provide notes and illustrations for one genus placed in Saccardiaceae and suggest tentative placements for other taxa which were formerly placed in Saccardiaceae in Wijayawardene et al. (2018), acknowledging that they need to be recollected and sequenced to confirm our suggestions.

The family Saccardiaceae was established by Höhnel (1909a). Taxa are mostly saprobic on living or dead plants. The understanding of the family by von Arx \& Müller (1975) was as follows. Ascomata are small and discoid, disc convex or pulvinate and hyphae develop superficially on the cuticle of leaves or other plant parts, asci are surrounded by numerous pseudoparaphyses, forming an epithecium, mostly saccate, thick-walled, fissitunicate and ascospores are 2-3-celled or multicelled and hyaline or brown. The family comprises 13 genera and has been placed as family incertae sedis within the Ascomycota (Lumbsch \& Huhndorf 2010, Wijayawardene et al. 2018). 

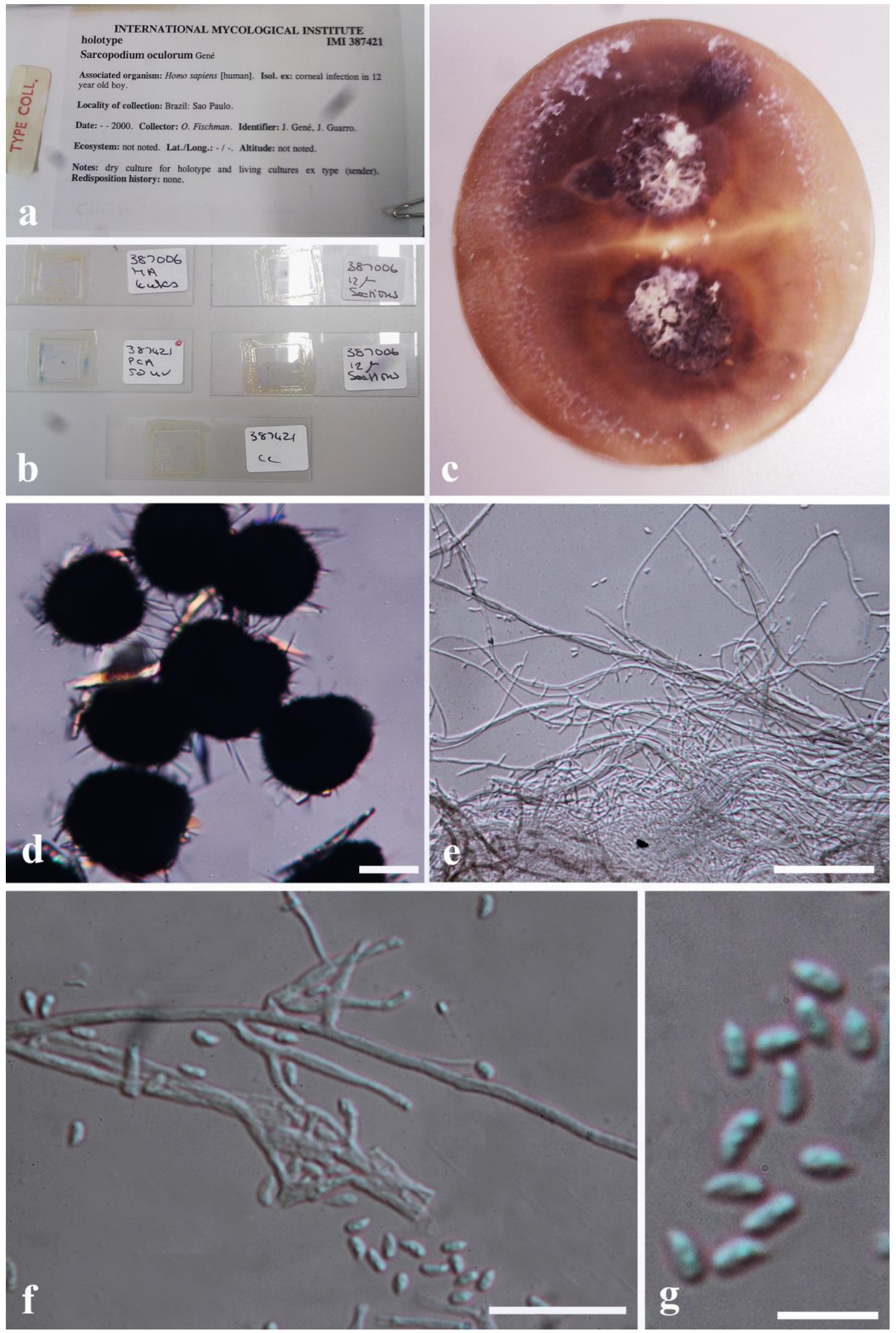

Figure 49 - Phialemoniopsis ocularis (IMI 387421, holotype). a Herbarium label. b Microslides. c Dried culture. d Pycnidium-like conidiomata. e, f Conidiophores and conidia. g Conidia. Scale bars: $\mathrm{d}=50 \mu \mathrm{m}, \mathrm{e}=20 \mu \mathrm{m}, \mathrm{f}-\mathrm{g}=10 \mu \mathrm{m}$. 


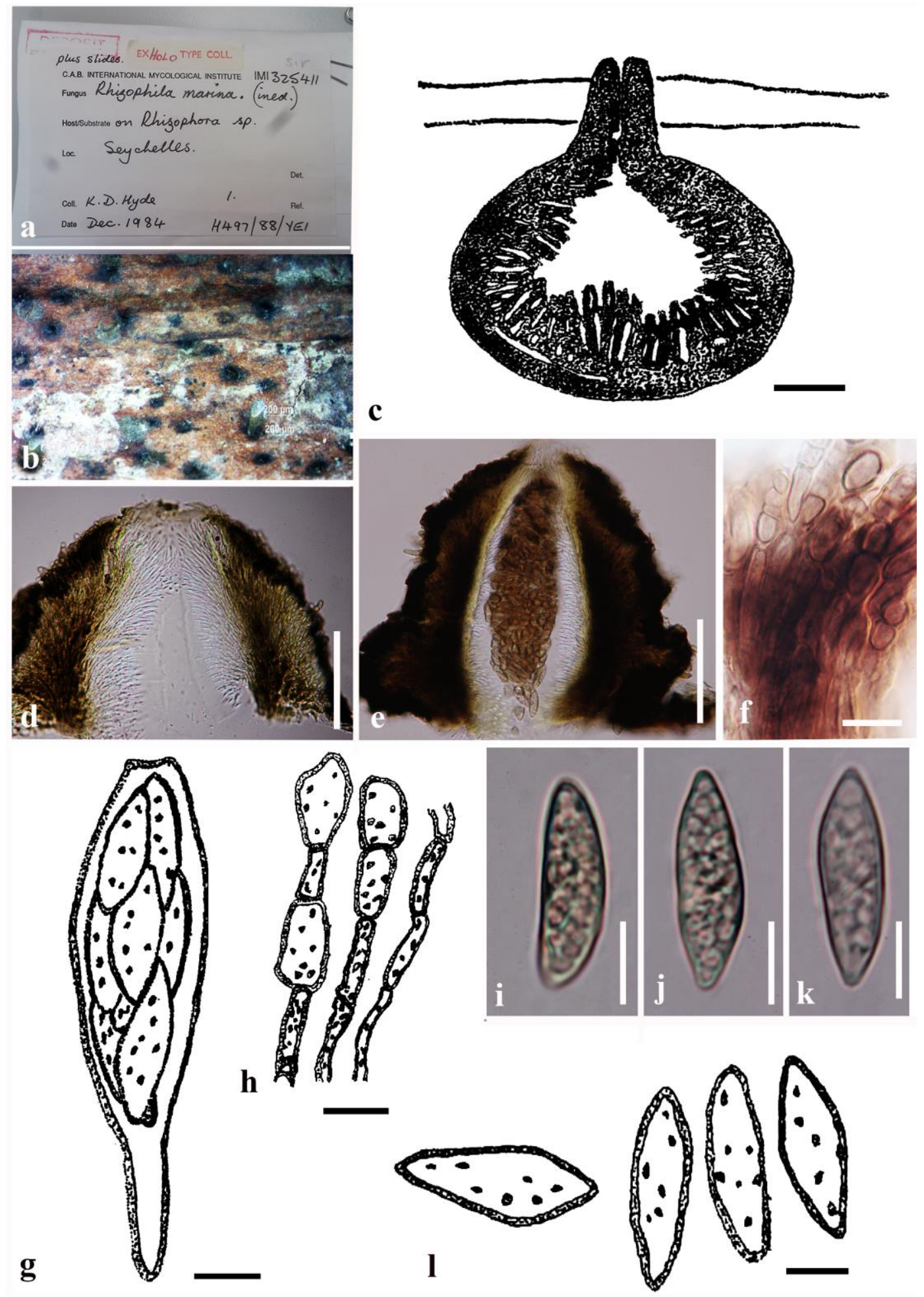

Figure 50 - Rhizophila marina (IMI 325411, holotype). a Herbarium label. b Ascomata on host surface. c Diagrammatic representation of vertical section through ascoma. d, e Papilla. f Peridium. $\mathrm{g}$ Diagrammatic representation of ascus with ascospores. $\mathrm{h}$ Diagrammatic representation of Paraphyses-like structures. i-k Ascospores. 1. Diagrammatic representation of ascospores. (c, g, h, 1 redrawn from Hyde \& Jones (1989), Figs. 1-5). Scale bars: $c=100 \mu \mathrm{m}, \mathrm{d}, \mathrm{e}, 1=10 \mu \mathrm{m}, \mathrm{f}=50 \mu \mathrm{m}$, $\mathrm{g}-\mathrm{k}=5 \mu \mathrm{m}$.

The family is based on Saccardia which is illustrated from material of S. quercina Cooke in H.W. Ravenel American Exsicata and can be considered part of the type as the collection details match. The globose to ovoid or saccate asci are enclosed in very thin-walled, small ascomata 
similar to Translucidithyrium thailandicum in Phaeothecoidiellaceae (Zeng et al. 2018). The muriform ascospores, however, are unlike members of Phaeothecoidiellaceae We maintain the family Saccardiaceae based on Saccardia quercina and include the genera Ascolectus, Cyanodiscus, Henningsiella, Phillipsiella, Pseudodiscus and Schenckiella. We were unable to examine Ascolectus, Cyanodiscus, Phillipsiella, Pseudodiscus, and Schenckiella so these remain in Saccardiaceae pending further study. Phookamsak et al. (2016) provided a description and illustration of Henningsiella and tentatively placed it in Saccardiaceae until molecular phylogeny is available to clarify its natural placement.

We maintain the family Saccardiaceae to accommodate Saccardia, plus other genera, which were previously placed in this family that we have not been able to examine. The family is characterized by minute ascomata, surrounded by brown mycelial network forming plectenchymatous tissue, with very thin walls and rounded asci with eight muriform ascospores and a habit on leaves. The asexual morph is unknown (Wijayawardene et al. 2017b).

Saccardia Cooke, Grevillea 7(no. 42): 49 (1878)

Facesoffungi number: FoF04664

Saprobic on leaves. Sexual morph: Ascomata superficial on host tissue, visible as dark area on the lower side of host, easily removed, globose to subglobose, initially pale yellow, becoming brown to dark brown, loose, fleshy and soft, solitary or gregarious, ostiole not seen. Peridium thinwalled, composed of pale yellow to brown cells. Pseudoparaphyses lacking. Asci 8-spored, bitunicate, globose to ovoid or saccate, sessile. Ascospores hyaline, oblong to ellipsoidal, with obtuse to rounded ends, muriform. Asexual morph: Undetermined.

Type species - Saccardia quercina Cooke

Notes - The genus Saccardia was established by Cooke (1878) with S. quercina Cooke as the type species. The genus consists of three species epithets (Index Fungorum 2018). Saccardia is characterized by discoid ascomata developing on a superficial mycelium. Ascospores are hyaline, multi-septate with transverse and longitudinal septa (von Arx \& Müller 1975).

Saccardia quercina Cooke, Grevillea 7(no. 42): 49 (1878)

Fig. 51

Index Fungorum number: IF208462; Facesoffungi number: FoF04665

Saprobic on leaves of Quercus virens. Sexual morph: Ascomata 95-130 $\mu \mathrm{m}$ high $\times 100-145$ $\mu \mathrm{m}$ diam. $(\bar{x}=115 \times 120 \mu \mathrm{m}, \mathrm{n}=10)$, superficial on host tissue, visible as dark area on the lower side of host, easily removed, globose to subglobose, initially pale yellow, becoming brown to dark brown, loose, fleshy and soft, solitary or gregarious, ostiole not seen. Peridium thin-walled, composed of pale yellow to brown, granular cells. Pseudoparaphyses lacking. Asci 38-65 × 35-49 $\mu \mathrm{m}(\bar{x}=45 \times 41 \mu \mathrm{m}, \mathrm{n}=20), 8$-spored, bitunicate, fissitunicate, globose to ovoid or saccate, sessile, apically rounded. Ascospores 20-25 $\times 9-12 \mu \mathrm{m}(\bar{x}=23 \times 11 \mu \mathrm{m}, \mathrm{n}=25), 2-3$-seriate, hyaline, oblong to ellipsoidal, with obtuse to rounded ends, muriform, with 6 transverse septa and 1-2 longitudinal septa, wall rough, constricted or not at the septa, apical cell mostly larger than basal cell. Asexual morph: Undetermined.

Material examined - USA, Georgia, Darien, on leaves of Quercus virens Aiton (Fagaceae), H.W. Ravenel Americiana Exsiccata (BPI 566019, type).

\section{Strangosporaceae S. Stenroos, Miądl. \& Lutzoni}

The monogeneric family Strangosporaceae was introduced by Miadlikowska et al. (2014) to accommodate Strangospora Körb., which was removed from the order Lecanorales. It was initially placed in Lecanoromycetes, families incertae sedis by Miadlikowska et al. (2014) based on analysis of combined mitSSU, nucLSU, nucSSU, RPB1 and RPB2 sequences, but they suspected that it might be outside of the class Lecanoromycetes. Recently, Wijayawardene et al. (2018) placed the family in Ascomycota, families incertae sedis. The family comprises epiphytic, epixylic or bryophylous lichens with crustose and often poorly developed thalli associated with a chlorococcoid photobiont (Miadlikowska et al. 2014). Strangospora is characterized by biatorine 
apothecia with poorly developed exciple, clavate, multi-spored asci with gelatinous outer layer, a strongly thickened, I+, blue wall and apical dome and aseptate ascospores (Miadlikowska et al. 2014). The asexual morphs are undetermined (Wijayawardene et al. 2017b).
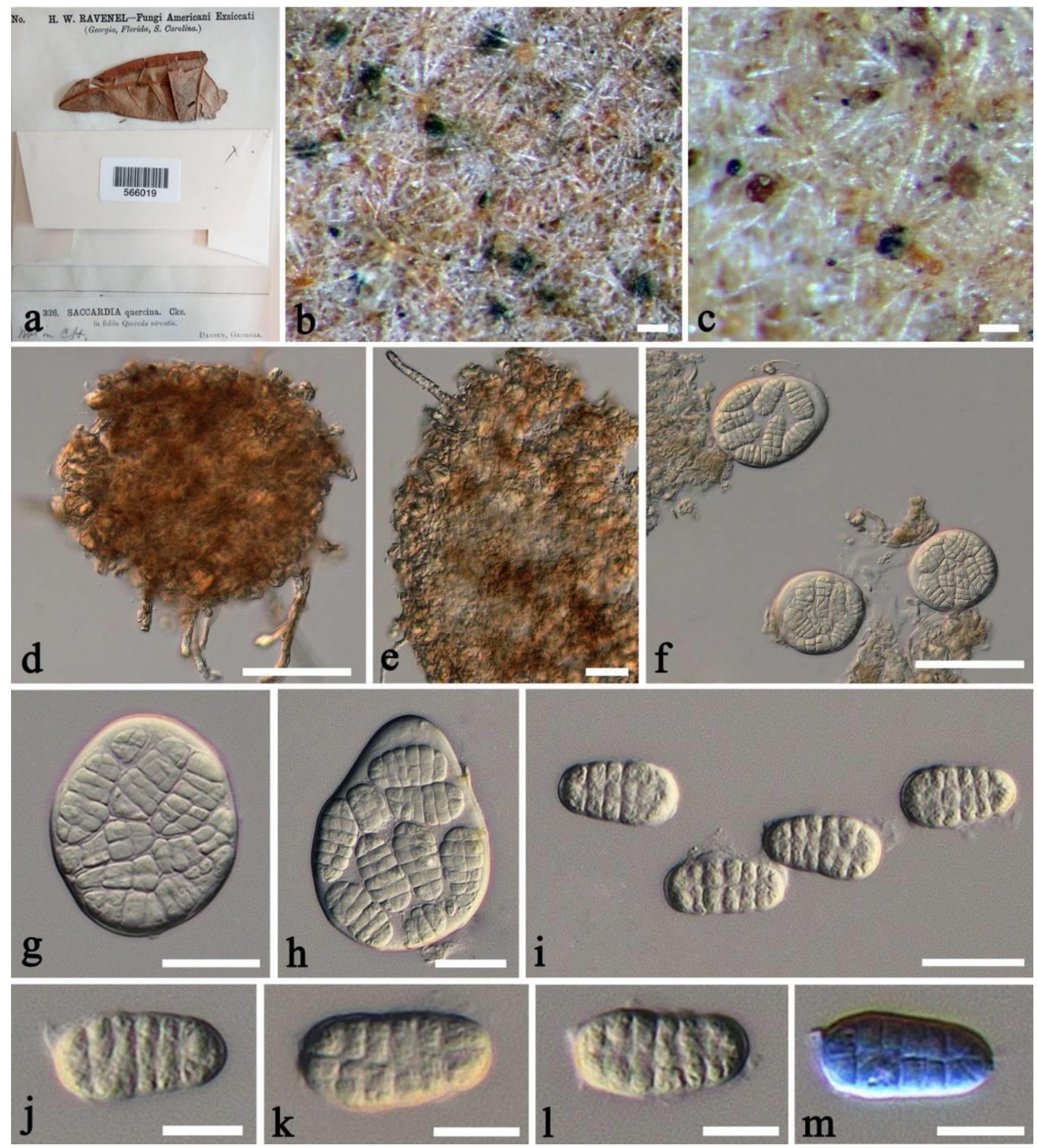

Figure 51 - Saccardia quercina (BPI 566019, type). a Herbarium label and specimen. $\mathrm{b}$, c Ascomata on host surface. d Ascoma. e Peridium structure seen from above. $\mathrm{f}-\mathrm{h}$ Asci. $\mathrm{i}-\mathrm{l}$ Ascospores. $\mathrm{m}$ Ascospore stained in lactophenol cotton blue. Scale bars: $\mathrm{b}, \mathrm{c}=200 \mu \mathrm{m}, \mathrm{d}, \mathrm{f}=50$ $\mu \mathrm{m}, \mathrm{e}, \mathrm{g}, \mathrm{h}, \mathrm{i}=20 \mu \mathrm{m}, \mathrm{j}-\mathrm{m}=10 \mu \mathrm{m}$.

Strangospora Körb., Parerga lichenol. (Breslau) 2: 173 (1860)

Lichenized on wood. Sexual morph: Apothecia black, solitary, gregarious or confluent, superficial, pulvinate. Apothecial wall composed of hyaline to brown, moderately thick-walled cells 
of texura angularis. Hymenium layer composed of asci and paraphyses, with a crust-like excipulum above. Hamathecium dense, hyaline, filamentous, hyphoid, septate, unbranched. Asci hyaline, bitunicate, wedge-shaped, broadly rounded above, narrow below, pedicellate, many-spored. Ascospores hyaline, multiseriate, irregularly arranged in the asci, globose, cupulate, smooth and thick-walled, aseptate. Asexual morph: Undetermined.

Type species - Strangospora pinicola (A. Massal.) Körb.

Notes - Strangospora was established by Körber (1860) with the type species S. pinicola. Reeb et al. (2004) excluded Strangospora from the subclass Acarosporomycetidae, family Acarosporaceae based on phylogenetic analyses using isolates of $S$. pinicola, and listed genera included in Acarosporaceae. The genus was placed as an uncertain genus in Lecanoromycetes by Eriksson (2006) and placed outside all families sampled from the order Lecanorales with high support by Miadlikowska et al. (2006). Lumbsch \& Huhndorf (2007, 2010) accepted Strangospora in Lecanorales genera incertae sedis. Miadlikowska et al. (2014) removed Strangospora from Lecanorales and placed it in family Strangosporaceae, in Lecanoromycetes incertae sedis. Lücking et al. (2016) accepted Strangospora in the subphylum Pezizomycotina, Strangosporaceae, families incertae sedis.

Strangospora moriformis (Ach.) Stein, in Cohn, Krypt.-Fl. Schlesien (Breslau) 2(2): 176 (1879)

三Arthonia moriformis Ach., Syn. meth. lich. (Lund): 5 (1814)

Fig. 52

三Biatorella moriformis (Ach.) Th. Fr., Lich. Scand. (Upsaliae) 1(2): 401 (1874)

Index Fungorum number: IF406603; Facesoffungi number: FoF04666

Lichenized on wood. Sexual morph: Apothecia 210-220 $\mu \mathrm{m}$ diam., 355-365 $\mu \mathrm{m}$ high, black, solitary, gregarious or confluent, superficial, pulvinate. Apothecial wall 10-15 $\mu \mathrm{m}$ wide, composed of hyaline to brown, moderately thick-walled cells of texura angularis. Hymenium layer composed of asci and paraphyses, with a crust-like excipulum above. Hamathecium 1.5-2.5 $\mu \mathrm{m}$ wide, hyaline, filamentous, hyphoid, septate, unbranched, dense. Asci 34-88 $\times 18-60 \mu \mathrm{m}(\bar{x}=65 \times 32, \mathrm{n}=20)$, hyaline, bitunicate, wedge-shaped, broadly rounded above, narrow below, pedicellate, manyspored. Ascospores $2.5-4.5 \times 2.5-3 \mu \mathrm{m}(\bar{x}=3.5 \times 2.8, \mathrm{n}=10)$, hyaline, multiseriate, irregularly arranged in the asci, globose, cupulate, smooth and thick-walled, aseptate. Asexual morph: Undetermined.

Material examined - SWEDEN, Jämtland, Undersåker, Rista., on wood, 1917, G.O.A. Malme (H).

\section{Pezizomycotina, genus incertae sedis}

Thelenidia Nyl., Flora, Regensburg 69: 463 (1886)

Lichen on pyrenocarp. Superficial mycelium absent. Sexual morph: Ascomata semiimmersed, solitary, globose to subglobose, dark brown to black, ostiole not observed. Peridium 2 layers, inner layer with hyaline textura angularis cells, outer layer with dark brown to black textura angularis cells. Hamathecium comprising paraphyses, embedded in a gelatinous matrix. Asci 1spored, unitunicate, clavate, ocular chamber absent, long pedicel when young. Ascospores aseptate, obovoid, upper part broader than lower part, slightly constricted at the middle, verrucose, hyaline when immature, brown at maturity. Asexual morph: Undetermined.

Type species - Thelenidia monosporella Nyl.

Notes - Thelenidia monosporella was established by Nylander (1886) to accommodate $T$. monosporella. Thelenidia is placed in Dothideomycetes, genera incertae sedis (Wijayawardene et al. 2014) based on morphology such as habitat in lichens, 1-spored asci and aseptate ascospores. Lücking et al. (2016) changed its classification from Dothideomycetes to Pezizomycotina incertae sedis. There are no any other collections that can represent the characters of this species, and no sequence data to clarify its placement. We followed Lücking et al. (2016) and placed it in Pezizomycotina incertae sedis. 

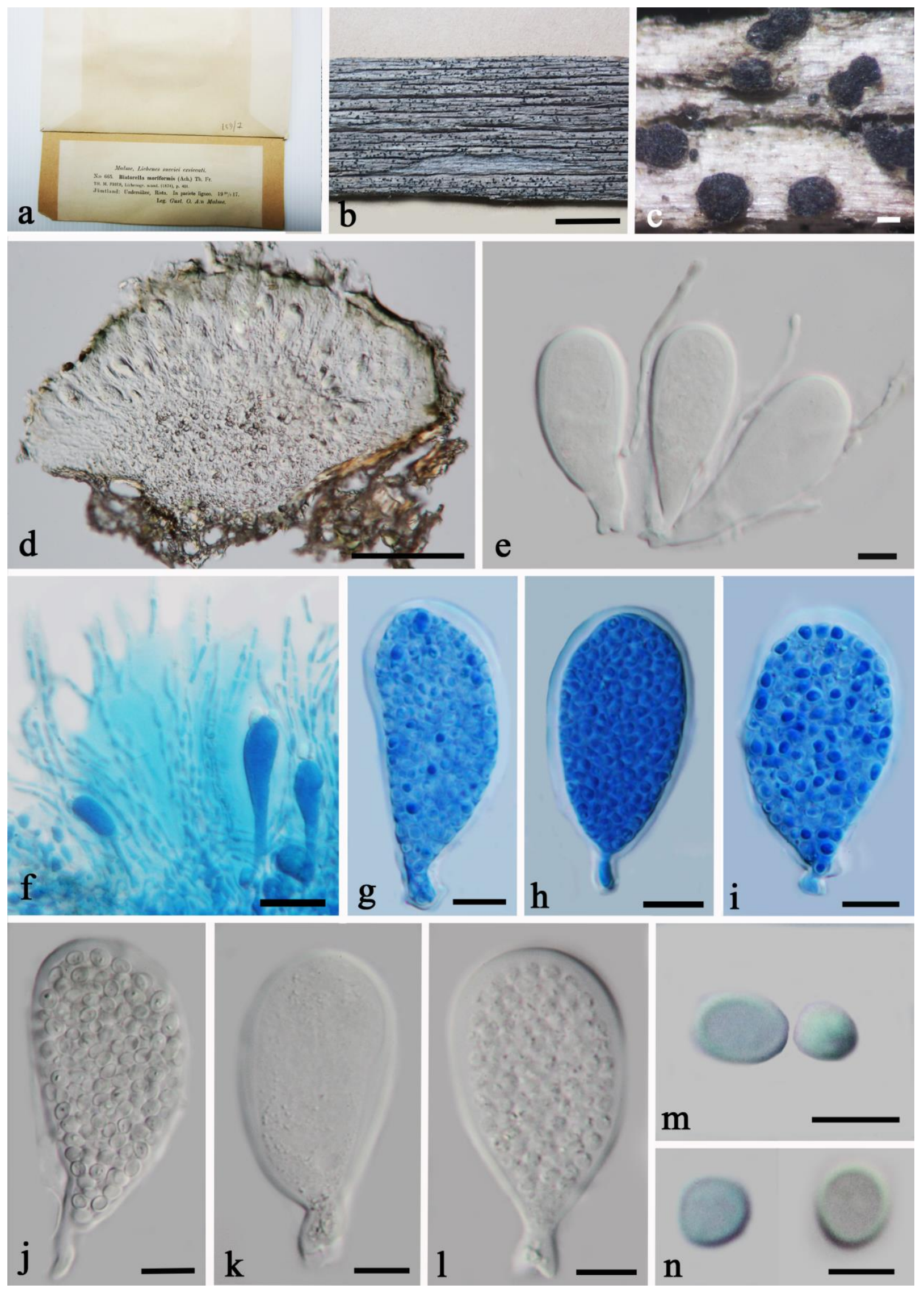

Figure 52 - Strangospora moriformis. a Herbarium label. b Herbarium specimen. c Appearance of black apothecia on the host. d Vertical section of apothecium with asci inside. e, f Paraphyses and asci. g-l Asci. $\mathrm{m}-\mathrm{n}$ Ascospores. Note: $\mathrm{f}-\mathrm{i}, \mathrm{m}, \mathrm{n}$ stained in lactophenol cotton blue. Scale bars: $\mathrm{b}=$ $20 \mathrm{~mm}, \mathrm{c}=100 \mu \mathrm{m}, \mathrm{d}=100 \mu \mathrm{m}, \mathrm{e}, \mathrm{g}-1=10 \mu \mathrm{m}, \mathrm{f}=20 \mu \mathrm{m}, \mathrm{m}, \mathrm{n}=5 \mu \mathrm{m}$. 
Index Fungorum number: IF406941; Facesoffungi number: FoF04657

Lichen on pyrenocarp. Superficial mycelium absent. Sexual morph: Ascomata 360-410 $\mu \mathrm{m}$ diam. ( $\bar{x}=385 \mu \mathrm{m}, \mathrm{n}=3$ ), semi-immersed, solitary, globose to subglobose, dark brown to black, ostiole not observed. Peridium $65-72 \mu \mathrm{m}(\bar{x}=67 \mu \mathrm{m}, \mathrm{n}=10), 2$ layers, inner layer with hyaline textura angularis cells, outer layer with dark brown to black textura angularis cells. Hamathecium of $1 \mu \mathrm{m}$, hyaline, paraphyses, embedded in a gelatinous matrix. Asci $68-75 \times 25-30 \mu \mathrm{m}(\bar{x}=71 \times$ $28 \mu \mathrm{m}, \mathrm{n}=10$ ), 1-spored, unitunicate, clavate, ocular chamber absent, long pedicel when young. Ascospores $49-58 \times 22-25 \mu \mathrm{m}(\bar{x}=56 \times 24 \mu \mathrm{m}, \mathrm{n}=20)$, aseptate, obovoid, upper part broader than lower part, slightly constricted in middle, verrucose, hyaline when immature, brown at maturity. Asexual morph: Undetermined.

Material examined - SWITZERLAND, Helvetia, in Lichens, Hegetschweiler (H 4060, syntype).
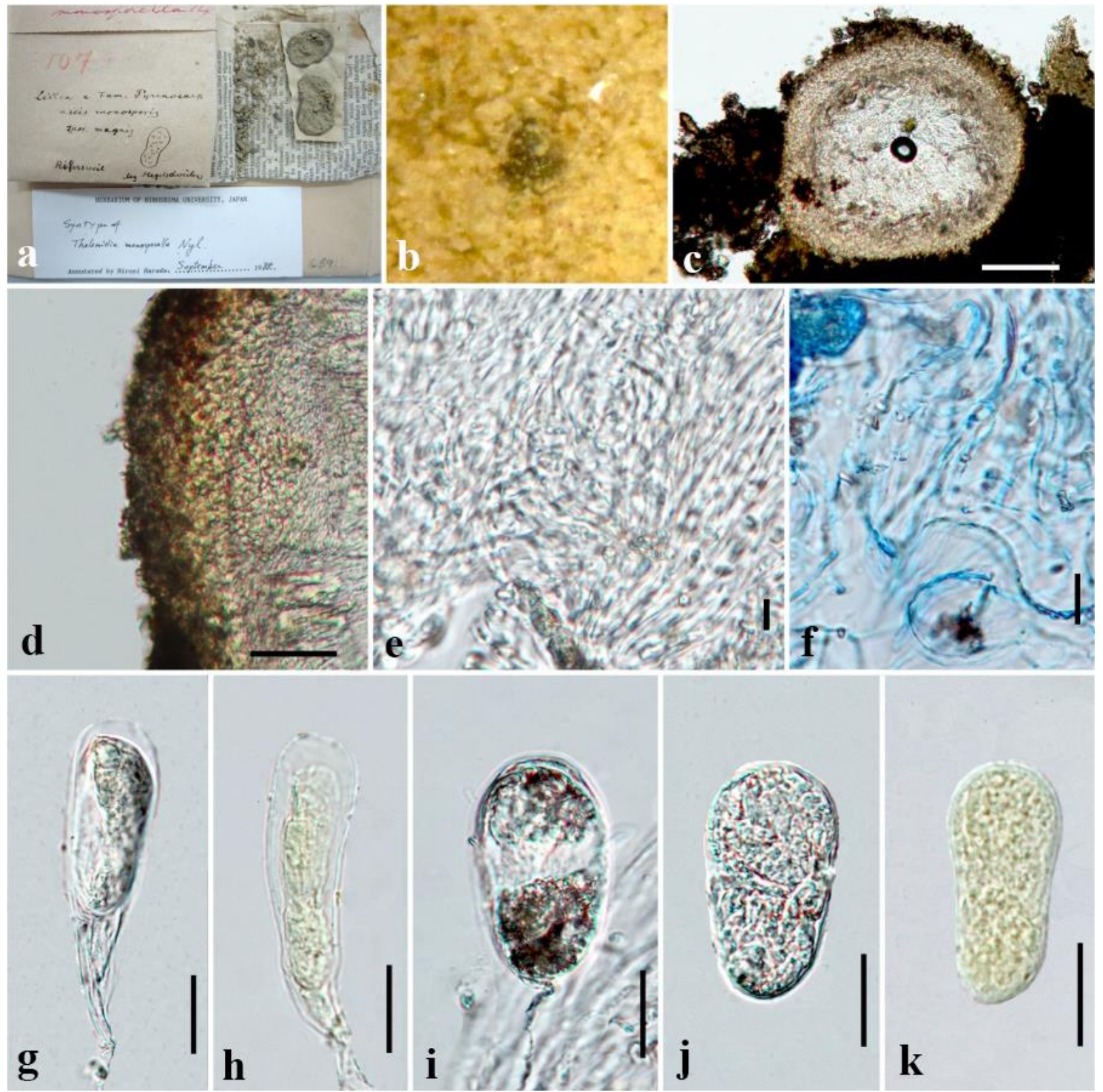

Figure 53 - Thelenidia monosporella (H 4060, syntype). a Herbarium label and specimen. b Ascoma on substrate. c Vertical section through ascoma. d Peridium. e Paraphyses. f Paraphyses in lactophenol cotton blue reagent. g Ascus. h Ascus in Melzer's reagent. i, j Ascospores. $\mathrm{k}$ Ascospore in Melzer's reagent. Scale bars: $\mathrm{c}=100 \mu \mathrm{m}, \mathrm{d}=20 \mu \mathrm{m}, \mathrm{e}, \mathrm{f}=5 \mu \mathrm{m}, \mathrm{g}-\mathrm{k}=20 \mu \mathrm{m}$. 


\section{Doubtful genus}

Angatia Syd. \& P. Syd., Annls mycol. 12(6): 566 (1914)

Epiphytic on living leaves, or associated with scale insects. Sexual morph: Ascomata superficial, discoid, dark to reddish brown, rounded or irregular, solitary or scattered, easily removed from the host, apothecium-like, with or without a basal hypostroma developing in the host tissue. Peridium dark, isodiametric, thick-walled. Asci 6-8-spored, bitunicate, ellipsoidal to cylindrical, subsessile to short pedicel, broadly rounded at the apex. Ascospores hyaline to brown, muriform, with transverse and longitudinal septa, oblong to ellipsoidal, broadly rounded at both ends, not constricted at the septa. Asexual morph: Undetermined.

Type species - Angatia eugeniae Syd. \& P. Syd.

Notes - Angatia was introduced by Sydow \& Sydow (1914) and is typified by A. eugeniae. von Arx \& Müller (1975) placed Angatia in Saccardiaceae, while Barr (1987) placed it in Myriangiaceae. It was subsequently accepted in Saccardiaceae (Lumbsch \& Huhndorf 2007, 2010, Wijayawardene et al. 2017a, 2018). Angatia thwaitesii has been reported from scale insects (Sydow \& Sydow 1914, von Arx 1963, Batista et al. 1966). The genus comprises five species epithets (Index Fungorum 2018). There are no cultures and no phylogenetic analysis for Angatia species (Wijayawardene et al. 2017a). Angatia is thus treated as a doubtful genus until fresh collections with sequence data are available as no type exists.

\section{Angatia rondoniensis Bat., J.L. Bezerra \& Castr., Atas Inst. Micol. Univ. Recife 3: 65 (1966)}

Index Fungorum number: IF326199; Facesoffungi number: FoF04667

Epiphytic on leaves. Sexual morph: see notes below. Asexual morph: Undetermined.

Notes - We re-examined the specimen (URM 51224), but it was in poor condition and thus ascomata, asci and ascospores were redrawn (Fig. 55). According to the type description from Batista et al. (1966), ascomata are amphigenous, numerous, scattered, sub-discoid, 270-525 × 150$195 \mu \mathrm{m}$, globose, membranaceous to coriaceous, with dark brown epithecium, pseudoparenchymatous, 18.5-26 $\mu \mathrm{m}$ wide, composed of polygonal cells, 3-7.5 $\times 4.5-5 \mu \mathrm{m}$, basal stroma, 150-300 $\mu \mathrm{m}$ diam., context interthecial, hyaline, cellulose. Asci are ellipsoidal to cylindrical, bitunicate, subsessile, 6-8-spored, 48-66 × 18.5-22 $\mu \mathrm{m}$, in different layers and aparaphysate. Ascospores are ellipsoid, with 7 transverse septa and 1 longitudinal septum, not constricted at the septum, hyaline, polystichae and 19-22 ×6-10.5 $\mu \mathrm{m}$.

Material examined - BRAZIL, Marajá, Maranhão, on leaves of Arecaceae, 30 August 1965, G.E. Peres (URM 51224).

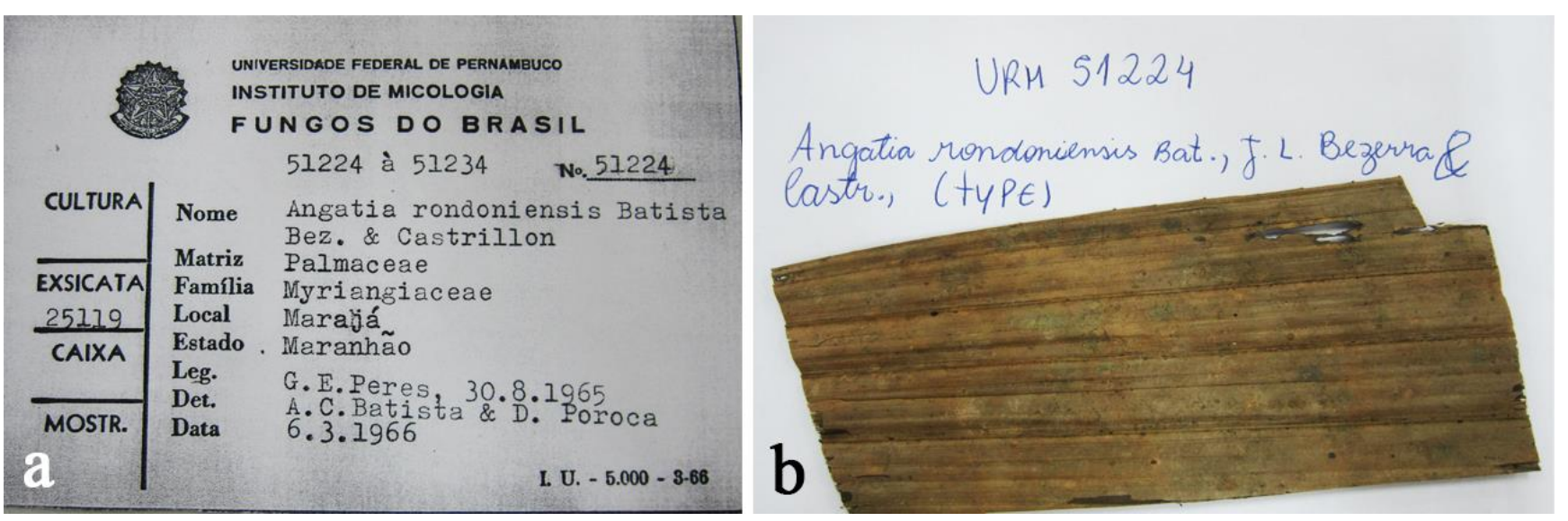

Figure 54 - Angatia rondoniensis (URM 51224). a Herbarium label. b Details of herbarium specimen with host. 


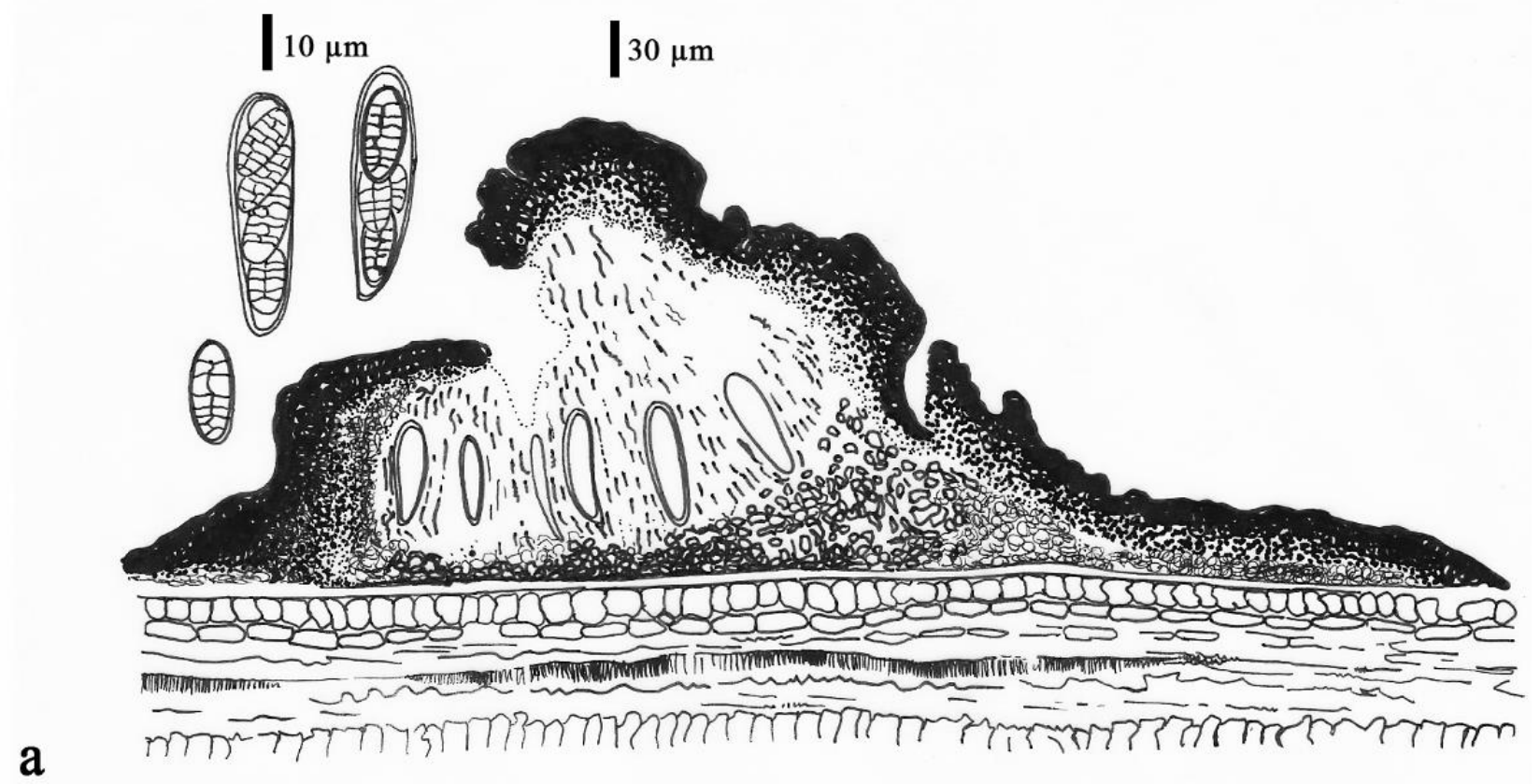

Figure 55 - Angatia rondoniensis. a Ascoma, asci and ascospores (redrawn from Batista et al. 1966; Page 79, Fig. 2). Scale bars: $\mathrm{a}=30 \mu \mathrm{m}$ for ascoma, $10 \mu \mathrm{m}$ for asci and ascospores.

\section{Acknowledgements}

M. Doilom and I. Promputtha are sincerely grateful to Chiang Mai University. We are appreciative and thankful to the curators of the various herbaria cited in the text for providing us the materials within their care. KD. Hyde would like to thank National Research Council of Thailand (Mae Fah Luang University) grant no 60201000201 entitled "Diseases of mangrove trees and maintenance of good forestry practice" and Thailand Research Fund (TRF) grant no RSA5980068 entitled "Biodiversity, phylogeny and role of fungal endophytes on above parts of Rhizophora apiculata and Nypa fruticans". JC. Xu would like to thank Key Research Program of Frontier Sciences, CAS, Grant No. QYZDY-SSW-SMC014. We gratefully thank Mrs. Anusha Hasini Ekanayaka, Mrs. Subashini Chathumini Jayasiri, Miss Dhandevi Pem and Miss Qing Tian (Mae Fah Luang University, Thailand) for kindly correcting part of their related details in the manuscript. AJL. Phillips acknowledges the support from Biosystems and Integrative Sciences Institute (BioISI, FCT/UID/ Multi/04046/2013). S. Boomee thanks to the National Research Council of Thailand (no. 61215320023) for supporting studies on taxonomic diversity and phylogeny of microfungi on palms. DQ. Dai and LZ. Tang would like to thank the Key Laboratory of Yunnan Province Universities of the Diversity and Ecological Adaptive Evolution for Animals and plants on Yun-Gui Plateau, Yunnan Province Universities of the Science and Technology Innovation Team for the exploitation and utilization of endophytes, the National Natural Science Foundation of China (No. NSFC 31760013, NSFC 31260087, NSFC 31460561) and the Scientific Research Foundation of Yunnan Provincial Department of Education (2017ZZX186) for finance support.

\section{References}

Abdel-Aziz FA, Abdel-Wahab MA. 2010 - Lolia aquatica gen. et sp. nov. (Lindgomycetaceae, Pleosporales), a new coelomycete from freshwater habitats in Egypt. Mycotaxon 114, 33-42.

Aguirre-Hudson B. 1991 - A taxonomic study of the species referred to the ascomycete genus Leptorhaphis. Bulletin of the British Museum (Natural History) 21, 85-192. 
Aguirre-Hudson B. 2009 - Leptorhaphis. In: Smith CW, Aptroot A, Coppins BJ, Fletcher A, Gilbert OL, James PW, Wolseley PA (eds.). The Lichens of Great Britain and Ireland. British Lichen Society, London, pp. 551-553.

Aguirre-Hudson B, Hawksworth DL. 1987 - The circumscription, biology and relationships of the genus Leptrorhaphis Körber. Bibl Lichenologica 25, 249-255.

Aguirre-Hudson B, Fiol L. 1993 - A new species of Leptorhaphis (Arthopyreniaceae) on Opuntia from the Balearic Islands. Lichenologist 25, 207-210.

Aguirre-Hudson B, Farkas E, Lokös L. 2002 - Pyrenolichens of the Hungarian lichen flora I. the genus Leptrorhaphis Körber. Bibl Lichenologica 82, 3-18.

Akulov OY, Hayova VP. 2016 - Immotthia atrograna (Dacampiaceae, Ascomycota), a new for Ukraine fungicolous fungus from the Carpathians. Ukrainian Botanical Journal 73, 84-89.

Aptroot A. 1995a - A monograph of Didymosphaeria. Studies in Mycology 37, 1-160.

Aptroot A. 1995b - Redisposition of some species excluded from Didymosphaeria (Ascomycotina). Nova Hedwigia 60, 325-379.

Aptroot A. 1998 - Aspects of the integration of the taxonomy of lichenized and non-lichenized pyrenocarpous ascomycetes. Lichenologist 30, 501-514.

Aptroot A. 2002a - Mycoporum. In: Nash TH III, Ryan BD, Gries C, Bungartz F (eds.) Lichen Flora of the Greater Sonoran Desert Region. I. Lichens Unlimited, Arizona State University, Tempe, Arizona, 287-288.

Aptroot A. 2002b - Tomasellia. In: Nash TH III, Ryan BD, Gries C, Bungartz F (eds.) Lichen Flora of the Greater Sonoran Desert Region. I. Lichens Unlimited, Arizona State University, Tempe, Arizona, 487-488.

Aptroot A. 2004 - Two new ascomycetes with long gelatinous appendages collected from monocots in the tropics. Studies in Mycology 50, 307-311.

Aptroot A. 2006 - Mycosphaerella and its anamorphs: 2. Conspectus of Mycosphaerella. CBS Biodiversity Series 5, 1-23.

Aptroot A, Sparrius LB. 2008 - Crustose Roccellaceae in the Galapagos Islands, with the new species Schismatomma Spierii. Bryologist 111, 659-666.

Aptroot A. 2012 - A world key to the species of Anthracothecium and Pyrenula. The Lichenologist $44,5-53$.

Aptroot A. 2014 - Two new genera of Arthoniales from New Caledonia and the Solomon Islands, with the description of eight further species. The Bryologist 117, 282-289

Aptroot A, van Iperen AL. 1998 - New ascomycetes and ascomycete records from Papua New Guinea. Nova Hedwigia 67, 481-497.

Aptroot A, Menezes AA, Xavier-Leite AB, dos Santos VM et al. 2014 - Revision of the corticolous Mazosia species, with a key to Mazosia species with 3-septate ascospores. The Lichenologist 46, 563-72.

Ariyawansa HA, Camporesi E, Thambugala KM, Mapook A et al. 2014a - Confusion surrounding Didymosphaeria - phylogenetic and morphological evidence suggest Didymosphaeriaceae is not a distinct family. Phytotaxa 176, 102-119.

Ariyawansa HA, Tanaka K, Thambugala KM, Phookamsak R et al. 2014b - A molecular phylogenetic reappraisal of the Didymosphaeriaceae (= Montagnulaceae). Fungal Diversity $68,69-104$.

Ariyawansa HA, Phukhamsakda C, Thambugala KM, Bulgakov TS et al. 2015 - Revision and phylogeny of Leptosphaeriaceae. Fungal Diversity 74, 19-51.

Atienza V, Calatayud V, Hawksworth DL. 2003 - Notes on the genus Polycoccum (Ascomycota, Dacampiaceae) in Spain, with a key to the species. - The Lichenologist 35, 125-135.

Aveskamp MM, De Gruyter J, Woudenberg JHC, Verkley GJM et al. 2010 - Highlights of the Didymellaceae: a polyphasic approach to characterise Phoma and related pleosporalean genera. Studies in Mycology 65, 1-60.

Barr ME. 1968 - The Venturiaceae in North America. Canadian Journal of Botany 46, 799-864.

Barr ME. 1975 - The genus Ostreichnion. Mycotaxon 3, 81-88. 
Barr ME 1976 - Perspectives in the Ascomycotina. Memoirs of the New York Botanical Garden 28, $1-8$.

Barr ME. 1979 - A classification of Loculoascomycetes. Mycologia 71, 935-957.

Barr ME. 1982 - On the Pleomassariaceae (Pleosporales) in North America. Mycotaxon 15, 345348.

Barr ME. 1983 - The ascomycete connection. Mycologia 75, 1-13.

Barr ME. 1987a - New taxa and combinations in the Loculoascomycetes. Mycotaxon 29, 501-505.

Barr ME. 1987b - Prodromus to class Loculoascomycetes. Published by the author, Amherst.

Barr ME. 1987c - Teichosporaceae, another family in the Pleosporales. Mycotaxon 82, 382-383.

Barr ME. 1990 - Melanommatales (Loculoascomycetes). North American Flora. Series II Part 13, $1-129$.

Barr ME. 1993 - Redisposition of some taxa described by J.B. Ellis. Mycotaxon 46, 45-76.

Barr ME. 2002 - Teichosporaceae, another family in the Pleosporales. Mycotaxon 82, 373-389.

Barr ME, Blackwell M. 1980 - A new genus in the Lophiaceae. Mycologia 72, 1224-1227.

Batista AC, Ciferri R. 1963 - Capnodiales. Saccardoa 2, 1-298.

Batista AC, Bezerra JL. 1964 - Polystomellaceae: novas entidades Brasileiras. Portugaliae Acta Biologica 7(4), 361-382.

Batista AC, Bezerra JL, Castrillon AL, Silva AA et al. 1966 - Allosoma arrabideae n. sp. e outros Myriangiaceae. Atas do Instituto de Micologia da Universidade do Recife 3, 62-83.

Bensch K, Braun U, Groenewald JZ, Crous PW. 2012 - The genus Cladosporium. Studies in Mycology 72, 1-401.

Bensch K, Groenewald JZ, Braun U, Dijksterhuis J et al. 2015 - Common but different: The expanding realm of Cladosporium. Studies in Mycology 82, 23-74.

Bhattacharya D, Lutzoni F, Reeb V, Simon D, Nason J, Fernandez F. 2000 - Widespread occurrence of spliceosomal introns in the rDNA genes of ascomycetes. Molecular Biology and Evolution 17, 1971-1984.

Blackwell M, Gilbertson RL. 1985 - Quasiconcha reticulata and its anamorph from conifer roots. Mycologia 77, 50-54.

Boehm EWA, Schoch CL, Spatafora JW 2009a- On the evolution of the Hysteriaceae and Mytilinidiaceae (Pleosporomycetidae, Dothideomycetes, Ascomycota) using four nuclear genes. Mycological Research 113, 461-479.

Boehm EWA, Mugambi GK, Miller AN, Huhndorf SMet al. 2009b- A molecular phylogenetic reappraisal of the Hysteriaceae, Mytilinidiaceae and Gloniaceae (Pleosporomycetidae, Dothideomycetes) with keys to world species. Studies in Mycology 64, 49-83.

Boise JR. 1987 - Mycopepon, a new ascomycete genus. Systema Ascomycetum 6, 167-170.

Boise JR. 1994 - Pseudovalsa smithii is an earlier name for Mycopepon guianensis. Mycotaxon 52, 303.

Brackel WV, Berger F. 2010 - Gall-inducing species of Polycoccum (Ascomycota) on the lichen genus Placopsis. Herzogia 23, 195-204.

Braun U, Crous PW, Dugan F, Groenewald JZ, Hoog GS de. 2003 - Phylogeny and taxonomy of Cladosporium-like hyphomycetes, including Davidiella gen. nov., the teleomorph of Cladosporium s. str. Mycological Progress 2, 3-18.

Cannon PF, Kirk PM. 2007 - Fungal Families of the World. Wallingford, UK: CABI. 1-456.

Câmara MPS, Palm ME, Berkum P van, O'Neill NR. 2002 - Molecular phylogeny of Leptosphaeria and Phaeosphaeria. Mycologia 94, 630-640.

Chen Q, Zhang K, Zhang GZ, Cai L. 2015 - A polyphasic approach to characterize two novel species of Phoma (Didymellaceae) from China. Phytotaxa 197, 267-281.

Chen Q, Hou LW, Duan WJ, Crous PW, Cai L. 2017 - Didymellaceae revisited. Studies in Mycology 87, 105-159

Chevallier FF. 1826 - Flore Générale des Environs de Paris 1, 1-674.

Clements FE. 1909 - The Genera of Fungi. HW Wilson Co. Publ., Minneapolis, MN, U.S.A. 
Clements FE, Shear CL. 1931 - Genera of fungi, edn 2. i-vii, 58 plates. H.W. Wilson Company, USA, New York, p 496.

Cooke MC. 1878 - Ravenel's American fungi. Grevillea 7, 43-54.

Cooke MC. 1883 - North American fungi. Grevillea 11, 106-111.

Coppins BJ, Kondratyuk SY. 1995 - Stygiomyces and Pseudonitschkia: two new genera of lichenicolous fungi. Edinburgh Journal of Botany 52, 229-236.

Coppins BJ, Orange A. 2009 - Arthopyrenia. In: Smith CW, Aptroot A, Coppins BJ, Fletcher A, Gilbert OL, James PW, Wolseley PA (eds.) The Lichens of Great Britain and Ireland. British Lichen Society, London, 171-176.

Crous PW, Barreto RW, Alfenas AC, Alfenas RF, Groenewald JZ. 2010 - What is Johansonia?. IMA Fungus 1, 117-122.

Crous PW, Wingfield MJ, Guarro J, Cheewangkoon R et al 2013 - Fungal planet description sheets: 154-213. Persoonia 31, 188-296.

Daranagama DA, Hyde KD, Sir EB, Thambugala KM et al. 2018 - Towards a natural classification and backbone tree for Graphostromataceae, Hypoxylaceae, Lopadostomataceae and Xylariaceae. Fungal Diversity 88, 1-165.

Dayarathne MC, Phookamsak R, Ariyawansa HA, Jones EBG et al. 2015 - Phylogenetic and morphological appraisal of Leptosphaeria italica sp. nov. (Leptosphaeriaceae, Pleosporales) from Italy. Mycosphere 6, 634-642.

Dayarathne MC, Boonmee S, Braun U, Crous PW et al. 2016 - Taxonomic utility of old names in current fungal classification and nomenclature: Conflicts, confusion \& clarifications. Mycosphere 7, 1622-1648.

De Gruyter J, Aveskamp MM, Woudenberg JHC, Verkley GJM et al. 2009 - Molecular phylogeny of Phoma and allied anamorph genera: Towards a reclassification of the Phoma complex. Mycological Research 113, 508-519.

De Gruyter J, Woudenberg JHC, Aveskamp MM, Verkley GJM et al. 2013 - Redisposition of phoma-like anamorphs in Pleosporales. Studies in Mycology 75, 1-36.

De Notaris G. 1844 - Cenno sulla tribu de'pirenomiceti sferiacei e descrizione di alcuni nuovi generi. Giorn. Bot. Ital. 1, 322-335.

De Notaris G. 1847 - Prime linee di una nuova disposizione dei Pirenomiceti Isterini. Giornale Botanico Italiano 2, part I, fasc 7-8, 5-52.

Döbbeler P. 1980 - Phycorella scytonematis (Dothideales), ein neuer Symbiont der Blaualge Scytonema. Sydowia 33, 33-38.

Duby JE. 1862 - Memoire sur la tribu des Hysterinees de la famille des Hypoxylees (Pyrenomycetes). Memoires de la Société de physique et d'histoire naturelle de Genève. 16, $15-70$.

Ekanayaka AH, Ariyawansa HA, Hyde KD, Jones EBG et al. 2017 - DISCOMYCETES: the apothecial representatives of the phylum Ascomycota. Fungal Diversity 87, 237-298.

Eriksson OE. 1981 - The families of bitunicate ascomycetes. Opera Botanica 60, 1-220.

Eriksson OE. 2006 - Outline of Ascomycota. Myconet 12, 1-88.

Eriksson OE. Hawksworth DL. 1986 - Outline of the Ascomycetes - 1986. Systema Ascomycetum $5,185-324$.

Eriksson OE, Hawksworth DL. 1998 - Outline of the ascomycetes -1998. Systema Ascomycetum $16,83-296$.

Ertz D, Tehler A, Eberhard F, Dorothee K et al. 2014a - Isalonactis, a new genus of Roccellaceae (Arthoniales), from southern Madagascar. Lichenologist 46, 159-167.

Ertz D, Lawrey JD, Common RS, Diederich P. 2014b - Molecular data resolve a new order of Arthoniomycetes sister to the primarily lichenized Arthoniales and composed of black yeasts, lichenicolous and rock-inhabiting species. Fungal Diversity 66, 113-137.

Ertz D, Diederich P, Lawrey JD, Berger F et al. 2015a - Phylogenetic insights resolve Dacampiaceae (Pleosporales) as polyphyletic: Didymocyrtis (Pleosporales, 
Phaeosphaeriaceae) with Phoma-like anamorphs resurrected and segregated from Polycoccum (Trypetheliales, Polycoccaceae fam. nov.). Fungal Diversity 74, 53-89.

Ertz D, Tehler A, Irestedt M, Frisch A et al. 2015b - A large-scale phylogenetic revision of Roccellaceae (Arthoniales) reveals eight new genera. Fungal Diversity 70, 31-53.

Follmann G, Werner BC. 2003 - Lichenicolous fungi occurring on Roccellaceae (Arthoniales) I. New species from south America. Journal of the Hattori Botanical Laboratory 116, 261-292.

Fries EM. 1815 - Observationes mycologicae 1, 1-230.

Fries EM. 1823 - Systema Mycologicum. Lund 2, 583.

Fuckel L. 1870 - Symbolae mycologicae. Beiträge zur Kenntniss der Rheinischen Pilze. Jahrbücher des Nassauischen Vereins für Naturkunde 23-24, 1-459.

Gardiennet A. 2012 - Découverte de Polycoccum slaptoniense D. Hawksw. en France. - Bulletin d'Informations de l'Association Francaise de Lichénologie 37, 107-111.

Gäumann EA. 1949 - Die Pilze, Grundzüge ihrer Entwicklungsgeschichte und Morphologie. Birkhäuser. Basel.

Guatimosim E, Pinto HJ, Barreto RW, Prado J. 2014 - Rhagadolobiopsis, a new genus of Parmulariaceae from Brazil with a description of the ontogeny of its ascomata. Mycologia 106, 276-281.

Guatimosim E, Firmino AL, Bezerra JL, Pereira OL, Barreto RW. 2015 - Towards a phylogenetic reappraisal of Parmulariaceae and Asterinaceae (Dothideomycetes). Persoonia 35, 230 - 241.

Hafellner J. 2015 - Distributional and other data for some species of Didymocyrtis (Dothideomycetes, Pleosporales, Phaeosphaeriaceae), including their Phoma-type anamorphs. Fritschiana 80, 43-88.

Halıc1 MG. 2010 - Weddellomyces pertusariicola (Ascomycota, Dacampiaceae), a new species growing on Pertusaria lactea in Turkey. Annales Botanici Fennici 47, 148-150.

Halici MG, Akgül HE, Öztürk C, Kiliç E. 2013 - Polycoccum anatolicum sp. nov. on Lepraria incana and a key to Polycoccum species known from Turkey. Mycotaxon 124, 45-50.

Harris RC. 1973 - The corticolous pyrenolichens of the Great Lakes Region. The Michigan Botanist 12, 3-68.

Harris RC. 1975 - A Taxonomic Revision of the Genus Arthopyrenia Massal. s. lat. (Ascomycetes) in North America. Doctoral thesis, Michigan State University.

Harris RC. 1995 - More Florida Lichens. Including the 10ф Tour of the Pyrenolichens. Publ. by the Author, Bronx.

Hawksworth DL. 1977 - Three new genera of lichenicolous fungi. Botanical Journal of the Linnean Society. 75, 195-209.

Hawksworth DL. 1979 - Ascospore sculpturing and generic concepts in the Testudinaceae (syn. Zopfiaceae). Canadian Journal of Botany 57, 91-99.

Hawksworth DL. 1980 - Notes on some fungi occurring on Peltigera, with a key to accepted species. Transactions of the British Mycological Society 74, 363-386.

Hawksworth DL. 1983 - The identity of Pyrenidium actinellum Nyl. Transactions of the British Mycological Society 80, 547-549.

Hawksworth DL. 1989 - Jarxia, a new genus of Didymosphaeria-like fungi from the West Indies. Studies in Mycology 31, 93-97.

Hawksworth DL, Diederich P. 1988 - A synopsis of the genus Polycoccum (Dothideales), with a key to accepted species. Transactions of the British Mycological Society 90, 293-312.

Hawksworth DL, Kirsop BE, Jong SC. 1988 -Filamentous Fungi. Cambridge University Press.

Hibbett DS, Binder M, Bischoff JF, Blackwell M et al. 2007 - A higher-level phylogenetic classification of the Fungi. Mycological Research 111, 509-547.

Hirayama K, Tanaka K, Raja HA, Miller AN, Shearer CA. 2010 - A molecular phylogenetic assessment of Massarina ingoldiana sensu lato. Mycologia 102, 729-746.

Holm L, Holm K. 1988 - Studies in the Lophiostmataceae with emphasis on the Swedish species. Symbolae Botanicae Upsalienses 28, 1-50. 
Hongsanan S, Li YM, Liu JK, Hofmann T et al. 2014 - Revision of genera in Asterinales. Fungal Diversity 68, 1-68.

Hongsanan S, Tian Q, Peršoh D, Zeng XY et al. 2015 - Meliolales. Fungal Diversity 74, 91-141.

Hongsanan S, Maharachchikumbura SS, Hyde KD, Samarakoon MC et al. 2017a - An updated phylogeny of Sordariomycetes based on phylogenetic and molecular clock evidence. Fungal Diversity 84, 25-41.

Hongsanan S, Zhao RL, Hyde KD. 2017b - A new species of Chaetothyrina on branches of mango, and introducing Phaeothecoidiellaceae fam. nov. Mycosphere 8, 137-146.

Howard DH. 1983 - Pathogenic fungi in humans and animals. Marcel Dekker, Inc. New York.

Howard DH. (Ed.). 2002 - Pathogenic fungi in humans and animals. CRC Press.

Höhnel F von. 1909a - Fragmente zur Mykologie: VI. Mitteilung (Nr. 182 bis 288). Sitzungsberichte der Kaiserlichen Akademie der Wissenschaften Math.-naturw. Klasse Abt. I $118,275-452$.

Höhnel F von. 1909b - Fragmente zur Mykologie: VIII. Mitteilung (Nr. 354 bis 406). Sitzungsberichte der Kaiserlichen Akademie der Wissenschaften Math.-naturw. Klasse Abt. I 118, 1157-1246.

Höhnel F von. 1918 - Mycologische Fragmente, 272. Über die Hysteriaceen. Annales Mycologici $16,145-154$.

Hu H. 2010 - Morphological and molecular studies of selected Dothideomycetes. Ph.D. thesis, Southwest Forestry University, The University of Hong Kong.

Hyde KD. 1989 - Intertidal mangrove fungi from north Sumatra. Canadian Journal of Botany 67, 3078-3082.

Hyde KD. 1993 - Tropical Australian freshwater fungi. VI*. Tiarosporella paludosa and Clohesyomyces aquaticus gen. et sp. nov. (Coelomycetes). Australian Systematic Botany 6, 169-173.

Hyde KD. 1991 - A new amphisphaeriaceous fungus from intertidal fronds of Nypa fruticans. Transactions of the Mycological Society of Japan 32, 265-267.

Hyde KD, Jones EBG. 1989 - Marine fungi from Seychelles. VIII. Rhizophila marina, a new ascomycete from mangrove prop roots. Mycotaxon 34, 528.

Hyde KD, Wong WSW, Aptroot A. 2002 - Marine and estuarine species of Lophiostoma and Massarina. In: Fungi in Marine Environments (Hyde KD, ed.). Fungal Diversity Research Series 7, 93-109.

Hyde KD, McKenzie EHC, KoKo TW. 2011 - Towards incorporating anamorphic fungi in a natural classification checklist and notes for 2010. Mycosphere 2, 1-88.

Hyde KD, Jones EBG, Liu JK, Ariyawansa H et al. 2013 - Families of Dothideomycetes. Fungal Diversity 63, 1-313.

Hyde KD, Hongsanan S, Jeewon R, Bhat DJ et al. 2016 - Fungal Diversity notes 367-490: taxonomic and phylogenetic contributions to fungal taxa. Fungal Diversity 80, 1-270.

Hyde KD, Norphanphoun C, Abreu VP, Bazzicalupo A et al. 2017 - Fungal diversity notes 603708: taxonomic and phylogenetic notes on genera and species. Fungal Diversity 87, 1-235.

Hyde KD, Chaiwan N, Norphanphoun C, Boonmee S et al. 2018 - Mycosphere notes 169-224. Mycosphere 9, 271-430.

Ibrahim M. 2014 - Diversität endophytischer Blatt-Pilze auf Fraxinus ornus. MSc thesis, ETH Zurich, Zurich

Ibrahim M, Schlegel M, Sieber TN. 2016 - Venturia orni sp. nov., a species distinct from Venturia fraxini, living in the leaves of Fraxinus ornus. Mycological Progress 15, 1-29.

Inácio CA, Araúz K, Piepenbring M. 2012 - A new genus of Parmulariaceae from Panama. Mycological Progress 11, 1-6.

Index Fungorum. 2018 - http://www.indexfungorum.org/Names/Names.asp

Jaklitsch WM, Scheuer C. 2002 - Notes on the genus Immotthia (Pleosporales, Ascomycetes), including some type studies. Österreichische Mykologische Gesellschaft, 93-106. 
Jaklitsch WM, Fournier J, Dai DQ, Hyde KD, Voglmayr H. 2015 - Valsaria and the Valsariales. Fungal Diversity 73, 159-202.

Jaklitsch W, Baral HO, Lücking R, Lumbsch HT, Frey W. 2016 -Ascomycota. In: Frey W (ed) Syllabus of plant families, Adolf Engler's Syllabus der Pflanzenfamilien $13^{\text {th }}$ edn. Borntraeger Science Publishers, Stuttgart.

Jayasiri SC, Hyde KD, Ariyawansa HA, Bhat DJ et al. 2015 - The faces of fungi database: fungal names linked with morphology, phylogeny and human impacts. Fungal Diversity 74, 3-18.

Jayasiri SC, Hyde KD, Jones EBG, Jeewon R et al. 2017 - Taxonomy and multigene phylogenetic evaluation of novel species in Boeremia and Epicoccum with new records of Ascochyta and Didymella (Didymellaceae). Mycosphere 8, 1080-1101.

Jayasiri SC, Hyde KD, Jones EBG, Persoh D et al. 2018 - Taxonomic novelties of hysteriform Dothideomycetes. Mycosphere (in press).

Kalb K, Hafellner J, Staiger B. 1995 - Haematomma-Studien II. Lichenicole Pilze auf Arten der Flechtengattung Haematomma. Bibl Lichenologica 59, 199-222.

Kirk PM, Cannon PF, David JC, Stalpers JA. 2001 - Ainsworth \& Bisby's dictionary of the fungi, 9th edn. CABI, Wallingford.

Kirk PM, Cannon PF, Minter DW, Stalpers JA. 2008 - Ainsworth \& Bisby's dictionary of the fungi, 10th edn. CABI, Wallingford.

Knapp DG, Kovács GM, Zajta E, Groenewald JZ, Crous PW. 2015 - Dark septate endophytic pleosporalean genera from semiarid areas. Persoonia 35, 87-100.

Knudsen K, Kocourková J. 2010 - Pyrenidium aggregatum, a new species from North America. Opuscula Philolichenum 8, 71-74.

Kodsueb R, Dhanasekaran V, Aptroot A, Lumyong S et al. 2006a - The family Pleosporaceae: intergeneric relationships and phylogenetic perspectives based on sequences analyses of partial 28S rDNA. Mycologia 98, 571-583.

Kodsueb R, Jeewon R, Vijaykrishna D, McKenzie EHC et al. 2006b - Systematic revision of Tubeufiaceae based on morphological and molecular data. Fungal Diversity 21, 105-130.

Kohlmeyer J, Volkmann-Kohlmeyer B, Eriksson OE. 1998 - Fungi on Juncus roemerianus. 11. More new ascomycetes. Canadian journal of botany 76, 467-477.

Körber GW. 1860 -Ergänzungen zum Systema lichenum Germaniae. Parerga lichenologica. 97192.

Körber GW. 1865 - Ergänzungen zum Systema lichenum Germaniae. Parerga lichenologica. (Breslau), 385-501.

Kruys Å, Eriksson OE, Wedin M. 2006 - Phylogenetic relationships of coprophilous Pleosporales (Dothideomycetes, Ascomycota), and the classification of some bitunicate taxa of unknown position. Mycological Research 110, 527-536.

Lawrey JD, Diederich P. 2015 - Lichenicolous fungi - worldwide checklist, including isolated cultures and sequences available. - URL: http://www.lichenicolous.net [version 10/10/2015].

Li GJ, Hyde KD, Zhao RL, Hongsanan et al. 2016 - Fungal diversity notes 253-366: taxonomic and phylogenetic contributions to fungal taxa. Fungal Diversity 78, 1-237.

Liew ECY, Aptroot A, Hyde KD. 2000 - Phylogenetic significance of the pseudoparaphyses in Loculoascomycete taxonomy. Molecular Phylogeny \& Evolution 16, 392-402.

Liu JK, Phookamsak R, Jones EBG, Zhang Y et al. 2011 - Astrosphaeriella is polyphyletic, with species in Fissuroma gen. nov., and Neoastrosphaeriella gen. nov. Fungal Diversity 51, 135 154.

Liu JK, Phookamsak R, Dai DQ, Tanaka K et al. 2014 - Roussoellaceae, a new pleosporalean family to accommodate the genera Neoroussoella gen. nov., Roussoella and Roussoellopsis. Phytotaxa 181, 1-33.

Liu JK, Hyde KD, Jones EBG, Ariyawansa HA et al. 2015 - Fungal diversity notes 1-110: taxonomic and phylogenetic contributions to fungal species. Fungal Diversity 72, 1-197.

Liu JK, Hyde KD, Jeewon R, Phillips AJ et al. 2017 - Ranking higher taxa using divergence times: a case study in Dothideomycetes. Fungal Diversity 84, 75-99. 
Lumbsch HT, Huhndorf SM. (eds) 2007 - Outline of Ascomycota - 2007. Myconet 13, 1-58.

Lumbsch HT, Huhndorf SM. 2010 - Myconet Volume 14. Part one. Outline of Ascomycota 2009. Part Two. Notes on Ascomycete Systematics. Nos. 4751-5113. Fieldiana Life Earth Science $1,1-64$.

Luttrell ES. 1973 - Loculoascomycetes. In: Ainsworth GC, Sparrow FK, Sussman AS (eds.) The Fungi IV A. Academic Press, New York, 135-219.

Lutzoni F, Kauff F, Cox CJ, McLaughlin D et al. 2004 - Assembling the fungal tree of life: progress, classification, and evolution of subcellular traits. American Journal of Botany 91, $1446-1480$.

Lücking R. 2008 - Foliicolous lichenized fungi. Flora Neotropica Monograph 103, 1-866.

Lücking R, Hodkinson BP, Leavitt SD. 2016 - The 2016 classification of lichenized fungi in the Ascomycota and Basidiomycota-Approaching one thousand genera. The Bryologist 119, 361-416.

Maharachchikumbura SS, Hyde KD, Jones EBG, McKenzie EHC et al. 2015 - Towards a natural classification and backbone tree for Sordariomycetes. Fungal Diversity 72, 199-301.

Maharachchikumbura SSN, Hyde KD, Jones EBG, McKenzie EHC et al. 2016 - Families of Sordariomycetes. Fungal Diversity 79, 1-317.

Massalongo AB. 1854 - Neagenea lichenum, 1-10.

Massalongo AB. 1856 - Genera lichenum aliquot nova proponit et describit A.B.D. Prof. Massalongo. Flora (Regensburg) 39, 281-286.

Matzer M. 1996 - Lichenicolous Ascomycetes with Fissitunicate Asci on Foliicolous Lichens. Mycological Papers 171. CAB International: Wallingford. 202 pp.

Miadlikowska J, Kauff F, Högnabba F, Oliver JC et al. 2014 - A multigene phylogenetic synthesis for the class Lecanoromycetes (Ascomycota): 1307 fungi representing 1139 infrageneric taxa, 317 genera and 66 families. Molecular Phylogenetics \& Evolution 79, 132-168.

Mugambi GK, Huhndorf SM. 2009 - Molecular phylogenetics of Pleosporales: Melanommataceae and Lophiostomataceae re-circumscribed (Pleosporomycetidae, Dothideomycetes, Ascomycota). Studies in Mycology 64, 103-121.

Munk A. 1953 - The system of the pyrenomycetes. A contribution to avnatural classification of the group Sphaeriales sensu Lindau. Dansk Botanisk Arkiv 15, 1-163.

Mühlenberg G. 1813 - Cont. Lab. Plant Disease Science Faculty, Agricultural Gifu University. 101.

Müller E, von Arx JA. 1962 - Die Gattungen der didymosporen Pyrenomyceten. Beitrage zur Kryptogamenflora der Schweiz 11, 1-992.

Müller E. 1963 - Epibelonium, eine neue Gattung der Schizothyriaceen (Ascomyceten). Phytopathologische Zeitschrift 47, 239-243.

Nannfeldt JA. 1932 - Studien über die Morphologie und Systematik der nichtlichenisierten, inoperkulaten Discomyceten. Nova Acta Regiae Societatis Scientiarum Uppsaliensis IV 8, 1368.

Navarro-Rosinés P, Roux Cl. 2007 - Pyrenidium Nyl. (1865). In: Lichen Flora of the Greater Sonoran Desert Region. Vol. 2. (eds TH Nash III, BD Ryan, P Diederich, C Gried, F Bungartz). Lichens Unlimited, Arizona State University, Tempe, Arizona 404-405.

Nylander W. 1865 - Novitatiae quaedum lichenum europaeorum variarum tribuum. Flora (Regensburg) 48, 209-213.

Nylander W. 1873 - Lichenes insularum Andaman. Bulletin de la Société Linnéenne de Normandie. 7, 162-182.

Nylander W. 1886 - Addenda nova ad lichenographiam europaeam. Contin. XLVI. Flora (Regensburg). 69, 461-466.

Parguey-Leduc A. 1970 - Un genre nouveau du Pyrenomycete ascoloculaire: le g. lepidosphaeria. Comptes rendus hebdomadaires des séances de l'Académie des sciences. 270, 2786. 
Perdomo H, García D, Gené J, Cano J et al. 2013 - Phialemoniopsis, a new genus of Sordariomycetes, and new species of Phialemonium and Lecythophora. Mycologia 105, 398421.

Phillips AJL, Alves A, Correia A, Luque J. 2005 - Two new species of Botryosphaeria with brown, 1-septate ascospores and Dothiorella anamorphs. Mycologia 97, 513-529.

Phillips AJL, Alves A, Abdollahzadeh J, Slippers B et al. 2013 - The Botrysphaeriaceae: genera and species known from culture. Studies in Mycology 76, 51-167.

Phookamsak R, Liu JK, McKenzie EHC, Manamgoda DS et al. 2014 - Revision of Phaeosphaeriaceae. Fungal Diversity 68, 159-238.

Phookamsak R, Norphanphoun C, Tanaka K, Dai DQ et al. 2015 - Towards a natural classification of Astrosphaeriella-like species; introducing Astrosphaeriellaceae and Pseudoastrosphaeriellaceae fam. nov. and Astrosphaeriellopsis, gen. nov. Fungal Diversity 74, 143-197.

Phookamsak R, Boonmee S, Norphanphoun C, Wanasinghe DN et al. 2016 - Schizothyriaceae. Mycosphere 7, 154-189.

Pilsczek FH, Augenbraun M. 2007 - Mycetoma fungal infection: multiple organisms as colonizers or pathogens?. Revista da Sociedade Brasileira de Medicina Tropical 40, 463-465.

Pinnoi A, Jeewon R, Sakayaroj J, Hyde KD, Jones EBG. 2007 - Berkleasmium crunisia sp. nov. and its phylogenetic affinities to the Pleosporales based on 18S and 28S rDNA sequence analyses. Mycologia 99, 378-384.

Pirogov MV. 2015 - Clypeococcum cetrariae (Dacampiaceae, Ascomycota) in the Ukrainian Carpathians. Ukrayins'kyi Botanichnyi Zhurnal 72, 585-587.

Pirozynski KA. 1973 - Three hyperparasites of ascomycetes. Mycologia 65, 761-767.

Pitt WM, Úrbez-Torres JR, Trouillas FP. 2014 - Munkovalsaria donacina from grapevines and Desert Ash in Australia. Mycosphere 5, 656-661.

Raja HA, Tanaka K, Hirayama K, Miller AN, Shearer CA. 2011 - Freshwater ascomycetes: two new species of Lindgomyces (Lindgomycetaceae, Pleosporales, Dothideomycetes) from Japan and USA. Mycologia 103, 1421-1432.

Raja HA, Oberlies NH, El-Elimat T, Miller AN et al. 2013 - Lindgomyces angustiascus, (Lindgomycetaceae, Pleosporales, Dothideomycetes), a new lignicolous species from freshwater habitats in the USA. Mycoscience 54, 353-361.

Ramaley AW. 1995 - New fungi from Dasylirion (Agavaceae). Aliso. 14, 147-153.

Reeb V, Lutzoni F, Roux C. 2004 - Contribution of RPB2 to multilocus phylogenetic studies of the euascomycetes (Pezizomycotina, Fungi) with special emphasis on the lichen-forming Acarosporaceae and evolution of polyspory. Molecular phylogenetics and evolution 32, 1036-1060.

Réblová M. 2007 - Barbatosphaeria gen. et comb. nov., a new genus for Calosphaeria barbirostris. Mycologia 99, 723-732.

Réblová M, Stepanek V. 2009 - New fungal genera, Tectonidula gen. nov. for Calosphaeria-like fungi with holoblastic-denticulate conidiogenesis and Natantiella gen. nov. for three species segregated from Ceratostomella. Mycological Research 113, 991-1002.

Réblová M, Réblová K, Štěpánek V. 2015 - Molecular systematics of Barbatosphaeria (Sordariomycetes): multigene phylogeny and secondary ITS structure. Persoonia 35, 21-38.

Rehm H. 1886 - Revision der Hysterineen in herb. Duby. Hedwigia 25, 137-155, 173-202.

Reynolds DR, Gilbert GS. 2005 - Epifoliar fungi from Queensland, Australia. Australian Systematic Botany 18, 265-289.

Rouxel T, Balesdent MH. 2005 - The stem canker (blackleg) fungus, Leptosphaeria maculans, enters the genomic era. Molecular Plant Pathology 6, 225-241.

Sanderson NA, Coppins BJ. 2009a - Mycoporum. In: Smith CW, Aptroot A, Coppins BJ, Fletcher A, Gilbert OL, James PW, Wolseley PA (eds.) The Lichens of Great Britain and Ireland. British Lichen Society, London, 620-622. 
Sanderson NA, Coppins BJ. 2009b - Tomasellia. In: Smith CW, Aptroot A, Coppins BJ, Fletcher A, Gilbert OL, James PW, Wolseley PA (eds.) The Lichens of Great Britain and Ireland. British Lichen Society, London, 894-895.

Santesson R. 1960 - Lichenicolous fungi from northern Spain. - Svensk Botanisk Tidskrift 54, 499-522.

Saccardo PA. 1882 - Sylloge Fungorum. 1, Padova, 1-768.

Saccardo PA. 1883 - Sylloge Fungorum. 2, Italy, Patavii, 1-815.

Sakata A, Harada H, Yoshikawa H. 2017 - Taxonomic study on the lichen family Roccellaceae (Arthoniales) of Japan (5). Two new corticolous species of Mazosia. Lichenology 16, 31-47.

San Martín FE. 1996 - Una nueva variedad de Mycopepon smithii (Ascomycetes, Pleosporales). Acta Botanica Mexicana 35, 9-12.

Sarma VV, Hyde KD, Vittal BPR. 2001 - Frequency of occurrence of mangrove fungi from the east coast of India. Hydrobiologia 455, 41-53.

Schoch CL, Shoemaker RA, Seifert KA, Hambleton S et al. 2006 - A multigene phylogeny of the Dothideomycetes using four nuclear loci. Mycologia 98, 1041-1052.

Schoch CL, Crous PW, Groenewald JZ, Boehm EWA et al. 2009 - A class-wide phylogenetic assessment of Dothideomycetes. Studies in Mycology 64, 1-15.

Scholtysik A, Unterseher M, Otto P, Wirth C. 2013 - Spatio-temporal dynamics of endophyte diversity in the canopy of European ash (Fraxinus excelsior). Mycological Progress 12, 291304.

Senanayake IC, Maharachchikumbura SSN, Hyde KD, Bhat JD et al. 2015 - Towards unraveling relationships in Xylariomycetidae (Sordariomycetes). Fungal Diversity 73, 73-144.

Segretain G, Destombes P. 1961 - Description d'un nouvel agent de maduromycose, Neotestudina rosatii, n. gen., n. sp., isolé en Afrique. Comptes Rendues des Scéances de l'Académie des Sciences. 253, 2577-2579.

Shearer CA, Crane JL. 1980 - Taxonomy of two cleistothecial ascomycetes with apilionaceous ascospores. Transactions of the British Mycological Society 75, 193-200.

Shearer C, Hyde KD. 1997 - Massarina ingoldiana, a new ascomycete from freshwater habitats. Mycologia 89, 114-119.

Shearer CA, Raja HA, Miller AN, Nelson P et al. 2009 - The molecular phylogeny of freshwater Dothideomycetes. Studies in Mycology 64, 145-153.

Shen M, Zhang JQ, Zhang Y. 2016 - Venturia species form sooty mold-like colonies on leaves of Salix: introducing Venturia fuliginosa sp. nov. Mycosphere 7, 1292-1300.

Silva AA, Cavalcante WA, Leal FB. 1973 - Um novo gênero da família Schizothyriaceae, em Leguminosae. Publicações do Instituto de Micologia da Universidade do Recife. 691, 1-16.

Sivanesan A. 1977. The taxonomy and pathology of Venturia species. Lubrecht \& Cramer Ltd, Vaduz.

Sivanesan A. 1984 - The bitunicate ascomycetes and their anamorphs. J. Cramer, Vaduz. 701 pp.

Smith CL. 1893 - Some Central American Pyrenomycetes. Bulletin from the Laboratories of Natural History of the State University of Iowa 2, 394-415.

Sokolova O, Morocko-Bicevska I, Bankina B. 2014 - Review of the pear scab caused by Venturia pyrina. Research for Rural Development 1, 26-33.

Sparrius LB. 2004 - A monograph of Enterographa and Sclerophyton. Bibliotheca Lichenologica $89,1-141$.

Spatafora JW, Owensby CA, Douhan GW, Boehm EWA, Schoch CL. 2012 - Phylogenetic placement of the ectomycorrhizal genus Cenococcum in Gloniaceae (Dothideomycetes). Mycologia 104, 758-765.

Suetrong S, Schoch CL, Spatafora JW, Kohlmeyer J et al. 2009 - Molecular systematics of the marine Dothideomycetes. Studies in Mycology 64, 155-173.

Swinscow TDV. 1965 - Pyrenocarpous Lichens 9. Lichenologist 3, 72-83. 
Sydow H, Sydow P, Butler E. 1911 - Fungi indiae orientalis II. Microthyriaceae. Annales Mycologici 9, 389-392.

Sydow H, Sydow P. 1914 - Diagnosen neuer philippinischer Pilze. Annales Mycologici 12, 566567.

Tian Q, Hongsanan S, Dai DQ, Alias SA et al. 2016 - Towards a natural classification of Dothideomycetes: clarification of Aldona, Aldonata and Viegasella (Parmulariaceae). Mycosphere 7, 511-524.

Tibpromma S, Hyde KD, Jeewon R, Maharachchikumbura SSN et al. 2017 - Fungal diversity notes 491-602: taxonomic and phylogenetic contributions to fungal taxa. Fungal Diversity 83, $1-$ 261.

Tanaka K, Harada Y. 2003 - Pleosporales in Japan (1): the genus Lophiostoma. Mycoscience 44, 85-96.

Taylor JW. 2015 - Evolutionary perspectives on human fungal pathogens. Cold Spring Harbor Perspectives in Medicine 5, 1-18.

Tehler A. 1990 - A new approach to the phylogeny of Euascomycetes with a cladistic outline of Arthoniales focussing on Roccellaceae. Canadian Journal of Botany 68, 2458-2492.

Tehler A, Dahlkild A, Eldenäs P, Feige GB 2004 - The phylogeny and taxonomy of Macaronesian, European and Mediterranean Roccella (Roccellaceae, Arthoniales). Symbolae Botanicae Upsalienses 34, 405-428.

Tehler A, Ertz D, Irestedt M. 2007 - Parallel evolution of lichen growth forms in the family Roccellaceae (Arthoniales, Ascomycota). Cladistics-the International Journal of the Willi Hennig Society 23, 432-454.

Tehler A, Irestedt M, Bungartz F, Wedin M. 2009 - Evolution and reproduction modes in the Roccella galapagoensis aggregate (Roccellaceae, Arthoniales). Taxon 58, 438-456.

Tehler A, Irestedt M, Wedin M, Ertz D. 2010 - The Old World Roccella species outside Europe and Macaronesia: taxonomy, evolution and phylogeny. Systematics \& Biodiversity 8, 223246.

Tehler A, Irestedt DEM. 2013 - The genus Dirina (Roccellaceae, Arthoniales) revisited. Lichenologist 45, 427-476.

Tennakoon DS, Hyde KD, Wanasinghe DN, Bahkali AH et al. 2016 - Taxonomy and phylogenetic appraisal of Montagnula jonesii sp. nov. (Didymosphaeriaceae, Pleosporales). Mycosphere 7, 1346-1356.

Thambugala KM, Hyde KD, Tanaka K, Tian Q et al. 2015 - Towards a natural classification and backbone tree for Lophiostomataceae, Floricolaceae, and Amorosiaceae fam. nov. Fungal Diversity 74, 199-266.

Thambugala KM, Hyde KD, Eungwanichayapant PD, Romero AI, Liu ZY. 2016 - Additions to the genus Rhytidhysteron in Hysteriaceae. Cryptogam Mycol 37, 99-116.

Theissen F. 1913a - Die Gattung Asterina in systematischer Darstellung. Abhandlungen der Zoologisch-Botanischen Gesellschaft Wien. 7, 1-130.

Theissen F. 1913b - Über einige Mikrothyriaceen. Annales Mycologici 11, 493-511.

Tsang CC, Chan JFW, Trendell-Smith NJ, Ngan AHY et al. 2014 - Subcutaneous phaeohyphomycosis in a patient with IgG4-related sclerosing disease caused by a novel ascomycete, Hongkongmyces pedis gen. et sp. nov.: first report of human infection associated with the family Lindgomycetaceae. Medical Mycology 52, 736-747.

Vaillancourt LJ, Hartman JR. 2000 - Apple scab. The Plant Health Instructor. DOI: 10.1094/PHI-I2000-1005-01 Updated 2005.

https://www.apsnet.org/edcenter/intropp /lessons/fungi/ascomycetes/Pages/AppleScab.aspx

Vainio EA. 1921 - Lichenographia Fennica I. - Pyrenolichenes iisque proximi Pyrenomycetes et Lichenes imperfecti. - Acta Societatis pro Fauna et Flora Fennica. 49, 1-274.

Van den Broeck D, Luecking R, Ertz D. 2014 - The foliicolous lichen biota of the Democratic Republic of the Congo, with the description of six new species. The Lichenologist 46, 141158. 
Van der Aa HA. 1971 - Macroventuria, a new genus of the Venturiaceae. Persoonia 6, 359-363.

Viégas AP. 1944 - Alguns fungos do Brazil. II. Ascomicetos. Bragantia 4, 1-392.

von Arx JA. 1963 - DieGattungen der Myriangiales. Persoonia 2, 421-475.

von Arx JA, Müller E. 1975 - A re-evaluation of the bitunicate ascomycetes with keys to families and genera. Studies in Mycology 9, 1-159.

Wanasinghe DN, Camporesi E, Hu DM. 2016a - Neoleptosphaeria jonesii sp. nov., a novel saprobic sexual species, in Leptosphaeriaceae. Mycosphere 7, 1368-1377.

Wanasinghe DN, Jones EBG, Camporesi E, Dissanayake AJ et al. 2016b - Taxonomy and phylogeny of Laburnicola gen. nov. and Paramassariosphaeria gen. nov. (Didymosphaeriaceae, Massarineae, Pleosporales). Fungal Biology 120, 1354-1373.

Wanasinghe DN, Jeewon R, Tibpromma S, Jones EBG, Hyde KD 2017 - Saprobic Dothideomycetes in Thailand: Muritestudina gen. et sp. nov. (Testudinaceae) a new terrestrial pleosporalean ascomycete, with hyaline and muriform ascospores. Studies in Fungi 2, 219 234.

Wanasinghe DN, Phukhamsakda C, Hyde KD, Jeewon R et al. 2018 - Fungal diversity notes 709839: taxonomic and phylogenetic contributions to fungal taxa with an emphasis on fungi on Rosaceae. Fungal Diversity 89, 1-236.

Wang HK, Aptroot A, Crous PW, Hyde KD, Jeewon R. 2007 - The polyphyletic nature of Pleosporales: an example from Massariosphaeria based on rDNA and RBP2 gene phylogenies. Mycological Research 111, 1268-1276.

Ward NA. 2012 - Apple scab. Plant Pathology Fact Sheet.

Wijayawardene NN, Crous PW, Kirk PM, Hawksworth DL et al. 2014 - Naming and outline of Dothideomycetes - 2014 including proposals for the protection or suppression of generic names. Fungal Diversity 69, 1-55.

Wijayawardene NN, Hyde KD, Rajeshkumar KC, Hawksworth DL et al. 2017a - Notes for genera: Ascomycota. Fungal Diversity 86, 1-594.

Wijayawardene NN, Hyde KD, Tibpromma S, Wanasinghe DN et al. 2017b - Towards incorporating asexual fungi in a natural classification: checklist and notes 2012-2016. Mycosphere 8, 1457-1554.

Wijayawardene NN, Hyde KD, Lumbsch HT, Liu JK et al. 2018 - Outline of Ascomycota: 2017. Fungal Diversity 88, 167-263.

Winter G. 1885 - Pilze-Ascomyceten. In: GL Rabenhorst's Kryptogamen-Flora von Deutschland, Oesterreich und der Schweiz 1, 65-528.

Winton LM, Stone JK, Hansen EM, Shoemaker RA. 2007 - The systematic position of Phaeocryptopus gaeumannii. Mycologia 99, 240-252.

Yang H, Sun G, Batzer J, Crous P et al. 2010 - Novel fungal genera and species associated with the sooty blotch and flyspeck complex on apple in China and the USA. Persoonia 24, 29-37.

Zeng XY, Hongsanan S, Hyde KD, Chomnunti P, Wen TC. 2018 - Translucidithyrium thailandicum gen. et sp. nov., a new genus in Phaeothecoidiellaceae. Mycological Progress (in press).

Zhang H, Dong W, Hyde KD, Maharachchikumbura SSN et al. 2017 - Towards a natural classification of Annulatascaceae-like taxa: introducing Atractosporales ord. nov. and six new families. Fungal Diversity 85, 75-110.

Zhang J, Dou Z, Zhou Y, He W et al. 2016 - Venturia chinensis sp. nov., a new venturialean ascomycete from Khingan Mountains. Saudi Journal of Biological Sciences 23, 592-597.

Zhang Y, Fournier J, Crous PW, Pointing SB, Hyde KD. 2009a - Phylogenetic and morphological assessment of two new species of Amniculicola and their allies (Pleosporales). Persoonia 23, $48-54$.

Zhang Y, Schoch CL, Fournier J, Crous PW et al. 2009b - Multi-locus phylogeny of the Pleosporales: a taxonomic, ecological and evolutionary reevaluation. Studies in Mycology 64, 85-102. 
Zhang Y, Crous PW, Schoch CL, Bahkali AH et al. 2011 - A molecular, morphological and ecological re-appraisal of Venturiales -a new order of Dothideomycetes. Fungal Diversity 51, 249-277.

Zhang Y, Crous PW, Schoch CL, Hyde KD. 2012 - Pleosporales. Fungal Diversity 53, 1-221.

Zhurbenko M. 2010 - Lichenicolous fungi and lichens growing on Stereocaulon from the Holarctic, with a key to the known species. Opusc Philolichenum 8, 9-39.

Zhurbenko M, Dillman KL. 2010 - Polycoccum hymeniicola comb. nov. (Dacampiaceae) and other interesting lichenicolous fungi from southeastern Alaska. Bryologist 113, 260-266.

Zogg H. 1960 - Über die Gattungen Actidium Fries und Bulliardella (Saec.) Paoli. Berichte der Schweizerischen Botanischen Gesellschaft 70, 195-205.

Zogg H. 1962 - Die Hysteriaceae s. str. und Lophiaceae, unter besonderer Berücksichtigung der mitteleuropäischen Formen. Beiträge zur Kryptogamenflora der Schweiz, Band 11, 1-190. 